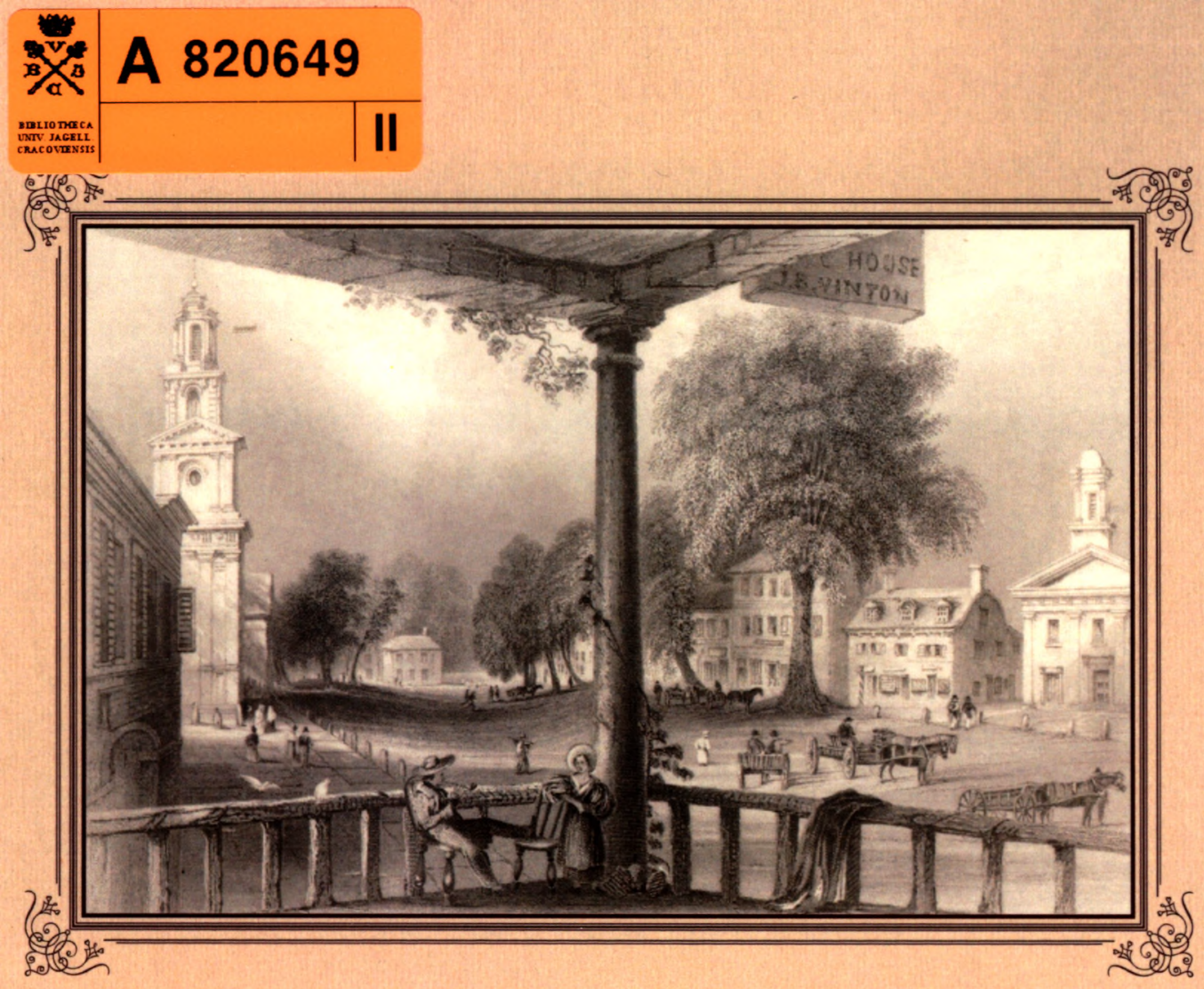

Ewa Modzelewska

Fugust Antoni Jakubowski

- poeta rozpaczy

$\infty$

Życie i twórczość 

AUGUST ANTONI JAKUBOWSKI - POETA ROZPACZY

ŻYCIE I TWÓRCZOŚĆ 


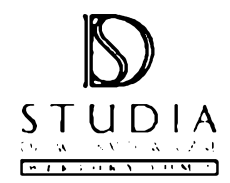

W serii Studia dziewiętnastowieczne. Wektory ukazały się:

Podróże i podróżopisarstwo w polskiej literaturze $i$ kulturze XIX wieku. Studia i szkice, red. A. Kowalczyk, A. Kwiatek, Kraków 2015. 
Ewa Modzelewska

\section{August Antoni Jakubowski - poeta rozpaczy \\ Życie i twórczość}

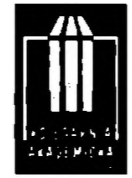

Kraków 
(c) Copyright by Ewa Modzelewska, Kraków 2015

Redakcja naukowa serii:

Boguslaw Dopart

Recenzenci:

prof. dr hab. Boguslaw Dopart

dr hab. Agnieszka Ziolowicz, prof. UJ

Opracowanie redakcyjne:

Anna Stokłosa

Projekt okładki:

Emilia Dajnowicz

Sklad:

Józef Paluch

Na okładce wykorzystano grafikę z 1839 roku przedstawiającą miasteczko

Northampton, sprowadzoną z Muzeum Historycznego w Northampton

Książka dofinansowana przez Towarzystwo Doktorantów Uniwersytetu Jagiellońskiego

ISBN 978-83-7638-550-1

e-ISBN 978-83-7638-613-3

KSIĘGARNIA AKADEMICKA

ul. św. Anny 6, 31-008 Kraków

tel./faks: 124312743,124211387

e-mail: akademicka@akademicka.pl 


\section{Spis treści}

Wstęp

I. Stan badań dotyczących życia i twórczości Augusta Antoniego

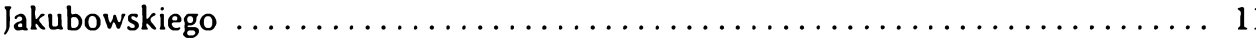

1. Pierwsze wzmianki o Auguście Antonim Jakubowskim ............. 11

2. Krajowe i zagraniczne echa odkrycia wierszy Jakubowskiego ........... 14

3. Nowe ustalenia dotyczące Augusta Antoniego Jakubowskiego .......... 17

II. August Antoni Jakubowski - biografia poety rozpaczy $\ldots \ldots \ldots \ldots \ldots \ldots \ldots 35$

III. Poezje Augusta Antoniego Jakubowskiego . . . . . . . . . . . . . . . 47

1. „Pamiętnik duszy” Jakubowskiego odnaleziony po 132 latach . ......... 47

2. „U mnie nie róża - u mnie kolor czarny”, czyli o pierwszych próbach poetyckich Jakubowskiego ........................... 50

3. „Serca mego uczta się skończyła” - utwory więzienne syna

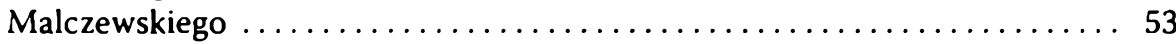

4. „To morze będzie moim grobem i siedliskiem" - utwory akwatyczne

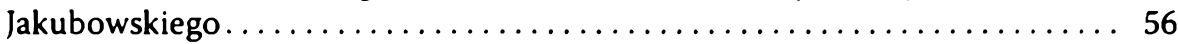

5. Novum w polskiej poezji - Indianin i Indianka ............... 57

6. „Gdzież jest miła moja dola, kiedym dumał wśród Podola?” - poezja

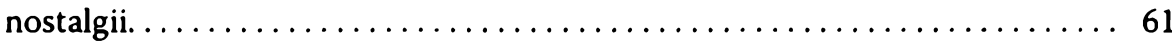

7. „I już więcej nie pomarzę i już więcej nie polecę” - dojrzewanie do śmierci .......................................63

8. The Exile's Song i It is weary - nieznane amerykańskie wiersze Jakubowskiego..................................... 69

9. Julia R. Bowers - amerykańska muza Jakubowskiego? . . . . . . . . . . 77

IV. The Remembrances of a Polish Exile - pierwsza próba syntezy polskich dziejów i antologia ojczystej poezji w Ameryce.

1. Dzieło znamionujace geniusza. Zarys i budowa The Remembrances of a Polish Exile...

2. Such was and such is our poetry, czyli esej o polskiej poezji ........... 87

3. Nation with heroic feelings and spirit, czyli o narodzie polskim, którego ducha nie można złamać.

4. Such was the fate of the Polish Lovers $w$ autorskim opowiadaniu Jakubowskiego.

5. The Remembrances of a Polish Exile jako manifest polityczny 
V. Major Aleksander - niepublikowana powieść Augusta Antoniego

Jakubowskiego

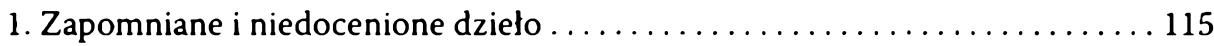

2. Autobiografizm Majora Aleksandra ......................... 118

3. Echa Marii w Majorze Aleksandrze............................ 119

4. Kwestie genologiczne Majora Aleksandra ..................... 124

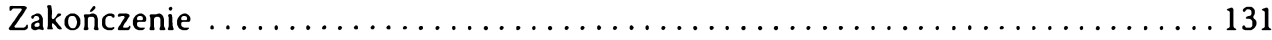

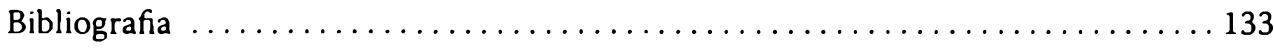

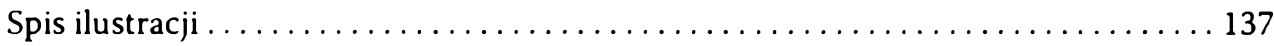

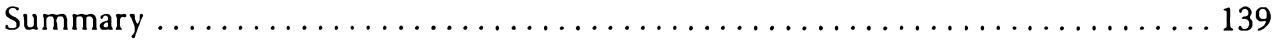

Indeks osobowy...................................... 141 


\section{Wstęp}

W obcej ziemi gdzieś skończę życie me tułacze,

Grób mój nie będzie między groby podolskimi,

Dusza tylko w ojczyźnie, choć proch w obcej ziemi

(...) me imie

Wkrótce tu zapomniane nikogo nie wzruszy

[A. A. Jakubowski, Tutacz]

Bogusław Dopart pisał, że śmierć prawdziwie „zazdrośnym palcem” ścierała ślady żywota autora Marii ${ }^{1}$. Jednak jeszcze okrutniej obeszła się z synem Malczewskiego. Przeczucie wczesnej śmierci i zupełnego zapomnienia prześladowało Augusta Antoniego Jakubowskiego, nieślubnego syna Antoniego Malczewskiego, niemal od początku jego twórczości. Rzeczywiście, do tej pory jego burzliwe, zakończone samobójstwem 21-letnie życie, rozpięte między dwoma kontynentami, zawierało więcej zagadek i tajemnic niż potwierdzonych faktów.

Poezje Jakubowskiego, zebrane w 1839 roku i przygotowane do wydania przez współtowarzysza wygnania do Ameryki, Marcina Rosienkiewicza, przez 132 lata leżały zagrzebane w archiwach Biblioteki Polskiej w Paryżu. Dopiero w 1971 roku odnalazł je Julian Maślanka i dwa lata później opublikował ich zawartość. Mimo to twórczość młodzieńca nie doczekała się swojej monografii. A przecież Jakubowski zapisał się w historii nie tylko jako syn wielkiego poety, ale przede wszystkim jako autor pierwszej publikacji o Polsce w Ameryce, będącej przy tym miniaturową antologią polskiej poezji romantycznej. Doktor William Buell Sprague, opiekun Jakubowskiego w Stanach Zjednoczonych, stwierdzil, że jest to dzieto znamionujące geniusza. August Antoni napisał je po angielsku po zaledwie dziesięciu miesiącach nauki obcego mu wcześniej języka, nie mając dostępu do żadnych pomocy naukowych. Wzbogacił on również polską poezję o oryginalne wiersze inspirowane amerykańskim folklorem, zupełnie wyjątkowe na tle dotychczasowej literatury.

Nazwany przez Seweryna Goszczyńskiego „młodzieńcem pięknej nadziei”2 zostawił po sobie 42 utwory liryczne, wpisujące się w nurt „czarnego romantyzmu", będące krzykiem straconego pokolenia, przeniknięte bólem istnienia $\mathrm{i}$ jeszcze większym pesymizmem niż poemat jego ojca. Lektura poetyckiego dorobku

' B. D o p a r t, Romantyzm polski. Pluralizm prądów i synkretyzm dzieła, Kraków 1999, s. 9.

${ }^{2}$ S. Goszcz yń ski, Wstęp. [w:] A. Malc ze ws ki, Maria, Lipsk 1844, s. 37. 
Jakubowskiego, w tym właśnie zacytowanego Tułacza, gdzie pada wyznanie: me imię/ wkrótce tu zapomniane nikogo nie wzruszy ${ }^{3}$, poruszyła mnie i sprawiła, że postanowiłam zbadać tajemnice jego biografii oraz twórczości. Swoje poszukiwania prowadziłam w rękopiśmiennych zbiorach bibliotek: Naukowej Polskiej Akademii Umiejętności i Polskiej Akademii Nauk, Jagiellońskiej, a także Książąt Czartoryskich. Rozszerzyłam je również poza Polskę - sprowadziłam materiały źródłowe z Biblioteki Polskiej w Paryżu, Harvardu oraz Northampton, gdzie August Antoni jako nauczyciel spędził ostatnie lata życia.

Miałam niezwykłe szczęście odnaleźć na „obcej ziemi”, będącej miejscem wygnania Jakubowskiego, mecenasa Przemysława Jana Blocha, założyciela Fundacji Rodzinnej Blochów zajmującej się restytucją przedmiotów związanych z polskim dziedzictwem narodowym, utraconych po pierwszym rozbiorze Polski. Okazało się, że Przemysław Bloch również interesuje się amerykańskimi losami Augusta Antoniego, a w imponujących zbiorach swojej fundacji posiada wszystkie dotychczasowe oryginalne XIX-wieczne wydania The Remembraces of a Polish Exile, $w$ tym te dotąd nieznane badaczom. Kiedy napisałam do niego $z$ informacją, że przygotowuję książkę na temat życia i twórczości syna Malczewskiego, szybko dostałam odpowiedź: „Bardzo się cieszę, że młodemu pokoleniu nie jest zupełnie obca postać Augusta Antoniego Jakubowskiego. Czas ku temu najwyższy".

Dzięki jego pomocy, życzliwości i bibliofilskiej pasji udało się znaleźć odpowiedzi na pytania, których nie mogli udzielić dotychczasowi badacze tematu. Zdobyte przez niego wyciągi aktów zgonów z Northampton pozwoliły ustalić prawdopodobną datę urodzin Jakubowskiego, a dokumenty uzyskane w Muzeum Historycznym w Northampton oraz inne materiały rozstrzygnęly wiele wątpliwości z biografii młodego wygnańca. Nowojorski adwokat osobiście odnalazł i zaopiekował się grobem Augusta Antoniego znajdującym się w Bridge Street Cemetery w Northampton, gdzie Jakubowski pracował jako nauczyciel języka francuskiego w prestiżowym Gothic Seminary. Fotografie wykonane przez mecenasa Blocha, a także plan cmentarza zostały umieszczone $w$ aneksie. Teraz przy małym nagrobku polskiego wygnańca stojącym na uboczu, przy samym ogrodzeniu, powiewają biało-czerwone chorągiewki, a co jakiś czas pojawiają się świeże kwiaty - dowody pamięci i szacunku rodaków, których Jakubowski prawdopodobnie nigdy by się nie spodziewał.

Mecenas Bloch udostępnił mi również zawartość wszystkich edycji The $R e$ membrances... ze swojej kolekcji, co pozwoliło na zbadanie i przeanalizowanie występujących w nich różnic. W trakcie moich badań okazało się, że na ostatnich stronach niezwykle rzadkiego wydania z 1836 roku znajdują się dwa niepublikowane wcześniej i nieomawiane do tej pory wiersze Jakubowskiego - The Exile's Song oraz It is weary. Fundacja Blochów posiada także w swoich zbiorach tomik z 1835 roku zawierający dedykację Kościałkowskiego dla jednej z uczennic Jakubowskiego - Lucy Dewey oraz wklejony na tylnej okładce wiersz-epitafium Podo- 
lia's Exiled Child, napisany kobiecą ręką i podpisany przez jej koleżankę z klasy - Julię Bowers. Ten wzruszający utwór autorstwa najprawdopodobniej zakochanej w Jakubowskim dziewczyny koresponduje z jego twórczością i pozwala przypuszczać, że wiersz poety Do J.B. był pisany z myślą właśnie o niej. Na przedniej okładce omawianego egzemplarza widnieją brunatne plamy, które zidentyfikowano jako ślady krwi. Nowojorski adwokat przypuszcza, że mogą one należeć do Jakubowskiego. Hipoteza ta rzuca nowe światło na przyczynę samobójstwa syna Malczewskiego związaną z nieszczęśliwą miłością.

Niniejsza książka stanowi próbę stworzenia pierwszej monografii twórczości Augusta Antoniego Jakubowskiego. Powstała ona w oparciu o teksty źródłowe, w tym sprowadzoną z Biblioteki Polskiej w Paryżu kopię rękopisu Pism pośmiertnych poety w opracowaniu Marcina Rosienkiewicza. Materiały te zostały poddane analizie edytorskiej, a przede wszystkim pozwoliły mi zbadać niepublikowany dotąd fragment prozy Jakubowskiego zatytułowany Major Aleksander, a napisany już w Ameryce.

Praca ta rozpoczyna się od omówienia stanu dotychczasowych badań nad twórczością i biografią Jakubowskiego, zestawiając zarówno polskie, jak i zagraniczne źródła wzmiankujące o synu Malczewskiego. W pierwszej kolejności usystematyzuję dorobek poetycki Jakubowskiego, następnie dokonam jego podziału na poszczególne etapy, przyporządkowując do nich utwory. Zadanie to jest tym trudniejsze, że tylko niektóre z nich są datowane. Dodatkowe komplikacje wynikają z faktu, że nie dysponujemy oryginalnymi rękopisami syna Malczewskiego, a jedynie odpisami sporządzonymi przez Marcina Rosienkiewicza, byłego nauczyciela Liceum Krzemienieckiego i współwygnańca do Ameryki, który w 1839 roku postanowił ocalić od zapomnienia twórczość przyjaciela. Badania rękopisu pozwoliły ustalić, że pierwotnie Pisma pośmiertne Jakubowskiego prezentowały inny układ utworów niż ten przedstawiony w Poezjach wydanych przez Juliana Maślankę, co także stało się przedmiotem badań w niniejszej książce. Dokonam również ich analizy, szczegółowo omawiając topikę, metaforykę oraz obrazowanie występujące najczęściej w liryce młodego wygnańca.

$\mathrm{Z}$ kolei $\mathrm{w}$ rozdziale poświęconym The Remembrances of a Polish Exile, przetłumaczonym na język polski dopiero w 2013 roku, przybliżę zarys i budowę wszystkich części dzieła: zarówno dedykację Jakubowskiego, jego przedmowę i uwagi wstępne doktora Sprague'a, jak i kolejne jego części: Essay on a Polish Poetry, Historical Sketch of Education in Poland, The Polish Lovers, The Causes of the Emigration of the Poles oraz Appendix containing a short notice of Ukraine and Podolia ${ }^{4}$. August Antoni wszystkie te informacje zawarł na 70 stronach książeczki niewielkiego formatu, przedstawiając je w niezwykle syntetyczny sposób. W każdym rozdziale ukazywał Amerykanom tragiczne losy bohaterskiego narodu, który został zniewolony przez zaborców. Wspomnienia polskiego wygnańca

1 Thumaczenie: Esej o polskiej poezji, Historyczny szkic o edukacji w Polsce, Polscy Kochankowie, Przyczyny emigracji Polaków, Dodatek zawierający krótkq wzmiankę o Ukrainie i Podolu. 
są świadectwem nie tylko wykształcenia, erudycji, zainteresowań i lektur syna Malczewskiego, ale również szczerej miłości do ojczyzny i chęci przedstawienia za granicą jej najcenniejszych wartości. Książka ta miała doniosłe znaczenie polityczne i ugruntowała sławę młodego wygnańca jako polskiego poety w Stanach Zjednoczonych Ameryki.

Na zakończenie zaprezentuję niedocenione i zapomniane dzieło Jakubowskiego, napisane z myślą o amerykańskim czytelniku, które znajduje się w rękopisie Pism pośmiertnych, ale nigdy nie zostało wydane. Aby dopełnić obraz twórczości Augusta Antoniego, sprowadziłam kopię wspomnianego rękopisu znajdującego się w Bibliotece Polskiej w Paryżu i dokonałam transkrypcji fragmentu prozy zatytułowanego Major Aleksander, a pochodzącego z Pism pośmiertnych Jakubowskiego w edycji Rosienkiewicza. W niniejszej książce omówię ten niezwykły utwór, jego zadziwiające paralele z Mariq Antoniego Malczewskiego, a także liczne wątki autobiograficzne w nim ukryte.

Do tej pory nikt nie postawił też konkretnej hipotezy dotyczącej tożsamości matki młodego wygnańca, gdyż nie znano nawet daty urodzin poety. W świetle odkryć pochodzących ze „śledztwa” prowadzonego razem z Bogusławem Dopartem na potrzeby tej pracy wydaje się bardzo prawdopodobne, że była nią księżna Franciszka Maria Lubomirska z domu Załuska. Ponadto, dzięki analizie filologicznej, dorobek literacki Jakubowskiego został hipotetycznie poszerzony o nowy, niezidentyfikowany dotąd utwór poety Tell me, tell me, little tree, znajdujący się w The Remembrances of a Polish Exile.

Badacze dotychczas zajmujący się spuścizną Augusta Antoniego są zgodni, że zapowiadał się on na poetę wysokiej klasy. Cudem powróciwszy z "wygnania”, po ponad 130 latach twórczość Jakubowskiego doczekała się kilku recenzji i znowu popadła w zapomnienie. Dopiero po 2000 roku Jarosław Ławski przypomina dorobek literacki syna Malczewskiego, przybliżając jego główne wyznaczniki i wartości. Utwory Jakubowskiego, podobnie jak jego życie, wpisują się w pewien fatalistyczny porządek, od którego cały czas próbował się uwolnić. Poeta „pięknej nadziei", który bezskutecznie usiłował znaleźć swoje miejsce w życiu, zasługuje, aby przynajmniej jego twórczość zajęła należne jej miejsce w historii literatury polskiej.

Przy pisaniu niniejszej książki inspirację czerpałam z dzieł Jarosława Ławskiego oraz z pionierskiej pracy Juliana Maślanki ${ }^{5}$, odkrywcy poezji Jakubowskiego. To właśnie dzięki jego dziełu dowiedziałam się o istnieniu syna Malczewskiego i zafascynowałam się twórczością "poety rozpaczy”. 


\section{Stan badań dotyczących życia i twórczości Augusta Antoniego Jakubowskiego}

Celem niniejszego rozdziału jest przedstawienie dotychczasowego stanu wiedzy na temat życia i twórczości Augusta Antoniego Jakubowskiego, a także nowych, nigdy dotąd niepublikowanych informacji o synu Malczewskiego. Są one efektem moich poszukiwań i współpracy z Biblioteką Polską w Paryżu, Muzeum Historycznym w Northampton, a także z Uniwersytetem Harvarda przy nieocenionej pomocy mecenasa Przemysława Jana Blocha, znanego polskiego bibliofila, filantropa i darczyńcy mieszkającego w Nowym Jorku.

Jak wspomniałam, poeta-wygnaniec nie doczekał się jeszcze swojej monografii, a informacje o nim są rozsiane po różnych źródłach. Niniejszy rozdział stanowi próbę zestawienia materiałów dotyczących Jakubowskiego, które ukazały się w kraju i za granicą oraz zbadania recepcji jego twórczości.

\section{Pierwsze wzmianki o Auguście Antonim Jakubowskim}

Pierwszą znaną polską wzmianką o Jakubowskim był jego nekrolog opublikowany 10 września 1838 roku w 25 numerze paryskiego pisma emigracyjnego „Młoda Polska”. Został on przesłany redakcji przez Marcina Rosienkiewicza, który postanowił wydać dzieła Augusta Antoniego pośmiertnie. W nekrologu tym czytamy:

W miasteczku Northampton w Stanach Zjednoczonych umart dn. 25 kwiet. 1837 r. August Antoni Jakubowski, młodzieniec peten zdolności, rodem z Podola. W przeciagu roku tyle byt postapit $w$ jezzyku angielskim, że byt $w$ stanie pisać nim proza $i$ wierszem. Wydat ksiazieczkę "The Remembrances of a Polish Exile". Jako próbe jego jeszcze mitodego, petnego naleciatości talentu, umieszczamy tu wiersz: „Dwie gwiazdki".

Przygotowywane przez Rosienkiewicza wydanie pism Jakubowskiego nie doszło do skutku, a zatem wiersz Dwie gwiazdki jest pierwszą opublikowaną w języku polskim próbą poetycką syna Malczewskiego. To właśnie on poruszył sześć lat

' M. Rosienkiewic z, [Nekrolog A. A Jakubowskiego], „Mloda Polska” 1838, nr 25, s. 294. 
później Seweryna Goszczyńskiego, który we wstępie do lipskiego wydania Marii z 1844 roku napisał:

Nie możemy właściwiej zakończyć tego pisma, jak zapisaniem jeszcze jednego szczegótu, mało komu dotąd wiadomego. Malczewski zostawit syna z pobocznego toża; ten potomek Malczewskiego, nazwiskiem Jakubowski, majac udziat w ostatnich walkach narodu, podzielit także losy jego części powotanej do cierpienia poza krajem i zamieszkat w Ameryce. Jakkolwiek bardzo jeszcze mtody, zapowiadat $w$ sobie niepowszednie zdolności poetyckie; mieliśmy tego poświadczenie w kilku wierszach ogłoszonych przez pewien dziennik. Mały ten utwór pełen był głębokiego smutku i szczerego, ale smutniejsze jeszcze byto przeczucie, które w duszy obudzat. Jakoż w samej rzeczy młodzieniec tak pięknej nadziei już dzisiaj nie żyje; kilka tylko boleśnych śpiewów pozostało nam z niego. Może kiedyś naród ujrzy je obok zagrzebanych dotad w ukryciu poezyj Malczewskiego?

Prawie 100 lat upłynęło od tamtej chwili, aż Jakubowski doczekał się wspomnienia w Polsce. Stało się to za sprawą Stanisława Pigonia, który w latach 30. XX wieku przygotowywał wydanie Listów Goszczyńskiego. Zainspirowany wstępem do wydania Marii rozpoczął poszukiwania, chcąc choć częściowo wyjaśnić zagadkę syna Malczewskiego, który według badacza „zapowiadał się jako indywidualność wybitna”. W 1930 roku na łamach „Ruchu Literackiego" Pigoń powoływał się na Bibliografię Estreichera, w której odnalazł informację, że August Antoni był profesorem języka francuskiego w Albany i że wydał The Remembrances of a Polish Exile oraz w 1837 roku Dzieje literatur stowiańskich. Poza tym Pigoń wyróżnił "drobne wspominki emigracyjne" , do których zaliczał Almanach historique de l'Emigration Polonais autorstwa Krosnowskiego. Możemy tam przeczytać o Jakubowskim: chez son oncle col. d'art. au Mexique ${ }^{10}$. Później dodano jeszcze sprostowanie, że syn Malczewskiego zmarł w Bostonie. Do tej uwagi odwołał się także Potrykowski, autor Martyrologium polskiego obejmującego lata 1832-1854. Był to trzytomowy wykaz alfabetyczny emigrantów polskich wraz z notami biograficznymi. W rękopisie tego dzieła znajdującym się w Bibliotece Książąt Czartoryskich na stronie 271 czytamy:

Jakubowski Augustyn

Rodem z Królestwa Kongresowego.

Umart w Ameryce w Meksyku (podtug Krosnowskiego w Bostonie) u swego stryja, który byt

putkownikiem Artylerii w Meksyku - umart w 1836".

T. Goszcz yń ski, Wstęp, s. 37.

* S. Pigo ń, Syn Malczewskiego, „Ruch Literacki” 1930, nr 3, s. 75.

${ }^{y}$ Ibidem, s. 76.

11 A. K ros nowski, Almanach historique de l'Emigration Polonais, Paris 1837, s. 135.

$"$ J. Pot r y kow ski, Martyrologium polskie 1832-1854, rękopis z Biblioteki Książąt Czartoryskich, sygn. 53511, s. 271. 
W spisie tym nie figurują przyjaciele młodego poety, tacy jak Marcin Rosienkiewicz, Paweł Sobolewski czy Napoleon Kościałkowski. To, co wyróżnia notę Jakubowskiego od innych zapisów, to wyraźna luka pomiędzy pierwszym stwierdzeniem a kolejnym, jak gdyby autor zamierzał ją zapełnić bliższymi informacjami. Niestety, żadna $z$ nich nie jest prawdziwa, począwszy od imienia poety, miejsca urodzenia oraz miejsca i daty śmierci, a także stopnia wojskowego jego stryja, który był wówczas podpułkownikiem wojsk inżynieryjnych.

Wymienione wyżej informacje wyczerpują źródła, do jakich dotarł Stanisław Pigoń, który dokładnie przestudiował emigracyjne piśmiennictwo. Opierając się na tych wiadomościach, nie mógł zrekonstruować kompletnej biografii oraz omówić twórczości Jakubowskiego. Dlatego też zakończenie tekstu Pigonia zamienia się $\mathrm{w}$ apel wzywający badaczy do poszukiwania zaginionych dzieł młodego poety za granicą. Rękawicę podjął Julian Krzyżanowski, który jeszcze w tym samym roku odnalazł w British Museum The Remembrances of a Polish Exile w filadelfijskiej edycji wydawnictwa C. Sherman \& Co. Printers z 1835 roku. Dzieło to było próbą przybliżenia amerykańskiemu czytelnikowi historii, a przede wszystkim literatury i kultury polskiej. Jakubowski, opierając się głównie na swojej wiedzy i pamięci, stworzył jedną z pierwszych antologii poezji ojczystej w języku angielskim.

Krzyżanowski jeszcze w Londynie w czerwcu 1930 roku napisał artykuł pt. A. A. Jakubowski, syn Malczewskiego, opublikowany w „Silva Rerum”. Przeprowadził w nim krótką analizę dzieła Jakubowskiego. Na podstawie przedmowy protektora poety doktora Sprague'a oraz rozdziału The Causes of the emigration in Poland postawił hipotezy dotyczące daty narodzin Jakubowskiego oraz innych faktów z jego życia. Wybitny historyk literatury, opisując swoje wrażenia po zapoznaniu się z zawartością dzieła, przytoczył słowa amerykańskiego opiekuna Augusta Antoniego:

Muszę wyznać otwarcie, że przebiegajac karty jego ksiązki, czułem ogarniajace mnie zdumienie, że dziewiętnastoletni młodzieniec, który przed dziesięciu miesiacami nie umial niemal ani stowa po angielsku i który nie mial zadnych materiatów prócz wtasnej pamięci i wyobraźni, zdobyt się na takie okazy poezji angielskiej i prozy polskiej, jak to, co ksiazieczka ta zawiera ${ }^{12}$.

Krzyżanowski nazwal The Remembrances... zjawiskiem bardzo ciekawym, ukazującym sylwetkę entuzjasty-romantyka, który jednak nie uniknął „gładkich, a dość pustych ogólników"13.

Właściwe poszukiwania dotyczące twórczości Jakubowskiego uwieńczył Julian Maślanka, który, będąc na stypendium naukowym we Francji w 1971 roku, odnalazł w Bibliotece Polskiej w Paryżu zapomniany rękopiśmienny tomik dzieł Jakubowskiego, nigdy dotąd nieopublikowany. Nareszcie po ponad 130 latach Poe-

12 J. Krz yża now ski, $A$. A. Jakubowski, [w:] i de m, W świecie romantycznym, Kraków 1961, s. 255, Biblioteka Studiów Literackich. Pierwodruk: „Silva Rerum” R. V, 1930, 2. 8/9, s. 134-137.

is Ibidem, s. 256. 
zje znalazły swojego wydawcę. Rękopis ten składał się z 42 wierszy Jakubowskiego przepisanych ręką Rosienkiewicza. Jego autorstwa była również Wiadomość biograficzna o Jakubowskim - pierwsza obszerna i - w porównaniu z wcześniejszymi wzmiankami - kompletna biografia poety. Zawierała ona m.in. informacje o tym, że Jakubowski urodził się na Podolu i był uczniem Liceum Krzemienieckiego. Matkę, „którą nad życie ubóstwiał”, miał poznać w 10. roku życia, a ojca na krótko przed jego śmiercią.

Ze względu na młody wiek poeta prawdopodobnie nie mógł wziąć czynnego udziału w powstaniu listopadowym. Po jego upadku udał się do Galicji, gdzie został aresztowany i zesłany przez rząd austriacki do Ameryki. Tam, dzięki swojej niezwykłej pamięci, w ciągu roku tak nauczył się języka angielskiego, że napisał w nim The Remembrances of a Polish Exile, które kilkakrotnie było wznawiane. Zaraz po przybyciu transportu wygnańców do Nowego Jorku Jakubowski udał się do Albany, gdzie przez dwa lata uczył języka francuskiego. Później, nie zważając na przestrogi przyjaciół, wyjechał w długą i niebezpieczną podróż do Meksyku, aby odwiedzić swojego wuja. Rozczarowany spotkaniem powrócił do USA z nadwerężonym zdrowiem. Jak pisze Rosienkiewicz, poeta zapadł na „długą i ciężką" chorobę, która zdefigurowała go na zawsze garbem. Co ciekawe, nie zrobiła ona ponoć najmniejszego wrażenia na synu Malczewskiego, który, żartując, nazywał siebie Ezopem. Gdy jego stan się poprawił, podjął pracę w miasteczku Northampton, gdzie szybko zyskał pozycję szanowanego i lubianego nauczyciela. Rosienkiewicz podkreślał cechy charakteru Jakubowskiego, które nie uszły również uwadze dra Sprague'a oraz Sobolewskiego:

Obyczaje jego byty tak czyste, obejście się $w$ towarzystwie tak ujmujące, iż sobie pozyskat powszechna mitość nie tylko swych rodaków, którzy go zwykle młodym filozofem nazywali, lecz i Amerykanów, którzy mu swej bezinteresownej przyjaźni do ostatniej chwili życia dowodzili ${ }^{14}$.

Autor Wiadomości biograficznej nie podał okoliczności śmierci Jakubowskiego, zaznaczając, że zakończył on życie, nie mając 20 lat, a w jego pogrzebie uczestniczył tylko jeden Polak - Napoleon Kościołowski [sic!], który miał być najbliższym przyjacielem poety.

\section{Krajowe i zagraniczne echa odkrycia wierszy Jakubowskiego}

Ujawnienie wierszy zapomnianego poety stało się wielkim wydarzeniem w środowisku literackim. Jeszcze przed ich publikacją w „Przekroju” ukazał się artykuł Juliana Maślanki o znamiennym tytule Sensacja $z$ historii literatury ${ }^{15}$. O burzliwym życiu oraz utworach syna Malczewskiego pisano zarówno w gazetach co-

${ }^{11}$ M. Rosienkiewicz, Wiadomość biograficzna o Antonim Auguście Jakubowskim, [w:] A. A. Jakubowski, Poezje, s. 69.

1: Podobny tekst J. Maślanki ukazał się też w „Ruchu Literackim”: Poeta tragiczny. (Losy i twórczość A. A. Jakubowskiego), „Ruch Literacki” R. XIII, 1972, z. 5, s. 271-285. 
dziennych, jak i w pismach literackich. Swoją uwagę poświęcili mu m.in. Jarosław Iwaszkiewicz, Jerzy Andrzejewski oraz znakomite znawczynie romantyzmu, takie jak Alina Witkowska czy Maria Danilewicz-Zielińska. Choć recenzenci nie byli jednomyślni co do wartości poetyckiej twórczości młodego wygnańca, wszyscy podkreślali doniosłość odkrycia poezji syna Malczewskiego oraz zwracali uwagę na dramatyczne koleje jego życia, zakończonego samobójstwem. Recenzje z tego okresu zawierają streszczenie najważniejszych informacji zawartych we wstępie Juliana Maślanki do wydania poezji, uzupełnionych o ocenę twórczości Jakubowskiego. Krytycznie do utworów młodego emigranta odniósł się Jerzy Andrzejewski w 48 numerze „Literatury” z 1973 roku, podkreślając, że wiersze Augusta Antoniego „mimo wielu interesujących elementów, nie były i nadal nie są poezją wyższego lotu"16.

Natomiast Jarosław Iwaszkiewicz na łamach „Życia Warszawy” w 1974 roku stanowczo wystąpił w obronie talentu poety, pisząc:

Nie należy, powiadam, lekceważyć tych wierszy. Sa one pełne pesymistycznego dramatyzmu i maja w sobie coś z tego pożegnania ze ztym światem, co dźwięczy w innych wierszach poety, który tez kończyt samobójstwem $w$ tej gościnnej a niebywale obcej ziemi ${ }^{17}$.

Również Tadeusz Polanowski w „Tygodniku Powszechnym” przekonywał, że jest to tomik "wierszy ciekawych, wzbogacających (...) obraz romantycznej liryki"18. Podobnego zdania była Jolanta Tutinas, która w „Nowych Książkach” podkreślała, że jest to poezja dojrzała i oryginalna, zasługująca na umieszczenie jej w tradycji polskiego romantyzmu.

Najbardziej wnikliwe studium twórczości Jakubowskiego zawarła w „Roczniku Literackim" Alina Witkowska. Dostrzegła ona w autorze duchowego dziedzica ojca, spadkobiercę „talentu i fatalnej zarazem doli wielkiego i nieszczęsnego Malczewskiego"19. O uznaniu dla dzieł Jakubowskiego świadczy też fakt, że Alina Kowalczykowa postanowiła umieścić w swojej antologii Pejzaż romantyczny wiersz młodzieńca pt. Burza. Również Agnieszka Ziołowicz i Bogusław Dopart planują wzbogacić antologię wierszy romantycznych I ziarno duszy nagie pozostato o utwory syna Malczewskiego.

Także w zagranicznej prasie ukazały się wzmianki o polskim emigrancie. W 1947 roku w „Polish American Studies” A. P. Coleman i M. M. Coleman opublikowali artykuł pt. Dr William Buell Sprague and August Jakubowski dotyczący ich współpracy oraz wsparcia, jakiego młodemu wygnańcowi udzielił amerykański duchowny. Natomiast w 1971 roku Mieczysław Giergielewicz napisał August Antoni Jakubowski and his "Remembrances of a Polish Exile” na lamach "The Po-

16 J. Andrzeje wski, Z dnia na dzień, „Literatura” 1973, nr 48.

17 J. I was zki e wi c z, Zapomniani, „Życie Warszawy” 1974, nr 11, s. 5.

is T. Pola nowski, A. A. Jakubowski: "Poezje”, „Tygodnik Powszechny" 1974, nr 10, s. 7.

19 A. Wit kow ska, Romantyzm, „Rocznik Literacki” 1973, s. 249. 
lish Review", w którym przybliżył zagranicznej publiczności najbardziej popularne dzieło emigranta, przedrukowując wybrane fragmenty. Z kolei w czasopiśmie „Books Abroad" z 1975 roku Czerwiński opublikował tekst będący laudacją poezji tragicznie zmarłego Jakubowskiego. Możemy w nim przeczytać, że ta „poezja (...) zawiera jedne $z$ najpiękniejszych lirycznych wersów $w$ polskiej literaturze i dlatego zasługuje na wysokie miejsce $w$ polskiej literaturze romantycznej" ${ }^{20}$. Zdaniem Czerwińskiego wczesne dzieła Mickiewicza nie mogą równać się z dojrzałymi poezjami młodego Augusta Antoniego. Swój krótki wywód zamknął on uwagą, że Polska ma dług wdzięczności wobec profesora Maślanki, który odnalazł zapomniane utwory syna Malczewskiego. W nowszych opracowaniach o Jakubowskim wzmiankowal także Wardziński w „The Polish Review” z 1995 roku w tekście English Publications of Polish Exiles in the United States:1808-1897.

Niestety, tak żywe zainteresowanie Augustem Antonim Jakubowskim okazało się chwilowe, a cudem odnaleziony poeta znowu odszedł w zapomnienie. Iwaszkiewicz już w rok po ukazaniu się drukiem Poezji syna Malczewskiego narzekał, że obok Wacława dziejów dzieło to spotkało się z powszechną obojętnością i lekceważeniem. W połowie lat 70 . ubiegłego wieku w Polsce pojawił się znaczący artykuł dotyczący amerykańskiej spuścizny Jakubowskiego. Eugeniusz Żuk dokonał w nim najbardziej drobiazgowej analizy Wspomnień polskiego wygnańca od czasów Juliana Krzyżanowskiego. Tekst ten ukazał się w 1978 roku w „Ruchu Literackim". O The Remembrances... pisała też Elwira Jeglińska w pierwszym tomie Literatury na świecie. Obecnie jedynie Jarosław Ławski przypomina skrupulatnie o wartościach poetyckich liryki Jakubowskiego. Poświęcił mu rozdziały: $W$ romantycznym "mroku gwiazd" w swojej książce Bo na tym Świecie śmierć, Siedem. O Auguście Antonim Jakubowskim w tomie Nihilizm i historia oraz To zawsze wielki człowiek, kto największy z ludzi? (Napoleon, Malczewski, Jakubowski) w książce Literatura - Pamięć - Kultura. Natomiast w 2012 roku w pracy zbiorowej Szkota ukraińska $w$ romantyzmie polskim poświęcił synowi Malczewskiego tekst Ukraina $w$ liryce Augusta Antoniego Jakubowskiego. W 2013 roku razem z Piotrem Oczką opublikował polski przekład The Remembrances of a Polish Exile.

Krótkie wzmianki o Jakubowskim pojawiły się również w kontekście biografii jego słynnego ojca. Tak stało się w 1967 roku w Antonim Malczewskim Marii Dernałowicz, jak i we wstępie do Marii napisanym przez Jarosława Ławskiego. W 10 tomie Polskiego Stownika Biograficznego figuruje biogram Jakubowskiego z błędnymi informacjami. O polskim wygnańcu jako uczniu Liceum Krzemienieckiego bardzo lakonicznie pisze Wojciech Piotrowski w Stowniku krzemieńczan 1805-1832, a także w Życiu umysłowym Krzemieńca w latach 1805-1832. Dowiadujemy się z nich, że August Antoni należał do grona wychowanków znamienitej szkoły, a w 1833 roku został zesłany razem z większą grupą Polaków do Stanów Zjednoczonych. Więcej o samej podróży emigrantów napisał Adam Cedro, wspo-

20 E. J. Czerwiński, August Antoni Jakubowski, „Poezje”, „Books Abroad. An International Literary Quarterly" Vol. 49, No. 2, s. 356. 
minając przy tym o znajomości Jakubowskiego z Numą Łepkowskim, wybitnym muzykiem, który wraz z nim przypłynął do Nowego Jorku ${ }^{21}$.

Jednak ani Aleksander Kozieradzki, ani Gustaw Olizar, Domicjan Mieczkowski czy Franciszek Kowalski w swoich wspomnieniach z czasów krzemienieckich nie piszą nic o koledze Jakubowskim, chociaż pobierali nauki w podobnym czasie. Wtedy właśnie syn Malczewskiego musiał poznać Marcina Rosienkiewicza, który był profesorem w tamtejszej szkole, a później podzielił z nim los emigranta do Stanów Zjednoczonych. Julian Maślanka na początku swego szkicu o Jakubowskim ubolewał, że informacje o profesji Rosienkiewicza nie są potwierdzone w źródłach krajowych, a jedynie w polonijnych ${ }^{22}$. Wątpliwości te rozwiewa ostatecznie sprowadzona przeze mnie z Biblioteki Polskiej w Paryżu kopia rękopisu Rosienkiewicza O powstaniu powiatów Winnickiego, Jampolskiego i Mohylowskiego, który nigdy nie został wydany. We wstępie autor dokonał autoprezentacji, zaznaczając, że w Krzemieńcu był nauczycielem historii i literatury.

Poza tym Jakubowskiego skrótowo wymieniają dwie książki Haimana: Polacy $w$ Ameryce oraz Ślady polskie $w$ Ameryce, pisane w latach 30. XX wieku. Natomiast w dziele Jerzego Lerskiego A Polish Chapter in Jacksonian America syn Malczewskiego figuruje na 66 pozycji listy wygnańców płynących na fregatach „Hebe” i „Guerierra” do Nowego Jorku. Przy jego nazwisku widnieje zapis: „Wyjechał do Meksyku do swego wuja, oficera wojsk meksykańskich"23. Lerski wspomina też dwa razy o autorstwie The Remembrances..., określając dzieło osobliwym epitetem "urocze".

Julian Maślanka odkrył również kolejną wzmiankę o Jakubowskim w bardzo popularnej i wielokrotnie wznawianej antologii Poets and Poetry of Poland autorstwa Pawła Sobolewskiego z 1881 roku. Jego dzieło zawierało noty biograficzne oraz wybór utworów w języku angielskim 50 polskich pisarzy od XVI do XIX wieku. Co ciekawe, w zestawieniu tym zabrakło Norwida, natomiast jako ostatni twórca został zaprezentowany właśnie August Antoni Jakubowski oraz jego wiersz Ode to Napoleon. Nie było to dokładne tłumaczenie polskiego wiersza znanego z Poezji pt. Napoleon, ale jego rozbudowana wersja - dłuższa o 28 wersów.

\section{Nowe ustalenia dotyczące Augusta Antoniego Jakubowskiego}

Minęło ponad 40 lat od opublikowania wierszy Jakubowskiego. Znakomici badacze literatury: Julian Krzyżanowski, Stanisław Pigoń i Julian Maślanka wykonali ogromną pracę, aby odnaleźć jak najwięcej przekazów i źródeł wzmiankujących o poecie. Wydawać by się mogło, że mimo luk w biografii pisarza badacze odkryli

${ }^{21}$ A. Ced ro, Numa Lepkowski i historia nieznanej dedykacji Norwida, "Studia Norwidiana" 2011, nr 29, s. 135.

22 J. M a śla n k a, Z dziejów literatury i kultury, Kraków 2001, s. 103.

${ }^{23}$ J. Le rski, A Polish Chapter in Jacksonian America, Madison 1958, s. 174, Poland's Millennium Series of the Kościuszko Foundation. 
już wszystko, co możliwe. Jednak żaden z nich nie poszukiwał śladów Jakubowskiego po drugiej stronie oceanu, gdzie poeta spędził ostatnie lata życia.

Nie miałabym również takiej możliwości, gdybym nie odnalazła mecenasa Przemysława Jana Blocha, jednego $z$ największych autorytetów $w$ dziedzinie prawa imigracyjnego w Stanach Zjednoczonych. Odznaczony orderem "Zasłużony dla Kultury Polskiej" jest on założycielem Fundacji Rodzinnej Blochów. Ciągle powiększające się zbiory jego fundacji przekazywane są polskim muzeom i instytucjom kulturalnym, tak jak chociażby nieznane listy Krasińskiego ofiarowane Muzeum Romantyzmu w Opinogórze czy odpis „traktatu gdańskiego” z 1677 roku powierzony Muzeum Pałacu w Wilanowie.

Dzięki pomocy Przemysława Blocha dotarłam do wykazu aktów zgonów mieszkańców Northampton, który podaje inną, o dzień wcześniejszą datę śmierci poety niż we wszystkich znanych nam polskich źródłach, opierających się na nekrologu poety opublikowanym w „Młodej Polsce”. Zapis w przytoczonym spisie brzmi następująco:

Jakabowski, Antonius Augustus - from Poland - teacher of French in the Gothic Seminary - 4/24/1837 - aged $21^{24}$.

Udało mi się również odnaleźć kopię nieznanego dotąd nekrologu syna Malczewskiego z „Daily Hampshire Gazette” z 1837 roku, który dostarcza nowych wiadomości o nim i weryfikuje dotychczasowe sądy. Nekrolog należy do nielicznych źródeł, jakie chronologicznie porządkują losy polskiego wygnańca. Wedle zawartych w nim informacji po przyjeździe do Nowego Jorku w 1834 roku Jakubowski wyjechał do Albany, by przy pomocy Sprague'a wydać The Remembrances... Następnie odwiedził wuja w Meksyku, gdzie nie tylko został źle przyjęty, ale też zapadł na ciężką chorobę, która spowodowała u niego poważny uraz kręgosłupa towarzyszący mu do końca życia. Po powrocie miał jeszcze przez rok uczyć języka francuskiego w Miss Dwight's Seminary.

Dzięki „Daily Hampshire Gazette” wiemy już, że nazwisko Napoleona Kościołowskiego, o którym pisał Julian Maślanka, powołując się na Wiadomość biograficzna autorstwa Rosienkiewicza, zostało zniekształcone przez wygnańca. W amerykańskim nekrologu jako najbliższy przyjaciel Jakubowskiego i jedyny Polak biorący udział w pogrzebie pisarza pojawia się kapitan Napoleon Kościałkowski vel Kościałowski. Początkowo był on nauczycielem razem z Jakubowskim w Northampton, później brał udział w wojnie amerykańsko-meksykańskiej w randze oficera w armii generała Scotta. Do historii przeszedł jako pierwszy znany polski osadnik w stanie Kolorado. Mecenas Bloch odnalazł również list rekomendacyjny dla Kościałkowskiego napisany przez samego Abrahama Lincolna.

${ }^{24} \mathrm{Http}$ //files.usgwarchives.net/ma/hampshire/towns/northampton/vitals/death001.txt, 15 IV 2013. 


\section{Daily Hampshire Gazette \\ Northampton, Massachusetts \\ Wednesday, April 26th, 1837}

POLISH EXILE DEAD.--Died in this town, April 25th, Mr. A. A. Tarnava Malczewsk1 vel Jakubowsk1, aged about 21 . Mr. Jakubowski was a Polish nobleman, and a member of a college in Poland, previous to the late revolution. He was too young to engage in the fatal struggle, but was a member of a patriotic club. After the downfall of that unhappy country, he, with a considerable number of others, were obliged to flee, to escape banishment to siberia. They lled to Austria, where they were imprisoned. The number of prisoners were above three hundred. After being imprisoned about a year, they were compelled to embark for America, where they arrived in 1834. Mr. Jakubowski soon went to Albany, where he published a small origlnal book, entitled, "Remembrances of a Polish Exile". which was introduced to the American public by the Rev. Dr. Sprague. Subseguently, he went to Mexico, to join an uncle, but the climate being unfavorable to his health, returned to New York, where he experienced a severe fit of sickness. After his recovery he came to Northampton, and for about a year has been teacher of French in Miss Dwight's seminary. He was joined during the last summer, by Mr. Napoleon Koscialowski, a companion of his exile, who is now in Northampton to mourn his loss. Mr. Koscialowskl was, we belleve, actlvely engaged in the Pol ish revolution, and was distinguished in bis own country, as a poet. Mr. Jakubowskl was, for sometime previous to his death, severely afflicted with an affection of the spine, which much disfigured his person. He was amiable and affectionate in his disposition, and much beloved by all who knew him. He was remarkable for the uprightness of his conversation. During his residence here, he has not been known to indulge in any trivial remark.

His funeral will take place at the Misses osborn's, this (Tuesday) afternoon at 4 o'clock.

Nekrolog Augusta Antoniego Jakubowskiego zamieszczony w „Daily Hampshire Gazette” 26 kwietnia 1837 roku $^{25}$

${ }^{25}$ Thumaczenie (jeśli nie zaznaczono inaczej, wszystkie tłumaczenia pochodzą od Autorki): Polski wygnaniec nie żyje. Zmarły w tym mieście A. A. Tarnava Malczewski vel Jakubowski miał lat około 21. Jakubowski był polskim szlachcicem, uczęszczającym do szkoly średniej w Polsce, przed ostatnim powstaniem. Byl zbyt młody, aby wziąć udział w strasznej walce, należał jednak do patriotycznego stowarzyszenia. Po upadku nieszczęsnego kraju, wraz ze znaczną liczbą innych, musiał uciekać, by uniknąć wygnania na Syberię. Uciekli do Austrii, gdzie byli więzieni. Liczba więźniów wynosiła ponad trzysta osób. Po trwającym półtora roku uwięzieniu, zostali oni zmuszeni do wejścia na statek plynący do Ameryki, gdzie przybyli w 1834 roku. Jakubowski wkrótce przybył do Albany, gdzie opublikował małe, oryginalne dzieło, zatytułowane The Remembrances of a Polish Exile, które zostało przedstawione amerykańskiej publiczności przez pastora dr. Sprague’a. Potem [Jakubowski] pojechał do Meksyku, aby dołączyé do wuja, ale tamtejszy klimat był niekorzystny dla jego zdrowia, powrócil więc do Nowego Jorku, gdzie przeżył poważny atak choroby. Kiedy wyzdrowial, udał się do Northampton, gdzie przez okolo roku był nauczycielem języka francuskiego w Miss Dwight's Seminary.

Dolączył do niego podczas ostatniego lata Napoleon Kościalowski, towarzysz jego wygnania, który jest teraz w Northampton, aby oplakać jego stratę. Kościałowski, jak wierzymy, aktywnie dzialal w polskim powstaniu i był znany w swoim kraju jako poeta. Jakubowski przez pewien czas poprzedzający swoją śmierć został dotknięty poważnym urazem kręgosłupa, który bardzo zniekształ- 
Światło na życie i twórczość Jakubowskiego rzuca także rękopis listu Rosienkiewicza do Eustachego lanuszkiewicza z 8 czerwca 1838 roku $^{26}$, który kryje w sobie pierwszą redakcję Wiadomości biograficznej o Jakubowskim zamieszczoną później w Pismach pośmiertnych. Nadawca dowiedział się o planach wydania publikacji poświęconej polskim emigrantom w Ameryce, dlatego jako współwygnaniec przebywający w Filadelfii chciał udzielić Januszkiewiczowi informacji z pierwszej ręki. W tym celu napisał Wiadomość o tułaczach polskich w Amery$c e$, opatrzoną dedykacją: Cieniom ziomków zmartych w Ameryce. Zamieszczona w niej notatka o synu Malczewskiego była piątym biogramem z dwunastu krótkich życiorysów. Zawiera ona kilka ciekawych informacji, z których zrezygnował Rosienkiewicz w ostatecznej edycji. Na przykład dowiadujemy się z niej, że Jakubowski był „znacznie” zdefigurowany garbem oraz że miał powrócić do Nowego Jorku z Meksyku w 1836 roku. Pojawia się także stwierdzenie, że tak postąpił on w języku angielskim w czasie rocznego pobytu w Ameryce, że "już był w stanie pisać nim prozą i wierszem", podczas gdy w planowanym wydaniu z 1839 roku Rosienkiewicz stwierdzał, że po prostu myśli swoje przelewał na papier w obcym języku. Zupełnie inaczej były nauczyciel Liceum Krzemienieckiego pisał też o poezjach Jakubowskiego, zmieniając przy tym hierarchię wzorów, którymi ich autor się inspirował: Malczewski wyprzedza w niej Mickiewicza. Tekst zawiera także odpowiedź na pytanie o wpływy literatury amerykańskiej na jego twórczość: „przenosił nad wszystkich ojczystych pisarzy i wszystko, co nosi charakter narodowy, porywało duszę jego”. Pojawia się również zdanie: „Odznaczał się szczególnie zdrowym rozumowaniem bez pedantyzmu".

Ponadto list ten zawiera jeszcze wiersz Dwie gwiazdki Jakubowskiego, który został umieszczony w nekrologu poety w „Młodej Polsce” parę miesięcy później (10 września) oraz Wiadomość do redakcji, a także informację o zgonie Ignacego Parysa - wszystko opublikowane w tym samym numerze! Utwór Dwie gwiazdki ma zaznaczone innym atramentem kilka wersów. Co ciekawe, dokładnie te wersy zapisano $\mathrm{w}$ nekrologu rozstrzelonym drukiem, a jest to jedyny znany nam zapis tego liryku w takiej formie, niepojawiający się już w Pismach pośmiertnych z 1839 roku. Dla porównania przytaczam pierwowzór Wiadomości biograficznej o Jakubowskim z rękopisu w całości:

Jakubowski August Antoni -

zaledwie Jakubowski ujrzat światło słoneczne, jużci posępna chmura kolebkę jego otoczyła. Okoliczności bowiem tak zrządzity, iz $w$ dziesiątym dopiero roku życia

cil jego osobę. Był sympatyczny, miał miłe usposobienie i był bardzo kochany przez wszystkich, którzy go znali. Był znany ze swej prawości. Podczas jego pobytu tutaj nie dał się poznać jako ktoś ulegający niewłaściwym zachciankom. Jego pogrzeb odbędzie się u Panien Osborn, w ten wtorek o godzinie czwartej po południu.

26 Rękopis o sygnaturze 7043 znajduje się w Bibliotece Jagiellońskiej. Jestem ósmą zainteresowaną nim osobą, odkąd trafił do archiwów BJ. Ostatnio korzystał z niego Eugeniusz Żuk, który nie poddał dokumentu analizie, lecz wspomniał o nim jedynie w przypisie do "The Remembrances of a Polish Exile" Augusta Antoniego Jakubowskiego, opublikowanym w "Ruchu Literackim" w 1979 roku. 
poznat rodziców, których sqdzit się być pozbawionym. Wówczas poznat powaby życia, którymi nie długo się cieszyt, gdyż wkrótce utracit ojca, a od matki, którą nad życie ubóstwiat, oddzielity go na zawsze niestety! wypadki rewolucji listopadowej. Urodzit się na Podolu, a poczatkowe kursy nauk odbyt w szkole Czackiego. Wspomnienie tego wielkiego męża wzniosty ducha jego i rozpality w miodym sercu święty ogień wolności i milości ojczyzny. Od chwili rozstania się z matką i ojczyzną nikt go nie widziat wesotym - posępność wszakże jego nie była dzikg i rozpaczająca, lecz dodawata mu serca do znoszenia cierpień nieoddzielnych do życia tutaczego, a nadzieja pomyślniejszej przyszłości ożywiała go do ostatniej chwili życia. Zawsze pocieszat kolegów $i$ nie dawat im upadać na umyśle. Wolność, ojczyzna i matka zajmowaty cate jego serce i myśli.

[...]

Przyrodzenie obdarzyto Jakubowskiego nadzwyczajna pamięcią. W przeciagu rocznego pobytu $w$ Ameryce tyle postapit $w$ języku angielskim, iz juz byt $w$ stanie pisać nim proza $i$ wierszem. Ksiażeczka Remembrances of a Polish Exile, której wyszto trzy wydania, acz nie jest doskonata, jak sam wyraza w przemowie, maluje jednak jego duszę. Niepośledni miat talent Jakubowski do poezji, w której nie uganiat się za próżnymi blyskotkami, lecz go suma wielkiej myśli zajmowata. Malczewski, Mickiewicz, Szekspir i Byron byli jego wzorami, przenosit nad wszystkich ojczystych pisarzy, $i$ wszystko, co tylko nosi charakter narodowy, porywato duszę jego. Czułość przy wzniostości myśli są cecha jego nielicznych utworów poetycznych. Z czasem zajątby niechybnie na polskim Parnasie niepoślednie miejsce. Obyczaje jego byty tak czyste, obejście się $w$ towarzystwie tak ujmujace, iz sobie pozyskat serca nie tylko swych ziomków, którzy go zwykle mtodym filozofem zwali, lecz Amerykanów wśród których przebywat serdecznie go kochali [sic:] i przyjaźni mu do końca życia dowodzili. Odznaczat się szczególnie zdrowym rozumowaniem bez pedantyzmu.

Przez lat dwa prawie byt nauczycielem języka francuskiego w Albanii [sic!] (N.Y.). Zbyt młody, ażeby żmudne powotanie nauczycielskie przywiazać go mogto do miejsca, umyślit zwiedzić Meksyk, a przy tym odwiedzić krewnego tam zamieszkatego. Mimo odradzań przyjaciót uskutecznit swe postanowienie; lecz dla klimatu, którego znieść nie mógt $i$ nie doznawszy od krewnego przyjęcia, jakiego się spodziewat, wrócit w 1836 do N. Yorku ze znacznie nadwyrężonym zdrowiem. Przebywszy w tym mieście ciężka chorobę, znacznie zdefigurowany zostat garbem na plecach, co bynajmniej wrażenia na nim nie czynito. Często żartowat z swej figury, nazywając się Ezopem. Stamtąd udat się do miasteczka Northampton w stanie Massachusetts, gdzie znowu byt nauczycielem francuskiego języka, w szkole Panny Dwight i również jak od mieszkańców Albanii, byt kochany. Zakończyt tam życie J. 25 kwietnia 1837.

Jak już wspomniałam, Fundacja Blochów zgromadziła najbogatszy jak dotąd zbiór XIX-wiecznych wydań The Remembrances of a Polish Exile. Ten niewielki, 69-stronicowy tomik zawierający szkice poświęcone polskiej kulturze i literaturze cieszył się dużą popularnością, o czym świadczą jego liczne edycje w Ameryce:

- Albany: Packard and Van Benthuysen, 1835, s. 69.

- Auburn, NY: Allen \& Lounsbury, 1835, s. 72.

- Philadelphia: Adam Waldie, 1835, s. 69. 
- Philadelphia: C. Sherman \& Co., 1835, s. 72.

- Philadelphia: Haswell and Fleu, 1836, s. 69.

- Auburn, NY: Finn \& Rockwell's Steam Power Press, 1850, s. 6427.

Dotąd wśród polskich badaczy panowała konfuzja co do amerykańskich wydań tego dzieła, ponieważ nie mieli oni do nich pełnego dostępu. Warto pamiętać, że Julian Maślanka wiedział tylko o dwóch pierwszych edycjach The Remembrances... i powątpiewał $\mathrm{w}$ istnienie trzeciego wydania, o którym wspominał Rosienkiewicz $^{28}$. Po zapoznaniu się $\mathrm{z}$ unikatową kolekcją mecenasa Blocha okazało się, że w ostatnim wydaniu The Remembrances... z 1850 roku doszło do plagiatu, którego dokonał wydawca Edward de Novasky. Usunął on z książki zarówno wstęp dra Sprague'a, jak i podpis A. J. pod dedykacją To the Ladies of America i na jego miejsce wstawił własne inicjały. Dzięki tej sztuczce Novasky zapewne był postrzegany jako autor całego dzieła. Poza wspomnianymi zmianami edycja z 1850 roku pokrywa się w zupełności z tekstem wydania „auburnskiego" z 1835 roku.

W czasie dalszych badań okazało się, że więcej pisarzy w Ameryce wykorzystało do własnych celów dzieło młodego polskiego poety. W 1838 roku Thomas Dunn English, znany ze zwady z Edgarem Allanem Poe, napisał artykuł o polskiej poezji na łamach „The Gentleman's Magazine”. Zamieścił w nim dłuższą wzmiankę o Jakubowskim, a także wybór fragmentów polskiej poezji - dokładnie tych samych, które syn Malczewskiego przetłumaczył w The Remembrances..., nie podając przy tym ich źródła. Wśród nich znalazły się The Girl Korsaka, dwa fragmenty Marii Malczewskiego, Gdyby orłem być Gosławskiego (English pomyłkowo przypisał ten wiersz Goszczyńskiemu) oraz fragment Dziadów i Farysa Mickiewicza. Nie można mieć wątpliwości, że taka zbieżność tłumaczonych fragmentów nie jest przypadkowa, tym bardziej że autor w notce o Jakubowskim wspomniał o jego Wspomnieniach polskiego wygnańca. Poprawki wprowadzone przez Englisha są niewielkie, powstały w celu wygładzenia niedoskonałości tłumaczenia młodego twórcy dopiero uczącego się nowego języka. Styl notatki bardzo przypomina wspomnienie o Jakubowskim z Poets and Poetry of Poland napisanego przez Pawła Sobolewskiego. Padają $\mathrm{w}$ niej identyczne sformułowania ${ }^{29}$ oraz pojawia się ten sam wiersz Ode to Napoleon, którego Rosienkiewicz nie zamieścił w planowanym wydaniu Pism pośmiertnych. The following ode to Napoleon, for which I am indebted to an eminent Polish pianist of this city, was written by him, on ship-board, off Gibraltar. It has never before appeared in print, either in Polish or English ${ }^{30}$ - wyjaśnił autor artykułu o polskiej poezji, wspominając tym samym o kolejnej osobie

2: W rozdziale poświęconym The Remembrances... omawiam różnice między kolejnymi wydaniami tego dziela.

${ }^{2 k}$ J. M a śl a n k a, Z dziejów literatury i kultury, s. 107.

${ }^{29}$ Zarówno P. Sobolewski, jak i T. Dunn English wspominają o ulotnych fragmentach poezji [fugetive pieces of poetry] Jakubowskiego oraz podobnie przedstawiają zachowanie jego stryja jako haughty manner [wyniosła, dumna postawa].

3) W tłumaczeniu: Zamieszczona poniżej oda do Napoleona, którą zawdzięczam eminentnemu polskiemu pianiście z tego miasta, została napisana przez niego [Jakubowskiego] na pokładzie statku u wybrzeży Gibraltaru. Nigdy wcześniej nie ukazała się ona drukiem, ani po polsku, ani po angielsku. 
z Polski, mającej dostęp do twórczości Jakubowskiego. W 1838 roku Dunn English przebywał w Filadelfii. Jedynym polskim „eminentnym” muzykiem w tym mieście był wówczas Leon Gawroński, który uczył gry na gitarze w Northampton, gdzie Jakubowski był w tym samym czasie nauczycielem języka francuskiego. Gawroński tworzył także kompozycje na fortepian (np. The Exile's Farewell To Poland wydaną w Baltimore w 1844 roku), dlatego też prawdopodobnie to on był owym tajemniczym pianistą-informatorem. Artykuł w "Gentleman's Magazine" nie dostarcza nieznanych wiadomości na temat syna Malczewskiego, poza intrygującą wzmianką "he died of a broken heart" [umarł z powodu złamanego serca]. Może ona odnosić się do urazy spowodowanej nieprzychylnym przyjęciem stryja, opisanej bezpośrednio wcześniej, ale niewykluczone, że Gawroński pracujący razem z Jakubowskim w Northampton mógł zrobić aluzję do jego domniemanego uczucia do swojej uczennicy. Warto przytoczyć w całości wzmiankę o Jakubowskim:

Among the Poles who emigrated to this country, after the termination of their disastrous struggle for liberty, was one by the name of Iakaboski. He obtained a situation as teacher in a highly respectable family, where he was much esteemed for the goodness of his heart, and the brightness of his mind. He soon heard a relative of his, a brother of the great Malczewski, was a general [s.] of artillery in the Mexican army. He went in pursuit, and found him; but the haughty manners of his proud realative, hurt the high spirit of the boy, for he was little else, and he returned in sadness to the United States. Before he reached the place from whence he set out, he died of a broken heart. Besides his fugitive pieces, he wrote a small work in English, called "The Remembrances of a Polish Exile" ${ }^{\prime \prime}$.

W celu dotarcia do źródeł związanych z pobytem Jakubowskiego w Ameryce Przemysław Bloch nawiązał kontakt z Muzeum Historycznym w Northampton, gdzie syn Malczewskiego spędził ostatnie lata życia. Tam też wykonano kopie trzech katalogów z Gothic Seminary z lat 1836-1838, które wymieniają Monsieur Yakubosky jako nauczyciela języka francuskiego, a także zamieszczają adnotację o jego śmierci. Broszury nie tylko stanowią dowód zaświadczający o zawodowych poczynaniach Jakubowskiego, ale również pokazują, jak był postrzegany przez otoczenie. Informatory te bowiem prawie 200 lat temu należały do jednej z wychowanek Seminarium Gotyckiego - Clarissy Stebbins ${ }^{32}$, która naniosła na

31 T. Dunn English, The Poetry of Poland, "The Gentleman's Magazine”, ed. W. E. Bur to n, v. III, from July to December, Philadelphia 1838, s. 250. W tłumaczeniu brzmi ona tak: W'́ród Polaków, którzy wyemigrowali do tego kraju po zakończeniu nieszczęsnej walki o wolność byl jeden o nazwisku lakaboski. Uzyskał on posadę nauczyciela w bardzo szanowanej rodzinie, gdzie byl niezwykle ceniony za dobroć serca $i$ jasność umyslu. Wkrótce dowiedział się o istnieniu swojego krewnego, brata wielkiego Malczewskiego, który był generałem [sic!] artylerii w armii meksykańskiej. Udał się w pościg i odnalazł go, ale wyniosła postawa jego dumnego krewnego zraniła wzniosłego ducha chłopca i powrócił, pogrążony w smutku, do Stanów Zjednoczonych. Zanim dotarł do miejsca, z którego wyruszył, zmarl z powodu złamanego serca. Poza ulotnymi drobiazgami napisał niewielką pracę $w$ języku angielskim, o nazwie "Wspomnienia polskiego wygnańca".

32 Wszystkie trzy katalogi były adnotowane wylącznie przez Clarissę Stebbins. Z tym, że ten z 1838 r. jej późniejszą ręką, na pewno po 1887 r., gdyż przy nazwisku Lucy Dewey Clarissa napisała 
nie swoje uwagi co do konkretnych osób. Z trudem udało się odczytać wyblakłe i niewyraźne pismo kilkunastolatki. Jej komentarze dotyczące Augusta Antoniego zawsze były pochlebne, w przeciwieństwie do uwag o innych nauczycielach i uczniach szkoły. W katalogu z 1836 roku zanotowała przy Jakubowskim: love (przy większości nauczycieli pojawiło się określenie hate), a potem mało czytelne zdanie kończące się truly good, a poniżej: loved by all especially by J. Bowers ${ }^{33}$.

\section{FI โ S T}

\section{N N UAL, CATAL()GU S.}

(1) TII

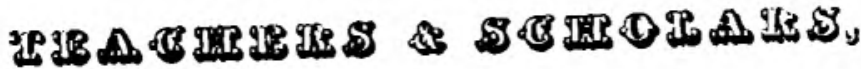

I. 7 ก

\section{GOTIIO BMWIJAMY,}

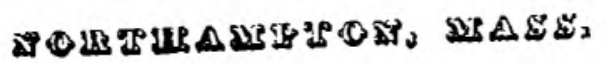

O 0 T $0 \mathbf{3} \mathbf{2}$

ป๑ษ

Pierwsza strona First Annual Catalogue of the the Teachers and Scholars in the Gothic Seminary z 1836 roku

deceased, a ta zmarła właśnie w 1887 r. Katalog z 1837 r. był zapewne przeznaczony przez Clarissę dla Nancy T. Rand, from her old friend \& schoolmate C.S.L., jako pamiątka, ale nastąpiła pewnie jakaś zmiana w zamiarach, stąd przekreślenie. Warto zauważyć, że wszystkie trzy katalogi zostały podarowane do muzeum przez Suzannę Lathrop (1860-1938), córkę Clarissy Stebbins Lathrop (1823-1908), więc do końca pozostały w rękach rodziny Clarissy.

${ }^{3}$ Dla porównania w tym samym katalogu Clarissa napisała przy nazwisku J. Bowers: hate, L. Dewey: good, a rok później o Mary Pierce: high opinion of herself. 


\section{OFTIOAB}

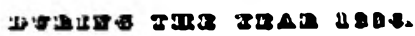

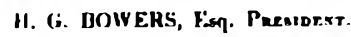

J. D. WillT.YEY, TaEseren.

J. II. BLTI.F.R. Secaetanr.

\section{TR OBTEBa.}

JUSEDH PFATEY, D. D. Mr.r. JOHN TODD.

A. S. ABEIA.

I.FiWIS STRONG, Eaq.

J. H. BUTLE.R.

JAMLS HUBUEN, ESQ.

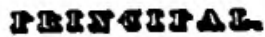

MIRN NAROARETTE DWIGET.

\section{TลAง}

i Mies E.LIzant.TII LoNo.

MIS MARTHA I.YMAN.

- Mige PRANCFS P. DICKINEON.

¿Mies MARY D. K. DWIGITT.

IMIEO JANE N. GTRONG.

PMIES IAARIET N. CLARK.

"NIEN IIETTY \& BCTLER.

- Mien Nancy d. yolvo, ME CAROLINE M. YOUNG Muic Teardas.

i Momaizun A. A. YAKUBOSKY, Freal Teatr.

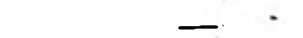

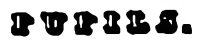

sencor Depcetarnt.

\section{Nom.}

Ceroline S. Anthony, If Eliza H. Bates, i:

Helea S. Bell,

f. Mery H. Benuelu,

F Horriet M. Botu,

pijolia R. Bowera.

fipgences A. Bowers.

- Wirlor Teia

\section{Insidan.}

Providence, R. I.

Northerptom ta n.

Howerhin, N. I. .. :

Mencherter, Fi. . . I

Sontrick.

Northanplon.

, The

Wykaz wladz, nauczycieli, zarządu szkoły i początek spisu uczniów z katalogu Gothic Seminary z 1836 roku

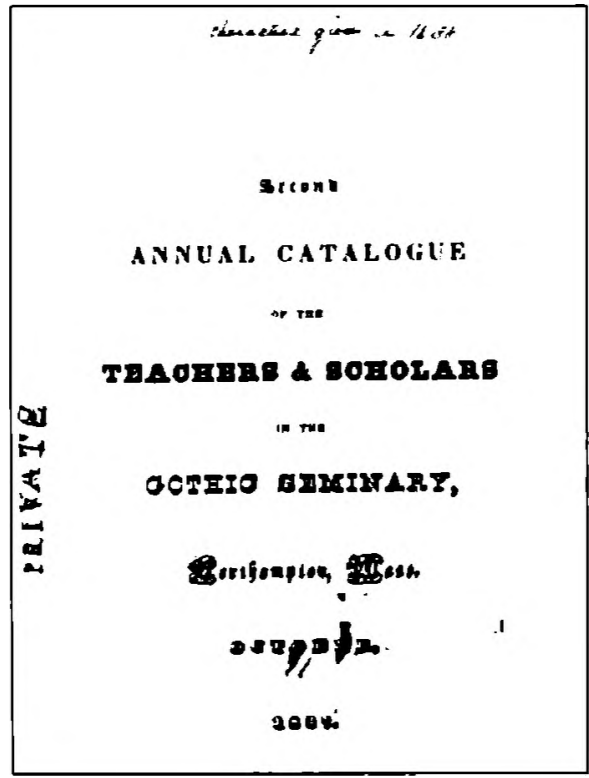

Pierwsza strona Second Annual Catalogue of the the Teachers and Scholars in the Gothic Seminary z 1837 roku 


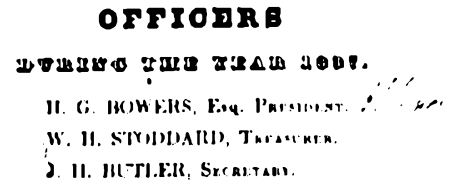

Tลช8 มอย.

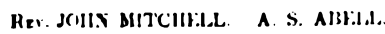

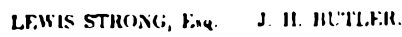
JAMES HUUEN, EsQ. W. II. STUDUAILD.

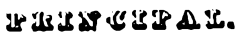
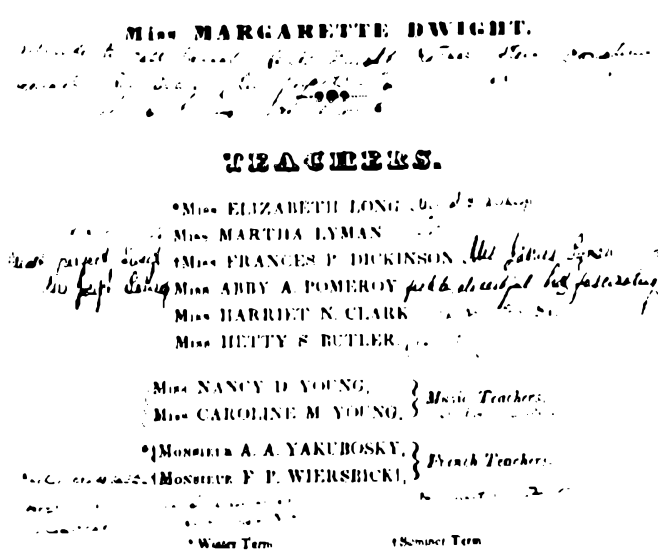

Wykaz władz, nauczycieli, zarządu szkoły i początek spisu uczniów z katalogu Gothic Seminary z 1837 roku. Przy nazwisku Jakubowskiego pojawia się informacja, że uczył języka francuskiego w semestrze zimowym, a zmarł w semestrze letnim. Wtedy też zastąpił go inny Polak, Feliks Paweł Wierzbicki, który przeszedł do historii jako twórca pierwszej książki o Kalifornii. Clarissa Stebbins napisała przy jego nazwisku złośliwą uwagę, że w czasie lekcji odpytuje uczniów lamaną angielszczyzną

Ważnym kontaktem dotyczącym Jakubowskiego, jaki Julian Maślanka nawiązał ze Stanami Zjednoczonymi, była korespondencja z W. S. Flisińskim, który po artykule badacza o poecie w „Przekroju” napisał list do redakcji w tej sprawie. Donosił w nim, że w miejscowości, gdzie polski wygnaniec zakończył życie, znajduje się jego nagrobek ufundowany przez uczennice. Przemysław Bloch sprowadził z muzeum w Northampton również mapę cmentarza, na którym został pochowany Jakubowski i osobiście odnalazł jego grób. Wykonał zdjęcia, a także zatroszczył się o miejsce wiecznego spoczynku polskiego wygnańca. Dzięki jego staraniom okoliczni mieszkańcy Northampton zapalają znicze i kładą kwiaty przy nagrobku Jakubowskiego. Również w czasie tej wizyty okazało się, że poeta najpierw został pochowany w kwaterze rodzinnej swojej uczennicy Lucy Dewey, a później jego nagrobek przeniesiono do sektora miejskiego przy samej krawędzi cmentarza. Było to miejsce przeznaczone dla biedoty i samobójców (do lat 70. XX wieku nie posiadało nawet ogrodzenia).

Dzięki odkryciu nowych źródeł i wskazówek dotyczących Jakubowskiego można postawić pewne hipotezy odnośnie do nieustalonych do tej pory faktów biograficznych. Należy do nich sporna kwestia udziału młodego poety w powstaniu. O tym, że Jakubowski miał uczestniczyć w walkach narodowowyzwoleńczych, wspominał Julian Maślanka, powołując się na przedmowę Goszczyńskiego do Marii oraz na Polski Stownik Biograficzny, gdzie nazwano pisarza „ochotni- 


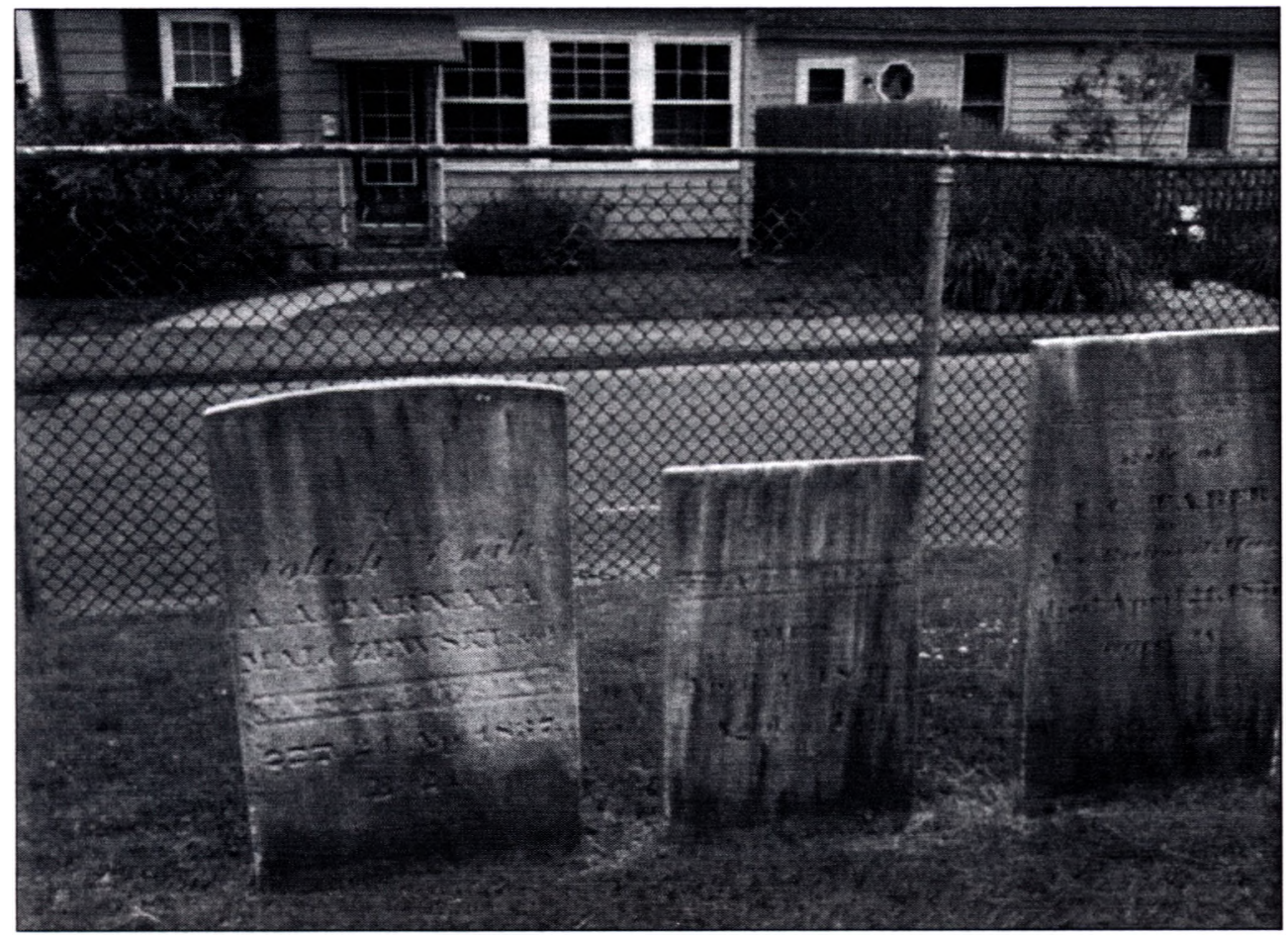

Nagrobek A. A. Jakubowskiego na cmentarzu w Northampton, pierwszy od lewej strony. Zdjęcie zostało wykonane przez Przemyslawa Jana Blocha w 2013 roku

kiem korpusu Dwernickiego"34. Natomiast w przedmowie Rosienkiewicza do tomiku Jakubowskiego znajduje się tylko stwierdzenie, że August Antoni zazdrościł starszym kolegom możliwości walki i zagrzewał ich do czynu. W nekrologu w „Daily Hampshire Gazette” poza wzmianką o tym, że był za młody, aby walczyć z bronią w ręku, czytamy, że "he was a member of a patriotic club" [był czlonkiem patriotycznego stronnictwa] ${ }^{35}$. Również w nekrologu w „Młodej Polsce” nikt nie wspomina o Jakubowskim jako o powstańcu. Podobnie jest $w$ antologii Pawła Sobolewskiego, jak i w przedmowie Sprague'a do The Remembrances...

Wydaje się, że gdyby rzeczywiście Jakubowski miał na swoim koncie udział w partyzantce, nie zataiłby tego w Ameryce, a jego polscy znajomi wiedzieliby o tym. Rosienkiewicz z pewnością chętnie wplótłby ten fakt do biografii poety. Również w spuściźnie poetyckiej Jakubowskiego poza utworami przesiąkniętymi buntem, rozpaczą i chęcią zemsty nie ma takich, które bezpośrednio sugerowałyby udział w powstaniu. Nie można zapominać, że jego twórczość była silnie autobiograficzna i nawiązywała do przełomowych wydarzeń z życia syna Malczewskiego ${ }^{36}$.

" Taką informację można również znależć w Stowniku biograficznym oficerów powstania listopadowego Roberta Bieleckiego.

55 „Daily Hampshire Gazette”, 26 IV 1837.

36 Hipoteza ta wymaga dalszej weryfikacji w świetle informacji zawartych we wspomnianych slownikach biograficznych. 
Kolejnym argumentem przemawiającym za tym, że Jakubowski nie uczestniczył w partyzantce Zaliwskiego, jest fakt, że Rosienkiewicz w swoim rękopisie, przedstawiając siebie jako uczestnika tego właśnie zrywu i opowiadając o towarzyszach broni, nie wspominał o poecie. Dodajmy, że O powstaniu powiatów Winnickiego, Jamposkiego i Mohylowskiego przygotowywał do wydania w tym samym roku co Poezje Jakubowskiego.

Pamiętnik historyczny o wyprawie partyzanckiej do Polski roku 1833 napisany przez Karola Borkowskiego, będący jednym z najbardziej kompetentnych źródeł na temat tych wydarzeń, również nie wymienia Augusta Antoniego. Jedyny Jakubowski, jaki brał udział w partyzantce Zaliwskiego, to Michał Jakubowski z oddziału Białkowskiego (syn leśniczego, o którym wspomina również Julian Maślanka), ale ten został powieszony przez Rosjan w Brodach. Przemysław Bloch w korespondencji ze mną stwierdził:

Sądzę, że musi się Pani pogodzić z myślą, że Pani ulubieniec raczej nie brał udziału $w$ żadnych walkach narodowowyzwoleńczych, choć nie $z$ braku ochoty. O tego rodzaju mtodych ludziach, często emigrantach $z$ Wotynia, przesiadujacych $w$ przygranicznych dworach i pałacach galicyjskich, których na przetomie 1832/1833 $\mathrm{r}$. wytapali Austriacy $i$ wydalili z kraju, np. poprzez Triest, pisze Franciszek Wiesołowski w swoich wspomnieniach zawartych w „Pamiętniku historycznym” Borkowskiego.

Moje kolejne przypuszczenie dotyczy matki Augusta Antoniego, nieznanej nawet $\mathrm{z}$ imienia, którą według Rosienkiewicza poeta "nad życie ubóstwiał" ${ }^{37}$. Autor Wiadomości biograficznej o Jakubowskim podkreślał, że od momentu rozstania z nią na zawsze utracił on szczęście, jednak była to świadoma ofiara dla ojczyzny. Potwierdzenie tej niezwykle silnej więzi możemy odnaleźć w wierszach Jakubowskiego. Sam Rosienkiewicz konstatował: „Wolność, ojczyzna i matka całe jego serce i myśli zajmowały i nimi tchną wszystkie jego pisma"38. Na końcu swojego szkicu przyjaciel poety zaznaczał, że publikuje te wiersze z myślą o jego matce, „którą on tak czule kochał" ${ }^{39}$. Nauczyciel przyznawał jednak, że nie wie, czy ona jeszcze żyje. Natomiast w Polskim Stowniku Biograficznym figuruje ogólnikowa wzmianka, że kobieta zmarła po 1832 roku $^{40}$. Gdyby zmarła przed 1834 rokiem, poeta zapewne podzieliłby się tą informacją z towarzyszem podróży - Rosienkiewiczem, który napisał swój wstęp 15 maja 1839 roku. Również sam August Antoni w wierszu pt. Dzwon wieczorny, pisanym w Trieście 24 października 1833 roku, zadręczał się niepewnością co do losu matki i myślami o jej śmierci.

Studiując drzewo genealogiczne Jakubowskich, odnalazłam Julię Jakubowską, córkę Tadeusza i Wiktorii Ewy Burczyńskiej, herbu Lubicz, urodzoną ok. 1790 roku, która nigdy nie wyszła za mąż. Nieznana pozostaje także data jej

\footnotetext{
${ }^{37}$ M. Rosienkie wi c z, Wiadomość biograficzna..., s. 67.

3k Ibidem, s. 68.

39 Ibidem, s. 70.

*1 Polski Stownik Biograficzny, t. 10, red. nacz. K. Le p s z y, Wrocław 1962, s. 382.
} 
śmierci. Ciekawe jest to, że imię Julia nosi także matka tytułowego bohatera Majora Aleksandra, dzieła Jakubowskiego inspirowanego biografią autora. W serwisie genealogicznym M. J. Minakowskiego Genealogia potomków Sejmu Wielkiego pojawia się również August Antoni, a jego matka, figurująca jako N.N., ma podany właśnie 1790 rok jako orientacyjną datę urodzin. Hipoteza ta pozostaje jednak słabo udokumentowana, jest prawdopodobna jedynie w kontekście ram czasowych.

Zadziwiająca zmowa milczenia wszystkich źródeł, skrupulatnie omijających nazwisko matki Augusta Antoniego, wydaje się niezwykle znacząca. Jarosław Iwaszkiewicz w Rozmowach o książkach podkreślał wyjątkowość tej sytuacji na tle całej historii literatury: „Jakubowski (...) od samego zarania ma życie osobliwe i dziwaczne. Przede wszystkim wbrew łacińskiej tezie prawniczej, że mater semper certa - nie wiadomo, kto był jego matką" ${ }^{\prime 1}$. Rodzina tajemniczej damy skutecznie zatuszowała całą sprawę i zapewne musiała być wysoko postawiona, skoro osoby niewątpliwie wprowadzone $w$ tę kwestię bez wyjątku respektowały jej wolę.

William Buell Sprague we wstępie do The Remembrances... napisał o swoim podopiecznym, że "he belonged to a family of a great respectability in his native country" [należał do bardzo szanowanego rodu w swoim ojczystym kraju] ${ }^{42}$. Nie da się ukryć, że ród Jakubowskich nie był aż tak znaczący. Dotarcie do grobu poety, na którym wyryto napis: $A$. A. Tarnava Malczewski, vel Jakubowski podaje w wątpliwość prawdziwość nazwiska Jakubowski. Skrót „vel” oznaczający „albo”, "Czyli", jeśli występuje pomiędzy dwoma nazwiskami, zwykle wskazuje na to, że przynajmniej jedno $\mathrm{z}$ nich jest fałszywe lub celowo zmienione po to, by jego właściciel mógł ukryć tożsamość.

Ustalenie daty narodzin Augusta Antoniego pozwala wysnuć sensacyjną, ale prawdopodobną hipotezę dotyczącą tożsamości tajemniczej damy. W 1815 roku Antoni Malczewski postarał się o urlop wojskowy i wyjechał na Wołyń. Niektóre źródła podają, że właśnie tam miał poznać Franciszkę Marię Lubomirską z domu Załuską, do której w Warszawie zapałał gorącym uczuciem około połowy 1815 ro$\mathrm{ku}^{43}$. 22-letnia księżna przyjechała właśnie wtedy do stolicy, aby przeprowadzić rozwód z Fryderykiem Lubomirskim. Potwierdza to sam brat Franciszki, Józef Załuski, który opisał całą sprawę w 1855 roku na prośbę Turowskiego do jego sanockiego wydania Marii w pierwszej serii Biblioteki Polskiej. We wspomnianym liście przytoczonym przez wydawcę można przeczytać:

W roku 1815, kiedy w. ks. Konstanty organizowat wojska kongresowego Królestwa Polskiego, ani Btędowski, ani Malczewski nie byli w tymże wojsku. Gdy siostra moja zamężna Fryderykowa Lubomirska przyjechała do Warszawy, obaj rzeczeni koledzy, jako Wotynianie, jej z dawniejszych lat znajomi, uczęszczali do niej tak, ze ich codziennie widywatem, bo statem $w$ jednym domu z moja siostrą. Wkrót-

11 J. I was zki e wi c z, Zapomniani, „Życie Warszawy” 1974, nr 11, s. 5.

12 A. A. Ja kub ow ski, The Remembrances of a Polish Exile, Philadelphia 1836, s. 7.

is H. Ga c ow a, "Maria" i Antoni Malczewski. Kompendium źródtowe, wstęp J. Maciejewski, Wroclaw 1974, s. 218, Materiaty Literackie, 1. 
ce zwiazaly się stosunki bliższe Malczewskiego z moją siostra. Ona wyjechała do Szwajcarii, Malczewski pojechat $z$ niq $i$ wtenczas to zwiedzit jezioro genewskie $i$ Mont Blanc. Gdyby moja siostra byla rozwiedziona, może by poszla za Malczewskiego, który sobie tego życzyt. Jakkolwiek bądź, gdy się ten związek rozszedt stetryczat Malczewski, a to tym bardziej że nie miat już z czego się utrzymać. Czy kiedy wrócit pierwej na Wotyń nim przybyt do Warszawy? Nie pamiętam ${ }^{44}$.

Józef Ujejski również w swoim wprowadzeniu do Marii pisał, że Malczewski ten związek „mocno odcierpiał”. Otwartą pozostaje kwestia, czy Antoni, będąc tak bardzo zakochanym i do tego pragnąc małżeństwa, mógł w tym czasie wdać się $\mathrm{w}$ romans $\mathrm{z}$ domniemaną Julią Jakubowską. Jeszcze $\mathrm{w}$ grudniu 1816 roku napisał on utwór $w$ języku francuskim poświęcony damie swego serca pt. Portrait de la petite Ida, w którym ukazał miłosny obraz Franciszki. Warto zauważyć, że nie zachował się żaden podobny utwór adresowany do innych kochanek Malczewskiego. Portret ldalki jest świadectwem głębszego uczucia niż zwykłą salonową „grą piśmienną". Stanowi wyznanie bezgranicznej miłości: „kiedy się kocha odmiennie, tak jak w świecie nie należy kochać"45.

Wątek romansu Malczewskiego z Franciszką poruszył także Konstanty Gaszyński w swoim artykule Nieznane szczegóty z życia $A$. M., opublikowanym na łamach „Czasu” w 1856 roku. Stwierdzał w nim, że kiedy autor Marii bywał „miłym i pożądanym gościem” u Jabłonowskiego, „nowa znów uwięziła go miłość. Przedmiotem jej była Polka księżna L..., którą nawet miał poślubić, ale los chciał inaczej. Małżeństwo to już bardzo bliskie, rozchwiało się"46. Aby nie rozstawać się z nią na dłużej, Antoni porzucił dobrze zapowiadającą się karierę urzędniczą i mimo braku pieniędzy towarzyszył ukochanej w zagranicznych podróżach. Było to pierwsze uczucie, w które tak mocno zaangażował się po nieudanym związku ze swoją poprzednią miłością - siostrą stryjeczną Anną.

Zakochany Malczewski spędził $w$ towarzystwie Franciszki prawie cały 1815 rok, a później udali się oboje w podróż po Europie. W drugiej połowie marca 1816 roku, jak podaje Halina Gacowa ${ }^{47}$, autor Marii wyjechał do Szarogrodu i spędził tam kilka tygodni w celu podjęcia znacznej kwoty na dobrach Henryka Lubomirskiego oraz sum posagowych Franciszki Lubomirskiej. Natomiast początkiem lata tego samego roku, jak precyzuje Antoni Rolle ${ }^{48}$, nastąpił ich wspólny wyjazd za granicę - w pierwszej kolejności do Drezna, gdzie zostali aż do zimy. Karol Załuski, przebywający od 1816 roku w Szwajcarii, stwierdził, że jego siostra „dla poratowania zdrowia bawiła w Dreźnie"49. Czyżby właśnie tam urodziła Jakubowskiego? Wiadomo, że przez następne miesiące Malczewski i Franciszka byli nierozłączni. Lato 1817 roku spędzili wspólnie w Szwajcarii nad brzegiem

\footnotetext{
11 A. Malcze wski, Maria, Sanok 1855 , s. IX.

1: Cyt. za: M. De r n a low i c z, Antoni Malczewski, Warszawa 1967, s. 94, Ludzie Żywi, 13.

th K. G a s z y ń s k i, Kilka nowych szczegótów o Antonim Malczewskim, „Czas” 1856, nr 68, s. 2.

H. G a c ow a, op. cit., s. 220.

14 A. J. Roll e, Rodzina Malczewskiego, 2010, s. 222, Klasyka.

${ }^{14} \mathrm{~K}$. Z a lus k i, W'spomnienia o Rodzinie Zaluskich w XIX stuleciu, Kraków 1907, s. 18.
} 
jeziora Leman, gdzie była żona Lubomirskiego po dziesięciu latach rozłąki spotkała się z bratem Karolem. Na przełomie września i października para udała się do Włoch, skąd najprawdopodobniej wyjechali do Francji, co potwierdza relacja Januszewskiego ${ }^{50}$. Autor Wspomnień rodziny Załuskich $w$ XIX stuleciu notował wizytę swojej siostry na wyspach Hyères. Halina Gacowa podejrzewa, że w tej podróży również towarzyszył jej Malczewski ${ }^{51}$.

O bliskiej znajomości pary pisała także Maria Dernałowicz w książce Antoni Malczewski, w której podkreślała, że autor Marii mimo całego swojego uroku nie był najlepszym kandydatem na męża dla panny z wyższej sfery. Podobnie wypowiadał się Lucjan Siemieński w tekście zamieszczonym w „Przeglądzie Lwowskim" w 1872 roku:

Pozwolę sobie uchylić zastonę, aby zajrzeć w rzeczywiste położenie poety.

Wiadomo, ze Malczewski kilka lat przepędzit za granica: zwiedzit Niemcy, Wtochy, Szwajcarię. Pociagnęta go tam sktonność wyższego umystu pragnącego się wyksztatcić, nauczyć, przypatrzyć z bliska daleko posuniętej cywilizacji, lecz obok tego miała go pociagnąc za soba pani znakomitego rodu, fortuny i wdzięków, która zwyczajem światowych dam wybrata się w kilkoletni wojaż... Malczewski przytaczyt się do jej towarzystwa, co dogadzato obojgu: czuli bowiem wzajemna skłonność ku sobie, skłonność, której nic nie przeszkadzato uwieńczyć się związkiem matzeńskim, gdyby, jak jedni utrzymuja, nie zaszły jakieś przeszkody czy względy familijne; a jak drudzy, ze w decydującej chwili zawahata się piękna pani, która przy świetnym imieniu i tytule, nie chciała rozstać się ani z imieniem, ani $z$ tytutem, co byto nieuniknionym przy oddaniu ręki mitemu, wyksztatconemu, zakochanemu na zabój, lecz bez majątku i bez sławy kawalerowi.

Być może, że światowa dama, wychowana w konwencjonalnym rygorze, zbyt uważajaca na te delikatne granice, poza które uczuciom nawet wybiegać nie wolno, przelękta się tych burz namiętnych, jakimi wrzata pierś poety... Byt on nim, choć się jeszcze nie objawit. Ekstatyczny rodzaj mitości zazwyczaj przestrasza istoty lekkie i rozrzucone, lubiące bawić się z płomieniem, lecz nigdy w nim piórek nie spalić.

Malczewski ubóstwiat ja do szaleństwa...

Zdarzyło mi się czytać jego ręką skreślony, lecz w języku francuskim jej portret moralny; prześliczny pastel nawiany pyłkami barw; wypieszczony tymi dojrzanymi tylko oku kochanka odcieniami niewieściego charakteru, które krzyżując się $z$ cieniami kontrastów, nadawaty catej fizjonomii wyraz nieopisanego uroku...

Takim malarzem nie mógt być kto inny, tylko ten, co duszę swą przelat w przedmiot stuzacy mu za wzór do malowidta.

Wiemy z żywota poety, jako wróciwszy z zagranicy, wziąt dzierżawę na Wotyniu, zakopat się na wsi $i$ caty oddat sie pracom umystowym.

Jeżeli wolno robić domysty i zgadywać, jaka myśl zaprzatała mu głowę w tym nowym okresie, powiedziatbym, że po doznanej klęsce na polu mitości, usunąt się na bok, aby zebrać ducha i pokrzepić sity umystowe do nowego zawodu, w którym

(x) T. Ja nus ze ws ki, Z życia Antoniego Malczewskiego, „Dziennik Literacki” 1852, nr 4, s. 27.

51 H. Ga cowa, op. cit., s. 225. 
miat zdobyć to, czego mu nie dostawało do równoważenia świetności rodu, majątku i tytutu osoby ukochanej $j^{52}$.

Możliwe, że pochodzenie Jakubowskiego było swoistą tajemnicą poliszynela, ale dochowano surowo dyskrecji ze względu na znaczenie obu rodów: Załuskich i Lubomirskich. Nie dziwi zatem fakt, że we Wspomnieniach o rodzinie Załuskich $w$ XIX stuleciu spisanych przez Karola, brata Franciszki, nie ma ani słowa o romansie pary. Pojawia się zaledwie jednozdaniowa wzmianka o Malczewskim ${ }^{53}$. Książka ta jest ciekawym pamiętnikiem rodzinnej historii, ale nie zawiera żadnych informacji potwierdzających ani wykluczających nową hipotezę.

Warto zauważyć, że w tamtych czasach sama Izabela Czartoryska miała na swoim dworze córkę, Cecylię Beydale ${ }^{54}$, która oficjalnie występowała jako jej kuzynka. Niewykluczone, że August Antoni został oddany na wychowanie Jakubowskim (będącym być może oficjalistami w służbie Załuskich), którzy dali dziecku nazwisko. Hipoteza ta wyjaśniłaby stwierdzenie Rosienkiewicza z Wiadomości biograficznej, że poeta „sądził się być pozbawionym rodziców”, a ukochaną matkę poznał dopiero $w 10$. roku życia.

Zastanawiający jest również fakt, że August Antoni, wymieniając w The $R e-$ membrances of a Polish Exile najważniejsze instytucje kulturalne w Polsce, wspominał przede wszystkim o zasługach rodu Załuskich jako założycielach słynnej biblioteki:

Istniata $w$ Warszawie wielka $i$ wspaniata biblioteka, dar rodziny Załuskich dla społeczeństwa, znana pod ich imieniem. Zniszczono ją niemal doszczętnie jak tę w Aleksandrii ${ }^{55}$.

Weryfikacja tej hipotezy wymaga dalszych badań, ale nie jest niemożliwa, gdyż być może istnieją dokumenty związane $z$ dzieciństwem i krzemieniecką edukacją Jakubowskiego, które przetrwały w archiwach Uniwersytetu Kijowskiego.

W świetle nowych ustaleń można dokładnie usytuować w czasie najważniejsze fakty z życia Jakubowskiego w Ameryce, będące dotąd przedmiotem spekulacji. Dysponujemy tekstem kazania doktora Sprague'a, wygłoszonego 11 maja 1834 roku do 26 uchodźców z pokładu „Hebe”, którzy wraz z Jakubowskim byli obecni w tym dniu w kościele. To właśnie w doktorze Sprague'u odnalazł młody poeta protektora i pierwszego wydawcę swoich utworów. Julian Maślanka pisał,

52 L. S i e mieńs ki, Kilka myśli o Antonim Malczewskim i jego „Marii”, "Przegląd Lwowski” 1872 , t. 4 , s. 348 .

33 K. Załuski, op. cit., s. 17.

in Jej ojcem był najprawdopodobniej Kazimierz Rzewuski, pisarz polny koronny. Izabela Czartoryska wyznala prawdę o rzeczywistym pochodzeniu swojej córki dopiero, gdy Cecylia chciała wziąć ślub z Konstantym Adamem Czartoryskim, który był jej przyrodnim bratem. Por. G, Pa u sze r - K I o n ow sk a, Pani na Pulawach, opowieść o Izabeli z Flemmingów Czartoryskiej, Warszawa 1978, s. 244-255.

W oryginale: There was a large and rich library in W'arsaw; the gift of the family of Zaluski to the public, which was known by its name. It was ravaged almost like that of Alexandria, A. A. Jakubowski, The Remembrances..., s. 36. 
iż Jakubowski przez prawie dwa lata pracował jako nauczyciel języka francuskiego w Stockbridge ${ }^{56}$. Badacz powoływał się $w$ tej kwestii na artykuł Colemanów, w którym stwierdzono, że August Antoni dzięki wstawiennictwu Sprague'a uczył w prestiżowej Sedgwick School. Jednak szkoły o nazwie „Mrs. Charles Sedgwick's School for Girls" nigdy nie było w Stockbridge ani w Albany. Mąż Elizabeth Buckminster Dwight Sedgwick (blisko spokrewnionej z późniejszą pracodawczynią Jakubowskiego w Northampton, Margarette Dwight) - Charles Sedgwick przeniósł się w 1828 roku ze swego rodzinnego Stockbridge niedaleko Lenox i tam otworzył żonie słynną, najlepszą wtedy w Stanach Zjednoczonych szkołę dla dziewcząt. Jakubowski pracował zatem w Lenox, a nie w Stockbridge. Dodatkową ciekawostką i być może wytłumaczeniem, dlaczego zaoferowano Jakubowskiemu tam zatrudnienie jest fakt, że długoletnim służącym ojca Charlesa, czyli Theodora Sedgwicka, był Agrippa Hull - słynny ciemnoskóry ordynans Tadeusza Kościuszki podczas wojny rewolucyjnej w Stanach Zjednoczonych. Polska była więc całkiem bliska rodzinie Sedgwicków, gdyż Hull szczycił się swoimi koneksjami z Tadeuszem Kościuszką.

Dzięki Annual Catalogue of the the Teachers and Scholars in the Gothic Seminary $\mathrm{z}$ lat 1836 i 1837 oraz informacjom pochodzącym ze sprowadzonej ze Stanów Zjednoczonych książki Yankee Family, nie ma żadnych wątpliwości co do spornej kwestii, kiedy Jakubowski wybrał się w odwiedziny do swojego wuja - Konstantego Malczewskiego, rodzonego brata Antoniego. Miało to miejsce na przełomie 1834 i 1835 roku lub najpóźniej w lecie 1835 roku. Kluczowym dokumentem jest tutaj nekrolog z „Daily Hampshire Gazette”, który wyraźnie stwierdza, że Jakubowski pojechał do stryja wkrótce po wydaniu pierwszego tomiku The Remembrances..., a po powrocie do Nowego Jorku i chorobie, która "do śmierci objawiała się urazem kręgosłupa", pracował przez około rok w Miss Dwight's Seminary.

Światło na życie poety rzuca także sprowadzony przeze mnie z Biblioteki Polskiej w Paryżu fragment powieści Jakubowskiego pt. Major Aleksander, który nie został wcześniej wydany. Żadnemu z badaczy nie udało się też natrafić na jakąkolwiek wzmiankę o Dziejach literatury stowiańskiej, o których wspomina Estreicher w swojej bibliografii. Według niego Jakubowski wydał je w 1837 roku w Albany, jednak $w$ znanych nam świadectwach i publikacjach wydawanych $w$ tamtych czasach nie ma śladu jej istnienia. Możliwe, że jest to swoista literacka legenda, gdyż Estreicher nie odnotował angielskiego tytułu dzieła.

Poszukiwania dotyczące życia i twórczości Jakubowskiego ciągle trwają. Do dziś nie dysponujemy żadną podobizną poety. Można mieć jednak nadzieję, że portret Malczewskiego z synem, o którym pisał Zbigniew Dębicki w „Kurierze Warszawskim"57, naprawdę istniał i być może kiedyś się odnajdzie. Jeden z oddziałów Muzeum Historycznego w Northampton posiada kolekcję kilkuset nieskatalogowanych obrazów, które należały kiedyś do Gothic Seminary. Kto wie, czy na jednym z nich nie utrwalono właśnie Augusta Antoniego Jakubowskiego?

57 Por. Z. D ę b i ck i, Syn Malczewskiego, „Kurier Warszawski” 1930, nr 93, s. 6. 



\section{August Antoni Jakubowski - biografia poety rozpaczy}

Badacze wysuwali różne hipotezy dotyczące daty urodzenia Augusta Antoniego Jakubowskiego. Do niedawna słuszne wydawało się przypuszczenie Stanisława Pigonia i Juliana Maślanki, że przyszedł on na świat w 1814 roku. Jednak po zapoznaniu się z amerykańskimi źródłami pochodzącymi z miejsca wygnania pisarza, do których wspomniani uczeni nie mieli dostępu, możemy przypuszczać, że Jakubowski urodził się w 1816 roku. W wyciągu z aktów zgonów w Northampton napisano bowiem przy dacie śmierci Jakubowskiego 24 kwietnia 1837 roku, że przeżył 21 lat $^{58}$. Potwierdza je również napis wyryty na grobie poety ${ }^{59}$, a także przedmowa z 1835 roku do dzieła Jakubowskiego pt. The Remembrances of a Polish Exile, napisana przez dra Sprague'a. Duchowny podkreślił w niej, że młody autor liczył sobie wówczas 19 lat ${ }^{60}$. Sprague znał poetę od początku jego pobytu w Albany i otoczył go troskliwą opieką. Wydaje się oczywiste, że Jakubowski miał wgląd w publikację przed drukiem i osobiście udzielił protektorowi informacji o sobie. Dwa lata później na jego nagrobku w Northampton umieszczono napis, że przeżył 21 lat.

Natomiast w źródłach polskich emigrantów pojawiają się niewielkie rozbieżności, najprawdopodobniej wskutek dystansu czasowego. Paweł Sobolewski, najmłodszy zesłaniec do Ameryki (urodzony w 1818 roku), płynący jedną fregatą z poetą, w swojej antologii Poets and poetry of Poland zaznaczył, że Jakubowski miał 22 lata, kiedy zmarł' ${ }^{61}$. Swój tekst napisał jednak blisko 50 lat po tajemniczej śmierci poety, a więc dokładna data mogła nieco zatrzeć się w pamięci autora. Niemniej sytuuje się ona bardzo blisko roku narodzin wskazanego w niniejszej książce. Wspomnienia Sobolewskiego są tym bardziej wiarygodne, że wychowywał się on razem z synem Malczewskiego na Podolu i z nim też podzielił los wygnańca.

in "Jakabowski, Antonius Augustus - from Poland - teacher of French in the Gothic Seminary - 4/24/1837 - aged 21", [w:] Http://files.usgwarchives.net/ma/hampshire/towns/northampton/ vitals/death001.txt, 15 IV 2013.

59 Na nagrobku, którego zdjęcie znajduje się w aneksie, zamieszczono informację, że Jakubowski umarł w wieku 21 lat.

(4) A. A. Ja kub ow k ki, The Remembrances..., s. 8.

61 P. S ob ole w ski, Poets and Poetry of Poland. A collection of Polish verse, including a short account of the history of Polish poetry, with sixty biographical sketches of Poland's poets and specimens of their composition, Chicago 1881, s. 458. 
Z kolei w Wiadomości biograficznej, mającej być wstępem do niezrealizowanego I wydania wierszy poety w 1839 roku, pojawia się informacja, że Jakubowski zmarł w wieku „niespełna 20 lat”. Tekst ten został napisany przez innego zesłańca do Ameryki - Marcina Rosienkiewicza, który przed powstaniem listopadowym pracowal jako nauczyciel $w$ Liceum Krzemienieckim. Jednak w zasadność tych słów wątpił już Julian Maślanka, podkreślając, że Rosienkiewicz był dużo starszy od przyjaciela i należał do innego pokolenia.

Rok 1816 jako czas narodzin Jakubowskiego potwierdzają również wydarzenia z życia jego ojca. Antoni Malczewski po 11-miesięcznym oblężeniu twierdzy w Modlinie bawił w 1814 roku na Wołyniu. Cieszył się tam dużą popularnością i był wręcz rozchwytywany przez towarzystwo. Wiadomo, że miał powodzenie u kobiet - „Kochał się wiecznie, a wszystkie kobiety szalały za nim” - pisał Załuski do Gaszyńskiego ${ }^{62}$. Poeta, po tym, jak otrzymał wojskowy urlop, wrócił na Podole również w 1815 roku, gdzie przebywał od 28 lipca do listopada ${ }^{63}$. Wtedy też zdobył serce tajemniczej damy (najprawdopodobniej Franciszki Marii Lubomirskiej z domu Załuskiej) i wdał się z nią w romans, którego owocem był prawdopodobnie właśnie August Antoni. Doktor W. B. Spraque w przedmowie do Wspomnień polskiego wygnańca podkreślał, że ich autor należy do bardzo szanowanego rodu w jego ojczyźnie i otrzymał gruntowną edukację. Zachwycał się nie tylko umiejętnościami lingwistycznymi i niezwykłą pamięcią, ale także ujmującym charakterem młodzieńca. We wszystkich zachowanych świadectwach na temat poety pojawiają się wzmianki o jego wyjątkowej osobowości. Duchowny podkreślał zalety, takie jak: szlachetna postawa, serdeczność i niezmienna uprzejmość w stosunku do wszystkich spotkanych osób, zjednująca mu ich przyjaźn i szacunek. Także Marcin Rosienkiewicz wspominał, że obyczaje Jakubowskiego były „tak czyste (...), że sobie pozyskał powszechną miłość nie tylko swych rodaków (...), ale i Amerykanów"64. Nawet Paweł Sobolewski po blisko półwieczu od śmierci pisarza zaznaczał, że „posiadł on szlachetność charakteru i dobroć usposobienia tak rzadko spotykane"65. Być może dochodziła do tego również ujmująca powierzchowność. Jak już wspomniałam, obecnie nie dysponujemy żadną podobizną Jakubowskiego, wiadomo jedynie, że Wiktor Gomulicki miał w swoich zbiorach portret Malczewskiego z synem, który jednak zaginął ${ }^{66}$. Sam fakt istnienia takiego obrazu dowodzi, że autor Marii nie wyparł się swojego potomka. August Antoni poznał ojca w wieku 10 lat, jak pisał Rosienkiewicz. Rzeczywiście, w latach 1822-1825 Malczewski wrócił na Wołyń po kilkuletniej podróży po Europie. Paweł Sobolewski w Poets and Poetry of Poland... zaznaczał, że jego przyjaciel był dumny $\mathrm{z}$ bycia krewnym Malczewskiego ${ }^{67}$.

\footnotetext{
62 M. Dernalowicz, op. cit., s. 73.

6.3 H. Ga cowa, op. cit., s. 217.

(n) M. Rosienkiewicz, Wiadomośc biograficzna..., s. 69.

65 P. Sobole ws ki, op. cit., s. 458.

th Z. Dębicki,op. cit., s. 6.

6. P. S ob ole w ski, op. cit., s. 458.
} 
Również za oceanem szczycił się swoim pochodzeniem, o czym świadczy napis na jego nagrobku w Northampton, gdzie herb i nazwisko ojca zostało zapisane jako pierwsze. Nigdzie nie znalazłam żadnej wzmianki świadczącej o tym, że Jakubowski chował urazę do ojca. W utworach młodego poety widać fascynację jego twórczością, jednak bezpośrednio wspomina swojego rodzica tylko raz w Essay on Polish Poetry, gdzie omawiając Marię jako arcydzieło mogące konkurować z utworami Mickiewicza, podkreślił: „To wielka szkoda, że Malczewski pisał tylko dla zabawy, mało się przykładał do literatury. Choć napisał tylko to dzieło, pozostanie ono wiecznym pomnikiem jego chwały"68. Julian Maślanka podejrzewa, że najprawdopodobniej takie wyobrażenie Malczewskiego zawdzięczał Jakubowski matce, którą "nad życie ubóstwiał"69. Zapamiętała ona swojego kochanka jako kogoś lekko sięgającego po pióro dla zapewnienia sobie rozrywki. Zapewne właśnie na jego cześć syn otrzymał swoje drugie imię. Również w 19 tomie Polskiego Stownika Biograficznego możemy przeczytać, że „świadectwa współczesnych zgodnie utrzymują, że ani w Krzemieńcu, ani w okresie swej służby wojskowej M. niczym nie zapowiadał przyszłego autora Marii. Nieliczne utwory, które zachowały się z tych czasów (...) mają charakter albo ćwiczeń szkolnych, albo są wynikiem zabawy towarzyskiej (...), do których ani jego otoczenie, ani on sam nie przywiązywał większej wagi"70.

Za pewne miejsce pochodzenia Augusta Antoniego możemy natomiast uznać Podole, o czym świadczą nie tylko biograficzne wiadomości z życia Antoniego Malczewskiego. W nekrologu Jakubowskiego opublikowanym przez Rosienkiewicza w „Młodej Polsce” w 1838 roku czytamy, że młody poeta był „rodem z Podola"71. Również wspominający go na ostatniej karcie swojej antologii Paweł Sobolewski, który dorastał w tym samym regionie, potwierdzał, że właśnie stamtąd wywodził się twórca Poezji $i^{72}$. Obraz Ukrainy, a szczególnie Podola jako na zawsze utraconego domu rodzinnego, często powraca nie tylko w lirykach Jakubowskiego, ale również we Wspomnieniach... Autor poświęcił Podolu jeden rozdział swojej pracy, a siebie w przedmowie The Remembrances... przyrównywał do wędrownego ptaka, bezskutecznie poszukującego nieba południa.

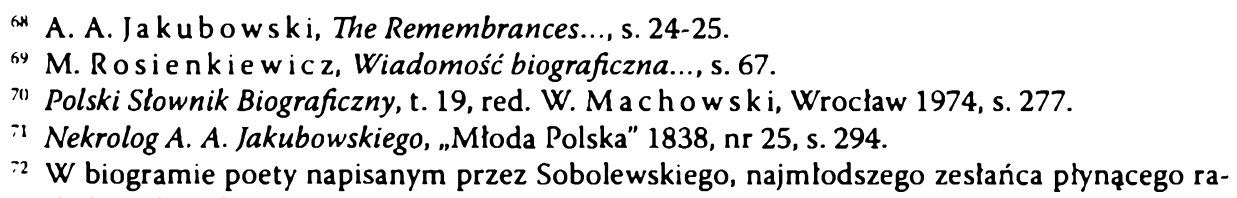
zem z Jakubowskim do USA, możemy przeczytać, że wspólnie wychowali się na Podolu, byli więzieni w Brnie, a potem w Trieście. Według niego Jakubowski po przybyciu do Ameryki mial pracować jako nauczyciel w Stockbridge, a później odwiedzić swego stryja. Pojechał do Meksyku specjalnie po to, by poznać brata ojca, generala armii meksykańskiej, który nie przyjąl go tak, jak się spodziewal. Nie mogąc znieść trudów tulaczki, zalamal się psychicznie i odebrał sobie życie w wieku 22 lat [sic!]. Autor antologii wspominał, że Jakubowski tworzył „przygodnie wiele utworów o wielkiej piękności poetyckiej", a niektóre z nich przelożył i ogłosił w The Remembrances of a Polish Exile. Por. P. So b ole ws ki, op. cit., s. 458 . 
Z całą pewnością można również stwierdzić, że Jakubowski uczęszczał, tak jak jego ojciec, do Liceum Krzemienieckiego i podobnie jak on nie ukończył wszystkich etapów edukacji. Malczewski przed zaliczeniem pierwszego roku ostatniego kursu wyjechał do Warszawy, gdyż marzyła mu się kariera wojskowa, natomiast naukę Jakubowskiego przerwało powstanie listopadowe, które - jak podawał Rosienkiewicz - na zawsze oddzieliło go od rodziny ${ }^{73}$. $Z$ jego relacji wynika jednak, że nie brał bezpośredniego udziału w walkach ze względu na młody wiek. Wiadomo, że w maju 1833 roku Jakubowski znalazł się we Lwowie, co zaznaczył w swoim buntowniczym sonecie Apoleus, przesyconym pragnieniem zemsty na zaborcach po klęskach zrywów narodowych. Obawiając się kolejnych rewolucji, Austria pod naciskiem Rosji zaostrzyła swą politykę wobec powstańców. Jej ofiarą padł również syn Malczewskiego. Stąd we wspomnianym wierszu padają ostre inwektywy:

Nikczemny Wiednia orle, znowu skrzydta swoje

$Z$ carskim ptakiem zlaczyteś - leć na krwawe boje,

Ale cię $w$ drodze piorun mej zemsty uderzy ${ }^{74}$.

W napisanym miesiąc później liryku pt. Pożegnanie. Improwizacja dominuje już nie tylko brak nadziei na pomszczenie ojczyzny, ale na odzyskanie niepodległości i jakiegokolwiek osobistego szczęścia. Najprawdopodobniej wiersz ten powstał wkrótce po aresztowaniu poety. Wskazuje na to m.in. metafora lotu „ptaka w okowach", a także stworzenie sytuacji lirycznej jako pełnego rozpaczy pożegnania $z$ najbliższymi. Towarzyszy mu przeczucie wiecznej rozłąki i definitywne zamknięcie etapu radosnych nadziei, gdyż jak pisał Jakubowski: „serca mego uczta się skończyła"75. Nie wiadomo, czy słowa te skreślił jeszcze w więzieniu we Lwowie, czy może w Brnie na Morawach albo w Trieście nad Adriatykiem, do którego musiał dojść pieszo pod ścisłą strażą.

W tym czasie odbyło się spotkanie trzech zaborców w Münchengratz, gdzie podjęto decyzję o deportacji do Stanów Zjednoczonych grupy więźniów, w tym Jakubowskiego. Młody poeta po trzymiesięcznym areszcie w Brnie, czekając następne trzy miesiące na rozstrzygnięcie swego losu, był pełen najgorszych obaw i przeczuć. W coraz mroczniejszym i posępniejszym tonie tworzył kolejne utwory, takie jak: Dumka Podolanina i Dzwon wieczorny, opatrzone datami. W pierwszym z nich autor nazywał siebie wygnańcem i zaznaczał "umarłych marzeń ślad". Powracał w nich motyw pożegnania, a także uwidaczniała się pewność śmierci. Natomiast $w$ drugim liryku pierwszy raz $w$ poezji Jakubowskiego pojawiła się metafora "robaka straty". Powróci ona w chwili największego kryzysu duchowego poety, gdy wyzna $z$ rozpaczą: „kwiat mego życia zjadłe stoczyły robaki”, co nasuwa związek z fatalistycznym motywem z pieśni Pacholęcia w Marii. Poeta czuł się coraz bardziej osamotniony, najprawdopodobniej nie miał żadnego kontaktu

${ }^{73}$ M. Rosien ki e wi c z, Wiadomość biograficzna..., s. 67.

7 A. A. Jakubowski, Poezje, s. 9.

75 Ibidem, s. 25. 
z bliskimi, stąd zadręczał się przeczuciem, że dzwon wieczorny, słyszany w celi, być może bije na zgon matki albo ukochanej.

Powody aresztowania i zarys sytuacji panującej wówczas w Galicji przedstawił Jakubowski w swoim eseju The Causes of the Emigration of the Poles zamieszczonym we Wspomnieniach... Możemy w nim przeczytać, że po działaniach partyzantki Zaliwskiego rząd Austrii zaniepokojony rozruchami wydał rozkaz natychmiastowego opuszczenia Galicji przez wszystkich polskich emigrantów. Ci, którzy, tak jak Jakubowski, sprzeciwili się rozporządzeniu, zostali „siłą oręża" wydarci z domów przyjaciół i pod eskortą przetransportowani do Brna na Morawach $^{76}$. Polacy czekali tam na paszporty do Francji, które miały pochodzić z Wiednia. Byłoby to dla nich najbezpieczniejszym rozwiązaniem, gdyż Francja jawiła się poecie jako serce rewolucji i liberalnych poglądów, a także najlepsze schronienie dla pragnących walczyć o wolność ojczyzny. Szybko jednak jego nadzieje zostały rozwiane, gdyż rząd wbrew wcześniejszym obietnicom postawił ich przed ultimatum: powrót do Rosji albo wyjazd do Ameryki. Poeta tak wspominał tamte chwile:

Our hearts trembled to leave all our hopes in Europe, to be unable to share the hardships of war with our compatriots, in the resurrection of Poland. The struggle was painful, but our resolution was soon taken. We determined rather to cross the ocean than return to a country that was no more ours? ${ }^{77}$.

W akcie sprzeciwu Jakubowski nie podpisał dokumentów, że jego decyzja jest dobrowolna. Dramatyczne losy zesłańców ukazuje kazanie doktora Sprague’a, którym powitał grupę polskich wygnańców (w tym Augusta Jakubowskiego) w Albany. Opowiadał on o prawie trzyletniej bohaterskiej walce Polaków przeciwko przeważającej sile Rosjan, zakończonej klęską. Wspominał o tym, jak zakuci w łańcuchy, niczym zbrodniarze, byli odsyłani do kolejnych więzień. Podkreślił, że zanim dotarli do Ameryki, doznali wszystkich możliwych cierpień oprócz śmierci ${ }^{78}$.

Syn Malczewskiego urywa opis swojej historii na wyjeździe do więzienia w Trieście, gdzie przebywał do 22 listopada 1833 roku. Stamtąd trafił do pierwszego transportu do Ameryki jako 66. pasażer z 234 osób $^{79}$. Jednak dokładniejsze

76 Inny z wygnańców, Julian Juźwikiewicz, który znalazł się na tym samym statku co Jakubowski, wspominal: „Austria (...) po złodziejsku, bo w nocy (...) wtrąciwszy nas na dwie fregaty (...) do Ameryki Północnej Stanów Zjednoczonych odeslała" - por. J. J u ź w i k i e w i c z, Polacy w Ameryce, czyli pamiętnik piętnastomiesięcznego pobytu, Paryż 1836, s. 71.

$\pi$ Tłumaczenie: Nasze serca obawiały się porzucić wszystkie nadzieje w Europie, nie być w stanie dzielić trudów wojny z naszymi rodakami o zmartwychwstanie Polski. Walka była bolesna, ale szybko podjęliśmy decyzję. Postanowiliśmy raczej przepłynąć ocean, niż powrócić do kraju, który nie byl już więcej nasz.

is W. B. S p rague, A sermon preached in the second presbyterian church, Albany, Sabbath Evenining, May 11, 1834. And repeated, by special request, on the ensuing Tuesday evening in the second reformed dutch church, In behalf of the Polish Exiles lately arrived in this country, Albany 1834, s. 11.

"9 Relację Jakubowskiego potwierdzają również wspomnienia innych wygnańców. Por: J. Juźwikiewicz, op. cit., s. 5-6. 
itinerarium podróży ${ }^{80}$ odbytej na statku „Hebe"81, a trwającej aż 128 dni wyłania się z wierszy Jakubowskiego będących przejmującym zapisem stanu ducha poety coraz bardziej oddalającego się od ojczyzny. Dzięki datom i miejscom pobytu zapisanym przez niego pod konkretnymi utworami możemy z całą pewnością stwierdzić, że w tym czasie powstały wiersze, takie jak: Pożegnanie (2 grudnia 1833 roku na Morzu Adriatyckim), Burza (9 stycznia 1834 roku, między Sycylią a Sardynią), Dumanie I (5 lutego 1834 roku, Gibraltar). Natomiast liryk Bonaparte, uznany przez Sobolewskiego za najbardziej reprezentatywny i umieszczony w jego antologii pod nazwą Ode to Napoleon, powstał zapewne w okolicach lutego, gdyż poeta opatrzył go jedynie dopiskiem: Gibraltar. Ze względu na podobny nastrój, a także powtarzające się charakterystyczne wątki marynistyczne, bardzo prawdopodobne, że w tym czasie poeta napisał również wiersze: Fantazja i Tułacz. Być może do tej grupy należy także liryk Nad morzem, będący profetyczną kontynuacją Burzy, przełamaniem dotychczasowego poczucia bezsilności i zapowiedzią zemsty. Wspomniane wyżej utwory są bowiem utrzymane $w$ tonie rezygnacji i oczekiwania na nieuchronną klęskę.

234 zesłańców, którzy 28 marca 1834 roku przybyli do Nowego Jorku, zapoczątkowało „zbiorową, masową emigrację polityczną do Stanów Zjednoczonych Ameryki"82. Wygnańcy płynący na statkach „Hebe” i „Guerriera” nie tylko stanowili najliczniejszą grupę udającą się do Nowego Świata, ale do historii przeszli jako twórcy pierwszej polskiej organizacji w Ameryce - Komitetu Polskiego. Jego głównym zadaniem było reprezentowanie interesów emigrantów wobec rządu, a jednym z członków organizacji został Marcin Rosienkiewicz. Kiedy Polacy 1 kwietnia 1834 roku opuszczali fregaty, nie spodziewali się życzliwego przyjęcia. Minęły już bowiem trzy lata od „mody na Polskę", trwającej do upadku powstania listopadowego, kiedy organizowano składki dla walczących (w sumie komitety zebrały na ten cel ok. 5,5 tys. dolarów). Skończyły się też manifestacje popierające polski zryw niepodległościowy. Tym razem Amerykanie licznie przybyli do portu bardziej z ciekawości niż z chęci niesienia pomocy. Także i przy tej okazji przeprowadzono zbiórki pieniędzy na potrzeby wygnańców, ale zgromadzone środki nie były wysokie. Prezydent Jackson przywitał naszych rodaków zimnym oświadczeniem, że „fundusze utrzymania się leżą we wszystkich rękodzielniach i kunsztach tego kraju, które są dla każdego otwarte"83. Smutny los czekał większość Polaków, którzy ze względu na swoje szlacheckie pochodzenie nie mieli wyuczo-

80) Była to niezwykle niebezpieczna podróż w środku zimy, a pasażerowie często przeżywali chwile grozy. Wiadomo, że na fregacie wybuchł duży pożar, a w wyniku burz został zniszczony maszt i ożaglowanie. Statki po prawie 70 dniach dotarły do Gibraltaru. Stamtąd w połowie lutego wyruszyły w dalszą trasę i po 6 tygodniach wpłynęły do portu w Nowym Jorku.

"1 Swoistym chichotem losu staje się zestawienie nazwy fregaty „Hebe”, oznaczającej grecką boginię młodości, z faktem, że podróżujący nią dziewiętnastoletni Jakubowski czul, że jego mlodość i radość życia bezpowrotnie miną.

*2 B. Grzeloński, Polacy w Stanach Zjednoczonych Ameryki 1776-1865, Warszawa 1976, s. 111 .

k.3 Ibidem, s. 112. 
nego zawodu albo nie znali języka angielskiego. Wykorzystywano ich do kiepsko opłacanych, ciężkich, fizycznych prac. Jeden z emigrantów tak opisywał wspólną dolę zesłańców: „równie cierpimy, spotkawszy się, to nasze pierwsze przywitanie:

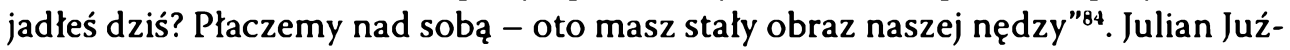
wikiewicz, sam pracujący jako drwal, wspominał o niektórych Polakach w podeszłym wieku, którzy nie mając siły pracować, targnęli się na własne życie ${ }^{85}$. Major Józef Horodyński, pierwszy powstaniec, jaki przybył do Stanów Zjednoczonych, tak podsumował „amerykański sen”: „Nie utrzymałby tu Polaka nawet na łańcuchu, tak nieznośna ta kraina wolności" ${ }^{\prime 66}$.

Do takiego właśnie miejsca przybył młody i wrażliwy Jakubowski, tęskniący za domem i najbliższymi. Już w czasie podróży prześladowały go myśli o śmierci, poeta utwierdzał się w przekonaniu, że nie czeka go nic dobrego na wygnaniu. Razem $\mathrm{z}$ innymi Polakami osiedlił się w mieście Albany. Zapewne uczył się w szkole dla polskich weteranów wojennych, założonej przez Marcina Rosienkiewicza. Młodzieniec zadziwiająco szybko odnalazł się w nowej rzeczywistości. Ku zdumieniu wszystkich, w przeciągu zaledwie 10 miesięcy (od przyjazdu do Stanów Zjednoczonych) tak biegle przyswoił sobie zupełnie obcy mu dotychczas język, że napisał The Remembrances of a Polish Exile. Zdolnościami lingwistycznymi młodzieńca zachwycał się nie tylko Sprague we wstępie do tego dzieła, ale i Rosienkiewicz. Pisał on, że Jakubowski obdarzony był niezwykłą pamięcią, na której wyłącznie opierał się przy pisaniu szkiców historycznych i tworzeniu antologii poezji polskiej, przełożonej na język angielski. Nie miał przy tym dostępu do żadnych naukowych źródeł. Biblioteka Polska w Filadelfii została założona z inicjatywy Rosienkiewicza, który nią zarządzał, ale konkretne zbiory udało jej się zgromadzić dopiero po śmierci syna Malczewskiego. W „Młodej Polsce” z 1838 roku stronę przed nekrologiem Jakubowskiego figuruje podziękowanie Rosienkiewicza m.in. dla Eustachego Januszkiewicza, Juliana Ursyna Niemcewicza i ks. Adama Jerzego Czartoryskiego za „szczodre opatrywanie jej w wybór dzieł polskich i tyczących się Polski"87. August Antoni nie miał szansy z nich korzystać, a mimo to stanął na wysokości zadania i stworzył pierwszą tego rodzaju publikację w Ameryce, a drugą w języku angielskim (po książce Bowringa Speciments of the Polish Poets z 1827 roku).

Życzliwym opiekunem i protektorem młodego poety został autor wstępu do jego dzieła, doktor William Buell Sprague, ceniony duchowny, który uzyskał doktorat trzech prestiżowych uczelni: Yale, Harvardu oraz Columbii, a także przez 40 lat piastował zaszczytną funkcję pastora kościoła prezbiteriańskiego w Alba$n y^{88}$. Nie tylko pomógł mu w wydaniu książki, ale umożliwił pracę w charakterze

"1bidem, s. 115.

*5.5 Wśród nich był ziemianin z Wolynia - Rostowski. Ibidem, s. 116.

"r6 Ibidem, s. 117.

n7 „Mloda Polska” nr 25, 10 września 1838, s. 293.

"M. M. Gie rgielew ic z, August Antoni Jakubowski and his 'Remembrances of a Polish Exile', „The Polish Review” 1971, Vol. 16, No. 2, s. 70. 
nauczyciela języka francuskiego w Sedgwick School. Później Jakubowski uczył również w Seminarium Gotyckim w Northampton, znanym także pod nazwą Miss Dwight's School for Girls, od nazwiska właścicielki Margarett Dwight. Sam budynek już nie istnieje, ale tamtejsze muzeum posiada wiele pamiątek $\mathrm{z}$ tego okresu. Dzięki przedmowie Sprague’a możemy także w miarę dokładnie umiejscowić w czasie wydarzenie, które zaważyło na losie młodego wygnańca. 30 stycznia 1835 roku poeta miał już sprecyzowane plany co do wyjazdu do Meksyku, aby odwiedzić brata swojego ojca - Konstantego Malczewskiego i czynił już ku temu przygotowania.

Kłopoty Konstantego, najmłodszego z rodzeństwa Malczewskich, zaczęły się, gdy poznał on swojego przyrodniego brata Edwarda Haumana, wydziedziczonego przez ojca za swoje wybryki. Miało to miejsce w 1817 roku, kiedy stryj Jakubowskiego był młodym podoficerem wojsk Królestwa Polskiego. Młodzieńców szybko połączył awanturniczy charakter i hulaszczy tryb życia. Wspólnie nie tylko znieważyli rosyjskiego pułkownika Golicyna, ale wyzwali go również na pojedynek. W rezultacie Malczewski szybko został zdegradowany do stopnia szeregowego żołnierza $\mathrm{w}$ piątym pułku piechoty liniowej, stacjonującym w Zamościu. Nie wytrzymał jednak długo na prowincji z dala od towarzyskiego życia. $Z$ pomocą Edwarda sprzedał cały majątek, jaki mu pozostał i pod pozorem załatwienia spraw finansowych dostał urlop, a potem czmychnął aż do Ameryki. Krążyły o nim różne wieści, ale Maria Dernałowicz uważa, że jedynie pewna informacja to tekst opublikowany w lwowskich „Rozmaitościach” z 1835 roku przez Hipolita Oladowskiego. Donosił on, że spotkał w Meksyku rodaka, rodzonego brata niedawno zmarłego poety, który od 19 lat jest w służbie meksykańskiej oraz zmienił zupełnie charakter i sposób życia ${ }^{89}$. Jak daleko sięgała ta zmiana, świadczą słowa Wójcickiego wspominającego, że Konstanty zupełnie zapomniał ojczystej mowy, a z polskiego języka pamiętał tylko jeden wiersz z Barbary Radziwiłówny Felińskiego.

Jakubowski nie mógł pamiętać stryja, ponieważ miał zaledwie cztery lata, kiedy Konstanty wyjechał do Teksasu. Tam jako artylerzysta zakładał fortyfikacje w obozie wojskowym o nazwie Champ d'Asile nad rzeką Trinity. Na liście polskich wygnańców z 1833 roku przy nazwisku Jakubowskiego widnieje wzmianka: „wyjechał do Meksyku do swojego wuja, oficera Wojsk Meksykańskich"90. Był to najczęstszy (obok Francji) kierunek wyjazdu polskich wygnańców przybyłych do Ameryki. Jednak dla Augusta Antoniego okazał się on tragiczny w swoich skutkach. Najszerzej pisał o tym Sobolewski we wspominanej już antologii. Poeta był dumny z bycia synem Malczewskiego i oczekiwał życzliwego przyjęcia ze strony brata ojca. W utworach Jakubowskiego bardzo często powraca motyw tęsknoty za rodakami, rodziną i przyjaciółmi, więc na pewno spotkanie bliskiego krewnego na obcej ziemi było dla niego bardzo ważne. Wiadomo, że wyniosła postawa Kon- 
stantego dotkliwie zraniła młodego ducha poety, który wrócił do Stanów mocno przybity i nigdy nie otrząsnął się z doznanego upokorzenia. Sobolewski nie opisywał dokładnie zachowania brata Malczewskiego, jego postawę zobrazował słowami: „haughty manner"91. Możemy je rozumieć jako bycie próżnym, hardym, aroganckim, wyniosłym czy napuszonym. Okazuje się, że Konstanty nie tylko nie powitał siostrzeńca ojczystą mową, ale i dobrym słowem. Być może nie uznał jego pochodzenia i potraktował jak przybłędę. Prawdopodobnie pozbawił on złudzeń wrażliwego patriotę; znany i lubiany za podtrzymywanie ducha $u$ innych, Jakubowski sam mógł go utracić, nie znalazłszy wsparcia i zrozumienia, kiedy najbardziej ich potrzebował.

Rosienkiewicz podkreślał, że znajomi odradzali mu wyjazd do Ameryki Południowej, jednak August Antoni pozostał nieugięty. „Nie mogąc znieść południowego klimatu i nie doznawszy od swego krewnego przyjęcia, jakiego się spodziewał, wrócił do Nowego Jorku z znacznie nadwerężonym zdrowiem" ${ }^{92}$ - opowiadał jego przyjaciel. Przyczyniło się to do „długiej i ciężkiej” choroby. Rosienkiewicz wspominał o fizycznych skutkach owych dolegliwości, co także zostało opisane w amerykańskim nekrologu poety. Jakubowski został „zdefigurowany garbem”. Dzięki konsultacji z profesorem medycyny, wykładającym na New York University, możemy zdiagnozować chorobę, na którą prawdopodobnie zapadł młody poeta w drodze powrotnej z Meksyku. Według niego była to „Pott's Disease”, czyli tuberculosis spondylitis, zwana też gruźlicą kręgosłupa. Choroba ta bardzo powszechna w wiekach ubiegłych, teraz nieco zanikła $\mathrm{z}$ powodu odkrycia lekarstw antygruźliczych. Garb jest końcowym jej objawem. Malaria, niedobór witaminy D, brak zdrowego jedzenia, wręcz głód przyczyniają się do jej rozwoju i często doprowadzają do śmierci. Dwa miesiące podróży malarycznymi rzekami do ogarniętego wojną meksykańskiego Teksasu i dwa z powrotem, bez pieniędzy na godziwy wikt wystarczyły, aby gruźlica rozwinęła się u Jakubowskiego w tak straszny sposób.

Zadziwiające jest to, że według relacji znajomego nie zrobiło to na Auguście Antonim „najmniejszego wrażenia”. Co więcej, ponoć żartował z siebie, nazywając się Ezopem. Wydaje się jednak, że była to raczej maska zawsze uśmiechniętego i przez wszystkich lubianego „młodego filozofa”, pod którą skrywał prawdziwe uczucia. Niezbity dowód pogłębiającej się depresji stanowią jego pełne rozpaczy wiersze. Pokazują one stopniowe zamknięcie się na świat, utratę wszelkiej nadziei, a w końcu dojrzewanie do śmierci i jej pragnienie. Nie jest to jednak owo pożądanie - Lust im Tode, które zaprowadziło innego samobójcę, Heinricha von Kleista, nad jezioro Wannsee. Jakubowski nie chciał żyć w świecie, który go „zdradził" i pogrzebał jego pragnienia. W utworach poety cały czas zaznacza się kontrast pomiędzy światem wewnętrznym bohatera a zewnętrzną rzeczywistością. Powoli gasły w Jakubowskim wszystkie uczucia - nawet chęć zemsty i buntu, czuł się martwy już za życia. Sobolewski jako główne przyczyny samobójczej śmierci 
podawał "niespełnione aspiracje i zrujnowane marzenia"93 a także wspomniane wcześniej spotkanie z Konstantym Malczewskim. Natomiast w 10 tomie Polskiego Słownika Biograficznego możemy natrafić na zaskakującą informację, że stryj "być może, wspólnie ze swym przyjacielem E. Haumanem, późniejszym wydawcą nowojorskim, otoczył opieką młodego Jakubowskiego i umożliwił druk jego pierwszych utworów"94. Wiadomo, że pierwsze dzieło poety The Remembrances of a Polish Exile zostało wydane dzięki pomocy doktora Sprague'a. Kwestią sporną pozostaje, czy autorom słownika chodziło o kolejne wydania tego dzieła, czy może o domniemane Dzieje literatur słowiańskich, które też przecież miały ukazać się w Albany. Prawdopodobne wydaje się, że Estreicher znał tę pozycję tylko ze słyszenia, skoro podał jedynie polski tytuł publikacji, która przecież pierwotnie miała ukazać się w języku angielskim.

Więcej nadziei wzbudza natomiast wzmianka o synu Malczewskiego, umieszczona w dziele Onufrego Hieronima Kunaszowskiego pt. Życiorysy uczestników Powstania Listopadowego: zebrane na pamiątkę obchodu jubileuszowego pięćdziesięcioletniej rocznicy tego powstania. W rozdziale poświęconym uczestnikom powstania, którzy umarli w Ameryce Północnej od 1834 do 1880 roku, możemy przeczytać, że Jakubowski „miał wiele udatnych poezji, znajdować się mających w ręku Numy Łepkowskiego w Nowym Jorku"95. Łepkowski, choć był dużo starszy od poety (urodził się około 1805 roku), miał wiele wspólnego z Jakubowskim. Nie tylko obaj pochodzili z Podola, ale razem znaleźli się w transporcie do Ameryki. Później ich drogi się rozeszły, August Antoni wyjechał do Albany, a Numa jako nauczyciel muzyki pracował w Nowym Jorku. Niewykluczone, że wspomniane rękopisy nie uległy zniszczeniu i ciągle czekają na znalazcę.

W książce Inscriptions on the Grave Stones in the Grave Yards of Northampton and of other Towns in the Valley of Connecticut umieszczono m.in. napis widniejący na nagrobku Jakubowskiego. Brzmi on tak:

"A Polish Exile"

A. A. Tarnava Malchewski,

vel, Jakubowski,

Obt. 24 Ap. 1837, aged 21.

Erected by his pupils ${ }^{96}$

Epitafium to, specjalnie na potrzeby niniejszej pracy, uwiecznił na zdjęciach mecenas Przemysław Jan Bloch. W rzeczywistości na płycie nagrobnej zapis jest nieco inny:

${ }^{93}$ P. S obole w ski, op. cit., s. 458.

${ }^{91}$ Polski Stownik Biograficzny, t. 10, s. 383.

95. O. H. Kun as zowski, Życiorysy uczestników Powstania Listopadowego: zebrane na pamiątkę obchodu jubileuszowego pięćdziesięcioletniej rocznicy tego powstania, Lwów 1880, s. 87.

${ }_{6}$ Inscriptions on the Grave Stones in the Grave Yards of Northampton and of other towns in the Valley of Connecticut, transl. T. B ridg m a n, Northampton, Massachusetts 1850, s. 100. 
$A$

POLISH EXILE

A.A. TARNAVA

MALCZEWSKI vel

JAKUBOWSKI

Obt. 24 Ap. 1837

AGE 21

[erected by his pupils]

W aneksie do niniejszej książki zamieszczam zdjęcie bardzo dobrze zachowanego grobowca Jakubowskiego w Northampton. Jedynie ostatni wers epitafium jest zasłonięty murawą. Połowicznie tylko spełniły się słowa autora jakże wymownego wiersza Tułacz, w którym pisał:

\section{(...) me imie}

Wkrótce tu zapomniane nikogo nie wzruszy.

W obcej ziemi gdzieś skończę życie me tułacze,

Grób mój nie będzie między groby podolskimi,

Dusza tylko w ojczyźnie, choć proch w obcej ziemi?".

Poeta miał tyle szczęścia w swoim nieszczęściu, że przyjaciółka nie porzuciła go w sposób równie zdradziecki, jak Zofia Rucińska jego ojca. Jakubowski musiał wiedzieć o nędzy ostatnich dni Antoniego Malczewskiego i o tym, że nie wiadomo nawet, gdzie znajduje się jego grób. Choć utwory Augusta Antoniego przez ponad 130 lat pozostawały w zupełnym zapomnieniu, kiedy zostały odkryte, wywołały lawinę nowych poszukiwań i dociekań. Julian Maślanka, podobnie jak wcześniej Stanisław Pigoń, wykonał tytaniczną pracę, aby odnaleźć jak najwięcej przekazów i źródeł wzmiankujących o poecie. Czytając ich artykuły, uzupełnione o odnalezienie The Remembrances of a Polish Exile przez Juliana Krzyżanowskiego, wydawać by się mogło, że mimo luk w biografii pisarza badacze odkryli już wszystko, co możliwe. Na tym jednak historia się nie kończy. Okazuje się, że tragiczna postać i twórczość polskiego wygnańca wciąż fascynuje pasjonatów literatury, którzy na własną rękę szukają jego śladów zarówno w kraju, jak i za oceanem. Dokładają oni wszelkich starań, aby imię Jakubowskiego nie tylko nie zostało zapomniane, ale pragną go lepiej poznać i zrozumieć. Pisząc niniejszą książkę, niemal z każdym dniem poznaję nowe fakty z życia poety oraz jego przyjaciół. Na światło dzienne wychodzą pomyłki w zachowanych przekazach, które skutecznie przez długi czas utrudnialy dotarcie do prawdy.

Marcin Rosienkiewicz na przykład wspominał, że w pogrzebie Jakubowskiego uczestniczyło mnóstwo Amerykanów i tylko jeden Polak, najlepszy przyjaciel poety, Napoleon Kościołowski. W takim brzmieniu nazwisko to przytacza również w swojej pracy Julian Maślanka. Okazuje się, że Rosienkiewicz, który przestawił kolejność imion Jakubowskiego w samym tytule swojego szkicu, pomylił się również w nazwisku jego druha, które w rzeczywistości brzmi Kościałkowski.

${ }^{47}$ A. A. Jakubowski, Poezje, s. 4. 
Niestety, nawet on nie zdołał powstrzymać Jakubowskiego od rozpaczliwego, samobójczego kroku. Jakubowski zabił się „w poranku życia”98 25 kwietnia 1837 roku, jak pisał Marcin Rosienkiewicz. Tę datę podał również w nekrologu przyjaciela opublikowanym w „Młodej Polsce”, którą późniejsi badacze przyjęli za pewnik. Jednak w epitafium na grobie Jakubowskiego i w wykazie aktów zgonów z Northampton można przeczytać, że poeta zmarł dzień wcześniej. Bez wątpienia tragiczna śmierć młodego wygnańca wpisuje się w „porządek klęski” ${ }^{99}$ rodziny Malczewskich.

9k Nekrolog A. A. Jakubowskiego, s. 294.

9y J. La w s k i, Malczewski - iluminacje i klęski melancholijnego wędrowca, [w:] A. Ma l c z e w ski, Maria. Powieść ukraińska, Białystok 2002, s. 74, Czarny Romantyzm. 


\section{Poezje Augusta Antoniego Jakubowskiego}

\section{1. „Pamiętnik duszy” Jakubowskiego odnaleziony po 132 latach}

Dorobek poetycki Jakubowskiego został zebrany i opracowany przez Marcina Rosienkiewicza, który w 1839 roku planował wydać edycję pism pośmiertnych swojego przyjaciela z Liceum Krzemienieckiego. Miał on dostęp do prywatnych notatek syna Malczewskiego. Przepisał z nich 42 wiersze i przetłumaczony przez siebie fragment prozy, które wysłał Niemcewiczowi, aby ten zajął się ich publikacją. Niestety, materiały zaginęły w niewyjaśnionych okolicznościach i dopiero po ponad 130 latach zostały ujawnione przez Juliana Maślankę, który opracował je edytorsko i opublikował w 1973 roku. Po sprowadzeniu do Polski przeze mnie kopii rękopisu Pism pośmiertnych z Biblioteki Polskiej w Paryżu okazało się, że profesor zmienił pierwotny układ utworów, zaproponowany przez Rosienkiewicza. W oryginale przyjaciel Jakubowskiego zamieścił bowiem jego utwory w następującej kolejności:

1. Burza

2. Podole

3. Przeszłość

4. Nad morzem

5. Tęsknota

6. Przemiana

7. Pożegnanie. Improwizacja

8. Dumka Podolanina

9. Dumanie

10. Piosnka Tatarów

11. Rozpacz

12. Czarniecki na Monasterzyskach

13. Dumanie

14. Do J.B.

15. Pożegnanie

16. Dumanie

17. Uniesienie

18. Tutacz

19. Fantazya
20. Sonety:
a) Kamieniec
b) Tutacz
c) Piramidy
d) Do Celiny
e) Ona
f) Aut Brutus Aut Nihil
g) Alopeus
h) Gwiazdka i ja
i) Jesień ( $z$ Lamartina)
j) Przeszłość
k) Wspomnienie i Nadzieja

21. Dumka ukraińska

22. Dumanie

23. Bonaparte

24. Dwie gwiazdki

25. Dzwon wieczorny

26. Epizod z poematu „Bunty Chmielnickiego" 
27. Do...

28. Dumka gminna

29. Ideaty
30. Tryloety

31. Indyanin

32. Indyanka ${ }^{100}$

Trudno wskazać klucz, jakim kierował się Rosienkiewicz, porządkując utwory Jakubowskiego, gdyż nie zostały one ułożone chronologicznie, nie oddają też etapów twórczości młodego poety. Otwierający tomik wiersz Burza pisany był na statku w czasie podróży do Nowego Jorku, natomiast kolejne utwory przeplatają się wybiórczo z różnych okresów jego życia.

Były nauczyciel Liceum Krzemienieckiego w Wiadomości biograficznej przekonywał, że Jakubowski „drugiej ręki” nie położył na swoich wierszach, które miał pisać pod wpływem chwili, nie troszcząc się zbytnio o ich artystyczną formę. August Antoni nie myślał zapewne jeszcze o ich wydaniu, stąd nie ułożył ich w integralną całość. Być może Rosienkiewicz chciał jak najszybciej przesłać Niemcewiczowi opracowaną edycję Pism pośmiertnych, stąd nie nadał im bardziej przemyślanej kolejności. Wydaje się jednak, że zależało mu przede wszystkim na wyraźnym zaakcentowaniu najbardziej charakterystycznych cech i wartości wyróżniających twórczość przyjaciela. Dzięki temu Jakubowski od pierwszych kart poezji jawi się jako wygnane „stepów smętne dziecię"101, owładnięte obsesją śmierci i pesymizmem, przeczuwające, że nigdy już nie powróci na ukochane Podole.

Natomiast Julian Maślanka zmienił układ wierszy Jakubowskiego w następujący sposób:

1. Sonety:
a) Kamieniec
b) Tutacz
c) Piramidy
d) Do Celiny
e) Ona
f) Aut Brutus aut nihil
g) Alopeus
h) Gwiazdka i ja
i) Jesień (z Lamartinéa)
j) Przeszłość
k) Wspomnienie i nadzieja

2. Triolety

3. Dumka Gminna

4. Dumka Ukrainska

5. Do J. B.

6. Do...

7. Ideaty

8. Pożeganie. Improwizacja
9. Piosnka Tatarów (z poematu...)

10. Czarniecki w Monasterzyskach

11. Bunty Chmilnickiego. Epizod z poematu

12. Dwie gwiazdki

13. Dzwon wieczorny

14. Rozpacz

15. Uniesienie

16. Dumka Podolanina

17. Pożegnanie

18. Burza

19. Fantazja

20. Tulacz

21. Bonaparte

22. Dumanie I

23. Podole

24. Przeszłość

25. Nad morzem

26. Tęsknota

${ }^{11(x)}$ Por. A. A. Jakubow'ski, Pisma pośmiertne, red. M. Rosi enkie wi c z, Paryż 1839.

111 A. A. Jakubow'ski, Poezje, s. 4. 


\section{Przemiana}

28. Dumanie II

29. Dumanie III
30. Dumanie IV

31. Indianin

32. Indianka ${ }^{102}$

Można zauważyć, że Julian Maślanka wyodrębnił w pierwszej kolejności Sonety i Triolety pochodzące najprawdopodobniej z najwcześniejszego okresu twórczości Augusta Antoniego. Jedynie wiersze Indianin oraz Indianka, napisane pod wpływem inspiracji folklorem amerykańskim, profesor umieścił na końcu tomiku, tak samo jak Rosienkiewicz.

Jakubowski w The Remembrances... przyznawał, że chciał ukazać historię, ale stworzył jedynie fragmenty, gdyż nie był w stanie opisać zbyt bolesnych wspomnień z przeszłości. Wydaje się jednak, że właśnie to traumatyczne doświadczenie znalazło wyraz w poetyckim dorobku syna Malczewskiego. Bo właśnie w liryce od najmłodszych lat wyrażał swoje uczucia, niepokoje i marzenia, przeniknięte pesymizmem i przeczuciem nieuchronnej śmierci. Zawarł w niej historię swojego życia, stanowiącą, jak pisała Alina Witkowska, „pamiętnik duszy” młodego wygnańca. Moim zdaniem można wyróżnić kilka etapów twórczości Jakubowskiego, mającej dynamiczny przebieg i charakter silnie autobiograficzny:

1. Pierwsze próby poetyckie ucznia Liceum Krzemienieckiego do momentu aresztowania w roku 1833.

2. Utwory pisane w więzieniach we Lwowie, Brnie i Trieście.

3. Wiersze powstałe w czasie 128-dniowej podróży morskiej fregatami „Hebe” i „Guerriera” do Nowego Jorku.

4. Amerykański etap twórczości przypadający na lata 1834-1837.

Od najwcześniejszych utworów Jakubowskiego pesymizm stał się ich głównym wyznacznikiem.

Alina Witkowska podkreślała, że młody wygnaniec „ukształtował się tak, jakby go wykarmiono nie mlekiem, lecz osławionym pesymizmem $\mathrm{Marii}^{103}$, natomiast Jarosław Ławski uważa, że poezje Augusta Antoniego są jeszcze bardziej „przesycone pesymizmem niż poemat jego ojca”104. Również Jarosław Iwaszkiewicz postulował, aby nie lekceważyć tych wierszy, wskazując także na ich „pesymistyczny dramatyzm". Jak zaznaczał profesor Maślanka, Jakubowski obok swojego ojca oraz Seweryna Goszczyńskiego wpisuje się w nurt czarnego romantyzmu, a także jawi się jako prekursor tzw. „liryki ciemnej”, która na dobre rozwinęła się dopiero w Młodej Polsce.

Jego poezje to przejmujący głos pokolenia „straconego”, którego młodość przypadła na klęskę powstania listopadowego i represje z nim związane. Alina Witkowska zaznaczała, że nawet „pokolenie Cyganerii warszawskiej (...) nie osiągnęło takiego natężenia pesymizmu i poczucia obrzydliwości życia, jakie

10 J. Ławski, Malczewski - iluminacje i klęski melancholijnego wędrowca, [w:] A. Malczewski, Maria. Powieść..., s. 116. 
przepełnia wiersze Jakubowskiego"105. Badaczka podkreślała również, że ich bunt miał charakter bardziej historyczny i tyrtejski, podczas gdy u syna Malczewskiego jeżeli już się pojawiał, to w nihilistycznym ujęciu. August Antoni nazwany został przez Juliana Maślankę nie tylko "poetą tragicznym i poetą rozpaczy"106, ale zyskał też miano pisarza konstruktywisty ${ }^{107}$. Jarosław Ławski w swoich badaniach określił Jakubowskiego jako poetę kunsztownego ${ }^{108}$. Niewielka objętościowo twórczość liryczna młodego wygnańca jest bowiem niezwykle bogata zarówno pod względem tematycznym, jak i formalnym. Obfituje w sonety, triolety, poematy, improwizacje, dumy, dumki, a także utwory stylizowane na pieśni ludowe.

W czasie 21-letniego życia syn Malczewskiego osiągnął wyjątkową dojrzałość artystyczną. Warto zauważyć, że gdyby Juliusz Słowacki wziął udział w powstaniu listopadowym i zginął $w$ wieku Jakubowskiego, pozostawiłby po sobie jedynie drobne wiersze oraz dramaty: Mindowe i Maria Stuart, a także pięć powieści poetyckich inspirowanych poematami Byrona. Jeżeli umarłby w wieku Krzysztofa Kamila Baczyńskiego (czyli 23 lat), to należałoby jeszcze dodać Lambra i kilka drobnych utworów. Jakubowski był w chwili śmierci młodszy od obu poetów i nie ulega wątpliwości, że jego przedwczesne odejście stanowi niepowetowaną stratę dla naszej literatury. Kazimierz Wyka pisał, że mimo tak krótkiego życia Baczyńskiego jego twórczość jest domknięta i pełna - nie pozostawia wrażenia, że poecie przerwano w połowie artystycznej drogi. Te słowa można powtórzyć także o Auguście Antonim, biorąc pod uwagę jego dorobek poetycki.

\section{2. „U mnie nie róża - u mnie kolor czarny”, czyli o pierwszych próbach poetyckich Jakubowskiego}

Najwcześniejszy etap twórczości Jakubowskiego sprawia najwięcej problemów, gdyż poeta rozpoczął datowanie swoich utworów dopiero po aresztowaniu. Dlatego tylko niektóre wiersze można z dużym prawdopodobieństwem zaklasyfikować jako pierwsze próby poetyckie, tworzone jeszcze na Podolu. Wydaje się, że należy do nich cykl trioletów, gdyż początkujący poeta i zarazem uczeń Liceum Krzemienieckiego sięgając po te konwencjonalne, a jednocześnie kunsztowne formy, mógł tak jak inni „koledzy po piórze” doskonalić i szlifować swój warsztat. Triolety stanowiły od czasów Józefa Dionizego Minasowicza popularny gatunek, na którym swój talent ćwiczyli później między innymi Adam Mickiewicz, Edward Antoni Odyniec czy Tomasz Zan, o czym pisał Julian Maślanka. Utwory syna Malczewskiego świadczą o jego poszukiwaniach formalnych i kreatywności, gdyż

10: A. Witkowska,op. cit., s. 261.

$11 \%$ J. M a śla n ka, Poeta tragiczny - August Antoni Jakubowski (syn Antoniego Malczewskiego), [w:] i d e m, Z dziejów literatury i kultury, Kraków 2001, s. 120.

11:- Por. A. A. Jakubowski, Poezje, s. XXXVII.

${ }_{10 k}$ J. Ławski, Tragiczna i utracona - Ukraina w liryce Augusta Antoniego Jakubowskiego, [w:] Szkola ukraińska w romantyzmie polskim, red. S. Makowski, U. Makowska, M. Ne st e r u k, Warszawa 2012, s. 211. 
tylko dwa z nich wpisują się w standardowy ośmiowersowy układ wersyfikacyjny, natomiast pozostałe dwa zostały twórczo przetworzone. Również temat nie przypomina wesołych wprawek filomatów, ale jak na młodego poetę jest niezwykle poważny i już przeniknięty charakterystyczną dla całej twórczości Jakubowskiego melancholią. Triolety ukazują okresy życia róży, symbolizujące etapy nieszczęśliwej i tragicznej miłości: jej narodziny, rozkwit oraz zwiędnięcie. Warto zauważyć, że August Antoni nawiązał tym samym do tradycji liryki epicedialnej francuskiej Plejady, która uczyniła właśnie ten kwiat swoim naczelnym motywem. Wiązało się to z przekonaniem, że życie róży trwa bardzo krótko - tylko jeden dzień i stanowi odzwierciedlenie ludzkiej egzystencji. Róża symbolizowała drogocenny i kruchy skarb, jaki pomimo starań i troskliwości szybko usycha, pozostawiając same ciernie. Identyczne obrazowanie znajduje się w Trioletach Jakubowskiego. Kilkakrotnie poeta określał kwiat „wypieszczonym, wymarzonym”, zaznaczając, że mimo usilnych zabiegów zwiędnął, zostawiając tylko ciernie i „szkielet róży”109.

Dopełnieniem renesansowego ciągu motywów obecnych w liryku Augusta Antoniego jest pragnienie bohatera, aby na jego grobie złożono ukochaną różę z cierniami. By upamiętnić zmarłych, kładziono na mogiłach właśnie ten kwiat jako symbol nietrwałości życia, przemijania, a także odchodzenia ukochanych osób. Podczas gdy francuski renesans kojarzył życie róży z ludzką egzystencją, Jakubowski oryginalnie zestawił je z życiem uczucia. Nawiązał przy tym do pieśni Masek z poematu swojego ojca, pisząc o roju robaków, przed którym ochraniał swój kwiat.

W utworze tym pojawia się dodatkowo znany z literatury religijnej oraz XVI- i XVII-wiecznej emblematyki motyw pielgrzyma. Jest to wyjątkowa figura w poezjach Jakubowskiego, gdyż poeta wprowadza zwykle w swoich wierszach postać tułacza albo wygnańca. Pielgrzym w literaturze renesansowej i barokowej (na przykład w twórczości Aleksandra Teodora Lackiego oraz Zbigniewa Morsztyna) to symbol wiążący się z cierpieniem, wędrowiec nigdzie nie jest u siebie, gdyż zmierza do „ojczyzny niebiańskiej”. W życiu doczesnym nie może on zaznać spokoju, świat jest dla niego wrogi i nieprzyjazny, a wytchnienie odnajduje dopiero po śmierci. Taki obraz wyłania się również z Trioletów Jakubowskiego, gdzie główny nacisk położony zostaje na zaakcentowanie udręczenia pielgrzyma. Choć jest on „w pół życia podróży”, „wszystko [mu] zgon wróży”, „ostre ciernie serce kolą", „dawne rany bolą"110.

Natomiast cykl sonetów nosi ślady inspiracji twórczością Mickiewicza, którą Jakubowski dobrze znał, o czym świadczą The Remembrances of a Polish Exile. Trudno jednak przyporządkować cały cykl do jednego etapu jego spuścizny, gdyż składa się on z jedenastu utworów, w tym dwóch pisanych w czasie aresztowania - Alopeus i Aut Brutus aut nihil. Co ciekawe, cykl zawiera również wiersz Ka- 
mieniec, którego angielską wersję zamieścił Jakubowski w The Remembrances... Nie wiadomo zatem, czy liryk ten został napisany jeszcze $w$ kraju, a potem autor dokonał tłumaczenia, czy też powstał dopiero na emigracji.

O wczesnej predylekcji do motywów wanitatywnych oraz delectatio morosa świadczy zamieszczona w cyklu poetycka przeróbka Jesieni Lamartine'a, którą Julian Maślanka nazwał bardzo udaną ${ }^{111}$. Jakubowski stworzył sonet, ograniczając ośmiozwrotkowy oryginał do czterech strof, wysuwając na plan pierwszy paralelny obraz jesieni, przemijania i bliskości śmierci. Jego tłumaczenie jest nasycone spokojną, refleksyjną melancholią, a nie rozpaczą nieuniknionego kresu. Co ciekawe, „ja" liryczne nie tylko akceptuje naturalny stan rzeczy odbity w naturze, ale upaja się nim, sprawia mu on przyjemność:

Jak ja lubię resztkę wdzięków więdniejących!

Leja one do duszy tęskność $i$ dumanie

Jak lubego lub lubej wieczne pożegnanie

Albo ostatni uśmiech ust umierajacych ${ }^{112}$.

Jesienna pora przemijania pojawia się także w późniejszych utworach, takich jak Dumka Podolanina, ale najbardziej przejmująco powraca w Dumaniu I. Jakubowski porównał w nim siebie do usychającego drzewa, toczonego chorobą, tracącego siły wraz ze spadającymi, zwiędłymi liśćmi i przeczuwającego zbliżającą się śmierć. Pień został zainfekowany przez robactwo, którego symboliczny sens August Antoni wyłożył w Dumaniu II. Pisał, że gnieździ się „zabójczy robak w (...) wspomnieniu"113, a przeszłe chwile niczym Erynie gonią go "na kształt gromu"114 i jak "gady się wleką". Być może powracający znowu motyw z refrenu Masek: „Robak się lęgnie i w bujnym kwiecie” nie był jedyną inspiracją tego fragmentu, gdyż bardzo podobne stwierdzenie pojawiło się w Dumie o Glińskim Juliana Ursyna Niemcewicza: „Robak zgryzoty toczy me sumienie”115.

We wczesnych utworach Jakubowskiego widać patriotyczną fascynację, którą przepojona jest cała późniejsza twórczość młodego wygnańca. Najpełniej wyraża się ona w wierszu Do..., pisanym zapewne pod wpływem powstania listopadowego. Przypomina on poezję legionową - główny bohater personifikuje w nim ojczyznę jako jedyną ukochaną, dla której porzuca ziemską kochankę. Do głosu jeszcze raz dochodzi posępna melancholia i charakterystyczna dla romantyków kreacja wzniosłości tragicznych wyborów. Podmiot liryczny jawi się jako jednostka poświęcająca swoje osobiste szczęście, wyrzekająca się piękna życia i wszystkich jego powabów. Świadczą o tym słowa wiersza, w jakich jeszcze raz powraca motyw róży: „U mnie nie róża - u mnie kolor czarny”"16. W życiu prywatnym

111 Ibidem, s. XXXI.

112 Ibidem, s. 11.

11.3 Ibidem, s. 58.

114 Ibidem, s. 59.

115 J. U. Ni e m ce wi c z, Duma o kniaziu Michale Glińskim, [on-line] http://www.pbi.edu.pl/ book_reader.php?p=12318\&s=1, s. 1 .

116 A. A. Jakubowski, Poezje, s. 21. 
Jakubowskiego ta ofiara wiązała się także z opuszczeniem ukochanej matki, której nigdy miał już nie spotkać; jak pisał Rosienkiewicz: „Smutne było rozstanie się Jakubowskiego z matką, lecz dla ojczyzny żadna ofiara nie była mu za wielką"117. Mimo cierpień miłość do Polski stała się w wierszu Do... przeżyciem mistycznym, przenoszącym w sferę sacrum, sprowadzającym niebo na ziemię. Jednak tak jak każdy wzlot w utworach Jaubowskiego wiązał się nierozerwalnie $\mathrm{z}$ upadkiem, tak młody poeta miał wkrótce doświadczyć brutalnych konsekwencji swojego patriotyzmu - aresztowania i wygnania.

\section{3. „Serca mego uczta się skończyła” - utwory więzienne syna Malczewskiego}

Poezje Jakubowskiego stanowią świadectwo jego nadwrażliwości i skrajnych emocji, jakie nim targały. Ojczyznę kochał miłością ogromną, natomiast wrogów nienawidził szatańsko, co widać najwyraźniej w dwóch utworach z cyklu sonetów. W jednym z nich o znamiennym tytule Aut Brutus aut nihil [Albo Brutus, albo nic] można przeczytać:

Kto wroga krew pije,

Choćby to krew brata, syna,

$Z$ mężnym sercem Rzymianina

Polski Brutus niechaj żyje!

Trzeba urwać łeb poczwary,

Wszystkie męki, wszystkie kary,

Kto mir ma z podtościa, z musem

O tyraństwa marzą grobie

Z złościa czarta rzektem sobie:

Zginę, lecz zginę Brutusem ${ }^{118}$.

To jeden $\mathrm{z}$ niewielu utworów o charakterze tyrtejskim, w którym Jakubowski tak zdecydowanie przejawia ducha walki. Jednak w jego tle ujawnia się niepokojący nihilizm. Kontynuacją motywu ukarania zdrajców staje się kolejny sonet Alopeus (z dopiskiem Lwów, 3 maja 1833). Bez wątpienia, na co wskazuje również data, utwór ten został napisany pod wpływem zaostrzenia polityki Austrii wobec powstańców i więźniów politycznych po partyzantce Zaliwskiego. Jakubowski osobiście doświadczył tych represji, dlatego również $w$ The Remembrances... dawał upust swojej pogardzie dla austriackiego zaborcy, uważając jego prześladowania za najgorsze ze wszystkich okupantów. We wspomnianym sonecie piętnował sojusz „nikczemnego Wiednia orła (...) z carskim ptakiem"119, gdyż to właśnie pod na-

\footnotetext{
117 Ibidem, s. 67.

118 Ibidem, s. 8.

119 Ibidem, s. 9.
} 
ciskiem Rosji Austria zwiększyła rygor wobec Polaków, coraz częściej urządzając łapanki i egzekucje. W utworze tym pobrzmiewają również inne motywy obecne we Wspomnieniach polskiego wygnańca. $\mathrm{Z}$ tytułowym zdrajcą zostaje zestawiony "nowy wysłaniec tyrana Północy". Bardzo podobnie pisał w Ameryce Jakubowski o Nowosilcowie, nazywając go „narzędziem w rękach mrocznego tyrana Północy". Poczynania cara w zakresie oświaty również ostro krytykował w swoim eseju Historical Sketch of Education in Poland [Historyczny szkic o edukacji w Polsce], co uczynił także we wspomnianym sonecie ${ }^{120}$. Poza awersją do "ciemiężycieli" ukochanej ojczyzny uwypukla się w wierszu zapowiedź zemsty: „leć na krwawe boje, ale cię w drodze piorun mej zemsty uderzy"121. Eskalacja mściwości wyraża się najpełniej w wierszu Rozpacz, przypominającym emocjonalnością i siłą wyrazu Ucztę zemsty Seweryna Goszczyńskiego. Podmiot liryczny w poemacie autora Zamku kaniowskiego nawołuje "sieroty swobody" ${ }^{122}$ do piekielnej i krwawej walki w imię wolności, do zagłady starego świata. Bohaterowie utworu Jakubowskiego, nazwani „potępionymi dziećmi piekła”, dla tych samych ideałów też chcą „zniszczyć świat do dna", a „ich dłonie pragną krwi”. Jednak w poemacie Goszczyńskiego po obaleniu dawnego porządku rodzi się nowy ład, a uczestnicy biesiady zemsty kruszą swoje sztylety. Natomiast u syna Malczewskiego nie ma żadnej nadziei na zwycięstwo ani wiary w jakikolwiek porządek transcendentny. Zrzeszający się ludzie nie mają nic do stracenia, ich sprzeciw jest ostatnim akordem tytułowej rozpaczy doprowadzonej do ostateczności:

Dawno zwiędty serca nasze

I ostatnie wyschty tzy (...)

Walczyć, zniszczyć - cała rzecz,

W kim nadzieja nie uciekta -

Precz przed nami, precz!n

Początkową chęć buntu wkrótce zastąpiło poczucie kompletnej niemocy i bezsilności. Przedłużająca się samotność i rozwianie nadziei na pomoc wygnańcom ze strony Francji tylko pogłębiły jego depresję. Kolejne utwory pisane chronologicznie to: Pożegnanie. Improwizacja (Lwów, 10 czerwca 1833), Dzwon wieczorny (Triest, 24 października 1833) oraz Dumka Podolanina (8 listopada 1833). Uwięzienie młodzieńca sprawiło, że jego wrodzona skłonność do refleksyjnej melancholii nasiliła się, zamieniła $w$ rozpacz, obsesję śmierci i zadziwiająco szybko w jej bierne oczekiwanie, co podkreślał prof. Ławski. Już w pierwszym wspomnianym

121) Ciemięża - skutek czego? - zapewne oświaty;

Oto jej nowy rodzaj, to jej próbka nowa,

Rosja to tę skarbnicę nauk w sobie chowa;

Wielkie szkoly! Ach, jakież z niej szpiegi i katy.

121 Ibidem.

A. A. Jakubowski, Poezje, s. 9.

122 J. Tu w i m, Ksiegga wierszy polskich, t. 1, Warszawa 1956, s. 167.

${ }^{12.3}$ A. A. Jakubowski, Poezje, s. 35. 
utworze Jakubowski trzykrotnie powtarzał, że jego „serca uczta się skończyła”"124. Podkreślał, że z chwilą utraty wolności zabito wszystkie jego uczucia i marzenia, a tym samym szczęśliwe życie bezpowrotnie odeszło w przeszłość. W jego słowach nie ma jednak buntu, ale jest cicha rezygnacja. Zupełny brak chęci do walki pojawia się również $w$ innych utworach, widać $w$ nich przekonanie o ciążącym nad poetą fatum, którego nic nie może zmienić:

tza nie zmienisz woli nieba

Śmierć i życie w ręku Boga ${ }^{125}$.

Również w chwili pożegnania podmiot liryczny wydaje się wypalony uczuciowo, nie targają nim wielkie namiętności, kiedy żegna się z przyjaciółmi. Rezygnuje z układania „pożegnań piosnki”, sam dziwi się, że nie roni łez. Autor niezwykle sugestywnie ukazał dramat egzystencjalny młodego i utalentowanego poety, przyrównanego do orła lecącego w okowach. W utworach Jakubowskiego często pojawia się fatum, które każdy wzlot marzeń bezlitośnie ściąga w dół: „Kto leci śmiałym uniesion zapałem,/ Wnet go tam kula zabija"126. W Dumaniu I natomiast „myśl, co miała lecieć w górne światy,/ skrępowana lańcuchy umiera za mlodu"127.

W Dzwonie wieczornym powraca przeczucie śmierci najbliższych poecie osób (stały motyw Marii) - matki i bliżej nieokreślonej ukochanej ${ }^{128}$. Również paralelnie do poematu ojca pojawia się „robak straty”. Podobne uczucia występują także w innym wierszu poety pt. Tęsknota. Z kolei w Dumce Podolanina pierwszy raz Jakubowski mówi o sobie jako o wygnańcu, chociaż znajduje się jeszcze w więzieniu. Przebywając ponad trzy miesiące w zamknięciu, zaczynał już projektować swoje tułacze życie, ale przede wszystkim ciągle prześladowała go wizja własnej śmierci. Patrząc na horyzont morza, mówił: „Tam grób mój”. Co ciekawe, fakt ten nie wywoływał w nim smutku, ale - podobnie jak w Pożegnaniu - radość, gdyż zgon jawił mu się jako upragniony koniec cierpień. $\mathrm{Z}$ goryczą pisał o losie polskich patriotów, jaki stał się jego udziałem:

Bo taka dzisiaj nagroda

Dla naszych poświęceń, ran,

Za ojczyznę nasza - woda,

A wicher-tułaczów pan ${ }^{129}$.

12.4 Ibidem, s. 25.

125 Ibidem, s. 31.

126 Ibidem, s. 28.

12: Ibidem, s. 49.

12. Ze względu na autobiograficzny wymiar tekstu można podejrzewać, że Jakubowski przebywając w zamknięciu, nie mial kontaktu z bliskimi, z którymi nie zobaczyl się nawet przed opuszczeniem kraju na zawsze, o czym wspomina wiersz pt. Pożegnanie, datowany na 2 grudnia 1833 roku.

${ }^{129}$ Ibidem, s. 39. 


\section{4. „To morze będzie moim grobem i siedliskiem” - utwory akwatyczne Jakubowskiego}

Bardzo często $w$ twórczości poetyckiej Jakubowskiego pojawia się motyw wody, który w Marii posiada szczególnie symboliczne, złowrogie znaczenie. Gaston Bachelard w swojej pracy Woda jako żywiot wyobraźni. Psychoanaliza obrazów wody pisał, że morska dal dopełnia symbolizmu śmierci, która jawi się jako ciężka i powolna męczarnia bez perspektywy zmartwychwstania. W utworach marynistycznych syna Malczewskiego uwidacznia się kompleks Charona jako ciągłego zdążania, żeglowania do kresu życia. Nastrój skrajnego pesymizmu wypełnia jego poezje pisane na fregacie „Hebe”, którą przez 128 dni płynął do Nowego Jorku. Stanowią one przejmujące świadectwo stanu ducha poety coraz bardziej oddalającego się od domu. We wcześniejszych utworach Jakubowski wyznawał, że $w$ trudnych chwilach ukojenie przynosiły mu radosne wspomnienia przeszłości, nadzieja oraz ucieczka w krainę wyobraźni ${ }^{130}$. W kolejnych lirykach obsesyjnie i jak refren powraca woda jako symbol śmierci, aqua abyssi. Myśl o niej prześladuje go, osacza niczym wszechobecny ocean statek, którym płynie:

Zawsze za mna i przede mna

Tylko morze, morze, morze ${ }^{131}$.

Również w Pożegnaniu Jakubowski pisał:

Grób mój będzie wielki jak ocean caty

Wielkość i nicość - czysty obraz zgonu ${ }^{132}$

oraz w Dumaniu I: „To morze będzie moim grobem i siedliskiem”. Także w utworze Nad morzem poeta ukazał "falę czarną jak u trumny wieko"133.

Motyw ten ma jednak jeszcze inne realizacje $w$ dorobku poetyckim Jakubowskiego. Woda została ukazana nie tylko w swojej niszczycielskiej sile, unosząca marzenia i nadzieje, a nawet obrazy ukochanych osób. Jawi się również jako jedyny towarzysz i świadek cierpienia młodego wygnańca, który sprawi mu pogrzeb i zapłacze nad jego odejściem. Morze jako nieprzenikniona tafla symbolizuje zagadkę bytu, nie dopuszcza do głębi swoich tajemnic niczym w pierwszym sonecie cyklu Nad głębiami Adama Asnyka. To sprawia, że „ja” liryczne cały czas zmuszone jest widzieć własne odbicie i więzi je w ciągłych iluminacjach jaźni niemogącej wyjść poza samą siebie. W wierszu Tułacz Jakubowski przedstawił intrygujący obraz żeglującego wygnańca, którego twarz wygląda jak maska, zmieniająca się w zależności od sytuacji. Przypomina on Pieśń wulkanu Goszczyńskiego, gdzie upersonifikowany tytułowy bohater przekonuje, że dawno wygasł, podczas gdy

1:4) Por. wiersz Wspomnienie i nadzieja.

131 A. A. Jakubowski, Poezje, s. 44.

132 Ibidem, s. 41.

133 Ibidem. 
po cichu obmyśla zagładę wrogów. Podobnie Jakubowski sugerował, że tułacz przypominający upiora nie jest tym, kim mógłby się wydawać:

Czy on tam dawne popioty pamiatek,

Czyli ukryte wulkany tam chowa? (...)

Czucie to skryte jeszcze nie wylata,

Lecz gdy z rozdartej piersi się dobędzie,

Jak traba sądu będzie głosić wszędzie

Zgon starych królów, zgon starego świata ${ }^{134}$.

Wiersz ten należy do nielicznych wyjątków w twórczości poetyckiej wygnańca, gdyż dominujący w niej nastrój to rezygnacja, a także oczekiwanie na nieuchronną katastrofę, tu zaś mowa jest o zakamuflowanym przez zaborcę pragnieniu zemsty i buncie. Kiedy w wierszu Piramidy Jakubowski rozpaczał, że nie może tak jak one obojętnie patrzeć na zagładę swojego narodu, w Pożegnaniu, będąc już na statku, pisal, że jego „łono jest zimne jako łono fali” ${ }^{135}$. Liryk ten ma też znaczenie symboliczne i przypomina pożegnanie $\mathrm{z}$ życiem. Jak pisał Julian Maślanka - dwa wersy: „Jednak nade mną niech się nikt nie żali/ Niechaj nade mną nikt nie ubolewa” - przypominają słowa znanego utworu Wyspiańskiego: „Niech nikt nad grobem mi nie płacze"136.

\section{Novum w polskiej poezji - Indianin i Indianka}

W twórczości Jakubowskiego pojawiają się także utwory inspirowane Ameryką, jednak nie nową cywilizacją, ale jej rdzennymi mieszkańcami. Chociaż przed synem Malczewskiego wielu polskich literatów odwiedzało Nowy Świat, żaden $\mathrm{z}$ nich nie pozostawił po sobie utworów bogatych $\mathrm{w}$ indiańskie realia folklorystyczne. Wśród nich były tak słynne osobistości, jak: Maurycy Beniowski, Tomasz Kajetan Węgierski czy Julian Ursyn Niemcewicz. Wiersze syna Malczewskiego są niezwykle oryginalne nie tylko na tle twórczości autora, ale całej ówczesnej literatury polskiej. Świadczą one o dobrej znajomości zwyczajów i wierzeń Indian, jak również o sympatii dla nich. Julian Maślanka podejrzewał, że August Antoni mógł osobiście zwiedzić tereny pogranicza amerykańsko-kanadyjskiego i zetknąć się z Indianami, np. Huronami. Zamieszkiwali oni okolice Wielkich Jezior położonych niedaleko Albany - miasta, do którego przybył młody poeta razem z 25 innymi wygnańcami. Indianie stanowili tam niewielką grupę. W wyniku rzezi tego plemienia dokonanej przez Irokezów zostali oni zdziesiątkowani. To właśnie wodza Huronów Segamora uczynił Jakubowski głównym bohaterem Indianina. Nie wydaje się jednak, by - jak pisał wydawca Poezji - polski wygnaniec miał na myśli konkretną osobę, gdyż termin „segamore”, podobnie jak „sachem”, oznaczał pierwotnie tytuł najwyższego zwierzchnika wspólnoty indiańskiej.

134 Ibidem, s. 45.

1.5.5 Ibidem.

136 J. Ma śla nka, Poeta tragiczny..., s. 114. 
August Antoni podzielił swój liryk na dwie części. Pierwsza, pisana ośmiozgłoskowcem, stanowi wypowiedź wodza, świadomego zagłady swojego plemienia i przeczuwającego własną śmierć. Utwór wypełniony jest słownictwem nawiązującym do kultury czerwonoskórych, takim jak: Manitto, chingahawk, segamor, a także pokazującym przynależność plemienną oraz miejscową: „Hurania dąb jedyny”, „Hurański las”, „woda słonego jeziora” (nawiązanie do Wielkich Jezior), „rzeka Missispi”, „Zberon”. Druga część wiersza, utrzymana w formie jedenastozgłoskowca w elegijnym tonie, ukazuje obraz po eksterminacji Indian, kiedy ich ojczyzną rządzą obcy, a rodzinna ziemia nie chce przyjąć ich kości. Utwór ma charakter antykolonialny. Jakubowski okazuje w nim nie tylko szacunek, ale również zrozumienie i współczucie dla pierwotnych mieszkańców Ameryki. Przyczyny tej empatii zostały wyjaśnione w The Remembrances..., na co nie zwracano do tej pory uwagi przy analizie tego utworu. Jakubowski widział bowiem agonię Indian jako paralelny los Polski. Pisał: „Nawet w chwili naszej śmierci politycznej umieraliśmy jak Indianie i torturowani śpiewaliśmy pieśń śmierci"137.

Ameryka jawiła się poecie nie tylko jako miejsce wygnania, eskalacji obcości i samotności, ale również jako ziemia niewolnictwa i przemocy. August Antoni musiał wniknąć w kulturę plemienną, o czym świadczy wprowadzenie do utworu największego bóstwa Indian północnoamerykańskich - Manitto, który stworzył ziemię, a później zamieszkał $w$ niebiosach. W wierszu pojawiają się także elementy charakterystyczne dla wiary totemicznej o przenikaniu się świata transcendentnego i materialnego. Zgodnie $\mathrm{z}$ tymi wierzeniami duchy zmarłych przebywały w różnych elementach przyrody, dlatego też poeta jako miejsce wiecznego pobytu wodza po śmierci wyznaczył jezioro. Warto również zwrócić uwagę na dobór najczęściej powtarzających się epitetów wykorzystywanych przez Jakubowskiego, które obecne są w takich dziełach, jak: Ostatni Mohikanin Coopera czy Pieśń o Hajawacie Longfellowa. Są nimi: „wielki” oraz „biały”. Ten ostatni, wyjątkowo posiadający pejoratywne konotacje w twórczości poety, skontrastowany został z ciemnymi barwami, towarzyszącymi Indianom. Jak zauważył Maślanka, Jakubowski pierwszy raz w literaturze polskiej użył popularnego później sformułowania „biała twarz". Kolonizatorów nazywał także „białymi psami”, którzy nie tylko zgładzili całe pokolenia Indian, ale zbezcześcili ich ziemię:

Dajże ziemio, grób dla pana,

Daj toże dla Segamora;

Lecz Ty podta, ty skalana,

Ty pod wtadza dzis topora (...)

I tylko jasne, wielkie, stone wody

Do tona swego przyjęty go skrycie;

Bez grobu leża indyjskie narody,

On ma grób wielki jako wielkie życie ${ }^{138}$. 
Jakubowski ukazał Indian nie jako niewykształconych dzikusów, ale ludzi głęboko zakorzenionych w wielowiekowej tradycji, religii i kulturze. Często w pismach europejskich podróżników, jak na przykład u Antoniego Ferdynanda Ossendowskiego w Niewolnikach słońca, biały człowiek ukazany był jako Prometeusz przynoszący światło cywilizacji pogrążonym w mroku tubylcom. Schemat ten zupełnie odwrócil August Antoni. Wydaje się, że ciemny kolor oznacza tajemnicę, wiedzę niedostępną dla Europejczyków, natomiast biel uosabia niszczycielską siłę, przypominającą powietrze rujnujące starożytne freski w Rzymie Felliniego.

W Indianinie został ukryty obraz utraconego Podola, od którego Jakubowski nie mógł się uwolnić, podobnie jak od obsesyjnej myśli o zapomnieniu po śmierci i grobie daleko od ojczystych stron. Motyw ten pojawia się w wielu utworach wygnańca:

Gdy opadnę losów sitą,

Nikt nie optacze przychodnia

[Dwie gwiazdki]

W obcej ziemi gdzieś skończę życie me tułacze,

Grób mój nie będzie między groby podolskimi,

Dusza tylko w ojczyźnie, choć proch w obcej ziemi

(...) me imie

Wkrótce tu zapomniane nikogo nie wzruszy

[Tutacz]

A ja jako krzew w obce przeniesiony strony,

Za którym ni ptak westchnie ani zdrój zaptacze,

Zwiędnę, od mego kraju, lubej zapomniany,

Pogrzebię czucia, chęci jak życie tutacze.

I chyba gdy wiatr piasku zaniesie tumany

I usypie mogitę moja w obcej ziemi,

Moze ten wiatr z ojczyzny mojej zblakany

Prochy jakiego ziomka pomiesza z moimi

[Dumanie II]

Przejmujące zakończenie wiersza Dumanie II przypomina Zofiówkę Stanisława Trembeckiego, w której autor nie wierząc w życie wieczne, uważał, że jedyne pokrzepienie dla rodziców zmarłych dzieci może wypływać z tego, iż wiatr przywieje prochy pociech, które musną ich policzki:

Co nam zostaje życzyć: niech do tej ustroni

Popioty $z$ ciatek waszych przenosza Fawoni ${ }^{139}$.

Wiersz Jakubowskiego jest wyrazem ostatecznej rozpaczy, wiary nie w opatrzność, ale w fatalność swojego losu. Brakuje nawet nadziei na to, że jego prochy trafią do ukochanej „ustroni”, czyli ojczyzny. W utworze nie pada ani jedno słowo 
o duszy, autor skupia się tylko na doczesnym wymiarze bytu. Jedyne pokrzepienie udaje mu się odnaleźć w wanitatywnej wizji zmieszania popiołów z prochami rodaków, przy czym nie wspomina nic o odrodzeniu i zmartwychwstaniu.

$\mathrm{Na}$ uwagę zasługuje również fakt, że Jakubowski nawet na krańcu świata, w Ameryce pozostał wierny swojej ojczyźnie, w której - jak pisał - duszą był cały czas. Pamięć o niej - „robak straty”, a także ciągłe poczucie bezdomności („nie mając piędzi ziemi wśród ziemskiej krainy ${ }^{140}$ ) pozwoliły mu wczuć się w sytuację Indian. Syn Malczewskiego posiadał uniwersalistyczne spojrzenie na świat, dlatego los Polaków pod zaborami jawił mu się jako paralelny również do niewoli babilońskiej. Stąd w wierszu Tułacz przyrównał siebie do usychającej „wierzby Babilonu". Poza tym piramidy, które przeżyły swoich budowniczych i zmuszone były do patrzenia na nowy porządek $w$ ich rodzinnej ziemi, także przypominały mu ojczyznę, o której wypowiadał się z czułością:

Równie i Polska znikła, kraj mój ukochany,

Gdzie miecz brzękat, tam teraz brzękaja kajdany

Lub obce ucho ziomka uderza wyrazy ${ }^{141}$.

Kolejny utwór pt. Indianka ma charakter miłosny. To dialog indiańskiej dziewczyny i białego mężczyzny. Jakubowski pokazał w nim równość między ludźmi różnych ras, którzy nie tylko mówią do siebie „bracie” i „siostro”, ale pragną swojej bliskości oraz zakochują się w sobie. Wiersz w przeciwieństwie do Indianina ma pogodny charakter i pokazuje, że przyjaźń oraz braterstwo między ludźmi o innym kolorze skóry są możliwe. W liryku również dominuje biały kolor, a całość opiera się na koncepcie powtórzeń $w$ formie pytania i odpowiedzi:

$O$, bracie, $z$ dalekiej krainy,

Ty jesteś jako śnieg biaty.

Czy biate córy doliny,

Lilie twoje siostrzyce

Wiecznie ciebie catowaty,

Że tak zbielaty twe lice?

Skad w takich ogniach twoje źrenice?

Powiedz, czy ty bytes $w$ niebie

I skradtes tam blyskawice?

Czyli sokoty, twoi bratanie,

Przylatywaty do ciebie

I ty przez moźne czary

Wykradteś im z oczu żary?

On:

Siostro, chcesz być jak ja biała?

Rób, jak lilie me siostrzyce: 
Catuj, catuj moje lice,

A będziesz jako śnieg biała

I jak lilie me siostrzyce.

Chcesz mieć w oczach błyskawice?

Wiecznie patrz się w moje oczy,

A pertowy blask $w$ nie wskoczy

I będa jak btyskawice... ${ }^{142}$.

\section{6. „Gdzież jest miła moja dola, kiedym dumał wśród Podola?” - poezja nostalgii}

Rosienkiewicz pisał o poezjach Jakubowskiego, że: „Wolność, ojczyzna i matka całe jego serce i myśli zajmowały i nimi tchną wszystkie jego pisma"143. Podole w twórczości Jakubowskiego pojawia się nie tylko jako utracone locus amenous, ale również w swoich historycznych odsłonach. Wśród nich występuje Piosnka Tatarów, którzy w XIX wieku byli już reliktem historii. W pewnym sensie stanowi ona rozwinięcie wątku Marii, ponieważ Wojewoda i Wacław odpierali atak właśnie Tatarów. Sytuacja liryczna utworu przedstawia natomiast oddział wybierający się „na łowy (...) na pogana Polaka", charakteryzujący się prymitywną radością ludzi z natury żądnych krwi. Natomiast inny wiersz Czarniecki na Monasterzyskach przedstawia drugą stronę konfliktu w czasie ekspedycji odwetowej przeciwko Kozakom. Jak zauważył prof. Ławski, utwór ten, utrzymany w konwencji ballady, stanowi ciekawy przykład tytanicznej kreacji herosa i jego dekonstrukcji w topice wanitatywnej i mortualnej. Jakubowski przyrównał Czarnieckiego do archanioła, a później przedstawił go jako wodza, który poległ na polu chwały. Natomiast po jego cudownym ozdrowieniu zupełnie zmienił tonację utworu, uderzając $w$ akord makabryzmu:

Dzisiaj w ich czaszkach gady $i$ węże,

Ich ciata kryja mogity ${ }^{1+4}$.

Ukraina w twórczości Jakubowskiego jawi się jako ziemia różnych nacji - Kozaków, Tatarów i Polaków - kochających przede wszystkim wolność. Dlatego też w zachowanym epizodzie z Buntów Chmielnickiego hasło Zaporożców brzmi: „Wolnym się rodzić, wolniejszym umierać"145, a cały fragment wypełnia przekonanie, że nikt nie jest w stanie stłamsić ducha swobody. Tak jak w The Remembrances of a Polish Exile Jakubowski wyrażał fascynację mentalnością i losem Kozaków, starał się być także obiektywny, opisując ich relacje z Polakami. Zarówno Julian Maślanka, jak i Jarosław Ławski są zgodni, że gdyby poemat został ukończony, mógłby być jednym $z$ oryginalniejszych w naszej literaturze.

1.12 Ibidem, s. 64.

1.3. M. Rosie nkie wi c z, Wiadomość biograficzna..., s. 68.

in A. A. Jakubowski, Poezje, s. 29.

145 Ibidem, s. 30. 
Wydaje się, że największy wpływ na twórczość Augusta Antoniego, poza wspominanymi przez przyjaciela Mickiewiczem i Malczewskim, miał Maurycy Gosławski, nazywany „bardem Podola”. Jakubowski świadomie wybrał ten właśnie wariant szkoły ukraińskiej. W obrazowaniu i stosowanej przez niego topice widać sporo podobieństw do twórczości autora Gdyby ortem być!, z którym łączyło go wiele wspólnych doświadczeń biograficznych. Urodzeni $w$ tym samym regionie przedstawiali Podole jako na zawsze utraconą Arkadię. W okresie aresztowania tak samo tęsknili do spojrzenia lubej i "słowika podolskiej błoni"146, wnikających do miejsca ich niewoli. Patriotyzm stał się głównym tematem ich wierszy, bogatych w zbliżoną metaforykę. W jednym z nich pojawia się gwiazdka nad obłokiem, która „zda się łzą" - na tym właśnie obrazie Jakubowski zbudował swój utwór Dwie gwiazdki. „Rozpaczy grom” występuje w takich lirykach Augusta Antoniego, jak: Burza, Tułacz i Alopeus. Natomiast figurę „błędnego tułacza” można odnaleźć w Przeszłości, a "męczeństwa krwawe wieńce" w turpistycznym wydaniu w Przemianie. Gosławski porównywał serce wygnańca do „cichej mogiły” oraz do urny ${ }^{147}$. Podobny motyw często powraca w liryce Jakubowskiego (np. w wierszu Tułacz czy Dumanie I). W chwilach największej depresji młody poeta przyrównywał nie tylko serce, ale również duszę do kamienia cmentarnego, na którym wyryto „szczęścia szczątki”. Gosławski pisał w podobnym tonie:

A my - tułacze, jak brzozy żałobne,

We mgle nocy, w tẹsknocie, jak glazy nagrobne

dogasamy na mogile ${ }^{\prime \prime 18}$.

Jednak jego utwory nie są $\mathrm{w}$ tak wielkim stopniu przepojone cierpieniem oraz bezsensem życia i nie noszą piętna wiecznego potępienia, a przede wszystkim obsesji śmierci.

Jakubowski obok swojego ojca staje się najbardziej posępnym piewcą Ukrainy. Z jego wierszy wyłania się portret psychologiczny ich autora, przypominający Malczewskiego, którego uwiecznił Zaleski na krótko przed tragicznym zgonem, pisząc o nim: „zwiędły, bo już go dogryzały smutki” ${ }^{149}$. Zwiędłe serce, szkielet róży, usychanie, utrata sił witalnych i upodobnienie się do upiora za życia to podstawowe wyznaczniki liryki Augusta Antoniego. W poezji cenionego przez autora The Remembrances... Bohdana Zaleskiego pojawiają się tęsknota, melancholia, żal i smutek, ale nie rozpacz. Realizuje się w niej potrzeba konsolacji, a także nadzieja i wola walki w imię odrodzenia ojczyzny, czego nie znajdziemy u Jakubowskiego. Jednak młody wygnaniec, podobnie jak wspomniani pisarze związani z Ukrainą, sięga po „rodzinny” gatunek dumki. W jego spuściźnie poetyckiej opracowanej przez Rosienkiewicza znajduje się kilka takich utworów, zrytmizowanych pieśni

146 M. Goslawski, Wybór poezji, red. J. Lys z c z yna, Katowice 2005, s. 70, Prace Naukowe Uniwersytetu Sląskiego w Katowicach, nr 2309.

14: Ibidem, s. 74.

149 Ibidem, s. 175.

149 J. Tu w im, Księga wierszy polskich, t. 1, Warszawa 1956, s. 198. 
w elegijnym tonie, zawsze związanych z tematem śmierci. W Dumce ukraińskiej Jakubowski zawarł głębszą refleksję nad duchem Ukrainy. Jarosław Ławski zauważył, że pełna uroczysk z jednej strony, jest piękna niczym ukraińska dziewczyna, "jak kwiat na stepie lekka i dzika"150. Jawi się jako ziemia Osjana, gdzie w świetle księżyca w pobliżu swoich mogił przechadzają się duchy przodków. $Z$ drugiej jednak strony Jakubowski podobnie jak w The Remembrances... przedstawił Ukrainę nie tylko jako jeden $z$ najpiękniejszych regionów Rzeczypospolitej, ale też jako obszar "ciągle spływający krwią", naznaczony fatum, piętnem ciągłych nieszczęść i tragedii. Dlatego też urodziwa dziewczyna zostaje zestawiona z „krwawym, bladym widmem"151 powstającym z kości, by opowiadać o minionych dziejach. Nie bez przyczyny wicher jako jedyny „bard w Ukrainie” szumi „pieśń stepową" właśnie na grobach, gdzie została cała świetność dawnej chwały, która odeszła bezpowrotnie tak jak szczęśliwe chwile młodego wygnańca.

Żywe zainteresowanie folklorem ukraińskim przenika wiele utworów Jakubowskiego. Jako poeta często stosował lirykę roli, co uczynił również w Dumce Podolanina, konstruując tak jak w Indiance sytuację rozmowy między kobietą a mężczyzną. Dziewięciozwrotkowy dialog wypełniają czterowersowe strofy złożone naprzemiennie z 8- i 6-zgłoskowych wersów. Pierwsza część utworu jest stylizowana na podolską pieśń żeńską. Przedstawia ukochaną, która tęskni za Kozakiem wyruszającym na wojnę. Pojawiają się w niej charakterystyczne dla ludowego obrazowania motywy: słowik oraz wierzba płacząca, zestawiona przez poetę ze stanem ducha dziewczyny. W drugiej części dumki podmiot liryczny odpowiada dziewczynie poprzez trzykrotne spiętrzenie zhiperbolizowanych obrazów uświadamiających, że jej miły nigdy nie powróci. Zwieńczeniem gradacji staje się ostatnia zwrotka:

Prędzej braknie w Dnieprze wody,

Braknie gwiazd na niebie,

Niźli się twój luby zbudzi,

Niz uściśnie ciebie ${ }^{152}$.

\section{7. „I już więcej nie pomarzę i już więcej nie polecę” - dojrzewanie do śmierci}

Jarosław Ławski pisał, że Jakubowski lubując się w śmierci, unikał turpistycznych obrazów. Jednak w Dumce Podolanina ukazał przerażający obraz łąki, na której zamiast kwiatów znajdują się kości. Na scenę wprowadził także spersonifikowaną Wojnę ${ }^{153}$, wijącą wianek z kości i czaszek. Zamiast deszczu wszystko

(:0) A. A. Jakubowski, Poezje, s. 18.

151 Ibidem.

152 Ibidem, s. 17.

$15: 3$ Podobnym zabiegiem posłużyl się Antoni Malczewski w Odzie do Wojny, jednak nie wiadomo, czy Jakubowski znał ten utwór. W powyższym fragmencie widać również echo Pieśni Osjana. 
spływa krwią, a w miejsce motyli pojawiają się duchy, unoszące się nad łąką, która stała się polem bitwy. W poezjach Jakubowskiego często występują florystyczne motywy związane z beztroskim czasem szczęścia i radości, który na zawsze przeminął. Podobny do wspomnianego utworu przejmujący obraz powraca $w$ innym wierszu o znamiennym tytule Przemiana. Posiada on charakterystyczną budowę opartą na kontraście. Pierwsze dwie strofy ukazują radosnego młodzieńca, który zbiera kwiaty na wieniec symbolizujący jego marzenia i fantazje - w nim dokonuje lotu „wysoko ponad Tatry”. Jednak obraz ten należy bezpowrotnie do przeszłości, co akcentuje wyraźnie pierwsze słowo utworu „niegdyś". Natomiast trzecia i czwarta zwrotka przedstawia tego samego bohatera „dzisiaj”, stojącego nad grobem, zbierającego kości na wieniec w przeświadczeniu, że nigdzie już nie poleci.

Gaston Bachelard podkreślał, że wyobraźnia związana z powietrzem i lotem, w przeciwieństwie do wodnej czy ognistej, tworzy szczęśliwe obrazy radości i wzniosłości. W utworach syna Malczewskiego sytuacja lotu wiąże się nierozerwalnie z upadkiem, transgresja prowadzi do gorzkiej wiedzy, że „nie będzie, co już było" 154 i pogrąża autora w jeszcze większym pesymizmie. We wspomnianym utworze widać wyraźnie, że „ja" liryczne przeszło nieodwracalną przemianę w bardzo krótkim czasie, gdyż Jakubowski przedstawiał bohatera za każdym razem jako „młodzieńca”. Chociaż August Antoni nigdy nie zdążył się fizycznie zestarzeć, jego wiersze są przepełnione gorzkim doświadczeniem starego człowieka, który chciał „śpiewać pieśń nieśmiertelności”, ale zawiódł się na wszystkim, w czym pokładał nadzieję i nie widzi już sensu życia. Bardzo przejmująco brzmi credo zamykające liryk:

\section{$Z$ czaszek ułożę ottarze,}

Trawiący ogień rozniece

I już więcej nie pomarzę,

I już więcej nie polecę ${ }^{155}$.

Można powiedzieć, że jest to wyznanie niewiary, o czym pisał Jarosław Ławski, pewnego rodzaju nihilizmu. Wydaje się, że poeta nie wierzył w osobowego Boga, ale w fatalną siłę, opisaną także w Majorze Aleksandrze, ironicznie szydzącą z ludzkich poczynań, podobnie jak w Marii Malczewskiego. Bezpośrednio wyraża to również wiersz Przeszłość, gdzie wobec „burzy cierpienia” i złudnych nadziei bohater stwierdza: „W Boga, w ludzi nie ma wiary” ${ }^{156}$. Człowiek to dla poety „jedna iskra wielkiej duszy świata". W Dumaniu IV, nazwanym przez Juliana Maślankę najbardziej przejmującym wierszem Jakubowskiego, przyrównanym przez niego do Matki Polki, pojawia się przekonanie, że po śmierci dusza nie znajdzie ukojenia w harmonii wszechświata. W rzadkich chwilach szczęścia August Anto-

1:n Ibidem, s. 20.

155 Ibidem, s. 57.

156 Ibidem, s. 53. 
ni zatapiając się w marzeniach, zasiadał "na tronie wyobrażeń" i w akcie deifikacji sam sytuował siebie w centrum świata, pisząc o sobie „Bóg przyrodzenia”157.

Kiedy we wczesnych wierszach Jakubowskiego śmierć jawi się jako alternatywa śmiałych wyborów i poświęcenia, w kolejnych staje się już pewnością, a zarazem obsesją autora. W niewielkim objętościowo tomiku, liczącym zaledwie 42 wiersze, aż w 86 procentach powraca motyw umierania w najróżniejszych odsłonach albo sama sugestia śmierci. Pełne rozpaczy wiersze syna Malczewskiego stanowią niezbity dowód pogłębiającej się depresji. Pokazują zamknięcie się na świat, utratę wszelkiej nadziei, a w końcu dojrzewanie do śmierci i jej pragnienie. W wierszu Fantazja Jakubowski wyznawał:

Stońce stoi na potudniu,

Wiatr od wschodu wieje mile,

A w mym sercu gdyby w grudniu,

A w mej duszy jak w mogile ${ }^{158}$.

Natomiast gdy opisywał krajobraz po burzy, stwierdzał:

A w mej duszy nie ma ciszy,

A w mej duszy ciagta burza,

Serce radości nie styszy,

Coraz bardziej się zachmurza ${ }^{159}$.

Powoli gasły w Jakubowskim wszystkie uczucia - nawet chęć zemsty i buntu, czuł się martwy już za życia. Dlatego też tak często w jego twórczości pojawia się „zwiędłe” serce, przyrównywane do mogiły czy urny z popiołami, kry lodu lub wygasłego wulkanu. Postać tułacza jawi się natomiast jako "grobowy upiór wśród żywego świata” ${ }^{160}$, który wprawdzie jest „na świecie, ale już nie dla świata”. Przejmująco stan ten ujął Jakubowski, pisząc o nim w trzeciej osobie z zimną precyzją i przenikliwością:

Bo jemu zaszło, co dla drugich wschodzi,

Oczy mu btyszcza jako zalu żmije,

Umarta dusza jako pomnik żyje

I chyba w przyszłym świecie się odrodzi ${ }^{161}$.

Warto podkreślić, że w swoich lirykach Jakubowski wpisuje się w estetykę symbolizmu związaną z tradycją Marii Malczewskiego. Wypływa ona z koncepcji wyalienowanej jaźni niemogącej wyjść poza samą siebie. Stąd w wierszach poety promienie świata zewnętrznego nie są w stanie przeniknąć do grobowca, a podmiot liryczny pogrążony jest w mroku i rozpaczy. Pisarz nie odczuwał ekstazy

\footnotetext{
157 Ibidem.

1:ix Ibidem, s. 44.

$1: 59$ Ibidem, s. 42.

1(x) Ibidem, s. 58.

161 Ibidem, s. 59.
} 
śmierci tak jak inny samobójca Henrich von Kleist, a swój przejmujący wiersz Dumanie IV zamknął słowami: „Smutno po zgonie, nie smutniej niż w życiu”162.

Jak zauważył Jarosław Ławski, wszystkie pejzaże wewnętrzne w poezjach Jakubowskiego są odmalowane za pomocą ciemnych barw: dominuje w nich mrok bezgwiezdnej nocy i wnętrza grobu. Jest to o tyle ważne, że gwiazda w liryce syna Malczewskiego to symbol nadziei, a także nić łącząca go $z$ dawnym światem ${ }^{163}$. Autor kreśląc obraz teraźniejszości, pokazuje zmierzch słońca szczęścia (Rozpacz), zgaszone światła uczty, podkreślając przy tym „u mnie nie róża - u mnie kolor czarny”, „dla mnie wszędzie zimno, ciemno"164. Kontrastuje to z przeszłością ukazaną zazwyczaj w jasnych, świetlistych kolorach, florystycznej metaforyce i związaną z doświadczeniem lotu, tak jak w wierszach: Fantazja, Uniesienie, Ideaty.

Jakubowskiego, podobnie jak Słowackiego, wyróżniała silna więź z matką, co również znalazło wyraz w jego twórczości. Podobnie jak w Rozłączeniu wieszcza, w szeregu utworów młodego wygnańca zaznacza się duchowa i uczuciowa bliskość między oddalonymi osobami, gdzie "jedno o drugim pamięta”. Jakubowski w swojej matce widział jedyny łącznik z na zawsze utraconym Podolem. Myśl o niej była dla niego z jednej strony konsolacją, wytchnieniem w samotności, ale $\mathrm{z}$ drugiej stawała się powodem masochistycznego rozpamiętywania:

Bywaj zdrowo, matko droga,

Drugiej matki bronić trzeba

(...)

Matka wzdycha i oczyma

Wyptakata zalu rzeki

Jedna po nim matka placze.

I plakata tak wiek caty ${ }^{165}$.

Wyznanie liryczne młodego poety koresponduje ze słowami Rosienkiewicza w Wiadomości biograficznej, gdzie przyjaciel stwierdzał, że pożegnanie z matką Jakubowskiego było bolesne, ale „żadna ofiara dla ojczyzny nie była mu zbyt wielka"166. Obraz cierpienia rodzicielki prześladował poetę $w$ więzieniu, co opisał w wierszu Dzwon wieczorny:

Moze tam na drugim brzegu

Moja matka opuszczona

We wiecznym legła noclegu

A nikt nie chodzi w zatobie ${ }^{167}$.

162 Ibidem.

16.3 Por. wiersz Dwie gwiazdki.

in A. A. Jakubowski, Poezje, s. 61.

16: Ibidem, s. 40.

16t M. Rosien ki e w'ic z, W'iadomość biograficzna..., s. 67.

16: A. A. Jakubowski, Poezje, s. 33. 
Powracał do niego również na wygnaniu:

Moja matka w starym lesie

Gdzieś przeklina świat,

Że jak wicher po nim niesie

Jej kochany kwiat ${ }^{168}$.

Jarosław Ławski podejrzewa, że Jakubowskiemu trudno było przenieść uczucie $\mathrm{z}$ matki na inną kobietę. Wydaje się to prawdopodobne, ale tylko w podolskim okresie przed wygnaniem. Figura "lubej” zawsze pojawia się bowiem w konwencjonalnych ujęciach nieszczęśliwej miłości. W wierszu Do Celiny uczucie zostato ukazane w sentymentalnych dekoracjach, natomiast liryk Ona przypomina wczesne utwory Mickiewicza, przedstawiające wybrankę jako famme fatale, która zamienia bohatera $\mathrm{w}$ upiora. $\mathrm{W}$ innych wierszach ukochana usycha $\mathrm{z}$ rozpaczy po wygnaniu lubego i gra tęskne dumki. Natomiast utwór Do... budzi skojarzenia z poezją legionową lub listopadową, w której bohater-żołnierz odrzuca zaloty dziewczyny, gdyż jego jedyną miłością staje się ojczyzna:

Gardzę mitością, lecz jeszcze została Jedyna miłość, której siostrą chwała, Której przedmiotem ojczyzna kochana,

To moja luba - to moja kochanka.

Ja - ona: razem swa istność zlewamy,

Za niq bym poszedt $w$ same piekta bramy,

Ona mi poda laurowego wiank ${ }^{169}$.

Uczucia $w$ poezjach Jakubowskiego zazwyczaj pozostają nieodwzajemnione, niespełnione, często niemożliwe do zrealizowania. Świat jawi mu się jako wroga przestrzeń, która pogłębia tylko jego alienację i samotność. Nie znajduje w nim zrozumienia, ale śmierć swoich pragnień. W Ideatach pisał podobnie również o ludziach:

Ach, po co szukać wpośród ludzi kwiatu,

Ach, po co szukać uczuć u świata,

I zimny szkielet tulic do tona? (...)

Bo tu szatany w ludzkiej postaci,

Tu gady, plazy bierzem za braci,

A braci serca jak mato. ${ }^{\text {70 }}$

Jakubowski ukazał w swojej poezji najważniejsze dla niego wartości, które na zawsze utracił: przede wszystkim Polskę, Podole i ukochaną matkę. Nie zdołał stworzyć nowych, które pozwoliłyby mu trwale zakorzenić się w miejscu wygnania, co tylko pogłębiało jego rozpacz i poczucie bezsensu życia. „Samotny wśród tłumu" i pozbawiony iluzji szczęścia pozostawił wiersze przeniknięte paraliżują- 
cym oddechem śmierci, obecnym w jego twórczości od najwcześniejszych prób poetyckich. Kres życia jawił mu się jako koniec cierpień i upragniona cisza, gdy nie odzywają się już żadne palące uczucia, myśli ani wspomnienia, od których bezskutecznie próbował się uwolnić. Wydaje się, że ciągle w nim obecne poczucie straty i pustki, których nie udało mu się niczym zapełnić, przyczyniło się do ostatecznej autodestrukcji oraz targnięcia się na własne życie.

Zarówno Julian Maślanka, jak i Jarosław Ławski pisali o autentyzmie i szczerości utworów młodego wygnańca. Dlatego też tak silne wrażenie robi Dumanie $I V$, pisane zapewne w chwili najgłębszej rozpaczy, przed samobójczym wystrzałem z pistoletu. Utwór ten kumuluje dotychczasowe katastroficzne tendencje i obsesyjne motywy śmierci w twórczości Jakubowskiego. Pogrążony w nieprzeniknionych ciemnościach, z sercem porównanym do "kamienia cmentarnego z szczątkami szczęścia” poeta był przekonany o bezsensie ludzkiego istnienia. „Ja” liryczne przypomina upiora, choć nigdzie nie pada to określenie wprost. „Zimne serce, wypalone oko" - świadczą o braku uczuć i zupełnym zamknięciu na zewnętrzną rzeczywistość. Poeta, który już w Piramidach stwierdzał, że jest jak „pomnik gruzów i rozbicia”, teraz widział w sobie jedynie „szczątek” dawnej istoty. Jakubowski czuł się zdradzony i nie chciał dłużej żyć w świecie, który go oszukał i mamił fałszywymi obietnicami. Jeszcze w Pożegnaniu, mając wyruszyć do Ameryki, rozpaczał, że chciał „śpiewać pieśń nieśmiertelności”. W Dumaniu IV znowu podkreślił, że jest to niemożliwe. Uważał, że jego głos nie wpisuje się w harmonię świata, określał go jako „odszczepiony”. Rzeczywistość, podobnie jak dla Kleista, nie przedstawiała dla niego żadnej wartości.

W swoim ostatnim utworze odciął się nie tylko od świata, ale także od Boga. Według Juliana Maślanki wezwanie szatana miało na celu pokonanie wahania przed śmiercią. Wcześniej $\mathrm{w}$ jego utworach postać diabła pojawiała się tylko w związku z pragnieniem zemsty i „zgonu starego świata". Metafora „zwalonych ołtarzy" nie wydaje się być profanacją świętego miejsca, ale pokazaniem, że runęło wszystko, co stanowiło dla niego świętość i miało najwyższą wartość. Tym razem poeta świadomie wybierał potępienie, choć przeczuwał, że za grobem jego dusza nie znajdzie ukojenia. Ostatnie słowa liryku świadczą, jakim cierpieniem dla młodego wygnańca było życie, skoro uważał, że po śmierci nie może go spotkać nic gorszego: „Smutno po zgonie, nie smutniej jak w życiu” ${ }^{171}$. Niezwykle przejmująco brzmi ostatni znany wiersz Jakubowskiego, w którym w geście rozpaczy Kierkegaarda woła:

I czegoż jeszcze oglądasz się, czekasz?

Czego zalujesz? Czym gromów odwlekasz?

Uderz, ach uderz w szczatek twej istoty!

Nucil ci radość świat, gdyś byt w powiciu,

I świat cię zdradzit, a teraz w skonanie

Szatańskim głosem śpiewaj mi szatanie ${ }^{172}$. 


\section{The Exile's Song i It is weary - nieznane amerykańskie wiersze Jakubowskiego}

Nowe odkrycia za oceanem pozwalają dopisać kolejny rozdział o dorobku poetyckim Jakubowskiego. Okazuje się, że niezwykle rzadki reprint The Remembranes of a Polish Exile wydany w Auburn w 1835 roku skrywa w sobie prawdziwy skarb - dwa fragmenty ${ }^{173}$ prozy poetyckiej zatytułowane The Exile's Song oraz It is weary. Dzięki życzliwości Przemysława Jana Blocha dysponujemy zdjęciami oryginału, które zamieszczam poniżej:

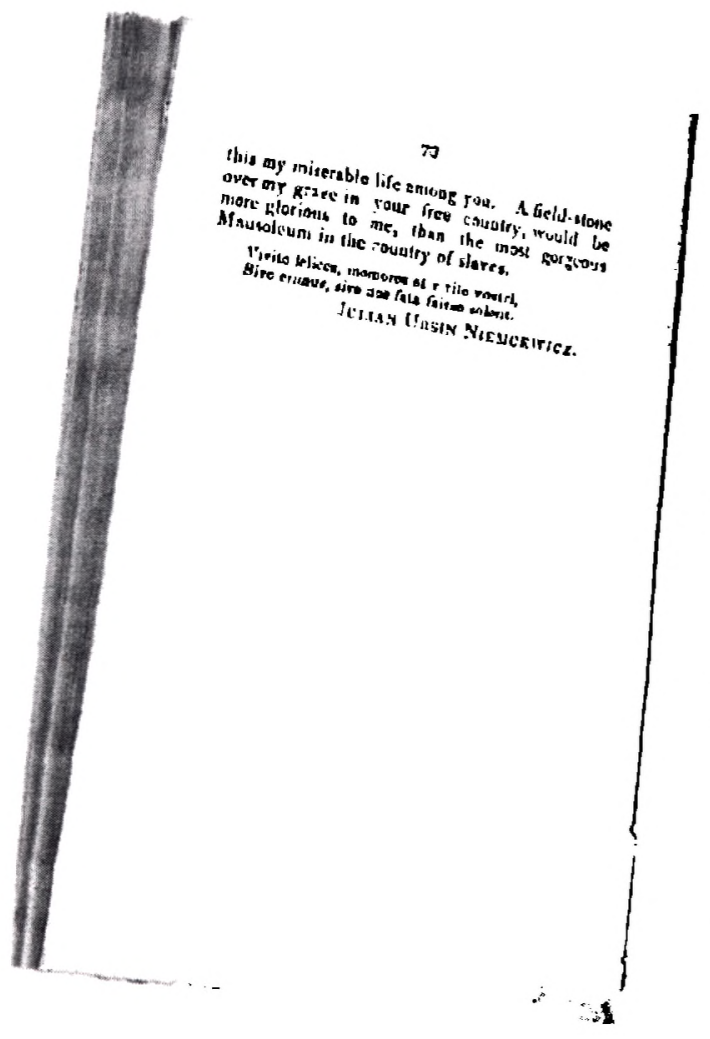

JHE E.X:LF:'S SOYSC.

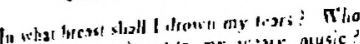

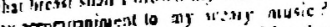

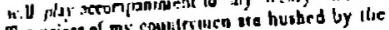

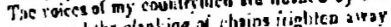
terant, ind the cianking or thans inighte and

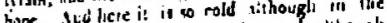

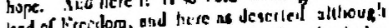

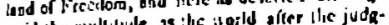

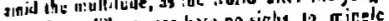

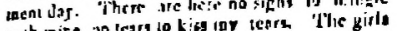

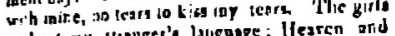
whe al aly shangti' lalgonge; llesren arid

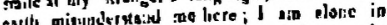

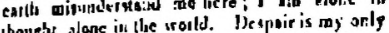
thought, alane in the woold. Detphir is my arilg fiveid, an ouly emapouman. I trilf fy tike

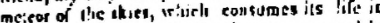

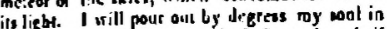
teare: Slie s!all dituppear io Peelong, ohe thail T) uray its song. But, ou! when the music of If log con is lushed, wo brest will echo back

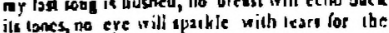
bir inger.

IT :S WE.IRY.

If is reary, it is weery to the riads to blow over 'he deven, but more werry to the gouth to esut up lus forings i: hib ona ?enn, to Gad no

${ }^{173}$ Mieczyslaw Giergielewicz, omawiając uklad The Remembrances..., jedynie wspominał o istnieniu It is weary oraz The Exile's song, ale nie pisal o nich nic więcej, por. M. Gi e r g i ele wicz, op. cit., s. 69. 


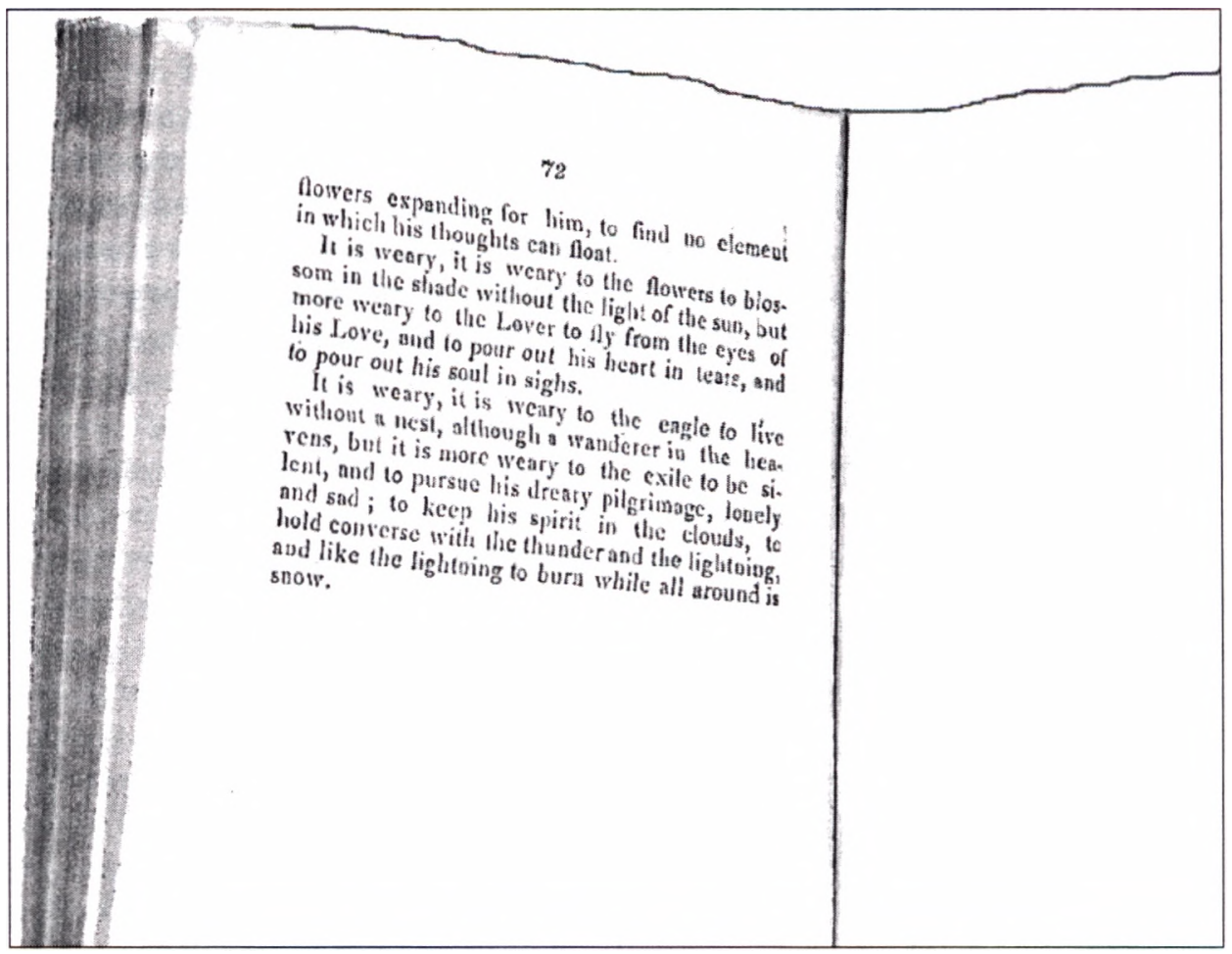

Znajdujące się tu utwory, chociaż niepodpisane, niewątpliwie są autorstwa Jakubowskiego. Cechuje je ciągły zapis bez wersyfikacyjnego podziału jak poème en prose. Trudno ustalić, czy mamy do czynienia $\mathrm{z}$ angielskim oryginałem, czy też translacją polskiego pierwowzoru. Fragmenty te wypełniają lukę $w$ obrazie ostatniego, amerykańskiego etapu twórczości Jakubowskiego. W najwyższym też stopniu kumulują wszystkie jego charakterystyczne nastroje - mortualne, melancholijne, katastroficzne (bardziej nawet niż Dumanie IV), jak również astralne motywy patriotyczne, a także florystyczne, co wyraźnie widać po przełożeniu ich na ojczysty język autora:

\section{THE EXILE'S SONG}

In what breast shall I drown my tears? Who will play accompaniment to my weary music? The voices of my countrymen are hushed by the tyrant, and the clanking of chains frighten away hope. And here it is so cold although in the land of Freedom, and here as deserted although amid the multitude, as the world after the judgment day. There are here no sighs to mingle with mine, no tears to kiss my tears. The girls smile at my stranger's language. Heaven and earth misunderstand me here. I am alone in 
thought, alone inthe world. Despair is my only

friend, my only companion. I will fly like a meteor of the skies, which consumes its life in its light. I will pour out by degress my soul in tears: She shall disappear in feeling she shall fly away in song. But, oh! when the music of my last song is hushed, no breast will echo back its tones, no eye will sparkle with tears for the stranger.

\section{PIEŚŃ WYGNAŃCA}

W czyjej piersi utopię me łzy? Któż zawtóruje mej znużonej muzyce?

Glosy mych rodaków uciszone przez tyrana, brzęk lańcuchów płoszy nadzieję. I tak tu zimno mimo iż w krainie Wolności i tak opuszczony pomimo tłumów, jak świat po dniu sądu ostatecznego. Nie masz westchnień by mieszały się z mymi, nie ma łez całujących łzy moje. Dziewczęta uśmiechają się na mój język obcego. Niebo i ziemia nie pojmują mnie tutaj. Samotny jestem w myślach, samotny w całym świecie. Rozpacz jest mym jedynym druhem, jedynym towarzyszem. Polecę przez niebo niczym kometa, która kończy swój żywot w swym blasku. Stopniowo rozleję swą duszę we łzach: ona zniknie w uczuciu, uleci z pieśnią. Ale och! Kiedy ucichnie dźwięk mej ostatniej pieśni, żadna pierś nie odpowie jej echem, żadne oko nie błyśnie łzą za obcego ${ }^{174}$.

\section{IT IS WEARY}

It is weary, It is weary to the winds to blow over the desert, but more weary to the youth to shut up his feelings in his own heart, to find no flowers expanding for him, to find no element in which his thoughts can float. It is weary, it is weary to the flowers to blossom in the shade without the light of the sun, but more weary to the Lover to fly from the eyes of his Love, mid to pour out his heart in tears, and to pour out his soul in sighs.

It is weary, it is weary to the eagle to live without a nest, although a wanderer in the heavens, but it is more weary to the exile to be si- 
lent, and to pursue his dreary pilgrimage, lonely and sad; to keep his spirit in the clouds, to hold converse with the thunder and the lightning, and like the lightning to burn while all around is snow.

\section{JAK NUŻĄCE}

Jak nużące, jak nużące jest wiatrowi wiać ponad pustynią, choć bardziej nużące jest młodzieńcowi zamknąć swe uczucia w swym sercu, nie znaleźć żadnych kwiatów rozwijających się dla niego, nie znaleźć żywiołu zdolnego unieść jego myśli.

Nużące jest, nużące jest kwiatom kwit-

nąć $w$ cieniu bez światła słońca, ale bardziej nużące jest Kochankowi uciekać $z$ oczu swojej Miłości i wylewać swe serce w łzach i wylewać swą duszę w westchnieniach.

Nużące jest, nużące jest orłu istnieć bez gniazda, niby wędrowiec $w$ przestworzach, ale jeszcze bardziej nużące jest milczeć wychodźcy i wypełniać swą ponurą pielgrzymkę, samotny i smutny; trzymać swego ducha w chmurach, prowadzić rozmowy z gromem i piorunem i jak piorun spalać się wśród śniegów dookoła.

Utwory te są świadectwem skrajnej alienacji, krzykiem rozpaczy i braku nadziei. W kraju wolności Jakubowski paradoksalnie czuje się jak w więzieniu. Odkąd został aresztowany i oddzielony od ojczyzny oraz rodziny, cały świat jawi mu się jako egzystencjalny stan uwięzienia, z którego uwolnić można się tylko przez śmierć. W żadnym wierszu Jakubowskiego rozpacz nigdy nie została wyrażona tak bezpośrednio, jak w The Exile's Song. Pobrzmiewa w nim tonacja ostatecznej katastrofy - apokalipsy. Bohater doświadcza totalnego wymiaru samotności: nie tylko staje się samotny wśród tłumu, ale cała przestrzeń wygnania jawi mu się jako obca, zimna i wroga - „niebo i ziemia nie rozumieją mnie tutaj. Jestem samotny myślą, samotny w świecie". Poetyckie imaginarium kosmiczne zyskuje nowe horyzonty - „ja" liryczne staje się samotną planetą we wszechświecie, dotkliwie odczuwa swoją alienację nie tylko wśród ludzi, ale także wobec Boga. W świecie poezji Jakubowskiego daje się odczuć brak wiary w Bożą opatrzność, niczym w Marii niebo pozostaje zamknięte na westchnienia bohaterów.

W kompozycji ramowej utworu pobrzmiewa skarga na brak powiernika, osoby obdarzonej empatią, której można powierzyć swoje uczucia i refleksje. Nie ma nikogo, kto „da akompaniament (...) nużącej muzyce” młodzieńca. Pieśń wygnańca w niczym nie przypomina "pieśni nieśmiertelności”, o której marzył podmiot liryczny wczesnych wierszy Jakubowskiego, ale śpiew łabędzia. Choć w The Exile's Song nie ma dosłownej zapowiedzi samobójstwa, uwidacznia się pewność rychłej 
śmierci w metaforyce podobnej do sonetu - Do J.B. Kiedy w polskim wierszu „ja” liryczne porównuje się do zgasłej komety ${ }^{175}, w$ angielskim utworze pojawia się podobne wyznanie: Polecę przez niebo niczym kometa, która kończy żywot w swoim blasku. W Ideatach, najprawdopodobniej pisanych w Polsce, również powraca ten sam motyw skojarzony z przemijaniem w mgnieniu oka, pojawieniem się i szybkim zniknięciem:

Ten szczęsny, smutki ziemskie nie ćmia jego skroni,

Lub choć przyjda, to znikna jako meteory ${ }^{176}$.

Natomiast w układzie The Remembrances... pieśń wygnańca tworzy razem $\mathrm{z}$ dedykacją kompozycję ramową (exile sings his song unworthy it might be [wygnaniec śpiewa swą pieśń, niewiele wartą pewnie]) całego dzieła. Mimo osobistego tonu utwór staje się po części zapisem ogólnego doświadczenia polskich tułaczy zmuszonych udać się za ocean. O chłodzie ziemi wolności pisał również Marcin Rosienkiewicz:

Trudno jest opisać (...), jak ciężko w tym kraju przy najlepszych nawet chęciach pracować i osiagnać cel pracy, we względzie naszej narodowości. Co krok, to przeszkoda. Naród kupiecki, zimny, chciwy, któremu dolar jest bogiem, cnota, uczuciem - na wszystko jest obojętny, co nie przynosi materialnej korzyści ${ }^{177}$.

Ostatni akord pieśni wygnańca, odseparowany od reszty tekstu, dobitnie streszcza dramat zesłańca: zawsze będzie on obcy.

Jarosław Ławski podejrzewa, że Jakubowski zabił się nie w chwili największej rozpaczy, ale „znużenia”"178, gdy życie stało się dla niego nie do zniesienia. Ostatni angielski utwór poety It is weary wypływa właśnie $\mathrm{z}$ doświadczenia tego stanu psychicznego. W swojej konstrukcji i wymowie nasuwa podobieństwa $z$ drugą częścią Dumania I:

Tęskno jest, gdy na wiosnę wcześnie więdną kwiaty

I zostawiaja samotne kwatery ogrodu

Tęskniej, gdy myśl, co miała lecieć w górne światy,

Skrępowana tańcuchy umiera za mtodu ${ }^{179}$.

W dotychczasowej liryce Jakubowskiego „myśl” dokonywała transgresji, wznosiła się, by zaraz upaść - tutaj panują bezruch, martwota i cisza. Wiersz ukazuje stan zupełnej rezygnacji, wypalenia. Przywodzi na myśl krajobraz Marii,

175 W wierszu Ideaty kometa przyrównana jest do natchnienia, jawi się jako „cud nadświatowej natury”, która wylatuje „ponad światy”, na chwilę ukazuje się poecie i „znika jak blyskawica”.

176 A. A. Jakubowski, Poezje, s. 24.

17 List M. Rosienkiewicza do K. Lacha Szyrmy z 9.05.1836, „Kronika Emigracji Polskiej”, vol. 6, Paryż 1837, s. 261.

${ }^{17 *}$ J. Ła w ski, Siedem. O Auguście Antonim Jakubowskim, [w:] Nihilizm i historia. Studia z literatury XIX i XX wieku, red. M. Sokolowski, J. Ławski, Białystok - Warszawa 2008, s. 22, Czarny Romantyzm.

179 A. A. Jaku b owski, Poezje, s. 48. 
gdzie „wzrok daleko, próżno błądzi po równinie” ${ }^{180}$, „włóczy się (...) w przestrzeni, lecz gdzie tylko zajdzie,/ Ni ruchu nie napotka, ni spocząć nie znajdzie"181. Podobnie Jakubowski nie znajduje niczego, co mogłoby go zatrzymać przy życiu, czegoś, na czym jego myśl mogłaby się oprzeć (to find no element in which his thoughts can float) i znów „lecieć w górne światy”. Co zatem jej pozostaje? „Po polach błądzi nie wsparłszy się na nic,/ Jak Rozpacz - bez przytułku - bez celu bez granic” - odpowiada ojciec. Wtóruje mu syn: „Rozpacz jest moim jedynym przyjacielem, jedynym towarzyszem".

Pejzaż wewnętrzny „ja" lirycznego It is weary to martwa pustynia, nie pomoże jej ożywczy wiatr, nigdy nie wyrosną na niej kwiaty. Florystyczna topika, tak typowa dla Jakubowskiego, pojawia się dwukrotnie - jako symbol zrabowanego szczęścia oraz zatrutej młodości, która musi dojrzewać w cieniu, bez promieni słońca. „Kwiat mego życia zjadłe stoczyły robaki"182 - powie w innym wierszu.

Tak jak w The Exile's Song powraca motyw alienacji, braku bliskiej osoby, przy której można zrzucić maskę pogodnego filozofa, pocieszającego współwygnańców i powierzyć jej swoje prawdziwe rozterki. Autor w obu utworach w takich samych słowach wyraża żal, że nie ma przy nim ukochanej, z którą mógłby łączyć swoje łzy i westchnienia. Jakubowski również w przedmowie do The Remembrances pisał o traumie niewysłowionego cierpienia, z którym trudno mierzyć się samotnie. Dlatego po raz kolejny zamyka uczucia we własnym sercu, co przynosi mu ostateczne znużenie duchowe. W całym utworze, w gradacji wprowadzonej przez Jakubowskiego, źródłem największego bólu dla wygnańca jest właśnie zamilknąć.

Estetyka wyobraźni Jakubowskiego przypomina słowa epitafium Niemcewicza, które ułożył on sam na krótko przed swoją śmiercią:

Oh! ye exiles who so long wander over the earth, Where will you find a restingplace for your weary feet? The wild dove has its nest, and the worm a clod of earth, Each man has a country, The Pole has but a grave ${ }^{183}$.

Zarówno u Niemcewicza, jak i u Jakubowskiego pojawia się kategoria znużenia oraz zupełnej bezdomności obrazowanej w podobny sposób (ptak pozbawiony gniazda). Autor Śpiewów historycznych zaznacza, że wygnaniec nie ma swojego miejsca, nigdzie nie jest u siebie, a jedyne, co go czeka na końcu jego wędrówki, to grób. Natomiast Jakubowski widzi konieczność śmierci jako jedyne wyjście z błędnego koła losu tułacza, które jest dla niego nie do zniesienia. Młody poeta jest osaczony przez pustkę, nie ma już żadnego terytorium wewnętrznego,

${ }^{1 \times()}$ Antoni Malczewski, jego żywot i pisma ozdobione popiersiem, red. A. B i elowski, Lwów 1843, p. II, w. 641, s. 57.

Ik1 Ibidem, p. I, w. 167, s. 35.

1 1k2 A. A. Jakubowski, Poezje, s. 48.

1k:3 Thumaczenie: Och! Wy wygnańcy, którzy tak dlugo błądzicie po ziemi, Gdzie znajdziecie miejsce odpoczynku dla waszych znużonych stóp? Dziki gołąb ma swe gniazdo, robak grudę ziemi, każdy człowiek swój kraj, a Polak grób tylko, N. O. W i n t e r, Poland of To-Day and Yesterday. AReview of its History, Past and Present, and of the Causes which Resulted in its Partition, Together with a Survey of its Social, Political, and Economic Conditions To-Day, Boston 1913, s. 230. 
jakie nie byłoby opanowane przez smutek. Nie potrafi odnaleźć się w nowej przestrzeni, która nigdy nie zastąpi mu ojczyzny. Nie może zakorzenić się w miejscu, gdzie czuje się tak obco. Już w Pożegnaniu przyrównywał się do orła próbującego lecieć pomimo krępujących kajdan. Paradoksalnie w ziemi wolności uświadamia sobie, że jego lot nie jest możliwy, ponieważ nie posiada gniazda, do którego mógłby wracać. „Podniebny wędrowiec” nie ma żadnej ostoi, wytchnienia w swoim cierpieniu i wartości, które trzymałyby go przy życiu. W rzeczywistości on sam nie może uwolnić się z lańcuchów swojej tanatycznej obsesji i wrodzonego pesymizmu, jakie tylko nasiliły się pod wpływem zesłania do Ameryki. W jednym $\mathrm{z}$ wierszy autor, przyrównując się do kwiatu, wyznawał:

Lecz się zabójczy robak gnieździ w twym korzeniu;

Równie zabójczy robak żyje w mym wspomnieniu,

Wraz ze mną się urodzit $i$ wraz ze mną zginie ${ }^{184}$.

To zarażenie śmiercią sprawia, że nie czuje on żadnej więzi ze światem, co również ma związek ze wspomnianą koncepcją wyalienowanej jaźni, niemogącej wyjść poza własne projekcje. Jest to inne zmęczenie niż to, o którym pisał Norwid do Augusta Cieszkowskiego: „Jestem zmęczony (...), zmęczony czasowo skutkiem walk nieułatwionego niczym życia"185. Świat nie odpycha Jakubowskiego, wręcz przeciwnie - swoją ujmującą postawą i czarującą osobowością poeta zjednuje sobie wszystkich spotkanych Amerykanów, otwiera się też przed nim dobrze zapowiadająca się kariera literacka. To on ucieka od rzeczywistości, a mimo to w It is weary nie ma buntu, gniewu czy złorzeczenia, ale rezygnacja, utrata sił i swoista acedia. Do tej pory w liryce Jakubowskiego pojawiała się „burzowa metaforyka”, taka jak "piorun zemsty", obecna w wierszach Alopeus i Tułacz, czy też grom jako prześladujące wspomnienie w Dumaniu III. Natomiast w It is weary pierwszy raz syn Malczewskiego sięga po motyw błyskawicy jako symbolu samozniszczenia. Poeta, którego „cechuje upodobanie do astralnej wzniosłości”186, pokazał w tych dwóch amerykańskich wierszach kosmiczne ujęcie śmierci, pokrewne częstym motywom spopielenia i gaśnięcia w jego liryce. Figura losu meteoru i błyskawicy wyróżnia się tym, że zaraz po chwili narodzin następuje śmierć, rozbłysk i momentalne pogrążenie w mroku. Nieprzypadkowo płomień ten bucha w lodowej scenerii. Podobna sytuacja liryczna występuje w pierwszym z dumań pisanym na Gibraltarze - granicy między domem-Europą a obcą i wrogą przestrzenią. Dumanie I stało się także granicą w liryce Jakubowskiego, przenikniętej odtąd paraliżującym powiewem śmierci i nieuchronnym do niej dążeniem bez cienia nadziei. Jaskrawy kontrast pomiędzy wewnętrznym światem podmiotu a rzeczywistością

144 A. A. Jakubowski, Poezje, s. 51.

ins List do A. Cieszkowskiego, [w:] C. Nor wid, Pisma wszystkie, t. 10, red. J. W. G o muli cki, Warszawa 1971, s. 118.

IH6 J. La a ski, W romantycznym „mroku gwiazd”. Wyobraźnia katastroficzna Augusta Antoniego Jakubowskiego, [w:] Poezja i astronomia, red. B. B u rd z i e j, G. Ha lk i e w i c z-S oj a k, Toruń 2006, s. 206. 
zewnętrzną (np. śnieg u wybrzeży Afryki w Dumaniu I) pokazuje skrajną alienację, a także autodestrukcyjną siłę naduczucia i obsesji śmierci. To do niej prowadzi "samotna i ponura" pielgrzymka, o której wspomina Jakubowski w It is weary.

Prawdopodobnie utwory Jakubowskiego napisane $w$ języku angielskim przeniknęły do społecznego obiegu. Potwierdzenie tej tezy udało mi się odnaleźć w jednym z przypisów w Polskiej emigracji politycznej w Stanach Zjednoczonych Ameryki 1831-1864 Floriana Stasika. Autor jako przykład pełnych rozpaczy wierszy polskich wygnańców w Stanach Zjednoczonych przytoczył po polsku taki oto nieznany dotąd wiersz Jakubowskiego:

I tak tu zimno, choć w wolności kraju, I tak tu ciemno, choć stonce na niebie, I tak tu pusto wśród kwietnego maju Jak po dniu sadu, po świata pogrzebie...

Każa mój umyst podnosić do Boga,

Dumne kolana przygniatać do ziemi,

Lecz moje modty rozproszyta trwoga,

Lecz Bóg uleciat $z$ westchnieniami mymi ${ }^{187}$.

Stasik nie podał tytułu ani informacji, czy utwór ten został przetłumaczony przez niego, czy też przytoczył go za oryginałem. Zamieścił jedynie źródło tekstu: „Muz. Pol. Chic., Rkps 2506 (Rap.) ${ }^{188 ”}$. Cztery pierwsze wersy wyraźnie nawiązują do The Exile's Song, pierwszy i ostatni z nich jest dokładnym tłumaczeniem amerykańskiego utworu. Natomiast dystych pomiędzy nimi został zbudowany na zasadzie paralelizmu składniowego analogicznego do samego początku wiersza. Podobny zabieg Jakubowski zastosował w It is weary. Dalsza część utworu przytoczonego przez Stasika nie pokrywa się z żadnym znanym utworem syna Malczewskiego, budzi jednak skojarzenia z bardzo osobistym i przejmującym Dumaniem IV. Ważniejsze jest jednak to, że jest to jeden z nielicznych wierszy, w których Jakubowski przywołuje postać osobowego Boga, jeśli to on sam nadał ostateczny kształt cytowanemu tekstowi.

W The Exile's Song oraz w It is weary pojawiają się poza tym motywy miłosne. Podczas gdy w polskich lirykach powracała dość konwencjonalna postać bliżej nieokreślonej lubej, porzucanej w imię Ukochanej - Ojczyzny, w utworach amerykańskich pobrzmiewa osobisty ton zawiedzionej miłości, szczególnie $\mathrm{w}$ The Exile's Song. Przebija z niego żal, że „Damy Ameryki”, którym dedykował swoje The Remembrances..., nie wsłuchują się $\mathrm{w}$ jego słowa, a jedynie uśmiechają na dźwięk zabawnego, wciąż trochę nieporadnego cudzoziemskiego języka poety.

Czy jednak rzeczywiście nie było w Ameryce żadnej kobiety, która odpowiedziałaby echem na łzy i westchnienia młodego wygnańca? Dzięki zbiorom Prze-

1k7 F. S t a s i k, Polska emigracja polityczna w Stanach Zjednoczonych Ameryki 1831-1864, Warszawa 1973, s. 117.

Ikx We wspomnianym przypisie pojawia się wzmianka, że na karcie czwartej tego rękopisu znajdują się „różne pieśni patriotyczne, wiersze satyryczne i aktualne z czasów rewolucji listopadowej i emigracji we Francji". 
mysława Jana Blocha możemy zaryzykować hipotezę, że odnaleźliśmy muzę Jakubowskiego - jego uczennicę z Northampton - Julię Bowers ${ }^{189}$, córkę dyrektora Gothic Seminary, Henry'ego G. Bowersa. Zastanawiające jest to, że niedługo po samobójstwie Jakubowskiego rodzina Bowersów przeniosła się do Alton w stanie Illinois. Henry Bowers przestał też pełnić funkcję dyrektora Seminarium Gotyckiego.

\section{Julia R. Bowers - amerykańska muza Jakubowskiego?}

Syn Malczewskiego musiał być osobą wyjątkową. Wszystkie zachowane świadectwa ludzi, którzy się z nim zetknęli, pokazują, że polski wygnaniec swoim ujmującym zachowaniem, wiedzą i osobistym urokiem robił na nich najlepsze wrażenie. Nawet szpecący garb, będący skutkiem gruźlicy kręgosłupa, nie przeszkodził mu w karierze. Mimo ciężkiej choroby otrzymał posadę w najbardziej prestiżowej szkole dla dziewcząt w Stanach Zjednoczonych oraz pośredniczył w dwóch wznowieniach swojego The Remembrances..., które cieszyły się coraz większą popularnością. Należy podkreślić, że wydawnictwo Shermana, które opublikowało w 1835 roku tomik Jakubowskiego, miało w tamtym czasie ogromną renomę.

Heroizm poety w znoszeniu kolejnych przeciwności losu, jego tragizm osobisty i narodowy, a także czarująca osobowość czyniły go atrakcyjnym dla amerykańskich dam, którym zadedykował zresztą Wspomnienia polskiego wygnańca. Mężczyzną „bardzo interesującym” nazwała go jego uczennica Mary Pierce-Poor, której Jakubowski miał złożyć kurtuazyjną wizytę podczas nieobecności jej ciotki w 1836 roku. Clarissa Stebbins zanotowała w swoim szkolnym katalogu, że poeta był przez wszystkich kochany, ale najbardziej przez Julię Bowers. To właśnie Julia napisała przejmujący wiersz upamiętniający zmarłego Jakubowskiego. Koresponduje on $\mathrm{z}$ adresowanym do niej utworem poety pt. Do J.B., będącym zarazem wyznaniem miłości, jak i przeczuciem zbliżającej się śmierci. Nieprzypadkowy wydaje się również fakt, że najlepszy przyjaciel Jakubowskiego Napoleon Kościałkowski zadedykował egzemplarz The Remembrances... kolejnej wychowance Jakubowskiego - Lucy E. Dewey. Dodajmy, że to właśnie w kwaterze rodzinnej Dewey'ów na cmentarzu przy Bridge Street spoczął Jakubowski...

1k9 Julia Russell Bowers, (1821-1879), córka Henry'ego G. Bowersa (1790-1840) i Lucy W. Russell (1791-1825), to ciekawa postać. Jej ojciec, emer ytowany bogaty nowojorski kupiec, pochodzący z Wirginii, po śmierci żony przeniósł się wraz z ośmiorgiem dzieci z Nowego Jorku do Northampton w 1826 roku. Bowersowie wybudowali w Northampton okazaly palac, kilkaset metrów od Gothic Seminary, a sam Henry Bowers w 1836 i 1837 roku był dyrektorem tej szkoly. Do Seminarium Gotyckiego uczęszczały jego trzy córki: najstarsza Julia i dwie młodsze, Frances i Grace. W połowie 1837 roku rodzina przeniosła się do Alton w stanie Illinois.

Mieszkając już w Alton, Julia Bowers wydała w latach 40. XIX wieku kilka swoich wierszy w antologiach ówczesnej poezji. Po ślubie w 1849 roku z pastorem doktorem Sterlingiem Yancey McMasters przeniosła się do St. Paul w Minnessocie, gdzie nadal pisała wiersze. Ich tomik Silver Pictures, zawierający treny po śmierci jej córki, wydała w 1856 roku w Filadelfii. 
W kolekcji mecenasa Blocha znajduje się wyjątkowy egzemplarz The Remembrances z 1835 roku zawierający dedykację Kościałkowskiego właśnie dla Lucy Dewey, a na tylnej okładce ma wklejony wiersz-epitafium Podolia's Exiled Child napisany kobiecą ręką i podpisany przez... Julię Bowers!

\section{Podolia's Exiled Child}

Far from where blooms his native rose,

And dearest kindred smile,

The grave protects in sweet repose,

Podolia's exiled child.

So the valley's sod we bore him,

Where the pines in music were,

And the evening breezes wafted,

O'er the Polish exile's grave.

And in his youthful beauty,

Like a dream he passed away,

Like the early blighted flower,

Which blushes for an hour.

Oft in the vesper twilight,

When the evening Zephyrs sigh,

We think of that sad fated one,

So early doomed to die.

But one like a losed bighten,

Stand over his dying bed,

To bear to his distant mother,

The tidings he's dead.

And now to his place of lonely rest,

We bring sweet blushing flowers,

And hope the gentle spirits bless him,

In ever blooming bowers.

\section{J.R. Bowers}

Podola wygnane dziecie

Daleko od jego kwitnącej róży rodzimej,

I najdroższej rodziny uśmiechu,

Mogiła w słodkim spoczynku chroni,

Podola wygnane dziecię.

Więc przynieśliśmy mu darń $\mathrm{z}$ doliny,

Gdzie sosny muzyką były,

I wieczora podmuchy unosiły się,

Nad polskiego wygnańcy mogiłą. 
I w swej mlodzieńczej urodzie,

Jak sen przeminął,

Jak wcześnie zerwany kwiat,

Który kwitnie przez godzinę.

Często o zmierzchu nieszporów,

Kiedy wieczorne zefiry wzdychaja,

Myślimy o smutnym losie tego,

Tak wcześnie skazanego na śmierć.

Ale tak jak rozwiązana pętla,

Stojąc nad jego łożem śmierci,

By zanieść jego oddalonej matce,

Wieść, że nie żyje.

A teraz do samotnego miejsca jego spoczynku,

Przynosimy słodkie rumiane kwiaty,

W nadziei, że łagodne duchy będą go błogoslawić,

W wiecznie kwitnących altanach ${ }^{190}$.

\section{J.R. Bowers}

Podola wygnane dziecię świadczy o dużej wrażliwości, a także znajomości twórczości samego Jakubowskiego. W utworze tym uderza obecność motywów najbardziej charakterystycznych dla polskiego poety. Od samego początku autorka zarysowuje największy dramat wygnańca - oddzielenie go na zawsze od ukochanego kraju i rodziny. Nieprzypadkowo wspomina właśnie o „oddalonej matce” Augusta Antoniego, którą „nad życie ubóstwiał” i cały czas za nią tęsknił. Imię Julia nadał matce głównego bohatera autobiograficznej powieści Major Aleksander, pisanej ponoć już po angielsku.

Wiersz-epitafium Julii sprzeciwia się puencie The Exile's Song. Pokazuje, że tylko połowicznie spełniły się najgorsze przeczucia, a zarazem obsesje Jakubowskiego - jego grób znalazł się wprawdzie w obcej ziemi, jednak poeta nie został zupełnie zapomniany, a jego krótkie życie nie przeszło bez echa. Julia niezwykle trafnie ujęła jego istotę - jako ciążącego nad nim fatum, nieuchronnego wyroku, od którego nie ma ucieczki. Zamiast autodestrukcyjnej, werteryzującej osobowości dwukrotnie pokazuje fatalną siłę, która za wcześnie zrywa kwiat życia młodzieńca. Przejmująco brzmią słowa: Często o zmierzchu nieszporów/ (...) Myślimy o smutnym losie tego,/ Tak wcześnie skazanego na śmierć.

Dziewczyna musiała być świadoma wielkiego cierpienia, z jakim wiązało się dla Jakubowskiego życie na wygnaniu, stąd jego ostateczny krok w stronę samozatraty i przekroczenie progu nicości opisuje w kategoriach ulgi i wyzwolenia przyrównuje śmierć poety do rozwiązanej pętli i słodkiego spoczynku. 
Zapewne nieprzypadkowo Bowers nasyca swój utwór ulubioną florystyczną topiką jej nauczyciela. Jakubowski w swojej liryce kojarzył kwiat z witalnością, szczęściem, marzeniem i dzieciństwem. Sam w Dumaniu I przyrównywał się do rośliny, która przeniesiona $\mathrm{z}$ rodzinnej ziemi usycha w obcych stronach. W Podolia's Exiled Child możemy przeczytać:

I w swej miodzieńczej urodzie,

Jak sen przeminat,

Jak wcześnie zerwany kwiat, który kwitnie przez godzinę.

Wspominałam już o liryce epicedialnej francuskiej Plejady i przekonaniu, że życie kwiatu trwa od wschodu do zachodu słońca, co symbolizowało kruchość i nietrwałość ludzkiej egzystencji. Metafora Bowers pokazuje rozpaczliwie krótki czas szczęścia i życia poety. W kolejny zwrotkach powracają słowa: So early [tak wcześnie].

Niewątpliwie Julia miała wiedzę wykraczającą poza zwykłą relację łączącą uczennicę i nauczyciela. Jej wiersz świadczy o ich bliskości duchowej, być może ostatni wers utworu jest zaszyfrowanym wyznaniem miłosnym. W angielskim oryginale autorka zawarła swój podwójny podpis, pisząc własne nazwisko dokładnie pod ostatnim słowem końcowej linijki: in ever blooming bowers. Oczywiście może być to przypadek, ale niewykluczone, że był to świadomy zabieg dziewczyny, która sięgając po ulubiony motyw Jakubowskiego, dała wyraz swojemu uczuciu w zawoalowanej formie. A może było po prostu tak, jak pisał sam poeta w Dumaniu I:

Tęskno jest, gdy na wiosnę wcześnie więdną kwiaty

I zostawiaja samotne kwatery ogrodu $u^{191}$. 


\section{The Remembrances of a Polish Exile - pierwsza próba syntezy polskich dziejów i antologia ojczystej poezji w Ameryce}

\section{Dzieto znamionujace geniusza. Zarys i budowa The Remembrances of a Polish Exile}

The Remembrances of a Polish Exile to dzieło wyjątkowe nie tylko w twórczości Jakubowskiego, ale również w zagranicznej recepcji literatury polskiej. Wydane w 1835 roku w Filadelfii, stanowi jednocześnie pierwszą antologię naszej poezji, a także pierwszą publikację o polskiej kulturze, historii i edukacji w języku angielskim wydane w Ameryce. Cytowane przeze mnie fragmenty oryginału przytaczam w przypisach, a w tekście głównym dokonuję ich translacji.

Przed Jakubowskim po angielsku o literaturze polskiej pisał jedynie Krystyn Lach Szyrma, który w 1823 roku wydał w Edynburgu słynne Letters Literary and Political on Poland. Listy te zostały uznane „za pierwszą w języku angielskim syntezę dziejów kultury i literatury polskiej i słowiańskiej"192. Właśnie tą pracą zainspirował się John Bowring, który wkrótce postanowił wydać pierwszą antologię polskiej poezji przełożoną na język angielski. Do wszystkich utworów, jakie przetłumaczył, miał dostęp $w$ oryginale, a czasem korzystał z prozatorskich parafraz Szyrmy.

Zarówno Bowring, jak i Szyrma mieli ponad trzydzieści lat w chwili tworzenia swoich dzieł. Posiadali oni nie tylko ugruntowaną wiedzę, ale dogodniejsze niż Jakubowski warunki - dostęp do omawianych przez siebie utworów. Natomiast August Antoni nie miał jeszcze dwudziestu lat, gdy zdecydował się napisać The Remembrances... Z powodu wybuchu powstania listopadowego nie ukończył kursu w Liceum Krzemienieckim. W odróżnieniu od swoich poprzedników, nie miał też wglądu w źródła naukowe, które mogły być mu pomocne. Korzystał jedynie $\mathrm{z}$ własnej pamięci (podkreślał to nie tylko sam autor, lecz również William Buell Sprague w przedmowie do The Remembrances... oraz Rosienkiewicz w Wiadomości biograficznej).

${ }_{142}$ A. Kow a l sk a, John Bowring. Ttumacz i propagator literatury polskiej w Anglii, Łódź 1965, s. 60, Prace Wydziatu I Jezzkoznawstwa, Nauki o Literaturze i Filozofii - Łódzkie Towarzystwo Naukowe, $\mathrm{nr} 62$. 
Wspomniane Letters and Literary... oraz Speciments of Polish Poetry cieszyły się dużą renomą. W 1828 roku na łamach „North American Review” W. B. Peabody umieścił pozytywną recenzję dzieła Bowringa, a także kilka jego przekładów. Jednak mało prawdopodobny wydaje się fakt, aby Jakubowski korzystał $\mathrm{z}$ tych tekstów przy pracy nad The Remembrances..., o czym wspomniał również Eugeniusz Żuk ${ }^{193}$. Z jednej strony dzieła te reprezentują szersze spojrzenie na polską literaturę i kulturę, a ich analiza jest bardziej pogłębiona. Warto jednak zaznaczyć, że mimo sprzyjających okoliczności Szyrma dokonał jedynie drobnych, fragmentarycznych tłumaczeń polskich utworów. To, co nie udało się jemu, osiągnął dużo młodszy Jakubowski, znający obcy język zaledwie od dziesięciu miesięcy. Praca Augusta Antoniego wyróżnia się znacząco na tle dotychczasowych publikacji. Syn Malczewskiego jako pierwszy przybliżył amerykańskiemu czytelnikowi tłumaczenia najbardziej reprezentatywnych utworów Mickiewicza, który był dla niego największym autorytetem literackim. Bowring w swoim Speciments of the Polish Poets z 1827 roku jedynie wspominał o obiecującym polskim poecie z Nowogródka. Jednak nie tylko pod tym względem dzieło młodego wygnańca jest zupełnie unikatowe. Dotychczasowe publikacje Szyrmy i Bowringa nie miały w sobie bowiem takiego ładunku emocjonalnego oraz osobistego zaangażowania. Żaden $\mathrm{z}$ nich nie wlał $\mathrm{w}$ pisane przez siebie słowa tyle uczucia, co Jakubowski. Rosienkiewicz miał rację, stwierdzając w Wiadomości biograficznej, że pisma Jakubowskiego "malują duszę jego"194. Dlatego też The Remembrances... to dzieło, bez którego nie można w pełni zrozumieć twórczości Jakubowskiego. Stanowi ono sumę wiedzy młodego autora nie tylko o literaturze, ale też o historii, szkolnictwie i Podolu. Książka ta jest prawdziwym świadectwem jego zainteresowań, lektur i przekonań, a wobec braku rękopisów Jakubowskiego stanowi ona jedyny osobisty głos poety o nim samym wśród przekazów osób trzecich. Przebija z niej szczera miłość do rodzinnego kraju i chęć przybliżenia go amerykańskiemu czytelnikowi w najważniejszych aspektach.

Dzieło Jakubowskiego nie było w zamierzeniu antologią, ale esejami uzupełnionymi wyjątkami z poezji przetłumaczonymi przez autora. Już sam tytuł Wspomnienia polskiego wygnańca dawał duże możliwości, nie zmuszając autora do trzymania się sztywnego naukowego wywodu. Podobną swobodę gwarantowało sięgnięcie po formę eseju. Pozwoliło to Jakubowskiemu w nieskrępowany sposób wyrazić swoją romantyczną indywidualność - swobodnie nawiązywał do wybranych utworów, cytatów i faktów. The Remembrances... stanowią integralną, dobrze przemyślaną całość, począwszy od tytułu do zamykających książkę odezw o charakterze politycznym, przechodząc tym samym od tonu osobistego do publicystycznego. Składają się one z następujących części:

19:3 E. Żuk, "The Remembrances of a Polish Exile” Augusta Antoniego Jakubowskiego, "Ruch Literacki" 1979, z. 5, s. 348.

14:1 M. Rosienkie wi c Z, Wiadomość biograficzna..., s. XII, s. 68. 
Dedication: To the ladies of America [Dedykacja: Do Dam Ameryki], podpisane "A. J. $\eta$

Introductory Remarks [Uwagi wstępne autorstwa W. B. Sprague'a]

Preface [Przedmowa]

Essay on Polish poetry [Esej o polskiej poezji]

The Primrose. An Imitation of Mickiewicz [Pierwiosnek, naśladowanie z Mickiewicza]

A Song of Podolia [Pieśn Podola (Gdyby ortem być) thumaczenie utworu Maurycego Gosławskiego]

A Girl. Song from Korsak [Dziewczyna, Pieśn Korsaka]

Song. From Mickiewicz's poem Ancestors [Pieśn. Z poematu Mickiewicza „Dziady”] Imitation of a Song from the poem Wallenrod [Naśladowanie pieśni z poematu "Konrad Wallenrod"]

Historical Sketch of Education in Poland [Historyczny szkic o edukacji w Polsce]

The Polish Lovers [Polscy kochankowie]

The Causes of the Emigration of the Poles [Przyczyny emigracji Polaków]

Address of the Polish Committee in Paris to the Polish Emigrants [Odezwa Komitetu Polskiego w Paryżu do polskich emigrantów]

Appendix containing a short notice of Ukraine and Podolia [Dodatek zawierajacy krótka wzmiankę o Ukrainie i Podolu]

The Insurrection [Powstanie, thumaczenie utworu Tymona Zaborowskiego] Song [Pieśń]

Czytając spis treści, nie sposób nie zauważyć bogactwa i różnorodności tematów, a także wieloperspektywicznego spojrzenia młodego autora na polską kulturę. Chociaż Julian Krzyżanowski zarzucał Jakubowskiemu „puste i gładkie ogólniki"195, to trzeba podkreślić, że syn Malczewskiego w The Remembrances... jawi się jako mistrz syntezy, gdyż wszystkie wspomniane rozdziały zmieścił na 70 stronach formatu $17 \times 10 \mathrm{~cm}$. Również sam tytuł dzieła został bardzo dobrze dobrany, gdyż nie tylko pozwala na swobodę gatunkową, ale przede wszystkim zaznacza dramatyczne okoliczności opuszczenia kraju. Gdyby Jakubowski użył słowa "emigrant", nie uzyskałby tak przejmującego efektu.

Pierwsze trzy części The Remembrances... wyznaczają krąg potencjalnych odbiorców. W pierwszej kolejności są to „damy Ameryki”, którym Jakubowski osobiście dedykuje swój tomik. Jak pisał Eugeniusz Żuk, decyzja ta narzuciła autorowi „pewne kryterium doboru materiału”196, stąd część utworów zdaje się być podyktowana chęcią trafienia w gust tamtejszych dam rozczytujących się w romansach. Prawie wszystkie przetłumaczone przez Augusta Antoniego teksty zawierają wątek miłosny albo pierwszoplanowe role odgrywają w nich kobiety.

Warto zaznaczyć, że powiastka prozatorska The Polish Lovers napisana przez Jakubowskiego również skupia się na ukazaniu miłości zarówno do kobiety, jak

195 J. Krzyża now ski, A. A. Jakubowski. Syn Malczewskiego, [w:] id e m, W świecie romantycznym, Kraków 1961, s. 256, Biblioteka Studiów Literackich.

${ }_{196}$ E. Żuk, The Remembrances..., s. 346. 
i do ojczyzny. Dedykacja natomiast ma postać krótkiego, ale nasyconego symbolami wiersza. Podmiot liryczny przyrównuje się w nim do "wędrownego ptaka", który $z$ dala od rodzinnego kraju ofiaruje swoje pieśni niczym kwiaty damom mieszkającym w miejscu jego tułaczki. Poeta zarysował tutaj ostry kontrast pomiędzy Południem, czyli ojczyzną skutą zimą i lodem (metafora zaborów), a pięknym, wiosennym niebem Północy (Ameryki).

Po tym osobistym tonie dedykacji, przełamującej dystans między odbiorcami, następują uwagi wstępne autorstwa Sprague'a. Są one bardziej oficjalne, ale nadal utrzymane w przyjaznej atmosferze. Pastor był osobą znaną i cenioną w Ameryce. Jego protekcja i uznanie stanowiły najlepszą nobilitację i rekomendację dla nieznanego nikomu zdolnego młodzieńca z Podola. Sprague w swoich kazaniach gorąco przekonywał rodaków do niesienia pomocy polskim zesłańcom, wskazywał na zasługi Kościuszki i Pułaskiego dla Ameryki, podkreślał, że to, co łączy ich dwa narody, to umiłowanie wolności. Również w swojej przedmowie zaznaczał:

Pamiętamy, że nasza wtasna narodowa wolność częściowo zawdzięczamy ofierze krwi synów Polski; podczas gdy pielęgnujemy w naszych sercach pamięć o tych, którzy za nas cierpieli, mamy wspólny obowiązek okazania wdzięczności temu krajowi; póki zatem oddychamy powietrzem wolności, nie przestaniemy wspótczuć jej klęskom i modlić się, aby panowanie jej prześladowców załamało się ${ }^{197}$.

Tekst Sprague’a stanowił świadectwo solidaryzowania się z Polakami, a także wiary i nadziei w odrodzenie ich ojczyzny. Na tym tle przedstawiał on historię polskich patriotów, którzy po klęsce powstania listopadowego zostali zesłani do Stanów Zjednoczonych, gdzie większość z nich, jego zdaniem, znalazła zatrudnienie i cichą przystań. Spośród 26 Polaków przybyłych do Albany pastor szczególną opieką otoczył Augusta Antoniego ze względu na jego nieprzeciętne zdolności. Dostrzegał w nim zadatki na genialnego twórcę, co podkreślił dwukrotnie, gdyż Jakubowski dokonał gigantycznej pracy, samodzielnie pisząc tak ambitne dzieło. Pastor podkreślił wartość poznawczą tej publikacji dla Amerykanów. Uważał, że większość zawartych tu faktów będzie dla nich nowością. Zaznaczał również, że Jakubowski należał do jednej z najświetniejszych polskich familii i odebrał staranne wykształcenie; stąd nie musiał jak większość rodaków wykonywać pracy fizycznej, ale mógł uczyć języka francuskiego w renomowanej szkole. Tekst Sprague’a dostarcza badaczowi ważnych wskazówek, pozwalających umiejscowić chronologicznie pewne fakty z życia autora Wspomnień... Swój wstęp opatrzył datą 30 stycznia 1835 roku, zaznaczając, że August Antoni zamierza właśnie wyjechać do swojego stryja w Meksyku, którego odnalazł. Przede wszystkim określił też

19: W oryginale: We remember that for our own national freedom we are partly indebted to the sacrifices and the blood of her sons; while we embalm in our hearts the memory of those who have suffered for us, we gladly recognize the common obligation of gratitude under which they have laid us to their country; and so long as we breathe the air of liberty, we will not cease to sympathize with her in her calamities, and to pray that the rod of her oppressors may be broken. A. A. J a k u b ow ski, The Remembrances..., s. 6. 
wiek Jakubowskiego na 19 lat, co również potwierdzałoby tezę, że syn Malczewskiego urodził się w 1816 roku. Źródło to wydaje się wiarygodne, gdyż August Antoni musiał mieć wgląd w edycję książki przed wydaniem, a poza tym pytanie: „ile masz lat?" wydaje się najbardziej naturalnym przy zawieraniu znajomości. Pastor potwierdził również to, że Jakubowski nie miał dostępu do naukowych źródeł, lecz czerpał z własnej pamięci przy pisaniu szkiców dotyczących polskiej literatury, historii i kultury, a także tłumacząc utwory romantyczne. Poza tym ze słów Sprague’a wyłania się obraz młodzieńca (young gentleman) niezwykle sympatycznego, który swoim urokiem zjednywał sobie wszystkich nowo poznanych ludzi: „jego niezmiennie grzeczne, rozważne i szlachetne maniery zapewniły mu wielką przyjaźń i szacunek wszystkich, którzy mieli przyjemność go poznać"198. W zbliżonym tonie wypowiadał się o nim Rosienkiewicz w Wiadomości biograficznej, Sobolewski w swojej antologii, a podobne wspomnienie pojawiło się także w nekrologu Jakubowskiego, opublikowanym w „Daily Hampshire Gazette”199.

Następująca później przedmowa Jakubowskiego jest powtórzeniem i zaakcentowaniem istoty oraz przesłania dedykacji. Florystyczne obrazowanie i metaforyka, charakterystyczne dla całej twórczości Jakubowskiego, posłużyło tu do retorycznego umniejszania wartości swojego dzieła (topiki skromności dzieła), co wyrażone zostało słowami:

Owe kwiaty polskie sạ ubogie i brak im koloru, jeśli jednak Damy Ameryki czasem na nie spojrza $i$ wspomna o ofiarodawcy, będzie to dla niego wystarczająca nagroda za ich zebranie ${ }^{200}$.

Zabieg ten niwelował dystans i sprawiał, że autor przestawał być obcym. Sprzyjało temu także odejście od naukowego wywodu na rzecz prostego przekazywania myśli i uczuć. Można odnieść wrażenie, że Jakubowskiemu zależało właśnie na zbudowaniu poczucia wspólnoty między losem Polaków i Amerykanów jako narodów miłujących wolność, co podkreślał także Sprague. August Antoni przedstawił siebie jako jednego z tułaczy, któremu za szybko odebrano nie tylko radość życia, ale jakąkolwiek nadzieję na przyszłość. Wspomnienia z jednej strony stanowią jedyny skarb, jaki pozostał mu po szczęśliwej przeszłości, ale stają się zarazem przekleństwem, traumą nie do zniesienia, o czym napisał Jakubowski: „Jednak kiedy tylko zacząłem wydobywać swą pamięć z popiołów, tyle się nagle pojawiło przede mną zjaw, że znowu pogrzebałem je w swojej piersi"201. Widma przeszło-

${ }_{19 K} \mathrm{~W}$ oryginale: and his uniformly amiable, discreet and gentlemanly deportment, has secured to him, in an unusual degree, the respect and friendship of all who have had the pleasure of his acquaintance. A. A. Jakub ow ski, The Remembrances..., s. 7.

199 Por. P. Sobolewski, op.cit., s. 458.

${ }^{200}$ W oryginale: These Polish flowers are poor and colourless; but if the ladies of America will sometimes look on them and think of the giver, he will be amply repaid for collecting them. A. A. J a k u bow ski, The Remembrances..., s. 10.

$201 \mathrm{~W}$ oryginale: But when I began to remove the ashes of my memory, so many spectres rose before me that I again buried them in my own breast. Ibidem, s. 9 . 
ści powracają bardzo często w wierszach Jakubowskiego, przepojonych metaforyką śmierci, melancholii i właśnie popiołu - w kilku z nich porównał serce do urny popiołów. Wygnaniec zatem pozostaje sam z niewysłowionym cierpieniem wspomnienia i nie mogąc przedstawić całej swojej historii, decyduje się opisać jej fragmenty.

Przedmowa jest przede wszystkim bardzo dojrzałym i świadomym zaprezentowaniem swojego dzieła zagranicznemu czytelnikowi. Warto zacytować dłuższy fragment, w którym syn Malczewskiego dokonuje autoprezentacji:

Jeżeli ktokolwiek zainteresowany jest losem owego wielkiego narodu, który kochat wolność tak bardzo, a teraz znajduje się w niewoli, który kiedyś jaśniat w chwale, a teraz nie istnieje, może zechce dowiedzieć się czegoś o jego oświacie, poezji i uczuciach. Jednak nie mając biblioteki, do której mógtbym sięgnać, a jedynie swoja wtasna pamięć, pisząc $w$ języku, który znam $w$ niewielkim stopniu $i$ wspierany tylko przez kilka osób, dzięki którym słowa te ukazuja się drukiem, uznałem, że niemożliwościa bytoby stworzenie kompletnego opisu tych spraw (...). Zamierzatem napisać historię, a spisatem jedynie jej ułamki ${ }^{202}$.

Skrótowość, dążenie do uogólnień i szkicowej syntezy, cechujące całe dzieło Jakubowskiego, stają się jego wielką zaletą. Każda część daje Amerykanom obraz tragicznego losu bohaterskiego narodu, który został zniewolony, choć wiele mógł jeszcze dokonać. W eseju o literaturze autor ukazał poetów wciąż piszących w ojczystym języku patriotyczne utwory, choć dławionych przez cenzurę, która nie pozwalała opublikować większości tych dzieł. W swoim szkicu o edukacji przybliżył zreformowany stan szkolnictwa, na którym rękę położył Nowosilcow nazwany „a cruel instrument in the hands of a dark despot of the North" [okrutnym narzędziem w rękach mrocznego tyrana Północy ${ }^{203}$. Natomiast $w$ tekście The Causes of the Emigration of Poland pokazal jego terror wobec filomackiej młodzieży i powstańców, kwiatu polskiej inteligencji i nadziei przyszłych pokoleń. Znamienne jest to, że między dwoma wspomnianymi rozdziałami Jakubowski umieścił napisaną przez siebie powiastkę The Polish Lovers jako pomost, który od ogólnie zarysowanej sytuacji politycznej w Polsce przechodzi do opisu dramatycznych losów jednostek.

Piotr Chmielowski twierdził, że Józef Korzeniowski już jako student marzył, aby dowieść światu, że „Polak po straceniu swego kraju nazwiska potrafi je wskrzeszać geniuszem"204. Udało się to jego uczniowi z Liceum Krzemienieckiego, Jakubowskiemu. Patrząc na amerykański etap twórczości poety, The Remembrances...

${ }^{202} \mathrm{~W}$ oryginale: If there are any who are interested in the fate of a great nation, which loved freedom so much and is now in bondage, which once celebrated exists now no more, they will be curious to know something of its education, its poetry, and its sentiments. Having no library to refer to, but my own memory, writing in a language but little known to me, and assisted by some persons, by whose care it is published, I have found it impossible to give a sufficient description of them. Ibidem.

${ }^{2013}$ Ibidem, s. 39.

214 P. Ch m i elow ski, Józef Korzeniowski, jego życie i dzialalność literacka, Petersburg 1898, s. 51, Życiorysy Slawnych Polaków, nr 3. 
stanowi jego opus magnum, które przypomniało o Polsce na innym kontynencie i rozsławiło imię autora aż do jego tragicznej śmierci. Znamienne są słowa Sprague'a, który napisał o Wspomnieniach polskiego wygnańca:

Nie mam też zadnych wątpliwości, że wszyscy, którzy przeczytaja to dzieło, zgodza się ze mną, że wskazuje ono geniusza, który osiagnawszy dojrzatość, mógtby opromienić swa chwata każdy kraj ${ }^{205}$.

\section{Such was and such is our poetry ${ }^{206}$, czyli esej o polskiej poezji}

Wydaje się, że Rosienkiewicz dobrze znał Jakubowskiego i przeniknął istotę jego twórczości, wybierając jako motto patronujące Pismom pośmiertnym cytat: „Miej serce i patrzaj w serce”. Czytając The Remembrances..., nie sposób oprzeć się wrażeniu, że tym właśnie kryterium posługiwał się Jakubowki. Utwory mają dla niego wartość, o ile są wyrazem szczerego uczucia, dlatego też najwyżej oceniał ze spuścizny Kochanowskiego właśnie jego Treny. Już w przedmowie zaznaczył, że Wspomnienia polskiego wygnańca dają wgląd nie tylko w ścisłą wiedzę, ale też w uczucia jego narodu. Jakubowski nie jawi się jako badacz i historyk polskiej literatury sensu stricto, ale poeta ratujący od zapomnienia dziedzictwo swojego narodu. Jego stanowisko ujawnia się wprost na samym początku eseju o polskiej poezji: „Mówiąc o polskiej poezji, nie tylko wspomnę o naszych pismach, ale i o naszych myślach, nie tylko o wierszach naszych, ale i uczuciach. Zaiste, gdzie mamy szukać poezji, jeśli nie w sercu?"207.

Proza Jakubowskiego przesycona jest poezją. W bardzo sugestywny sposób wyjaśniał on, jakie znaczenie dla Polaka ma słowo „ojczyzna”. Pisał, że na przekór „żelaznym rękom despotyzmu" (the iron hands of despotism) polski naród pielęgnował w sobie miłość do ojczyzny, aż stała się ona jego poezją, ideałem, po prostu wszystkim (his all) ${ }^{208}$. Autor podkreślał, że nie da się tego uczucia przyrównać do wspólnego innym krajom dążenia do politycznej niepodległości. Uważał, że polski patriotyzm przypomina starożytną gotowość poświęcenia życia dla rodzinnego kraju, parafrazując słynną sentencję Horacego: dulce est pro patria mori [słodko jest umierać dla ojczyzny]. Kraj rodzinny staje się personifikacją cnoty i jedynym możliwym szczęściem. Jakubowski zaznaczał, że to właśnie $\mathrm{z}$ tych gorących uczuć patriotycznych i z serca rodziła się polska poezja towarzysząca żołnierzom nie tylko w czasie walk o wolność, ale także w chwili śmierci:

205 W oryginale: and I can scarcely doubt that all who read it agree with me, that it indicates a genius which might in the progress of its development, shed glory on any country. A. A. J a ku b o w ski, The Remembrances..., s. 8.

206 Thumaczenie: Taka była i taka jest nasza poezja.

${ }^{2017} \mathrm{~W}$ oryginale: In speaking of the poetry of Poland, I shall not only mention our writings, but our thoughts; not only our verses, but our sentiments. And, indeed, where shall we look for poetry if not in the heart? Ibidem, s. 11.

Iow Ibidem. 
Poezja Polski jest jej prawowita córka, ponieważ posiada wszystkie właściwe jej cechy, melancholię i radość, waleczność i patriotyzm. Nieszczęścia naszego kraju, jego niewola razem $z$ największym pragnieniem wolności dato poetycki rys naszemu życiu, naszym myślom i uczuciom. Polak zawsze żyt pomiędzy nadzieja a wspomnieniem ${ }^{209}$.

Jakubowski, podobnie jak Lach Szyrma, nie wdawał się w szczegółowe omówienia twórczości prezentowanych pisarzy. W swoim eseju nie przedstawił publiczności ogólnego zarysu literatury polskiej czy nawet podziału na epoki, ale przybliżył kwestie najciekawsze dla amerykańskiego czytelnika. Sam podkreślił w przedmowie, że nie opisał historii, lecz jej fragmenty. O średniowieczu wspomniał jedynie w Historical Sketch of Eduation in Poland w podobnym tonie jak Bentkowski w swojej Historii literatury polskiej. Warto zaznaczyć, że według Mickiewicza brakowało w podręczniku Bentkowskiego „krytycznych postrzeżeń"210, czego nie można powiedzieć o The Remembrances...

Szyrma nazwał renesans „złotym wiekiem poezji polskiej” i wymienił pokrótce autorów, takich jak: Rej, Kochanowski, Klonowic i Szymonowic. Jakubowski ograniczył swój wywód do największego z nich - Jana z Czarnolasu. Uważał go za pierwszego poetę piszącego $w$ języku polskim i uznawał za niedościgniony wzór dla współczesnych czarnoleskiemu poecie pisarzy, nieudolnie próbujących go naśladować. Autor Trenów w oczach Jakubowskiego był jedynym godnym wspomnienia renesansowym twórcą, gdyż „zebrał pierwsze kwiaty polskiej poezji i złożył je na grobie ukochanej córki" ${ }^{211}$. Również Mickiewicz z oryginalnych pism Kochanowskiego najbardziej zachwycał się trenami, podkreślając, że „żadna literatura nie posiada nic podobnego"212. Fascynował się tkliwością i głębią przekazywanych w nich uczuć. Podobnie jak Jakubowski, zwracał uwagę na ich autentyczny charakter, bez cienia przesady i pozy. Syn Malczewskiego podkreślał, że ojciec Urszulki naśladował jedynie tony własnego serca (imitated tones of his heart) ${ }^{213}$. Widział w nim mistrza formy, genialnego rzemieślnika klasycystycznych wzorów, który stworzył models of versification [wzory wersyfikacyjne] ${ }^{214}$. Podobnie jak Bowring, Jakubowski podkreślał, że Kochanowski wygładził język polski (polished our language). Jednak nawet renesansowy twórca nie mógł u Augusta Antoniego znaleźć całkowitego uznania. Jakubowski najwyższą wartość upatrywał bowiem w orygi-

219 W oryginale: The poetry of Poland is her legitimate daughter. She has all her characteristics, melancholy and gay, warlike and patriotic. The misfortunes of our country, its bondage, together with the strongest desire for liberty, has given a poetic cast to our lives, our thoughts and feelings. $A$ Pole lived always between hope and remembrance. Ibidem.

${ }^{210}$ A. Mickiewicz, Dzieła. Proza artystyczna i pisma krytyczne, t. 5, Warszawa 1997, s. 170 .

211 W oryginale: Kochanowski gathered the first flowers of Polish poetry, and scattered them upon the tomb of his beloved daughter. A. A. J a ku b ow ski, The Remembrances..., s. 32.

${ }^{212}$ A. Mickie wicz, Literatura stowiańska. Wyklady w College de France. Kurs drugi, Warszawa 1935 , s. 376.

213 A. A. Ja kubow'ski, The Remembrances..., s. 33.

214 Ibidem, s. 32. 
nalności i kierowaniu się uczuciem. Dlatego dziewiętnastolatek surowo ocenił jego tłumaczenia Horacego oraz zależność od starożytnych wzorów.

Trzeba jednak zaznaczyć, że opinia młodego wygnańca nie tylko nie była odosobniona, ale przeważała $w$ obozie zwolenników romantyzmu. Od końca XVIII wieku rozwinął się bowiem w Polsce prawdziwy kult Jana z Czarnolasu, którego uważano wówczas za poetę najdoskonalszego i „najbardziej narodowego, arcypolskiego"215. Dlatego też klasycy (jak chociażby Morawski czy Dmochowski) stawiali swoim oponentom właśnie jego twórczość za „najwyższy i obowiązujący wzór poezji narodowej" ${ }^{216}$. $Z$ tego powodu romantycy podważali narodowy charakter dzieł czarnoleskiego poety, zarzucali mu zbytnią inspirację wzorami klasycznymi (głównie Horacym). Atakowano go za odrzucenie ludowej twórczości, co miało rzutować na rozwój polskiej literatury i wpędzić ją w zbytnią zależność od obczyzny. Bardzo ostro wystąpił przeciwko Kochanowskiemu Maurycy Mochnacki w Myślach o literaturze polskiej z 1828 roku, gdzie zarzucał renesansowemu twórcy brak pierwiastka "pierwotnego i narodowego"217 w jego utworach. W ogniu krytyki znalazły się nawet Treny, które wysoko cenił Korzeniowski, a za nim Jakubowski, wspominający ich autora dwukrotnie w The Remembrances...

Warto zauważyć, że dzieło Jakubowskiego w wielu miejscach odznacza się większą dojrzałością niż List do pana de Bonstetten Zygmunta Krasińskiego, który w chwili jego pisania w 1830 roku był prawie w wieku Augusta Antoniego. Oba teksty stworzono w obcym języku z myślą o zagranicznym czytelniku i są do siebie podobne w przedstawieniu zarysu historii Polski, jej poszczególnych etapów oraz przyczyn upadku. Wymieniają one również te same osoby na przestrzeni dziejów ojczystej literatury: Kochanowskiego, Szymanowskiego, Karpińskiego, Krasickiego, Trembeckiego, Naruszewicza, Niemcewicza, Felińskiego, Zaleskiego, a także Dmochowskiego jako tłumacza Illiady. Krasiński wspominał o silnej inspiracji wzorami francuskimi, ale nie potępiał tego zjawiska tak jak Jakubowski. Nie zagłębiał się również w takim stopniu jak August Antoni w omówienie dzieł Mickiewicza. Różnił się od niego także pewnymi sądami, na przykład wypowiadał się z wielkim uznaniem o kurateli nad szkolnictwem, sprawowanej przez cara Aleksandra $\mathrm{I}^{218}$, którego Jakubowski nazywał "mrocznym despotą Północy" i z odrazą pisał o jego działalności. Należy pamiętać, że młody Krasiński był nie tylko synem senatora Królestwa Polskiego i zwolennika podporządkowania Polski Rosji, ale tekst swój pisał przed powstaniem listopadowym i represjami z nim związanymi, jakich osobiście doświadczył Jakubowski.

Podczas gdy Mickiewicz zaznaczał w swoich wykładach, że: „Epoka Stanisława Augusta nie zajmie nas długo (...) jest ona mało słowiańska, nawet mało naro-

215 S. P i g o ń, Studia literackie, Kraków 1951, s. 36, Literatura, Sztuka, Krytyka, nr 16.

216 Ibidem.

217 M. Moch na cki, Rozprawy literackie, red. Z. St e f a n ow s ka, Wrocław 2004, s. 109.

21 Z. Krasiński, Dzieta literackie, t. 3, red. P. He rtz, Warszawa 1973, s. 228, Biblioteka Poezji i Prozy. 
dowa"219, Jakubowski poświęcił w swojej pracy sporo miejsca właśnie oświeceniu, stawiając je w opozycji do romantyzmu. XVIII wiek był dla niego czasem odnowy polskiego piśmiennictwa i edukacji, ale nie wiekiem poezji. Stefan Witwicki w bardzo zbliżonym tonie charakteryzował piśmiennictwo oświecenia, przyrównując je do sztucznego przepychu naprędce namalowanych kwiatów. Polski wygnaniec odwoływał się do podobnej metaforyki, również widział w literaturze tamtych czasów ogród kwitnący tylko bladymi i nienaturalnymi kwiatami francuskiej literatury. Witwicki twierdził, że całe pisarstwo stanisławowskie „nie miało w sobie nic szczerego (...) i nie szło z serca"220. Te same zarzuty wobec oświecenia podnosił Jakubowski. Młody poeta podsumował tę epokę w następujący sposób:

W tym czasie gustowano głównie w literaturze cudzoziemskiej, nasi poeci tłumaczyli $i$ naśladowali ja, ale pisali niewiele rzeczy oryginalnych. Preferowana byta szkoła francuska, kopiowano przede wszystkim Woltera i Rasyna ${ }^{221}$.

Na młodzieńcu wychowanym w Liceum Krzemienieckim na wzorach klasycystycznych największe wrażenie robił Krasicki. Podczas gdy Mickiewicz nazywał go w swoich wykładach „księciem poetów”, syn Malczewskiego widział w nim twórcę przewyższającego arcydzieła Horacego, doceniając piętnowanie narodowych przywar w jego utworach satyrycznych. Wśród nich wymienił te, które uważał za doskonałe: Żona modna, Pijaństwo i Gracz. Jednak pierwszeństwo przyznawał niepodzielnie Monachomachii, satyrze na system kształcenia w kolegiach zakonnych. Był przekonany, że ten poemat heroikomiczny miał największy wpływ na zmianę ówczesnego systemu edukacji.

Jakubowski, podobnie jak Stefan Witwicki, spośród pisarzy epoki stanisławowskiej wyróżnił Franciszka Karpińskiego. Witwicki uznawał wyższość tego poety nawet nad Krasickim i Naruszewiczem, uważając, że w przeciwieństwie do nich poszedł on drogą oryginalnej twórczości wypełnionej „duchem narodowym, duchem prawdziwie polskim"222. Również syn Malczewskiego zaznaczał, że chociaż pisarz nie posiada w swoim dorobku znakomitego dzieła przyćmiewającego inne, to jego poszczególne wiersze ciągle mają moc poruszania serca czytelnika, stąd nazywał go w swoim szkicu „czułym pisarzem idylli”. Autor wspominał w The Remembrances... tylko twórców oryginalnych. Także Mickiewicz docenił Karpińskiego z tego powodu. Uważał, że tworzone przez niego sielanki nie stanowiły epigońskiego naśladownictwa przebrzmiałych starożytnych wzorów, ale pokazywały "charakter i usposobienie współrodaków”, dlatego wieszcz nazwał go „poetą swojego wieku i narodu"223. Sentymentalna poezja Karpińskiego była bliska

219 A. Mickie wi c z, Literatura słowiańska. Wyklady..., s. 252.

221) S. Wit wi c ki, Wieczory Pielgrzyma. Rozmaitości moralne, literackie i polityczne, t. 1, Lipsk 1866, s. 57, Biblioteka Pisarzy Polskich, nr 38.

221 W oryginale: At this time a taste for foreign literature prevailed, and our poets translated and imitated, but wrote little original. The French school was preferred, Voltaire and Racine much copied, A. A. Jakub ow ski, The Remembrances..., s. 15.

222 S. Witwicki, op. cit., s. 53.

${ }^{223}$ A. Mickie w'ic z, Dzieła. Proza artystyczna i pisma krytyczne..., s. 165. 
Jakubowskiemu, jej ślady możemy odnaleźć zarówno w Majorze Aleksandrze, jak i w utworach lirycznych, gdzie przeważnie doświadczenie arkadii i bezgranicznego szczęścia należy do przeszłości i kontrastuje $\mathrm{z}$ rozpaczą teraźniejszości. Dla polskiego wygnańca najważniejszym zadaniem poety było wierne odmalowanie uczuć nie tylko osobistych, ale oddanie polskiego ducha i pielęgnowanych przez niego wartości.

Warto zaznaczyć, że Mickiewicz obok Karpińskiego wskazał jeszcze Niemcewicza jako poetę antycypującego późniejszą epokę. Syn Malczewskiego jako jedynego uhonorował autora Śpiewów historycznych mikrobiografią na kartach swego eseju. Nawet uwielbiany przez niego wieszcz nie doczekał się zarysu swojego życiorysu. Wynikało to z silnych i wciąż żywych związków Niemcewicza z Ameryką, gdzie Jakubowski wydawał The Remembrances... W najdłuższym przypisie swojej książki wyjaśnił:

Mówiąc o Niemcewiczu, nie moge powstrzymać się od zaprezentowania publicznie niewielkiego szkicu jego życiorysu, gdyż do tej pory byt on obywatelem amerykańskim. Wyksztatcony na dworze księcia Czartoryskiego, w kolebce tak wielu naszych patriotów, swoje późniejsze życie uczynit wzorem publicznej, jak również prywatnej cnoty. Przybyt do Ameryki i walczyt u boku Kościuszki za wolność ziemi Waszyngtona. Po powrocie do Polski zostat wybrany postem na Sejm z 1788 roku, gdzie wyróżniat się zdolnościami retorycznymi. Jednak obrona kraju wezwała go ponownie do wojska $i$ walcząc $z$ Kościuszka, zostat uwięziony wraz z nim. Po wyzwoleniu wrócit kolejny raz do Ameryki, gdzie ożenit się z panną L ----- i pozostat tam wiele lat. W czasach Napoleona znów udat się do Polski i poświęcit się nauce $i$ literaturze. Wkrótce zostat tam prezesem naukowego stowarzyszenia. Tworzyt $w$ kilku dziedzinach, ale jako historyk i pisarz cieszy się największym uznaniem. $W$ naszej rewolucji postrzegany byt jako uosobienie męstwa i patriotyzmu ${ }^{224}$.

Podobnie jak Mickiewicz, nie wdawał się w krytyczny rozbiór dzieł Niemcewicza, ale zaznaczał najważniejszą wartość, która kierowała jego twórczością: miłość do ojczyzny. Jakubowski podkreślał, że patriotyzm towarzyszył poecie od początku życia i był mu droższy nad szczęście rodzinne oraz spokojne, dostanie życie. Również wieszcz w XXI wykładzie zaznaczał: „był on przede wszystkim Polakiem i wyłącznie Polakiem, pisma jego były dlań narzędziem w walce $\mathrm{z}$ wrogami

221 W oryginale: In speaking of Niemcewicz, I cannot refrain from giving a slight sketch of his history, as he has since been an American citizen. Educated at the court of Prince Czartoryski, the cradle of so many of our patriots, his after life was a model of public and private virtue. He came to America and fought at the side of Kosciusko for the liberty of the land of Washington. Returning to Poland, he was elected deputy to the celebrated Diet of 1788, where he distinguished himself by his eloquence. But the defence of his country called him again to the army, and fighting with Kosciusko, he was imprisoned with him. After his liberation he returned again to America, where he married Miss L----, and remained many years. In Napoleon's time he returned again to Poland, and devoting himself to science and literature, he became President of a learned society there. He wrote in several departments, but as a historian and novelist, he enjoys the highest reputation. In our revolution he was looked upon as the personification of virtue and patriotism, A. A. J a k u b o w s ki, The Remembrances..., s. 14. 
Polski"225. Nie bez znaczenia musiał być również fakt, że ojciec Jakubowskiego skierował dedykację Marii właśnie „Do Jaśnie Wielmożnego Juliana Niemcewicza”. Malczewski wyrażał w niej uwielbienie dla „biegu czystego i użytecznego życia" oraz twórczości autora Powrotu posła. Także Jakubowski używał epitetu useful (pożyteczne), wspominając o dziełach Niemcewicza. Podobnie jak ojciec wskazywał też na ogromną popularność pisarza.

Mimo uznania dla osiągnięć najwybitniejszych przedstawicieli literatury oświecenia, August Antoni podkreślał, że nie umieli oni tworzyć poezji (podobnie Mochnacki odmawiał oświeceniowym literatom godności poetów, nazywając ich rymotwórcami). Jakubowski zaobserwował, że paradoksalnie w czasie wydawałoby się najmniej sprzyjającym dla rozwoju literatury, po utracie niepodległości w końcu narodziła się poezja narodowa, którą nazwał „the strongest poetry of feeling" (najsilniejsza poezja uczucia) ${ }^{226}$. Pisał o niej w ten sposób:

Ale w tym czasie, kiedy poezja stopniowo wzrastała, polityczna śmierć naszego kraju głęboka, mroczna posępnościa zasnuła umyst ludzi, którzy zaczęli tworzyć $w$ głębi swoich serc najsilniejsza poezję uczuć i stali się gotowi, aby wejść, świeży i jaśni, na wielkie pole narodowej literatury ${ }^{227}$.

$\mathrm{Na}$ tym gruncie, jego zdaniem, rozwinęły się główne gałęzie XIX-wiecznej poezji: szkoła ukraińska („songs of Podolia and Ukraina”), a także szkoła krakowska. Znamienne jest to, że młody wygnaniec dokonał tego rozróżnienia dwa lata przed Tyszyńskim, który w Amerykance w Polsce zawarł podobny, choć nieco poszerzony, podział w rozdziale $O$ szkotach poezji polskiej.

Szkoła ukraińska, najbliższa Jakubowskiemu, cechowała się smutkiem i melancholią. Nazywał ją „dzieckiem nieszczęśliwego i romantycznego kraju, często pustoszonego przez Turków i Tatarów, a ostatnio zniszczonego przez Rosjan"228. Zaznaczał, że szczątki tej poezji nadal istnieją dzięki współczesnym literatom, którym dała ona „podstawę cech narodowych" ${ }^{229}$ w ich twórczości. Syn Malczewskiego wyróżniał trzy główne tematy tych utworów. Pierwsze pisane były ku czci bohaterów, bitew oraz wielkich wydarzeń historycznych. Drugie charakteryzowały się przewagą pierwiastka fantastycznego i baśniowego, przypominając przy tym szkockie ballady. Natomiast trzecią, najliczniejszą grupę stanowiły teksty pozbawione sprecyzowanego tematu, pełne ekspresji uczuć, tonu serca, tak jak zamieszczona przez Jakubowskiego piosenka zaczynająca się od słów: Tell me, tell

${ }^{225}$ A. Mickie wi c z, Literatura stowiańska. Wyktady..., s. 354.

${ }^{226}$ A. A. Ja kubows ki, The Remembrances..., s. 16.

227 W oryginale: But in the mean time, as poetry gradually arose, the political death of our country cast a deep dark gloom over the minds of the people, and they already sang in the depths of their heart, the strongest poetry of feeling, and even prepared to enter fresh and bright into the great field of national literature. Ibidem, s. 15.

22* Ibidem, s. 16.

229 Ibidem. 
me, little tree... [Powiedz, powiedz, małe drzewko...], prawdopodobnie napisana przez niego samego. Do tej pory figurowała ona jako niezidentyfikowany utwór, przetłumaczony przez młodego wygnańca na język angielski. Jednak w wyniku wieloaspektowej interpretacji tekstu wydaje się uzasadnione postawienie hipotezy, że jest to autorski utwór poety, stylizowany folklorystycznie ${ }^{230}$. Nawiązuje on bowiem do cech podolskiej dumki i twórczo je przetwarza. Odchodzi od charakterystycznej dla ludowej poezji regularności i jednorodności formalnej oraz struktury zwrotkowej. Wiersz ten nie posiada również tytułu ani autora, które August Antoni konsekwentnie podawał w The Remembrances... Centralnym motywem utworu staje się gest siania ziarna przez dziewczynę, która pochowała swojego brata. Podobnej realizacji nie udało się odnaleźć w pochodzących z tego okresu zbiorach ludowych pieśni żeńskich. Poza tym Tell me, tell me, little tree... ma charakter intertekstualny i można odnaleźć $w$ nim nawiązania do cenionej przez Jakubowskiego Marii Malczewskiego, gdzie choć ziarno kiełkuje w mogile, nie staje się symbolem zmartwychwstania i odrodzenia życia:

Tam znajdzie zbroje dawne, co zardzate leża

I koście, co nie wiedzieć do kogo należa

Tam znajdzie petne ziarno $w$ rodzajnym popiele

Lub robactwo rozlegte $w$ świeżym jeszcze ciele;

Ale po polach btadzi nie wspartszy się na nic -

Jak rozpacz - bez przytutku - bez celu - bez granic ${ }^{231}$

Również Maria Żmigrodzka wskazywała na to, że „doniosłości motywu śmierci i pustki" w obrazie ukraińskiego stepu nie może przełamać nawet powyższa wzmianka o ziarnie, gdyż

wbrew pozorom nie jest to tak częsty motyw w ówczesnej poezji odrodzenia z popiołów. Nastapiło właśnie zdewaloryzowanie symbolicznego motywu - popiót bohaterów to gleba, na której wzrasta tylko roślinność stepowa. I nad niq równiez ciaży powszechne prawo zaglady ${ }^{232}$.

Nową hipotezę o stworzeniu przez Jakubowskiego wspomnianego utworu mogłoby podważyć jedynie odnalezienie ludowego oryginału lub wiersza współczesnego mu poety, którym mógł się zainspirować.

Natomiast na zasadzie kontrastu autor przedstawił główne założenia „szkoły krakowskiej", której utwory były dla niego znacznie weselsze. Zazwyczaj krótkie, reprezentujące jedną myśl przewodnią stały się improwizowanymi piosenkami dedykowanymi ukochanej. Poeta podkreślał ich ludową proweniencję, ale tak-

2.x) Za cenne obserwacje, ulatwiające mi sformulowanie tejże hipotezy odnośnie do charakteru i autorstwa wiersza, dziękuję prof. Boguslawowi Dopartowi.

231 Antoni Malczewski, jego żywot..., s. 35.

${ }^{2: 32}$ M. Ż migrodzka, Dwa oblicza wczesnego romantyzmu (Mickiewicz - Malczewski), „Pamiętnik Literacki" 1970, z. 1, s. 77. 
że patriotyzm każący w ukryciu opiewać heroiczne czyny ostatniego powstania. Jakubowski zaznaczał, że: „prawie każdy chłop żyjący na brzegach Wisły i Dniepru jest poetą i śpiewakiem"233, przyznając wielkie znaczenie „pieśni gminnej jako arce przymierza".

$\mathrm{Na}$ tle tak zarysowanej panoramy polskiego świata literackiego Jakubowski zaprezentował twórczość Adama Mickiewicza, dzięki któremu nareszcie urzeczywistniła się „poezja serca”. Uwaga Rosienkiewicza, że autor Dziadów był dla Jakubowskiego "prawdziwym bożyszczem", w pełni potwierdza się w The Remembrances... W poezjach młodego wygnańca można znaleźć ślady inspiracji twórczością wieszcza (szczególnie jego sonetami), jednak dopiero we Wspomnieniach... fascynacja ta i wręcz uwielbienie dla Mickiewicza zostało wypowiedziane bezpośrednio: „błyszczy niczym samotna gwiazda wśród mentalnego chaosu myśli i uczuć (...). Wydaje się, jakby stworzył on nowy język, język duszy"234.

Podczas gdy Goszczyński w 1835 roku na łamach „Powszechnego Pamiętnika Nauk i Umiejętności" krytykował Mickiewicza za naśladownictwo, Jakubowski, którego tak mierził epigonizm u innych pisarzy, w stosunku do swojego mistrza zamienił ten zarzut $\mathrm{w}$ atut, podkreślając:

jego tematami byty wspomnienia naszej dawnej chwaty - kości naszych bohaterów błagaty go o pieśń, domagaty się od niego pieśni. Mickiewicz byt wykarmiony niemiecka, angielska $i$ wtoska literatura oraz rzymskimi i greckimi arcydzietami, co $w$ potaczeniu z jego wielka wiedza $i$ wrodzonym geniuszem sprawiło, że wyznaczyt sobie wspaniata drogę na polu literatury ${ }^{235}$.

Z tych słów poeta uczynił wstęp do omówienia Dziadów, nazwanych przez niego The Ancestors, opisując w nim raczej emocje towarzyszące lekturze zamiast bardziej konkretnych informacji. Podkreślał jednak przełomowy charakter tego dzieła, mimo że nie zostało ono ukończone. Enigmatycznie wspominał o zarysowanej w utworze namiętnej i szalonej miłości, silniejszej niż śmierć, oraz o powracającym zza grobu kochanku, opowiadającym swoją historię. Jakubowski po II części Dziadów zaprezentował Sonety krymskie, następnie Konrada Wallenroda, a na samym końcu III część Dziadów. Natomiast rozdział The causes of the emigration of Poles został zamknięty dokładnym tłumaczeniem pierwszych kilku wersów Ksiąg pielgrzymstwa polskiego, a także VII części Ksiąg narodu.

Jakubowski nie poświęcił wiele miejsca omówieniu Sonnets of Crymee, jakby podpisując się pod słowami Morawskiego, skierowanymi do Koźmiana-syna:

233 A. A. Jakubowski, The Remembrances..., s. 17.

2:31 W oryginale: He stands forth a single star on the mental chaos of thoughts and sentiments (...) It seems as if he had created a new language, the language of the soul. Ibidem, s. 18.

2:35 W oryginale: His materials were the remembrances of our ancient glory, the bones of our heroes cried to him for a song. Mickiewicz had been nourished by the German, English, and Italian literature, and by the Roman and Greek masterpieces; thus, joined to his great knowledge and his natural genius, he struck out for himself a brilliant path in the field of literature. Ibidem. 
Niech [...] twój ojciec nie żąda ode mnie, abym mu ttumaczyt, rozkładat piękności sonetów. Nigdy tego nie uczynię, bo poezja nie jest stworzona do operacji anatomicznych. Chce ona, jak mitość i religia, sądzona być samym czuciem ${ }^{236}$.

Podobnie Jakubowski oceniał utwory wieszcza przez pryzmat zawartych w nich uczuć. Zwrócił uwagę na inspirację stylem Petrarki, a także włączenie do cyklu tłumaczeń liryków włoskiego mistrza. Jednak w przeciwieństwie do Mochanckiego nie pisał wyraźnie o wyższości słowiańskiego poety nad Petrarką, który dla autora Myśli o literaturze miał być „sztuczny i konwencjonalny”237. Amerykańskiemu czytelnikowi postanowił też przybliżyć fragment Farysa (Faris). Przełożył od piętnastego wersu dwa dystychy utworu, które połączył z zakończeniem kasydy, opiewającej zwycięstwo bohatera mimo piętrzących się przeszkód. Była ona jednocześnie afirmacją potęgi jednostki i eskalacją frenezji romantycznej, przypominającą Wielką Improwizację. Jakubowski wzbogacił swoje tłumaczenie, wiernie parafrazując część szóstej strofy utworu (od wersów 34-37) - tym razem w prozie, uwydatniając osamotnienie Beduina i niebezpieczeństwo jego wyprawy:

Gdy czytamy [to dzieło], podązamy za jego Farysem tam, gdzie ani zielonowtose palmy, ani białe piersi namiotów nie ocieniaja jego skroni, gdzie tylko niebo mu baldachimem, gdzie gwiazdy tylko się poruszaja, gdzie skaty tylko spoczywajq̨ ${ }^{238}$.

Autor w obszernym przypisie wytłumaczył także znaczenie słowa „Faris”, porównując go do rycerza w europejskiej literaturze. Wyjaśnił również, że utwór ten był dedykowany Wacławowi Rzewuskiemu, co stanowiło pretekst do zaprezentowania jego niezwykłego życia. August Antoni przybliżył postać bogatego magnata kresowego, który przebywał na Bliskim Wschodzie, gdzie wsławił się w „beduińskich walkach” i uzyskał godność Emira. Później w arabskim stroju powrócił do ojczyzny, w której kultywował wybrane wschodnie zwyczaje. Nie bez znaczenia dla Jakubowskiego musiał być fakt, że Rzewuski osiadł na jego rodzinnym Podolu. Twórca The Remembrances... zaznaczył, że właśnie w tym regionie Emir był dowódcą oddziału w czasie powstania listopadowego. Przypomniał także o jego świetnym dorobku poetyckim („napisał kilka najwspanialszych utworów poetyckich"239) i ubolewał, że dotychczas nie został on opublikowany. Bardzo prawdopodobne, że Jakubowski zetknął się w 1829 roku z anonimową notatką oraz pogłoskami o planach pierwszego tłumaczenia Marii właśnie przez Wacława Rzewuskiego.

Natomiast w III części Dziadów dostrzegał Jakubowski poza mistrzostwem poetyckim także inne wartości: „więcej dostrzegamy w nim rozumu niż kwiatów

${ }^{2.36}$ S. Kaw y n, Mickiewicz w oczach swoich wspótczesnych, Kraków 1967, s. 160.

237 M. Mochnacki, op. cit., s. 76.

${ }^{23 *}$ W oryginale: While reading it we follow his Faris "where neither the green haired palms, nor the white breasted tents shade his brow, where the skies are his only canopy, where the stars only move and the rocks only rest. A. A. J a ku b o w s ki, The Remembrances..., s. 20.

${ }^{239}$ W oryginale: [he] wrote some pieces of the most brilliant poetry. Ibidem, s. 19. 
[uczuć], więcej z filozofa niż z poety" ${ }^{240}$. Eugeniusz Żuk podejrzewał, że August Antoni mógł mieć na myśli mesjanizm ${ }^{241}$. Dzieło to dedykowane „spółwięźniom, spółwygnańcom za miłość ku ojczyźnie prześladowanym"242 musiało być bliskie Jakubowskiemu, ponieważ odwoływało się do niedawnych, wciąż żywych doświadczeń młodego skazańca, który osobiście zetknął się z przemocą zaborców i stał się ich ofiarą. Poema stanowiły, według Jakubowskiego, „przerażający pomnik prześladowań" niewinnej młodzieży. Nie tylko w eseju o poezji wspominał o tyranii cara Mikołaja. Temat ten rozwinął również w szkicu o edukacji, gdzie opisywał represje (cruel persecution) członków stowarzyszenia Filaretów i Filomatów:

kilku z nich prawie na śmierć pobito, inni, ledwie dzieci, zostali wyrwani z ramion rodzin $i$ zakuci w kajdany albo wysłani, by wytrenować ich na rosyjskich zotnierzy. Chociaz Zan pragnąt poświęcić się za swoich towarzyszy, zostat $z$ wieloma $z$ nich zesłany na Syberię. Więcej niż stu młodych uczniów, także dzieci najpierwszych rodzin, było w ten sposób prześladowanych za kilka wolnościowych myśli ${ }^{243}$.

Słowa te mogły być echem lektury III części Dziadów, jak podejrzewał Krzyżanowski, albo też - jak sugerował Eugeniusz Żuk - śladem represji doznanych przez "Ateny wołyńskie” i Uniwersytet Wileński, któremu szkoła ta była podporządkowana ${ }^{244}$. Liceum Krzemienieckie znajdowało się pod „urzędową opieką" znienawidzonego senatora Nowosilcowa, nazwanego przez Jakubowskiego „okrutnym narzędziem w rękach mrocznego despoty Północy"245.

Także nie bez przyczyny syn Malczewskiego przebywający na wygnaniu zacytował w innym miejscu eseju słowa zamykające przedmowę Mickiewicza do III części Dziadów, skierowane przeciw obojętności sąsiednich narodów:

Nie piszę po to, aby wzbudzać litość $i$ wspótczucie dla mego kraju; możemy powiedzieć innym krajom Europy tak jak Chrystus: "Córki Jerozolimskie, nie płaczcie nade mna, ale placzcie nad sobq i nad swoimi dziećmi"246.

24I W oryginale: more of reason than of flowers, more of the philosopher than of poet. Ibidem, s. 21 .

211 E. Żuk, op. cit., s. 353.

$2 \cdot 2$ A. Mi c k i e w i c z, Dziady część III, [w:] i de m, Utwory dramatyczne, red. S. Pig oń, tlum. A. Górski, Warszawa 1982, s. 120.

${ }^{243} \mathrm{~W}$ oryginale: Several of them were nearly killed by beating; others, though mere children, were torn from the arms of their families and put in chains, or sent off to be trained as Russian soldiers. Although Zan wished to sacrifice himself for his comrades, he was transported with numbers of them to Siberia: more than one hundred of the young students, some children of the first families, were thus persecuted for a few liberal thoughts. A. A. J a k u b ow s ki, The Remembrances..., s. 41.

244 E. Żu k, op. cit., s. 354.

24.5 W oryginale: a cruel instrument in the hands of dark despot of the North. A. A. J a ku b ow ski, The Remembrances..., s. 40.

246 W oryginale: I write not to excite compassion or sympathy for my country; we can say to other countries of Europe as Christ has said: „Daughters of Jerusalem, weep not for me, but weep for yourselves and for your children". Ibidem, s. 21. 
Właśnie tym mocnym akcentem podsumował część eseju poświęconą poezji romantycznej, podkreślając, że wciąż żyje ona mimo politycznej śmierci kraju: „Taka była i taka jest nasza romantyczna i patriotyczna poezja"247.

Natomiast za najbardziej znaczące dzieło wieszcza Jakubowski uważał Konrada Wallenroda ${ }^{248}$, wpisując się tym samym w jego insurekcyjną lekturę. W rozdziale poświęconym edukacji syn Malczewskiego zauważał, że podczas gdy Lelewel zaszczepił w każdej młodej piersi pragnienie rewolucji, to właśnie Mickiewicz za sprawą tego utworu nadał mu poetycki kierunek. Nazywał go alegorycznym poematem, niezrozumiałym dla Rosjan, którzy pozwolili na jego publikację. Jakubowski podkreślał, że Wallenrod miał tak wielki wpływ na jego pokolenie, że można go uznać za jedną z głównych przyczyn wybuchu powstania listopadowego. Dlatego też w swojej miniaturowej antologii zamieścił właśnie poetycką parafrazę 11 zwrotki Pieśni Wajdeloty, cechującej się tyrtejskim charakterem:

If I could stir up the enthusiasm in the breast of my countrymen, if I could reallume the pale features of the dead, if I could speak burning words to the hearts of my brothers, perhaps they would live for a moment as sublimely as their ancestors lived always ${ }^{249}$.

Oprócz niej poeta przetłumaczył wiernie całą pieśń Halbana o Wiliji, zachowując ten sam układ wersyfikacyjny (podział na sześć strof, z których każda liczy cztery wersy). Prawdopodobnie dlatego, że autor nie przybliżył wcześniej szczegółowo losów Alfa oraz Aldony i nie chciał wprowadzać nowego, niejasnego dla czytelnika wątku, zmienił ostatni wers utworu, usuwając z niego okolicznik miejsca: w wieży

Jakubowski, dokonując apoteozy poematu Mickiewicza w 1835 roku, nie mógł wiedzieć, że po kilku latach sam autor będzie krytycznie oceniał Konrada Wallenroda. Mickiewicz nazywał go "dość ważną broszurą w sprawach bieżących” w czasach, kiedy został wydany, później natomiast nie nadawał mu „wyższej wartości"250 i był przeciwny tłumaczeniu go na język niemiecki ${ }^{251}$. Jak pisał Eugeniusz Żuk, większość pokolenia Augusta Antoniego:

247 W oryginale: Such was and such is our romantic and patriotic poetry. Ibidem, s. 21 .

214 W oryginale: the most considerable work of Mickiewicz is Wallenrod. Ibidem, s. 20.

219 Gdybym był zdolny wlasne ognie przelać

W piersi sluchaczów i wskrzesić postaci

Zmarłej przeszlości; gdybym umiał strzelać

Brzmiącymi słowy do serca spólbraci:

Może by jeszcze w tej jedynej chwili,

Kiedy ich piosnka ojczysta poruszy,

Uczuli w sobie dawne serca bicie,

Uczuli w sobie dawną wielkość duszy

I chwilę jedną tak górnie przeżyli,

Jak ich przodkowie niegdyś cale życie.

A. M i cki e wi c z, Konrad Wallenrod, Gdańsk 2000, s. 27.

2:x) Relacja Edwarda Chłopickiego, por. J. Brzozowski, Odczytywanie romantyków (2), Poznań 2011 , s. 13.

251 List Józefa Bohdana Zaleskiego do Ludwika Nabielaka z 4 grudnia 1832 roku. 
aprobowała już w pełni metody walki wybrane przez Wallenroda. Co więcej, w roku 1833 oddziały partyzanckie Zemsty Ludu, dowodzone przez Józefa Zaliwskiego, nie cofaly się przed żadnym niemal środkiem; zamachy, użcie trucizny, niszczenie mienia rzadu monarchicznego, dezorganizacja administracji carskiej - wszystko to znalazło się $w$ bogatym arsenale ich broni ${ }^{252}$.

Antoni Kozieradzki, uczący się w Liceum Krzemienieckim w tym samym czasie co Jakubowski, potwierdzał w pamiętniku fascynacje lekturowe swojego pokolenia, których odbicie można znaleźć również w twórczości polskiego wygnańca: „Nad wszystko najbardziej uwielbiano Wallenroda, Grażynę i wszystko co Mickiewiczowskie, a zatem i Zaleskiego Bohdana, i Marię Malczewskiego"253. Właśnie tego ostatniego obok wieszcza wymienił Jakubowski wśród najświetniejszych poetów epoki. Widział w swoim ojcu jedynego artystę, którego twórczość mogłaby rywalizować z utworami Mickiewicza, choć nie wspomniał o łączącym ich bliskim pokrewieństwie. Warto zaznaczyć, że w pierwszej redakcji Wiadomości biograficznej, zredagowanej 8 czerwca 1838 roku w liście Marcina Rosienkiewicza do Eustachego Januszkiewicza, została odwrócona znana z Pism pośmiertnych hierarchia wzorów, jakimi miał inspirować się młody poeta: Malczewski został wymieniony na pierwszym miejscu przed Mickiewiczem. Zachwyt Maria nie jest subiektywnym sądem młodego poety, bezkrytycznie zapatrzonego w ojca. August Antoni dorastał w czasach „rehabilitacji” dzieła Malczewskiego i uznania go za arcydzieło. Michał Grabowski podkreślał wówczas, że „gdybyśmy tylko mieli Marię i Grażynę, mielibyśmy już oryginalną literaturę"254, co potwierdził również Mochnacki w tekście O literaturze polskiej w wieku XIX ${ }^{255}$. Popularność dzieła Malczewskiego stała się tak wielka, że brakowało egzemplarzy dla chcących je przeczytać, wśród których byli: Witwicki, Nabielak, a nawet Mickiewicz. Pod koniec lat 20. zaczęły się również ukazywać dzieła silnie inspirowane Marią. Wśród nich Dymitr i Maria, dramat z 1829 roku autorstwa Józefa Korzeniowskiego, bardzo cenionego przez Jakubowskiego nauczyciela z Liceum Krzemienieckiego. Malczewski był przyjacielem autora Kursu poezji jeszcze w czasach szkolnych. Dwa lata później Juliusz Słowacki wydał Jana Bieleckiego, także powstałego pod wyraźnym wpływem Marii. Jakubowski opuścił kraj, kiedy zaczęto tłumaczyć poemat jego ojca na inne języki: niemiecki i angielski. Nie wiadomo, czy przebywając w 1837 roku w Ameryce, wiedział o ukazaniu się Marii w edycji Augusta Bielowskiego. Jakubowski przetłumaczył dwa fragmenty poematu swojego ojca. O dłuższym, opisującym Marię, którą zawłaszcza śmierć, będzie jeszcze mowa w rozdziale o Majorze Aleksandrze. Ciekawe jest to, że o ile pierwszy z nich pozostaje wierną translacją dzieła Malczewskiego, to drugi został poetycko przetworzony przez Augusta Antoniego i odbiega od dosłownego znaczenia oryginału.

252 E. Żu k, op. cit., s. 354.

25.3 A. Ko z i e r a d k i, Wspomnienia z lat szkolnych 1320-1831, Wrocław 1962, s. 160.

2:4 M. Mochnacki, op. cit., s. 312.

25.5 Ibidem, s. 157. 
Jakubowski przybliżył w nim opis dawnych obyczajów (description of the ancient manners) zawarty w piątej strofie pierwszej pieśni przedstawiającej ucztę $\mathbf{u}$ Wojewody, który pod pozorem zgody planuje zbrodnię. Początkowe pięć wersów jest bardzo podobnych w obrazowaniu radosnej atmosfery towarzyszącej przyjęciu, jednak kolejne wprowadzają niepokojący i złowrogi nastrój, tak charakterystyczny dla całego utworu Malczewskiego, ale nie występujący w tłumaczonej przez Jakubowskiego zwrotce. Podczas gdy u autora Marii przodkowie Wojewody uwiecznieni na portretach nie wzbudzają większej grozy, u Jakubowskiego wyraźnie kontrastują $\mathrm{z}$ biesiadującymi. Wrażenie potęguje przyrównanie płynącego węgrzyna do krwi, co może stanowić prefigurację przyszłych wydarzeń, zabieg często stosowany w poemacie ojca. Jakubowski uważał Marię za wieczny pomnik chwały Malczewskiego, który zapewnił mu zaszczytne miejsce na polskim Parnasie. Ubolewał jednak, że nie zajmował się on literaturą na poważnie, a tworzenie wierszy traktował jako rozrywkę. W rozdziale biograficznym została przedstawiona hipoteza sugerująca, że takie przeświadczenie o charakterze twórczości ojca mogła wpoić Augustowi Antoniemu matka, która tak właśnie zapamiętała młodego Malczewskiego.

Zbliżając się do końca eseju, Jakubowski czuł się w obowiązku wspomnieć także o mało znanych, ale wyróżniających się, jego zdaniem, dwóch poetach współczesnych Mickiewiczowi: Bohdana Zaleskiego i Seweryna Goszczyńskiego. Warto zaznaczyć, że nie tylko należeli oni do tzw. „szkoły ukraińskiej”, ale byli również zaangażowani $w$ działalność polityczną. Na pierwszym miejscu Jakubowski wymienił Bohdana Zaleskiego, którego podziwiał za to, że sięgnął do utworów folkloru ukraińskiego, dając im drugie życie. Podkreślał w niezwykle poetycki sposób, że dzięki niemu prawie zapomniane pieśni stały się „świeże jak ukraińskie zioła, żywe jak pędzące fale Dniepru"256. Mimo niewielu utworów opublikowanych przez Zaleskiego Jakubowski zaznaczał widoczne w nich „przebłyski geniuszu". Bardzo prawdopodobny wydaje się fakt, że autor tomiku wiedział o tym, że Zaleski był jednym z pierwszych wielbicieli twórczości Malczewskiego, którego poznał w Warszawie na krótko przed jego śmiercią, co uwiecznił po latach $w$ wierszu pt. Malczewski $w$ Warszawie. Z korespondencji pomiędzy Zaleskim a Grabowskim, wydanej przez Nehringa, przebija szczery żal, że zarówno Maria, jak i Sonety krymskie nie zostały należycie przyjęte przez krytykę.

Z uznaniem wypowiadał się Jakubowski także o Sewerynie Goszczyńskim. Podkreślał, że był on jednym z pierwszych, którzy rozpoczęli powstanie listopadowe ( $w$ nocy 29 listopada osobiście brał udział $w$ ataku na Belweder). Syn Malczewskiego cenił przede wszystkim jego patriotycznego ducha, pozwalającego mu stworzyć w czasie rewolucji wysokiej miary utwory. Wspominał także poemat Goszczyńskiego Castle of Kaniow, który w oczach Augusta Antoniego podniósł twórczość jego autora do najwyższego stopnia. W dorobku poetyckim

256 W oryginale: Fresh as the herbs of Ukraine, and wild as the rushing of Dnieper, A. A. J a k u b ow ski, The Remembrances..., s. 24. 
Jakubowskiego widać zarówno inspirację utworami powstańczymi Goszczyńskiego, pełnymi entuzjazmu patriotycznego, ale również jego skrajnie buntowniczymi lirykami humańskimi, jak też szczególną odmianą sentymentalizmu Zaleskiego.

Jakubowski zapewniał, że poza wymienionymi twórcami istnieje jeszcze duża grupa poetów „wielkiej nadziei”, ale ze względu na ograniczone ramy krótkiego eseju nie może o nich opowiedzieć. Znalazł jednak miejsce na dygresję poświęconą polskiemu dramatowi, choć w pierwszym zdaniu zaznaczył, iż jest on yet in a low state [jeszcze na niskim poziomie] ${ }^{257}$. Rozważania młodzieńca w tej materii pokazują, że Mickiewicz był dla niego autorytetem nie tylko jako poeta, ale również recenzent. Powoływał się na jego poglądy krytyczne (as Mickiewicz well observs [tak jak Mickiewicz słusznie zauważył] ${ }^{258}$ ), zawarte w ówczesnych publikacjach wieszcza. Podobnie jak w rozprawie Sztuka dramatyczna w Polsce Jakubowski podkreślał, że początki polskiego dramatu giną w „mrokach ciemnych wieków", a pierwszym wielkim twórcą w tej dziedzinie stał się Jan Kochanowski. Młody wygnaniec tak jak Mickiewicz wskazywał, że niestety starożytni klasycy byli przez polskich twórców bardziej cenieni, co nie pozwoliło stworzyć nam szkoły na miarę Szekspira w Anglii ani Calderóna czy Lope de Vegi w Hiszpanii $^{259}$. Kolejne fragmenty również brzmią niczym parafraza Mickiewiczowskiego artykułu, gdzie nie tylko powracają te same myśli, ale nawet identyczne sformułowania. August Antoni pisał na przykład: „W czasie odrodzenia piśmiennictwa odczuwano potrzebę narodowego teatru, niestety jednak był to wiek naśladowania"260, podczas gdy autor Grażyny konstatował: „W epoce odrodzenia piśmiennictwa i smaku pojawiły się na nowo sztuki narodowe", po czym stwierdzał przewagę wzorów francuskich ${ }^{261}$.

Syn Malczewskiego bardzo wysoko cenił utwory Franciszka Zabłockiego, uważał go za wyróżniającego się dramatopisarza wcześniejszej epoki. Wspominał również o Alojzym Felińskim jako autorze Barbary Radziwiłłówny, jednak miał do niej pewne zastrzeżenia:

To wielka i dobrze odmalowana galeria historyczna, jednak nie można jej nazwać tragedia. Nie posiada bowiem ani scen tragicznych, ani tragicznych uczuć. Wynika to z tego, ze Feliński i inni pisarze przed Mickiewiczem czcili wręcz bałwochwalczo reguty teatru francuskiego ${ }^{262}$.

25. Ibidem, s. 21.

${ }^{25 k}$ Ibidem, s. 22.

259 A. Mi ckie wi c z, Dzieta. Proza artystyczna..., s. 265.

26) W oryginale: On the time of the regeneration of letters, the want of a national theatre was felt, but unhappily it was an age of imitation, A. A. J a ku b ow ski, The Remembrances..., s. 22.

${ }^{261}$ A. Mickie wi c z, Dziela. Proza artystyczna..., s. 266.

${ }^{262} \mathrm{~W}$ oryginale: It is a large historic gallery well painted, but it could not be called a tragedy. It has no tragical scenes, nor tragical sentiments. For Felinski and other writers, before Mickiewicz, worshipped to idolatry the rules of the French theatre, A. A. Ja kub o w ski, The Remembrances..., s. 22. 
W powyższym fragmencie Jakubowski tylko pośrednio wspomniał o Mickiewiczu jako dramatopisarzu, najwyższe miejsce przyznawał swojemu nauczycielowi z Liceum Krzemienieckiego - Józefowi Korzeniowskiemu, który jego zdaniem zapoczątkował „nową erę” polskiej tragedii i „obudził śpiącą Melpomenę"263. Podkreślał, że jako dramaturg wzorował się on na Szekspirze ${ }^{26+}$ i zerwał z zasadą trzech jedności. Warto zaznaczyć, że jego przesadnie entuzjastyczna ocena twórczości Korzeniowskiego nie była wówczas odosobniona. Jeszcze zanim został zesłany do Ameryki, Jakubowski mógł czytać „Tygodnik Petersburski” z 1833 roku, a w nim recenzję Anieli, gdzie napisano, że jest ona „pierwszą tragedią w naszym języku, która swego tytułu nie zawiodła"265. Ten właśnie utwór o nieszczęśliwie zakochanej córce lekarza wymieniał Jakubowski jako pierwsze dzieło swojego nauczyciela. Zaznaczał, że chociaż pokazuje ono głównie życie domowe, a nie doniosłe historyczne zdarzenia, można w nim dostrzec zarodki geniuszu (embryo of a superior genius). Dodawał, że inne dramaty Korzeniowskiego, posiadające większe znaczenie, znajdują się jeszcze $w$ rękopisach i nie zostały wydane przez rosyjską cenzurę. Stefan Kawyn pisał o Korzeniowskim jako o „amatorze piękności romantycznych", ale zarazem "lękliwym i ostrożnym"266 uczniu Alojzego Osińskiego. Jednak to on jako nauczyciel musiał być jedną z osób, która przelała swój zachwyt nad poezją romantyczną na przyszłego autora The Remembraces... Antoni Kozieradzki, mogący być szkolnym kolegą Jakubowskiego, pisał:

Korzeniowski zaś byt stronnikiem szkoły romantycznej, unosit się nad niektórymi genialnymi jej utworami i swój zapat wlewat w uczniów. Lecz nie byt parcjalnym catkowicie, bo szanowat literature starożytna i ze czcia o niej wspominat stowem i uczniom przekazywat dla autorów starożytnych ten szacunek, jaki się należy starcom poważnym, stawnym i znakomitym ${ }^{267}$.

Jakubowski swój rozdział zamykał słowami, które, jakby powiedział Rosienkiewicz, „malują duszę jego"268, ponieważ są one wyrazem wielkiej miłości do ojczyzny, a także przekonania, że Polska wciąż żyje oraz głębokiej wiary w jej odrodzenie. Syn Malczewskiego musiał wiedzieć o politycznym znaczeniu The Remembrances..., stąd dumne i stanowcze przesłanie książki na przekór zaborcom, aby dać świadectwo Amerykanom, jakim narodem w rzeczywistości są Polacy i przedstawić ich prawdziwą historię. Brzmi ono następująco:

(...) nasza ojczyzna nie może zginać. Tyle chwaty spoczywa wokót jej imienia; taki duch poświęcenia żyje w niej; jej język wzbogacony poezja i pieśnia - to wszystko

263 Ibidem, s. 23.

2m Naśladownictwo Szekspira bylo przedmiotem zarzutów Goszczyńskiego, który mimo wszystko nazywal Korzeniowskiego najbardziej utalentowanym współczesnym polskim dramaturgiem, por. Nowa epoka poezji polskiej, [w:] Podróże i rozprawy literackie. Dzieła zbiorowe Seweryna Goszczyńskiego, t. 3, red. Z. Wa sile w sk i, Lwów 1910, s. 220.

26.5 E. Żuk, op. cit., s. 352.

26h S. Ka w y n, Mickiewicz w oczach swoich wspótczesnych, Kraków 1967, s. 157.

${ }^{267}$ A. Kozieradzki,op. cit., s. 160.

${ }^{268}$ M. Rosienkiewicz, Wiadomość biograficzna..., s. 68. 
mówi nam, że będzie ona jeszcze istnieć. Możemy jedynie żywić nadzieję, że pieśni te pomoga w przebudzeniu $i$ w przyszłym dniu ustyszymy dźwięk jej zemsty i zbawienia. Niech tak się stanie ${ }^{269}$.

Po tych uwagach Jakubowski postanowił załączyć jeszcze kilka fragmentów „naszej poezji". Wśród nich znalazły się Primrose (Pierwiosnek) Mickiewicza, Song of Podolia (Gdyby orłem być) Maurycego Gosławskiego, Girl (Dziewczyna) Juliana Korsaka, wileńskiego filarety, a także krótki wyjątek z pieśni Gustawa z IV części Dziadów.

\section{Nation with heroic feelings and spirit, czyli o narodzie polskim, którego ducha nie można złamać}

W obliczu rozbiorów Polski nasiliła się potrzeba rozwoju nauk, edukacji i utrwalenia przeszłości jako „warunku ciągłości i trwałości narodowej kultury”270. W I połowie XIX wieku coraz mocniej odczuwano konieczność całościowego ujęcia literatury polskiej, tym bardziej że zaczęły pojawiać się dzieła niemieckich autorów ukazujące ją w niekorzystnym i nieprawdziwym świetle. Jakubowski nie stworzył syntezy literatury i dziejów swojej ojczyzny, ale eseje odwołujące się do najważniejszych zjawisk polskiej rzeczywistości, jaką młody poeta starał się przekazać zagranicznemu czytelnikowi. Po Essay on a Polish Poetry zamieścił szkic o historii edukacji, który w wielu miejscach przypomina Historię literatury polskiej Bentkowskiego. Podobnie jak on podsumowywał średniowiecze jako „ciemne wieki" edukacji i tak samo $\mathrm{z}$ uznaniem wypowiadał się o Wincentym Kadłubku. Uważał, że jego kroniki, choć pełne „mitów, cudów i uprzedzeń", malują jednak obraz swoich czasów. Młody autor podkreślał przy tym, że XII-wieczny historyk nie tworzył podczas panowania królowej Jadwigi, która ufundowała Akademię Krakowską, nazwaną przez niego „kolebką nauk”271. Również Mickiewicz podkreślał w swoim kursie znaczenie tej uczelni:

Akademia Krakowska szła w zawody $z$ najstawniejszymi uniwersytetami Francji $i$ Wtoch, $z$ uniwersytetem bolońskim. W zamierzeniach naukowych owych czasów jest jakaś wspaniałość, dążność do syntezy i siła ${ }^{272}$.

Jakubowski przypominał najbardziej wzniosłe karty polskiej historii. Wspominał o Mikołaju Koperniku ${ }^{273}$, który „zmienił oblicze kosmosu i wydarł naturze

${ }^{264}$ W oryginale: Thus, our country can never perish. So much glory hangs around her name; such a spirit of sacrifice exists within her; her language enriched with poetry and songs - these all tell us she will yet exist. And we can but hope, that these songs will assist in awaking, at a future day, the sound of her revenge and salvation. Be it so. A. A. J a k u b ow s ki, The Remembrances..., s. 25.

${ }^{270} \mathrm{~S}$. S a wi cki, Poczatki syntezy historyczno-literackiej w Polsce. O sposobach syntetycznego ujmowania literatury w 1 polowie w. XIX, Warszawa 1969, s. 87.

27 A. A. Jakubowski, The Remembrances..., s. 31.

2:2 A. Micki e wi c z, Literatura stowiańska. Wykłady..., s. 149.

$27:$ Jakubowski jako pilny uczeń Liceum Krzemienieckiego powolywał się na wywody Jana Śniadeckiego, dowodzące polskiej narodowości Mikołaja Kopernika. 
jej tajemnice”274, jak również „wiek panowania Zygmuntów”, kiedy Polska była jednym z najpotężniejszych, a zarazem najbardziej tolerancyjnych państw w Europie. Oprócz Kochanowskiego wymienił jeszcze Orzechowskiego, przyrównanego do Demostenesa, oraz Modrzewskiego jako reprezentatywnych twórców tamtego okresu. W podobny do Bentkowskiego sposób opisywał panowanie Stefana Batorego jako zasłużonego założyciela Uniwersytetu Wileńskiego i „najnieszczęśliwsze" rządy jezuitów, które według autora Historii literatury polskiej „najwięcej się przyczyniły do upadku nauk i prawdziwego światła w narodzie"275. August Antoni przytaczał nawet identyczne argumenty: jałowy sposób nauczania, zbyt duży wpływ na władzę, skażenie „dobrego smaku” przez modę na panegiryzm oraz zaognianie sporów wyznaniowych. Przedstawiając upadek XVII-wiecznej kultury, podobnie jak Goszczyński w Nowej epoce poezji, widział w Konarskim wskrzesiciela narodowego ducha. Dłuższą wzmiankę poświęcił też rodzinie księcia Czartoryskiego, najprawdopodobniej ze względu na zamieszczoną w dalszych rozdziałach odezwę właśnie księcia Adama Czartoryskiego, którego zaszczytne pochodzenie chciał wcześniej przybliżyć amerykańskiemu czytelnikowi.

Szkic ten nie jest pełen „pustych ogólników”, jak pisał Krzyżanowski, ale zawiera wiele konkretnych faktów, świadczących o dużej wiedzy, oczytaniu, erudycji, a także dobrej znajomości historii. Jakubowski wspominał o utworzeniu Komisji Edukacji Narodowej oraz o Towarzystwie do Ksiąg Elementarnych. W opisie nowego systemu oświaty widać jego zakorzenienie w oświeceniowym duchu edukacji Liceum Krzemieniecego. Powoływał się na zasługi Tadeusza Czackiego, Poczobutta oraz braci Śniadeckich na polu rozwoju edukacji. Uważał, że gdyby rozwijała się ona bez przeszkód, mogłaby sprawić, że dziś Polacy równaliby się z „najbardziej oświeconymi i cywilizowanymi narodami świata"276. Poeta ukazał fatalizm losów Polski, która ledwo zaczęła się odradzać po doznanych klęskach, zaraz musiała odpierać kolejne ciosy. Podkreślał, że „polityka podstępnej Katarzyny” 277 nie pozwoliła w pełni zrealizować korzyści płynących z Konstytucji Trzeciego Maja, a także innych reform oraz zatrzymała planowane modernizacje. Działania zbrojne jej wojsk zmusiły kolejny raz Polaków, jak pisał Jakubowski, „do zamiany piór na miecze i udziału w okropnej i rozpaczliwej wojnie"278. Przypomniał bohaterską postać Kościuszki łączącą historię Polski i Ameryki, który chciał, aby w jego ojczyźnie również zapanowała wolność, stąd stanął na czele powstania. Zaznaczał przy tym, że mimo heroicznego poświęcenia całego narodu „godzina śmierci dla naszego nieszczęsnego kraju już wybiła i ani geniusz Kościuszki, ani broń jego odważnych rodaków nie pomogły go ocalić, a śmierć wolności musi zawsze i nie-

${ }^{274} \mathrm{~W}$ oryginale: Copernicus, who changed the face of the physical universe, and wrested from nature her mysteries. A. A. Ja ku bow ski, The Remembrances..., s. 31 .

275 F. B en t kow ski, Historia literatury polskiej, t. 1, Warszawa 1814, s. 147.

2i6 A. A. Ja kub ow ski, The Remembrances..., s. 36.

$2 \pi$ Ibidem.

27* W oryginale: We were once more compelled to exchange the pen for the sword, and engage in a terrible and desperate war. Ibidem, s. 36. 
uchronnie stać się i śmiercią nauki"279. Poeta w przejmujący sposób opisał despotyzm, jaki zapanował na ziemiach polskich, szczególnie dotkliwie odczuwany na prowincjach pod zwierzchnictwem Austrii, gdzie Jakubowski został uwięziony i skąd rozpoczął swoje tułacze życie. Podkreślał:

Starali się oni pozbawić nas stopniowo naszej narodowości, zepsuć nam umysty $i$ serca, jednym stowem, zabrać nam nasza pamięć, okraść nas z naszej przesztości i wykorzenić to, co wciąż ożywiato duszę naszego nieszczęsnego i znamienitego niegdyś narodu ${ }^{280}$.

Nie ma wątpliwości, że w tych słowach wyraża się również cel napisania The Remembrances... jako ratowania pamięci o ukochanej ojczyźnie na przekór działaniom zaborców. Jakubowski nazywał okupantów „barbarzyńskimi dzikusami”, na których łasce znalazły się instytucje naukowe, w tym "wielka i wspaniała"281 biblioteka Załuskich, której los przyrównał do tej zniszczonej niegdyś niemal doszczętnie w Aleksandrii. Autor zaznaczał, że nawet te wydarzenia nie były w stanie złamać narodowego ducha Polaków, którzy w różny sposób dokładali starań, aby przyczynić się do odrodzenia ojczyzny. Jedni walczyli pod sztandarami Napoleona, inni zostali $w$ kraju, by pielęgnować polską pamięć i język, tak jak Tadeusz Czacki i bracia Potoccy działający na rzecz Towarzystwa Przyjaciół Nauk założonego w 1802 roku.

Jakubowski przyznawal, że w zaborze rosyjskim zachowano przez jakiś czas dawny system edukacji, jednak z całą stanowczością demaskował prawdziwe intencje cara Aleksandra. Pisał, że lamał on postanowienia uchwalonej przez siebie Konstytucji Królestwa Polskiego, tylko pozornie zapewniając na przykład wolność prasy, gdyż w 1818 roku uwięził „liberalnego i patriotycznego dziennikarza »Orła Białego “"282. Przy okazji napomknął również o „niegodziwym i okrutnym” bracie cara - Konstantym, który bez skrupułów zamknął wspomniane pismo. Zdaniem poety „Aleksander zawsze starał się ukryć swe obłudne dążenia pod maską wspaniałomyślności. Jedną ręką podnosił naukę, a drugą ją niszczył"283. Na potwierdzenie swoich słów wskazywał Uniwersytet Warszawski założony w 1816 roku, który miał kierować edukacją docierającą do wszystkich klas społeczeństwa, co nigdy jednak nie doszło do skutku, gdyż car chciał rządzić niewolnikami, a nie obywatelami. Duch narodowy był tłamszony w zarodku, Jakubowski pisał o okrutnych prześladowaniach i torturach młodego pokolenia związanych ze śledztwem No-

2:4 W oryginale: but the hour of death had already struck for our unfortunate country; nor could the genius of Kosciusko, or the arms of his brave countrymen avail to save her; and the death of liberty must ever and inevitably produce the death of learning. Ibidem.

${ }^{2 \mathrm{HO}} \mathrm{W}$ oryginale: They alone sought to deprive us, by degrees, of our nationality; to corrupt our minds and our hearts: in a word, to take away our memory, to rob us of all the past, and to root out all that still vivified the soul of our unfortunate and long illustrious nation. Ibidem, s. 37.

${ }^{2 \times 1}$ Ibidem.

2\$2 Ibidem, s. 39.

2N.3 W oryginale: Alexander always endeavoured to conceal his hypocritical designs with the mask of humanity. He elevated education with one hand, and destroyed it with the other. Ibidem. 
-wosilcowa w sprawie Towarzystwa Filomatów i Filaretów. Poeta wskazywał absurd całej sytuacji, podkreślając, że za „samo wspomnienie wolności w wypracowaniu wtrącano ucznia do więzienia”, a na uniwersytetach zakazano „studiów nad prawami natury i narodami"284. Jednak to właśnie studenci jako pierwsi znaleźli się pod sztandarami „pamiętnej rewolucji 29 listopada"285, której duchowych patronów upatrywał w Lelewelu i Mickiewiczu. Wydaje się, że Jakubowski czytał Katechizm o czci cara drukowany w Wilnie w 1833 roku, gdyż w podobnym ironicznym tonie wypowiadał się o nakazie czczenia cara, który „panuje na ziemi jak Wszechmocny Bóg na niebie"286. W swoim piśmie August Antoni wyrażał pogląd o dramatycznej sytuacji polskiej oświaty w związku z represjami popowstaniowymi. Zaznaczał, że Rosja ustanowiła szkoły, gdzie uczy się tylko pisania i czytania, a przede wszystkim właśnie katechizmu cara. Jakubowski nie widział szans na odmianę tego stanu rzeczy, póki w kraju będzie panował despotyzm, który nigdy nie może być „przyjacielem nauki”287 ani wolności.

W kolejnej części swojej książki Jakubowski zdecydował się umieścić Dodatek zawierający krótka wzmiankę o Ukrainie $i$ Podolu. Jest on podobny do posłowia Zamku kaniowskiego Goszczyńskiego pod względem doboru informacji, jednak szkic Augusta Antoniego ma charakter bardziej poetycki. Podczas gdy Goszczyński rozpoczynał swój tekst nawiązaniem do słów krytyki, jakie Mickiewicz miał wypowiedzieć o jego dziele, Jakubowski, aby choć w części oddać piękno i wyjątkowość ukraińskich stepów, sięgnął po znaną metaforę wieszcza „suchego oceanu" (dry oceans) ${ }^{288}$. Esej Jakubowskiego, pisany z myślą o ludziach, którzy prawie nic nie wiedzą o Ukrainie, będącej dla nich egzotycznym miejscem, jest bardziej szczegółowy. Polski wygnaniec zdecydowanie więcej miejsca poświęcił w swoich rozważaniach charakterystyce Kozaków, ich mentalności i sposobowi życia. Stąd też wyjaśnił genezę buntu Chmielnickiego i pisał o jego porwanej żonie, czego nie zrobił Goszczyński. Starał się obiektywnie przybliżyć historię starć między Kozakami a Polakami. Podkreślał, że okrucieństwa popełniano po obu stronach. Kozakom, którzy najbardziej kochali wolność, przyznawał zasługi w walkach z Rosją i Turcją po stronie Rzeczypospolitej, ale jednocześnie dodawał, że kiedy zaczęli napadać na Polskę, być może spotkali się ze zbyt surową reakcją, a ich skłonna do zemsty natura nie mogła znieść czynienia z nich chłopów usługujących szlachcie. Pozytywna waloryzacja Kozaków przez Jakubowskiego pojawiła się również w zachowanym fragmencie Buntów Chmielnickiego, który w zamierzeniu autora miał być poematem narodowym. Z drugiej strony poeta zaznaczał dzikość ich usposobienia, okrucieństwo, a także łupiestwo, które nazywał ich głównym zaję-

2n. Ibidem, s. 40.

2A: Ibidem.

${ }^{2} \mathrm{H6}$ W oryginale: Russia has established schools since the revolution, in which are taught only reading and writing, with a catechism of the Emperor, who, according to its doctrines, rules on earth as the Almighty does in Heaven. Ibidem, s. 42.

2k7 Ibidem, s. 37.

${ }^{2 \mathrm{kN}}$ Ibidem, s. 62. 
ciem. Uważał, że to właśnie te przymioty zgubiły „wielkiego generała”, jak nazywał Chmielnickiego. Ubolewał nad jego oddaniem się pod protektorat Rosji i ostatecznym zerwaniem współpracy z Rzeczpospolitą, gdyż doceniał użyteczność Kozaków w polskiej armii.

Przedstawienie historii stosunków polsko-ukraińskich świadczy o dużej wiedzy piszącego. Jakubowski wykorzystywał każdą sposobność, aby pokazać Amerykanom wielkie osiągnięcia Polski i czasy jej dawnej świetności. Na przykład we wspomnianym eseju przypomniał hetmana Żółkiewskiego, który po zwycięskiej bitwie pod Kłuszynem wziął do niewoli trzech carów rosyjskich. Przedstawiał również los ukochanej Ukrainy i Podola jako ciągły teatr krwawych zbrodni. Największym nieszczęściem Polski, według Jakubowskiego, byli jej sąsiedzi, a przede wszystkim Rosja. Poeta pisał, że „okrutna polityka Rosji zawsze nękającej Polskę zachęcała ich [Kozaków] do powstań i łupiestwa"289. Nie krył też znacznego udziału carycy Katarzyny w zakończonej śmiercią ok. 20 tys. osób rzezi humańskiej, której traumatyczne doświadczenie pojawiło się także w Majorze Aleksandrze.

W opisie ostatnich dziejów Polski nie mogło zabraknąć wspomnienia Kazimierza Pułaskiego, Polaka, który nie będąc w stanie już pomóc ojczyźnie, walczył w armii Waszyngtona za wolność Ameryki i poległ pod Savannah. Chociaż w swoim dziele Jakubowski nie zawarł wielu biograficznych szczegółów, ujawnił, że Podole było kolebką jego dzieciństwa. Kiedyś nazywane „spichlerzem Polski” często stanowiło obiekt najazdów Turków, Tatarów oraz Kozaków i dlatego też stało się "teatrem najokrutniejszych scen"290. Mimo wszystko uważał je za jeden z najpiękniejszych regionów Polski, dodając przy tym, że:

nieszczęścia Podola pozostawity swój ślad na jego mieszkańcach. Tamtejsi ludzie maja pełen fantazji, romantyczny i poetycki charakter. Można rzec, że Podole jest tym dla Polski, czym Szkocja dla Anglii ${ }^{291}$.

Wspominał również o zabobonach krążących wśród podolskiego chłopstwa. Egzemplifikacja przesądów bardzo przypomina te, które opisywał Goszczyński w przypisach Zamku kaniowskiego, nadając temu miejscu mroczną, frenetyczną aurę, gdzie „każdy grób na polu i każdy krzyż ma swoją legendę" i nikt „nie umiera, gdy nie zapowie mu tego krzyk sowy albo wycie psa"292.

2ky W oryginale: The cruel policy of Russia, always harrassing Poland, continued to excite those remains to insurrection and robbery. Ibidem, s. 65 .

291) Ibidem, s. 67.

291 W oryginale: The misfortunes of Podolia, have imprinted their traces on its inhabitants. The people have a fantastic, romantic and poetic character. It may be said, with truth, that Podolia is to Poland, as Scotland is to England. Ibidem, s. 67.

${ }^{242} \mathrm{~W}$ oryginale: None of them die without the prophesy of the owl's cry or the dog's groan. Ibidem. 


\section{Such was the fate of the Polish Lovers $\mathrm{w}$ autorskim opowiadaniu Jakubowskiego}

Opowiadanie zatytułowane The Polish Lovers stanowi obok wiersza Song jeden $\mathrm{z}$ dwóch autorskich utworów Jakubowskiego w The Remembrances.... Poeta prawdopodobnie chciał nim zainteresować damy Ameryki rozczytujące się w romansach, ale przede wszystkim dzieło to było manifestacja polskiego patriotyzmu. Ukazywało dramat młodych ludzi - Haliny i Kazimierza (Casimira), którzy nie mogli odnaleźć szczęścia w miłości, kiedy „nie było go w ojczyźnie". Pod względem kompozycyjnym utwór ten był swoistym wprowadzeniem do następnego rozdziału The Causes of the Emigration of the Poles. Dzięki temu zabiegowi The fate of Polish Lovers stawał się tragicznym losem ogółu, a jednostkowy przykład wpisywał się w tragedię narodu. Jakubowski inaczej niż w Majorze Aleksandrze nie sięgał daleko w przeszłość, ale umiejscowił akcję opowiadania na tle niedawnych wydarzeń powstania listopadowego oraz partyzantki Zaliwskiego. To, co łączy oba utwory, to usytuowanie wydarzeń w rodzinnych stronach autora - "nad pięknymi brzegami Dniestru na Podolu" ${ }^{293}$.

Jarosław Ławski zastanawiał się $\mathrm{w}$ swoim artykule zamieszczonym w zbiorze Szkoła ukraińska $w$ romantyzmie polskim, czy Jakubowski znał wiersz Mickiewicza Do Matki Polki ${ }^{294}$. Wątpliwości te rozwiewa właśnie The Polish Lovers, opatrzone mottem stanowiącym tłumaczenie ostatniej zwrotki tego utworu: For his only monument shall be the dry wood of the gibbet; his only glory shall be the tears of women and the long conversations of his countrymen ${ }^{295}$. Stowa te stanowią gorzką puentę opowiadania Jakubowskiego. Główny bohater Casimir, biorący udział w powstaniu, a później w partyzantce, został pojmany przez Kozaków i okrutnie zamordowany. Choć był jedynym żyjącym jeńcem, specjalnie dla niego zbudowano szubienicę i zgodnie z rozkazem cara Mikołaja urządzono publiczną egzekucję, zmuszając okolicznych mieszkańców do uczestnictwa. Wśród nich była również Halina. Rzeczywiście „pomnikiem grobowym” Kazimierza stały się „suche drewna szubienicy”, gdyż pochowano go na miejscu kaźni. Nieprzypadkowo Jakubowski usytuował ostatnie wydarzenia swojej noweli właśnie w Józefowie. Odbyła się tam bowiem we wrześniu 1831 roku bitwa pomiędzy pododdziałami korpusów Ramorina i Rydygiera. Z ran tam odniesionych zginął młody polski oficer, hrabia Konstanty Stadnicki z Nawojowa. Równie dobrze może też chodzić o potyczkę z Kozakami z kwietnia 1833 roku, w której poległo kilku partyzantów Zaliwskiego, co w kontekście opowiadania wydaje się bardziej prawdopodobne.

293 Ibidem, s. 43.

24.4 J. L aw ski, Tragiczna i utracona..., s. 239.

295 Tekst oryginalu brzmi:

Zwyciężonemu za pomnik grobowy

Zostaną suche drewna szubienicy,

Za calą slawę krótki placz kobiecy,

I długie nocne rodaków rozmowy. 
Eugeniusz Żuk pisał, że „pełne sentymentalnej tkliwości zachowanie Haliny”296 zaciera inny wymiar bohaterki, zbliżający ją do symbolu cierpiącej Polski. Jednak wydaje się, że to właśnie patriotyzm jest najsilniej zarysowaną wartością w całym utworze. Trzy razy powraca obraz Haliny jako heroicznej bohaterki, ideału Polki, która próbuje wyzbyć się kobiecych uczuć w obliczu konieczności walki za ojczyznę. Jakubowski na potrzeby noweli stworzył piękną pieśń zatytułowaną Halina's Song, która pełna jest rozdarcia między miłością do ukochanego, lękiem o jego życie, a świadomością słuszności sprawy, o którą walczy. Pieśń ta pozostaje utrzymana w kontrastowej symbolice dobra i zła opartej na jasności i ciemności. Ostatnia zwrotka staje się świadectwem poświęcenia miłości na ołtarzu ojczyzny:

Oh! Poland! my mother, that thou may'st be free, I will conquer my sorrows and think but of thine;

And my love and my life I lay on thy shrine ${ }^{297}$.

Halina nie była jednak jednowymiarową bohaterką, przeżywała wahania i chwile słabości, dlatego też Jakubowski trzykrotnie pokazał ją jako "Polkę", a chwilę później jako kobietę, gdy nie mogła opanować wzruszenia. Opowiadanie zostało podzielone na cztery części, a każda z nich stanowi równocześnie scenę spotkania, rozstania i pożegnania. Ruiny świetnego zamku, przy których spotykali się bohaterowie, są alegorią ojczyzny, pogrzebanych nadziei i minionego szczęścia. Obrazy przyrody natomiast współgrają z uczuciami i stanami psychicznymi postaci. Jakubowski przede wszystkim pokazał w swojej noweli los polskich powstańców i patriotów, którzy za walkę o wolność ojczyzny byli traktowani jak pospolici przestępcy, ginęli haniebną śmiercią na szubienicy, a ich mogiły często były nieznane i pozbawione krzyży. Był to ostry protest przeciw wizerunkowi polskich rewolucjonistów jako bandytów, promowanego na arenie międzynarodowej przez zaborców. Poeta pokazał jednostkowy przykład tragicznego losu Polaków w ojczyźnie i na tym tle tłumaczył powody emigracji $w$ kolejnych rozdziałach.

W pierwszej części opowieści bohaterom towarzyszyła nadzieja na odrodzenie ojczyzny pokładana w powstaniu listopadowym. Mimo złych przeczuć Halina podarowała ukochanemu własnoręcznie uszyty sztandar, który Kazimierz przypiął do swojej lancy i zabrał ze sobą na pole walki, aby towarzyszył mu w chwili śmierci lub triumfu. Druga część utworu rozgrywała się w tym samym miejscu pół roku później, po klęsce rewolucji, kiedy Halina opłakiwała niewolę kraju i nieznany los Kazimierza. Chociaż powstaniec niespodziewanie powrócił, okazało się, że pojawił się tylko po to, aby pożegnać kochankę na zawsze. Świetny mundur ułana zamienił na podarty strój pielgrzyma nie po to, aby nauczać narody, ale

${ }^{24 h}$ E. Żuk, op. cit., s. 347.

2y; Thumaczenie:

O, Polsko! Matko moja, dlatego że musisz być wolna,

Pokonam moje smutki i myśląc o Tobie,

Mą miłość i życie złożę Ci w ofierze.

A. A. Jakubowski, The Remembrances..., s. 44. 
żeby znaleźć sprawiedliwość i zemstę. Nie miał w sobie pokory księdza Piotra, wybrał wygnanie, ponieważ nie potrafił zmusić dumnego serca do poddania się panowaniu despoty ${ }^{298}$. "Czym byłoby nasze życie bez wolności?" 299 - przekonywał Halinę.

W opowiadaniu pojawiają się dwa wyraźne nawiązania do Marii Malczewskiego. Przede wszystkim podczas ostatniej rozmowy zakochanych uobecnia się ironiczne echo, urągające wypowiadanym słowom. Dzieje się tak, gdy Kazimierz mówi:

Niech narody Europy ujrza plany tyranów i zadrża, widząc nasz przykład.

Żegnaj! Może spotkamy się w szczęśliwszym czasie. Nadzieja nie umarta.

Echo jednak odpowiedziato grobowym tonem: umarta ${ }^{300}$.

Również zakończenie utworu przypomina finałową scenę poematu ojca Jakubowskiego. Halina umarła przy grobie ukochanego, podobnie jak Miecznik przy mogile córki i żony. Zmarła bez słowa skargi, z pokorą ponosząc najwyższą ofiarę, realizując tym samym wspomniany ideał Polki, co autor podsumował słowami: „Taki był los polskich kochanków". Jakubowski pokazał, że miłość może zrealizować się tylko w wymiarze transcendentnym, gdyż duchy kochanków połączyły się dopiero po śmierci.

Autor w trzeciej części wytłumaczył znaczenie partyzantki, przyrównując ją do guerrillas w Hiszpanii. Miała ona stanowić preludium powszechnego powstania, a przynajmniej utrzymać w kraju ducha wolności i rewolucji. Po raz kolejny pokazał ogromne poświęcenie Polaków, ich ciągłe podnoszenie się mimo doznanych klęsk i bohaterską walkę w imię wolności nawet przy przeważającej sile wroga. Tak było również w przypadku ataku małego oddziału partyzantów na Józefów, w którym brał udział Kazimierz. Autor zarysował tutaj mit polskich wojowników, którzy mimo gorszego uzbrojenia i przybycia posiłków przeciwnika, z nadludzką siłą pokonują zastępy wrogów, będących w stanie uczynić niewielkie tylko straty w ich szczupłym oddziale. Kazimierz był jedynym żyjącym partyzantem, jakiego udało się im schwytać. Poeta w przejmujący sposób pokazał małość, bezduszność i okrucieństwo Rosjan oraz Kozaków, którzy, nie mając żadnego szacunku dla żołnierza, chcieli zemścić się na nim za wszystkie swoje niepowodzenia. W tym ujęciu ironicznie brzmią słowa Rosjan, nazywających swojego cara „świętym”, a jego rozkaz wieszania każdego buntownika traktują jako prawo zesłane od Boga. Wydaje się być to kolejnym w The Remembrances... nawiązaniem do Katechizmu o czci cara Mickiewicza, artykułu w „Piegrzymie Polskim”, informującym o próbach zaprowadzenia kultu cara, wydanym w 1833 roku.

${ }^{298}$ W oryginale: I will depart on a pilgrimage, rather than bow my proud heart to the despot [Odchodzę na tułaczkę, wolę to niż ugiąć moje dumne serce przed despotą]. Ibidem, s. 47.

299 Ibidem.

w*) W oryginale: Let the nations of Europe see the projects of tyrants, and tremble from our example. Adieu! yet, again we shall meet in happier days. The hope is not gone. But echo answered in a sepulchral tone, "gone". Ibidem. 
Mimo tragicznego końca historii w opowiadaniu pojawia się sugestia, że ofiara powstańca nie poszła na marne. Lud zmuszony bowiem przez Rosjan do oglądania egzekucji przypomina sobie chwile chwały powstania listopadowego, budzi się w nim duch narodowy, który nigdy nie zginie:

patrzyli na bohatera jak na święta ofiarę, ofiarę sktadana na ottarzu wolności. Smutna, przerażajaca ofiara! Ofiara krwi i życia! (...) tzy, piekace tzy, gardzace rozkazami despoty, spadaty wolne i nieposkromione do urny narodowego zalu i cierpienia/udręki ${ }^{301}$.

\section{The Remembrances of a Polish Exile jako manifest polityczny}

Wspomnienia polskiego wygnańca Jakubowskiego stanowią nie tylko świadectwo jego osobistych przekonań, ale posiadają również polityczny charakter. Eugeniusz Żuk pisał, że książka ta przypomina w pewnym stopniu „broszurę polityczną, a miejscami manifest" ${ }^{302}$. Na jej propagandowy charakter zwrócił uwagę także Julian Krzyżanowski. Widać w niej wyraźne paralele między najistotniejszymi pismami emigracyjnymi tamtych czasów, takimi jak: odpowiedź Komitetu Polskiego na oświadczenie Lederera, memoriał skierowany do Kongresu w 1834 roku i odezwa Do Obywateli Ameryki. Eugeniusz Żuk odnalazł poza tym treści zbieżne z kilkoma punktami wytycznych dla delegatów, którzy mieli wręczyć memoriał kongresmenom w 1834 roku. W rozdziale zatytułowanym The Causes of the Emigration of the Poles Jakubowski zrywał $\mathrm{z}$ wizerunkiem Polaka jako emigranta-dorobkiewicza, który porzucił ojczyznę, by realizować swój „amerykański sen”. Przypominał pozytywne nastawienie wielu Polaków do rewolucji francuskiej, a także historię zrywów narodowo-wyzwoleńczych od czasów Kościuszki do powstania listopadowego oraz partyzantki Zaliwskiego, zaznaczając ich doniosłe znaczenie dla krajów europejskich. Poddał także ostrej krytyce politykę carską i austriacką wobec powstańców, demaskując przyczyny odrzucenia proponowanej więźniom amnestii $w 1833$ roku. Jako jeden $z$ nich, osadzonych w Brnie i Trieście, najlepiej mógł przybliżyć kulisy postępowania zaborców i powody zesłania do Stanów Zjednoczonych. Poddał ostrej krytyce obojętność Francji, która odmówiła Polakom azylu. Patriotów postawiono przed ultimatum: wyjazd do Ameryki albo zesłanie w głąb Rosji. Autor wspomniał także o wcześniejszym wykorzystaniu Polaków przez Napoleona, których „kości bieleją na równinach Włoch, Niemiec, Hiszpanii i St. Domingo" ${ }^{303}$.

301 W oryginale: they looked at the hero as a holy offering, a sacrifice on the altar of freedom. Sad, horrible offering! the offering of blood and life! and from some, tears, burning tears, scorning the commands of the despot, rolled free and unsubdued to the urn of national sorrow and distress. Ibidem, s. 50.

${ }^{312}$ E. Żuk, op. cit., s. 348.

313 W oryginale: Their bones are whitening on the plains of Italy, of Germany, of Spain and St. Domingo, A. A. Ja ku b ow ski, The Remembrances..., s. 53. 
Książka Jakubowskiego była ważnym głosem w tamtych czasach, gdy dokładano wszelkich starań, aby skompromitować Polaków na arenie międzynarodowej. Ważyły się wówczas losy emigrantów w Ameryce, gdyż Kongres debatował nad przyznaniem polskim wygnańcom ziemi, na której mogliby się osiedlić. Rząd austriacki, który wysłał polskich patriotów do Stanów Zjednoczonych na pokładach „Hebe” i „Guerierra”, dołączył do nich grupę przestępców, aby swoim zachowaniem zdyskredytowali więźniów politycznych, o czym pisał Wojciech Konarzewski, a także Kraszewski ${ }^{304}$.

Do tej pory wśród badaczy panuje spora konfuzja i dezorientacja co do liczby i kolejności wydań The Remembranes... ${ }^{305} \mathrm{Na}$ podstawie zbiorów Fundacji Rodzinnej Blochów można zaproponować następującą sekwencję wydań The Remembrances of a Polish Exile:

1. Albany: Packard and Van Benthuysen, 1835, s. 69.

2. Auburn, NY: Allen \& Lounsbury, 1835, s. 72.

3. Philadelphia: Adam Waldie, 1835, s. 69.

4. Philadelphia: C. Sherman \& Co., 1835, s. 72 (reprinted for a Polish Exile).

5. Philadelphia: Haswell and Fleu, 1836, s. 69 (reprinted for a Polish Exile).

6. Auburn, NY: Finn \& Rockwell's Steam Power Press, 1850, s. 64.

Nie sposób nie zauważyć wyraźnego podziału na „albańskie” oraz „auburnskie" edycje tego dzieła, które cały czas się ze sobą przeplatają. Już Julian Juźwikiewicz w swoim Pamiętniku z piętnastomiesięcznego pobytu... wspominał, że bardzo szybko wśród polskich wygnańców nastąpił "rozłam” na zwolenników Karola Kraitsira, tajnego emisariusza Towarzystwa Demokratycznego w Ameryce i Antoniego Gerarda, przedstawiciela establishmentu, czyli Czartoryskiego i Niemcewicza. Ten drugi miał poparcie amerykańskich sponsorów polskiej emigracji, Alberta Gallatina w Nowym Jorku oraz Samuela G. Howe'a w Bostonie. Stąd właśnie w wydaniach „auburnskich” adresatem listów Czartoryskiego i Niemcewicza był właśnie A. Gallatin. Bardzo prawdopodobne, że druga edycja The Remembraces... była wydana $\mathrm{z}$ inspiracji Gallatina i Polaków skupionych wokół majora Gerarda. Należał do nich wtedy jeszcze Jakubowski, zaliczany do grupy „indywiduów dobrego prowadzenia się”, o czym pisał Juźwikiewicz w swoich wspomnieniach ${ }^{306}$. W edycjach z Auburn z 1835 oraz 1850 roku poza odezwą Komitetu Polskiego w Paryżu do polskich emigrantów pojawia się list otwarty "Address of Prince Adam Czartoryski to the Polish Exiles in the United States" podpisany „Paris,15th August, 1834”, a także „From Senator Niemcewicz” podpisany „Julian Ursin Niemcewicz”. Na końcu tomików znajdują się również fragmenty prozy poetyckiej The Exile's Song oraz It is weary omawiane w dalszej części książki.

w4 M $\mathrm{H}$ i m a n, Ślady polskie w Ameryce, Chicago 1993, s. 346.

${ }^{305}$ Por. Z. Wa r d z i ń s k i, English Publications of Polish Exiles In the United States: 1808-1897, "The Polish Review", Vol. XL, No. 4, 1995, s. 457-468; J. L a w s k i, P. O c z k o, Wspomnienia polskiego wygnańca, Białystok 2013, s. 44.

3k J. Juźwikie wicz, op. cit., s. 20. 
Patrząc chronologicznie, pierwsza edycja The Remembrances... została wydana w 1835 roku w ulubionej drukarni doktora Sprague'a - Packard and Van Benthuysen. Ta, a także kolejne wydanie firmy Allen \& Lounsbury okazały się niespodziewanym sukcesem i cieszyły się dużą popularnością. Na razie nie możemy mieć pewności, czy wydanie z Auburn N. Y., które Wardziński uważał za pierwsze, było drugie, czy też ukazało się równolegle z publikacją Adama Waldie'go. Również Przemysław Jan Bloch ma wątpliwości w tej kwestii. W korespondencji ze mną napisał:

Wiemy, ze Sprague byt pierwszym patronem Jakubowskiego i z pewnościq druk Packarda and Van Benthuysen w Albany N.Y., (która wydawała wszystkie pisma Sprague'a) to editio princeps. Wkrótce potem ktoś (raczej na pewno nie Sprague i Jakubowski) wydat w Auburn, N.Y. The Remembrances... $z$ "dodatkami", których nie było później u Waldiego $i$ innych filadelfijskich drukarzy. Auburn zatem to prawie równoczesne wydanie $z$ Albany, ale raczej drugie. A może równoległe $z$ Waldie'm? Adam Waldie byt zdecydowanie pierwszym wydawca The Remembrances... w Filadelfi, a trzecim $w$ kolejności (drugim jeśli Auburn byt wydany równocześnie). Rok 1835 to rok triumfu Waldiego i jego partnera w „Circulating Library" $i$ "Journal of Belle Lettres" Johna Jay Smitha.

Dzięki odnalezieniu artykułu w „Waldie’s Select Circulating Library" z 14 lipca 1835 roku wiemy, że Jakubowski musiał wcześniej udać się osobiście do Filadelfi, gdzie rozmawiał z Adamem Waldie'm, pokazując mu ostatnie wydanie swojej książki ${ }^{307}$. Koszt takiego tomiku wynosił wówczas 50 centów, co było na tamte czasy sporą sumą, a sam poeta zajmował się rozprowadzaniem i sprzedażą egzemplarzy The Remembrances... Co ciekawe, już wtedy Jakubowski i Waldie powoływali się na zasługi Kościuszki dla Ameryki, co być może było wstępem do dojścia poprzez Agrippę Hulla do szkoły Sedgwicków, gdzie polski wygnaniec pracował zanim przeniósł się do Northampton.

Wydaje się, że właśnie współpraca z tym wydawcą ugruntowała sławę Jakubowskiego jako poety w Ameryce. Wydawanie książek Jakubowskiego stało się poważnym przedsięwzięciem, a ich nakład sięgał kilkuset egzemplarzy. W zbiorach Fundacji Rodzinnej Blochów znajdują się liczne The Remembrances... pochodzące właśnie z tej edycji. Należały one do Numy Łepkowskiego, Aleksandra Bielaskiego, Mary Pierce i stanowią dowód rosnącej popularności tomiku, który stał się prawdziwym biletem wizytowym w towarzystwie.

30: „Waldie's Select Circulating Library containing the best popuar literature including memoirs, biography, novels, travels, voyages \&c", part II, Philadelphia 1835; https://books.google.pl/ books?id=vbM-AAAAYAAJ\&pg=PA434\&lpg=PA434\&dq=\%22the +remembrances + of $+a+$ polish +exile\%22\&source=bl\&ots=trjDEWd_GV\&sig=ppP4rqx7SPIKYZgez_sgn2RGa3E\&hl=en\&sa $=\mathrm{X} \& \mathrm{ei}=\mathrm{AcSeUbrTCses} 4 \mathrm{AOGzIHoAg} \# \mathrm{v}=$ onepage\&q=\%22the\%20remembrances\%20of\%20a\%20 polish\%20exile\%22\&f=false, $15 \mathrm{~V} 2013$. 
Po tym, wydawałoby się, szczytowym momencie popularności pracy polskiego wygnańca wydarzyło się coś zupełnie niezwykłego. Propozycję wznowienia dzieła Jakubowskiego złożył mu sam Colger Sherman, najbardziej wzięty wydawca ówczesnej Filadelfii. W ciągu jednego roku The Remembrances... zostały opublikowane aż czterokrotnie. W 1836 roku kolejnego wznowienia podjęła się firma Haswell \& Fleu w Filadelfii w dwóch wariantach oprawy, co również świadczyto o prestiżu autora. Była to ostatnia publikacja Wspomnień polskiego wygnańca za życia Jakubowskiego. Następna ukazała się dopiero 14 lat później i stanowiła próbę plagiatu dokonaną przez Edwarda de Novasky'ego, który zastąpił inicjały Jakubowskiego swoimi pod dedykacją To the Ladies of America. Niewykluczone, że istniały jeszcze inne wydania dzieła Augusta Antoniego. Na taki trop naprowadza pierwsza znana nam recenzja The Remembrances... wydrukowana w „Kronice Emigracji Polskiej" ${ }^{303}$. Prezentuje ona czwartą reedycję tomiku z 1835 roku, którego opis bibliograficzny pasuje do wydania Shermana, z tą różnicą, że autor tekstu krytykuje zawartą w książce rycinę przedstawiającą orła bez korony. Dostępne egzemplarze $z$ wydania Colgera Shermana nie posiadają takiej grafiki i nic nie wskazuje, aby została ona $z$ nich usunięta. W świetle przeplatających się wydań "albańskich” i „auburnskich” wydaje się prawdopodobne, że mógł być to wariant shermanowskiego wydania $z$ inicjatywy Towarzystwa Demokratycznego, gdyż brak korony na polskim orle stanowił symbol radykalnych „demokratów”. Wydania z Auburn i Albany (Filadelfia) zasadniczo się od siebie różnią. We wznowieniu albańskim z 1835 roku ze względów politycznych usunięto przesłanie stronnictwa arystokratycznego. Warto zaznaczyć, że odezwy Czartoryskiego i Niemcewicza obecne $w$ wydaniach auburnskich pokrywają się całkowicie $z$ listami wydrukowanymi w „Niles' Weekly Register” z 5 lutego 1835 roku.

Jako że Jakubowski polegał przede wszystkim na swojej pamięci, stąd w jego dziele można spotkać czasami przekręcone nazwy własne. Jednak większość z nich została poprawiona w prestiżowej edycji Colgera Shermana, której skład został zachowany przez kolejnych wydawców. Dzięki niemu „Narusznwicz” został zamieniony na „Naruszewicza”, „Wilnor” na „Wilno”, „Mickicevicz” na „Mickiewicza”, „University of Vilna” na „University of Wilno”, natomiast „Volhynia” na „Volynia". Również od czwartego wydania zmienil się podpis pod dedykacją „To the Ladies of America” (do wydania Waldie'go brzmiący: „J.A.") na „A.J.___ i występował w takiej formie w następnych edycjach. W opisie Marii Malczewskiego do edycji Waldiego mamy: „Or this description of ancient manners”, co u Shermana zostało zastąpione: „Nor this description of ancient manners”.

Ciekawym zabiegiem w czwartym wznowieniu The Remembrances... było również dodanie słów „Be it so" na końcu eseju o polskiej poezji, czego nie było w poprzednich wydaniach. Istnieją jednak pomyłki, które nigdy nie zostały poddane korekcie, do tych wyjątków należy „Krochanowski” (zamiast „Kochanowski”), „Ozrehowski” (zamiast „Orzechowski”) i „Komarski” (zamiast „Konarski”). Miniaturową antologię Sherman zamknął dość obcesowym „Finis”, czego nie zrobił wcześniej Waldie i inni wydawcy. 
Także współcześnie Wspomnienia polskiego wygnańca cieszą się sporą popularnością, o czym piszą Jarosław Ławski i Piotr Oczko w swoim polsko-angielskim wydaniu dzieła, podkreślając, że w 1990 roku wydał je Frederick Zimnoch w Northampton. Natomiast pomiędzy 2009 a 2014 rokiem aż siedmiokrotnie drukowano The Remembrances... w Stanach Zjednoczonych i dwukrotnie w Indiach, najczęściej $w$ formie reprintów ${ }^{308}$. 


\section{Major Aleksander - niepublikowana powieść Augusta Antoniego Jakubowskiego}

\section{Zapomniane i niedocenione dzieło}

Major Aleksander, jedyny zachowany fragment powieści Jakubowskiego, nigdy nie został opublikowany. Do dziś znajduje się w Bibliotece Polskiej w Paryżu, gdzie trafił dzięki Marcinowi Rosienkiewiczowi. To właśnie sporządzona przez niego rękopiśmienna edycja Pism pośmiertnych Jakubowskiego w 1839 roku stanowi jak dotąd jedyne źródło znanych nam utworów poety $w$ języku polskim. Dwa lata po śmierci Jakubowskiego Rosienkiewicz przyjechał do Filadelfii, aby tam na podstawie prywatnych notatek poety opracować tomik jego dzieł.

Podczas analizy nieznanej dotąd korespondencji Rosienkiewicza, znajdującej się w Bibliotece Polskiej w Paryżu, okazało się, że zebrał on pisma pośmiertne Augusta Antoniego, aby przekazać je Bibliotece Wydziału Historycznego w Paryżu. W tym celu nawiązał listowny kontakt $z$ jej prezesem Julianem Ursynem Niemcewiczem, którego informował o wydawanych w Stanach Zjednoczonych książkach dotyczących Polski, recenzował je oraz zaznaczał strony z najważniejszymi fragmentami. Odpowiadając na wiadomości Rosienkiewicza z 25 sierpnia i 25 września 1839 roku, Niemcewicz w liście datowanym na 28 kwietnia 1840 roku potwierdzał w postscriptum, że poezje Jakubowskiego dotarły do niego oraz do Eustachego Januszkiewicza. Dodawał również, że na pierwsze wezwanie Komitetu pomnika śp. Klaudii Potockiej „rękopisma” zostaną mu przekazane do stosownego użytku. Tłumaczy to fakt, że na początku Pism pośmiertnych znajduje się adnotacja: „Na dochód Pomnika ś.p. Klaudyi Potockiej”.

Oryginalny rękopis, mający postać 71 stron niewielkiego notatnika, zawierał: Wiadomość biograficzna o Jakubowskim, 42 utwory liryczne oraz fragment pt. $M a$ jor Aleksander. Choć stanowił on integralną część tomiku, nie został włączony do wydania Juliana Maślanki, który poświęcił jej we wstępie następującą notę:

Oprócz 42 utworów poetyckich rękopis zawiera drobny fragment prozy. Sa to trzy pierwsze rozdzialy powieści historycznej zatytutowanej "Major Aleksander", powieści z czasów Napoleona, o wojewodzicu Zarembie i jego nieszczęśliwej mitości do pięknej Wandy, chtopskiego pochodzenia wychowanicy ojca. Powieść tę napisat Jakubowski po angielsku, z myśla już o amerykańskim czytelniku. Ttumaczenie swe - trudne do oceny bez znajomości oryginatu - zaopatrzyt Rosienkiewicz nota: „Dalszego ciągu tej powieści nie można byto znaleźć pomiędzy papierami Jaku- 
bowskiego. Jeśli jest w czyim ręku, zapewne badź po angielsku, bagdź w ttumaczeniu, przestana będzie do ogtoszenia"309.

Myśl o trzech rozdziałach zaginionej powieści historycznej syna Malczewskiego, która nigdy nie ujrzała światła dziennego ani nie stała się przedmiotem pogłębionych badań historycznoliterackich, nie dawała mi spokoju. Rosienkiewicz, mimo zaginięcia prawie całości materiału Majora Aleksandra, umieścił zachowane fragmenty w planowanym wydaniu i przesłał na ręce samego autora Spiewów historycznych.

Aby dopełnić obrazu twórczości młodego wygnańca, a także w nadziei, że utwór ten może rzucić światło na wciąż pełne tajemnic tragiczne życie Jakubowskiego, postanowiłam sprowadzić kopię rękopisu Pism pośmiertnych z Biblioteki Polskiej w Paryżu. Udało się to dzięki uprzejmości i pomocy Ewy Rutkowski, kierownika archiwum tej biblioteki.

Największym zaskoczeniem okazał się fakt, że Major Aleksander wcale nie był tytułem całego dzieła Jakubowskiego, a jedynie jego pierwszego rozdziału. Rosienkiewicz zatytułował bowiem utwór przyjaciela jako Powieśc ${ }^{310}$. Liczy ona 15 stron formatu $21 \times 17,5 \mathrm{~cm}$, a po dokonaniu transkrypcji rękopisu okazuje się, że ma prawie 20 tysięcy znaków. W przybliżeniu daje to 9 stron znormalizowanego maszynopisu. Należy zaznaczyć, że w przygotowanym wydaniu Rosienkiewicza znajduje się również fragment czwartego rozdziału. Poszczególne części utworu zostały zatytułowane: Major Aleksander, Powieść starego Tomasza, Mtodość Aleksandra, Wanda. Nie znamy dokładnej daty napisania tego dzieła, ale dzięki Wiadomości biograficznej Rosienkiewicza wiemy, że powstało ono w Stanach Zjednoczonych, gdyż pierwotnie Major Aleksander został napisany w języku angielskim ${ }^{311}$. Po analizie tekstu rękopisu okazało się, że jego redaktor nie zawarł żadnych bliższych informacji dotyczących powieści. Jedynie w przypisie na samym końcu utworu zaapelował o przesłanie jego dalszego ciągu „bądź w języku angielskim, bądź w tłumaczeniu"312. Oznacza to, że były nauczyciel Liceum Krzemienieckiego nie dysponował całą spuścizną literacką Jakubowskiego i podejrzewał, że pozostaje ona jeszcze w innych rękach.

Być może zachowane fragmenty utworu były tylko rusztowaniem, na którym Jakubowski chciał dopiero zbudować gmach swojej powieści. Swiadczy o tym brak sprecyzowanego tytułu, a także skupienie się przede wszystkim na akcji, pędzącej w zawrotnym tempie, z pominięciem pogłębionych portretów psychologicznych bohaterów oraz opisów przyrody, pojawiających się rzadko na kartach powieści. Z drugiej strony Rosienkiewicz w Wiadomości biograficznej zaznaczał,

309 A. A. Ja kubowski, Poezje, s. XII.

310 Tytuł Powieść ma nieokreślone pochodzenie, gdyż może być on tłumaczeniem angielskiego „novel" albo beztytułowym fragmentem narracyjnym. W niniejszej książce będę jednak posługiwać się tytułem Major Aleksander, jakim nazwał ten utwór Julian Maślanka.

311 M. R osi enkie wi c z, Wiadomość biograficzna..., s. 69.

312 Ibidem. 
że jego przyjaciel „wszystkie wiersze w pamięci wyrabial, a potem dopiero za papier chwytał"313 i małą wagę przywiązywał do ich „powierzchowności". Jednak stwierdzeniu temu przeczy bogactwo gatunkowe oraz dopracowanie formalne niektórych utworów, a także oryginalne przetwarzanie powszechnie przyjętych wzorów wersyfikacyjnych.

Należy także podkreślić, że w przypadku Majora Aleksandra parcjalność, w ujęciu Kazimierza Bartoszyńskiego ${ }^{314}$, ma charakter jedynie domyślny, ponieważ nie dysponujemy pełną wersją utworu. Wobec tego fragment staje się całością, wymagającą szczegółowej analizy. Bartoszyński podkreślał również, że „posiadanie tytułu jest dowodem, że tekst jest dziełem literackim, a odmawianie mu tytułu dokumentuje jego fragmentaryczność" ${ }^{315}$, powołując się przy tym na Powieść bez tytułu Kraszewskiego. Podobna sytuacja „nazwania przez odmowę nazwania" występuje w Majorze Aleksandrze, opatrzonym jedynie tytułem Powieść. Jednak nie wydaje się, aby był to celowy zabieg Jakubowskiego, a jedynie wynik niedokończenia dzieła, znajdującego się w prywatnych notatkach autora.

Kompozycja, charakterystyka głównych bohaterów oraz świata przedstawionego utworu zostaną omówione w kolejnych podrozdziałach, warto jednak w tym miejscu przynajmniej skrótowo zarysować jego fabułę. Akcja Majora Aleksandra rozgrywa się między 1798 a 1801 rokiem w czasie wyprawy egipskiej Napoleona. Pierwszy rozdział przybliża tajemniczą sylwetkę głównego bohatera Aleksandra Auberta, który zdaje się realizować romantyczny model „życia w masce”. Służył w armii Napoleona jako oficer jazdy i tak jak bohater bajroniczny naznaczony jest piętnem osobistej tragedii, która odebrała mu radość życia. Choć trzymał się na uboczu, gardził śmiercią i innymi ludźmi, budził jednak ich szacunek, gdyż wyróżniał się walecznością i nie zależało mu na materialnych korzyściach. Jego najbliższym przyjacielem pozostawał pies Filaks, przypominający mu utracone na zawsze szczęśliwe czasy spędzone w ojczyźnie. Kiedy po jednej z bitew Filaks nie wrócił ze swym panem do obozu, zrozpaczony major wyznaczył za odnalezienie pupila nagrodę w wysokości trzech tysięcy franków. Gdy wydawało się, że pies bezpowrotnie zaginął, nastąpił niespodziewany zwrot akcji - Filaks został przyprowadzony przez starego grenadiera, który odbił go z obozu Arabów, gdzie pies był przetrzymywany. Nie chciał jednak przyjąć nagrody, a w czasie rozmowy wyjaśnil, że identycznego psa posiadał w Polsce wojewoda Zaremba. Wyznanie to uczyniło piorunujące wrażenie na rannym Aleksandrze, który rozpoznał w przybyszu Tomasza, sługę swojego ojca. Po chwili radosnego powitania Tomasz opowiedział o swoim przyłączeniu się do generała Dessaix, którego oddział niedawno przybył do Egiptu, a przede wszystkim o śmierci wojewody Zaremby, o czym Aleksander nic nie wiedział. „Po zbyt silnym wzruszeniu” major udał się na spoczynek. W tym czasie Tomasz zaczął opowiadać kolegom w obozie historię panicza, nie przytoczoną wprost, ale zrelacjonowaną przez narratora. Ukazane

111 Ibidem, s. 68.

114 K. B a r t os z y ń s k i, Powieść w świecie literackości. Szkice, Warszawa 1991, s. 146.

11: Ibidem, s. 147. 
koleje życia młodego Aleksandra, kończące się zapowiedzią tragedii miłosnej, są pełne wątków autobiograficznych.

\section{Autobiografizm Majora Aleksandra}

Alina Witkowska nazwała poezje Jakubowskiego pamiętnikiem jego duszy ${ }^{316}$. Również zachowane fragmenty Majora Aleksandra stanowią w dużej mierze odzwierciedlenie życia syna Malczewskiego. Jawi się on nie tylko jako duchowy dziedzic talentu swojego ojca, ale również jego fatalnej doli. Rosienkiewicz w Wiadomości biograficznej wskazywał, że życie Jakubowskiego od samego początku realizowało fatalistyczny scenariusz: „Zaledwie ujrzał światło słoneczne, jużci posępna chmura żałoby okryła kolebkę jego - okoliczności bowiem tak zrządziły, że w dziesiątym dopiero roku życia poznał rodziców, których sądził się być pozbawionym"317. Bardzo podobna metaforyka pojawia się w Majorze Aleksandrze, gdzie główny bohater jest „samotny od kolebki”, a „pierwsze dni jego życia zasępione były boleścią"318. Słusznie podkreślał Jarosław Ławski, że Malczewski wspominał o metaforycznym cierniu życia, który kaleczy egzystencję, natomiast jego syn już się z nim urodził ${ }^{319}$. Wizja dzieciństwa kreowana przez Jakubowskiego ma jednak charakter dychotomiczny w przeciwieństwie do jego liryki, gdzie lata spędzone na Podolu stanowią przedmiot największej nostalgii i zawsze kontrastują z beznadziejną teraźniejszością. Z jednej strony chłopięce lata są czasem bezpowrotnie utraconego szczęścia ${ }^{320}, \mathrm{z}$ drugiej zaś prefiguracją dojrzałości. W pewnym stopniu Aleksander przypomina bohaterów Godziny myśli Słowackiego. Indywidualistyczne odosobnienie oraz piętno wykluczenia sprawiło, że młodzieniec „wcześnie przyuczał się żyć w świecie własnych myśli”321. Rzeczownik „myśl” bardzo często powraca w dorobku poetyckim Augusta Antoniego w różnorodnych aspektach. Na etapie lat młodzieńczych jawi się zwykle jako "goniec wyobraźni", a także przejaw geniuszu mogącego przeniknąć tajemnice natury i historii. Należy zaznaczyć, że ruch myśli zawsze wznosi się w porządku wertykalnym, poza granice świata, gdzie poeta doznaje młodzieńczej ekstazy. Dlatego nie dziwi fakt, że narrator Majora Aleksandra tak mówi o głównym bohaterze:

młody orzet sit swoich próbowat, tam marzył o szczęściu, którego rzeczywiście doświadczat $i$ które wystawiat sobie nadal w najzywszych kolorach ${ }^{322}$.

Jak wspominałam, Bachelard pisał, że wyobraźnia związana z powietrzem, w przeciwieństwie do tej odnoszącej się do wody czy ognia, tworzy szczęśliwe

\footnotetext{
${ }^{316}$ A. Wit kow ska, Romantyzm, „Rocznik Literacki” 1973, s. 249.

${ }^{317}$ M. Rosie nkie wi c z, Wiadomość biograficzna..., s. 67.

${ }^{31 k}$ A. A. Ja kubowski, Pisma pośmiertne, s. 64.

319 J. Ławski, Tragiczna i utracona..., s. 248.

${ }^{3211}$ Porównaj z wierszami Jakubowskiego, takimi jak: Dumanie I, Podole, Przeszłość.

321 A. A. Ja kub ow ski, Pisma pośmiertne, s. 64.

322 Ibidem.
} 
obrazy radości i wzniosłości, a lot jest metaforą pragnienia wzniosłości oraz siły uduchawiającej ${ }^{323}$. Podobne obrazowanie można spotkać w lirykach Jakubowskiego, takich jak Przemiana czy Ideaty. Natomiast orzeł jako symbol potęgi i sily także pojawia się w jego poezjach, na przykład w Uniesieniu przypominającym swoją ekspresją Wielką Improwizację, gdzie następuje deifikacja „ja” lirycznego pod wpływem marzenia.

$\mathrm{Na}$ ambiwalentne doświadczenie dzieciństwa Aleksandra składa się również to, że podobnie jak Jakubowski wychowywał się bez ojca, a częściowo bez matki. Kreacja wojewody pod pewnymi względami przypomina Malczewskiego. Tak jak on sporo czasu spędził na podróżach zagranicznych, a co najważniejsze - opuścił matkę swojego syna na Ukrainie (!), sam natomiast wyjechał do Warszawy. Wiemy jednak, że poeta darzył autora Marii wielkim szacunkiem i był dumny $\mathrm{z}$ ich bliskiego pokrewieństwa. W przedstawieniu ojca Aleksandra można się dopatrzyć pewnej idealizacji, usprawiedliwienia jego poczynań jako wynikających z patriotycznego obowiązku, dla którego porzuca on szczęście rodzinne.

Bohater powieści, podobnie jak Jakubowski, nie miał takiego kontaktu z ukochaną matką, jakiego by pragnął. Wprawdzie miała ona „staranie około wychowania syna"324, ale więcej czasu spędzała na modlitwach, będących dla niej formą eskapizmu po wyjeździe męża. Aleksander utracił Julię w nagłych i strasznych okolicznościach, zamordowaną w wyniku buntu Gonty. Także poeta niespodziewanie został na zawsze oddzielony od matki przez „wypadki rewolucji 29 listopada", co podkreślał Rosienkiewicz ${ }^{325}$.

W Majorze Aleksandrze można również doszukać się realizacji kolejnego wątku biograficznego poety, jakim było oddanie go przez rodziców na wychowanie opiekunom. Wedle Wiadomości biograficznej Jakubowski miał przez 10 lat mieszkać z obcymi ludźmi, sądząc, że jest sierotą. Z kart powieści dowiadujemy się natomiast, że Aleksander jeszcze za życia matki został powierzony staraniom wiernego sługi ojca - Bartłomieja. To właśnie on uratował chłopca w czasie napadu hajdamaków na zamek wojewody. Po śmierci rodziców znalazł schronienie w chłopskiej posiadłości Bartłomieja i jego żony. Kiedy dotychczasowi opiekunowie także umarli, Aleksander stał się nauczycielem ich pięknej córki - Wandy, z którą połączyło go płomienne uczucie.

\section{Echa Marii w Majorze Aleksandrze}

Nie ulega wątpliwości, że jedną z największych inspiracji dla powieści Jakubowskiego była Maria - dzieło jego ojca, które nazwał w The Remembrances... nieśmiertelnym pomnikiem chwały Malczewskiego, mogącym rywalizować z utworami samego Mickiewicza. Najwięcej podobieństw można dostrzec w trze-

323 Por. G. Bachelard, Wyobraźnia poetycka. Wybór pism, tlum. H. Chudak, wstęp J. B loń ski, Warszawa 1975, s. 181-220, Biblioteka Krytyki Wspótczesnej.

324 A. A. Jakubowski, Pisma pośmiertne, s. 63.

${ }^{32.5}$ M. Rosienkiewicz, Wiadomość biograficzna..., s. 67. 
cim rozdziale pt. Młodość Aleksandra - zarówno w zakresie miejsca akcji, przebiegu fabuły, jak i w kreacji poszczególnych bohaterów. Tak jak w Marii opowieść rozgrywa się na Ukrainie, między innymi w starym zamku nad Dnieprem, siedzibie rodowej Wojewody. Zarys fabularny jest bardzo zbliżony: wojewoda Zaremba posiadał jedynego syna Aleksandra, który zakochał się w dziewczynie niższego stanu - Wandzie. Nie wiemy jednak, czy to ojciec próbował rozdzielić zakochanych, gdyż powieść urywa się zapowiedzią tragedii pary. Początek utworu wyraźnie wskazuje na ostry konflikt między ojcem a synem, zakończony definitywnym zerwaniem kontaktu. Możemy się domyślać, że tak jak w poemacie Malczewskiego, zarzewiem sporu stał się mezalians, tym bardziej że wybranka Aleksandra nie była tak jak Maria przedstawicielką zubożałej szlachty, ale miała chłopskie pochodzenie. Pewny wydaje się fakt, że Zaremba nie posunął się do podstępnej zbrodni jak ojciec Wacława, ponieważ Aleksander nie pałał do niego nienawiścią, ale dręczył się wyrzutami sumienia, że rozstali się w niezgodzie. Młodzieniec zastanawiał się nawet, czy ojciec nie wyparł się go. O tym, że wciąż żywił do niego serdeczne uczucia, świadczy fragment powieści:

Opowiadanie Tomasza byto długie, lecz gdy przyszedt do opisania śmierci Wojewody, tzy rzęsiste zrosity policzki Majora. „Byłeś więc obecny śmierci mojego ojca?” zapytat. - "Bytem - odrzekt westchnawszy Tomasz. - „Czy wspomniat swego syna?” - „O!' wiele i często mówit o panu - saddzit cię być umartym i obwiniat, że się może przyczynit do twojej śmierci - i błogosła wit pamięc twoja w ostatnim zgonie." - „I nie przeklinat mię?” - westchnąt gtęboko Major. Tu, długo uśpione uczucia jego obudzać się zaczęty ${ }^{326}$.

Z zachowanej części powieści wyłania się obraz Zaremby jako zupełne przeciwieństwo Wojewody z Marii. Ojciec Aleksandra nie był intrygantem, ale człowiekiem szlachetnym o „prawdziwie polskim sercu”. Pochodził ze znamienitego rodu, a zdobytą w podróżach wiedzę pragnął wykorzystać do naprawiania Rzeczypospolitej. Dobro kraju przedkładał nad szczęście rodzinne. Po śmierci Augusta III zostawił młodą żonę i syna, a sam wyjechał do Warszawy, gdzie zajmował się sprawami publicznymi. $Z$ tego powodu nie zdołał uratować Julii, gdy kozacy Gonty przypuścili atak na ich zamek. Zmarł wkrótce po jej śmierci i utracie syna, nękany poczuciem winy.

Julia natomiast przypomina Marię ze względu na swoją religijność. W obu utworach pojawiają się podobne motywy wizji mistycznych oparte na ruchu wertykalnym, symbolizującym przekraczanie ziemskich granic i połączenie się w ekstazie z sacrum. Malczewski porównywał tytułową bohaterkę swojego dzieła do gołębicy, która "wzbija ducha wiary” i "gniazda szuka daleko od ziemi" ${ }^{22}$. Tak samo Julia: „Czyste jej i niewinne serce wznosiło się na skrzydłach wiary do przybytku Pana" ${ }^{328}$. Jakubowski dodawał również: „Często widzieć ją było można 
klęczącą w kaplicy zamkowej pod obrazem przeczystej Matki Zbawiciela i polecającą opiece Ojca Przedwiecznego siebie, małżonka, ojczyznę i syna" ${ }^{\prime 29}$. Również Maria pojawia się na kartach powieści poetyckiej, pochylona nad „księgą żywota” i pogrążona w modlitwie. Mickiewicz w swoich prelekcjach paryskich nazwał Marię „ideałem Polki" ${ }^{330}$. Zdaniem wieszcza nie jest ona rozegzaltowaną czytelniczką romansów, ale kobietą, która odważnie przyjmuje ciosy losu i wspiera męża w jego decyzjach. Mimo najgorszych przeczuć, nie powstrzymuje Wacława przed walką z Tatarami. Rozumie pierwszeństwo obowiązku patriotycznego i chce towarzyszyć ukochanemu w niebezpieczeństwach. Podobnie Julia nie zatrzymuje Wojewody przed wyjazdem do Warszawy, choć wie, że czeka ją samotność. Nie czyniąc mu wyrzutów, oddaje się religii i wychowaniu syna, a w modlitwach poleca Bogu zarówno męża, jak i ojczyznę, której poświęcił życie.

Losy bohaterek łączy także tragiczny koniec ich życia - obie padają ofiarą okrutnego morderstwa. Julia w scenie przypominającej Sen srebrny Salomei zostaje pozbawiona głowy, zatkniętej później na baszcie zamku. Bezbronna Maria ginie natomiast utopiona przez zamaskowanych wysłanników Wojewody. Bogusław Dopart pisał, że Maria objawia Wacławowi śmierć w całej jej „grozie i brzydocie" 331 . Podobnie Julia ukazuje marzącemu o szczęściu Aleksandrowi, zamkniętemu dotąd $w$ hermetycznym świecie fantazji, okrutne prawo silniejszego. Jakubowski w przedstawieniu rzezi humańskiej uniknął „krwawej powodzi”, którą Michał Grabowski wytknął Zamkowi kaniowskiemu. Syn Malczewskiego ukazał ją natomiast w mgnieniu chwili i błysku płomieni, ale przede wszystkim jako projekcję autentycznego poczucia grozy. Było to wydarzenie o bardzo dużym znaczeniu dla szkoły ukraińskiej i choć odległe w czasie powracało w utworach kolejnych pokoleń. W przedstawieniu Augusta Antoniego stało się ono niezwykle drastyczne poprzez zestawienie z figurą matki, która w całej twórczości Jakubowskiego jawi się jako najbardziej pozytywna i ukochana osoba dla młodego wygnańca.

Jakubowski przyrównał rzeź dokonaną przez hajdamaków oraz zabójstwo Wojewodziny do godła „piekielnych Saturnaliów”. W starożytnym Rzymie były to swawolne uroczystości ku czci Saturna (greckiego Kronosa) przypadające na koniec roku. Przypominały tradycję średniowiecznego karnawału, świata na opak, gdyż w czasie tego święta zacierały się różnice społeczne. Niewolnicy rozkazywali panom, którzy usługiwali im przy stole. Rzeczywiście Iwan Gonta - setnik kozacki, a zarazem dowódca dworskiej policji Franciszka Salezego Potockiego, zdradził swojego pana i zamiast mediować ze zbuntowanym chłopstwem, przyłączył się do rebelii. Jego oddziały razem z grupą Maksyma Żeleźniaka wymordowały prawie 20 tysięcy mieszczan, szlachty i Żydów.

Z kolei Włodzimierz Szturc wskazywał na możliwość odczytania Marii przez lustro ryciny Michaela Coxciego oraz sztychu Martena van Heemskercka Saturn

${ }^{329}$ Ibidem.

330) A. Micki ewi c z, Prelekcje paryskie, s. 146.

331 B. D o pa r t, Romantyzm polski, pluralizm prądów i synkretyzm dzieta, Kraków 1999, s. 65. 
$i$ jego dzieci ${ }^{332}$. Oba dzieła obrazują podporządkowanie całego świata potędze czasu jako niepokonanej sile, którą uosabia Saturn, nazywany przez astrologię „Wielkim Złoczyńcą". Śmierć rządząca naturą staje się odpowiednikiem ruiny ludzkiego świata, śmierci w kulturze i cywilizacji. Bezpowrotnie do przeszłości odchodzi bezpieczny dom, w którym wychował się Aleksander, a także beztroskie dzieciństwo. Jakubowski zarysował wyraźny kontrast między „najsłodszym snem niewinnego wieku" a obrazem krwawych mordów i okrutnej śmierci matki. Od tej chwili staje się mężczyzną, który musi zaopiekować się Wandą. Chwile spędzone $z$ ukochaną na rodzinnym Podolu autora stają się jedyną w całej twórczości Jakubowskiego przestrzenią urzeczywistnienia archetypu locus amoenus. Każda inna próba odnalezienia albo stworzenia azylu, miejsca wolnego od cierpienia i śmierci, kończy się w utworach poety niepowodzeniem. Saturn to także symbol melancholii - jest ona jednym z głównych kluczy do świata Jakubowskiego, a poeta stał się jej więźniem. W tym aspekcie Jakubowski podobnie jak jego ojciec tworzy model jaźni wyobcowanej i zamkniętej w sobie, postrzegającej tylko własne projekcje, co powoduje rozpacz podobną do tej odczuwanej przez więźniów jaskini Platona, a w tym wypadku - więźniów Saturna.

Mimo pozornego podobieństwa utwory ojca i syna różnią się w przedstawieniu uczucia zakochanych. $Z$ początku wydaje się, iż oba dzieła ukazują jeden z najważniejszych w kulturze europejskiej wzorów miłości, stworzonego przez Platona w Uczcie, a Wanda i Aleksander kochają się miłością prawdziwie romantyczną, odnajdują w sobie brakującą cząstkę swego „ja", tworząc duchową jedność. Jednak słowa: „Nie było uczucia w sercu Aleksandra, którego by Wandy serce nie mieściło - nie było myśli, którejby i ona w tejże chwili nie miała" ${ }^{333}$, nie są obrazem idealnego porozumienia, ale sentymentalnej utopii przekazu z duszy do duszy.

Jakubowski w najbardziej poetyckim rozdziale zatytułowanym Wanda dokonał hiperbolizacji miłości i obrazu zakochanych, posługując się anachroniczną topiką sentymentalną. Nie uniknął rekwizytów nieodzownych dla "czułej” scenerii, takich jak: flety pastusze, mruczące strumyki, śpiewające słowiki, zefiry całujące kwiaty, blask księżyca oświetlający miejsce schadzek czy porównania ukochanej do róży. Obraz miłości pary dopełnia scena, w której Julia i Aleksander obejmują się na skale pod „baldachimem nieba”, wpisująca się w typowe obrazowanie romantyczne ${ }^{334}$. W Zamku kaniowskim również znajdziemy scenę spotkania pary darzącej się zakazaną miłością przy świetle księżyca, ale w jakże odmiennej tonacji - towarzyszy jej skrzypienie szubienicy, wycie psów oraz szatańskie "pustoty”. W powieści Jakubowskiego mrok z całą swoją okropnością jeszcze nie daje w pełni o sobie znać, dopiero wkrada się w sielankowe dekoracje. Świat powieści to rzeczywistość widziana oczami zakochanych, niedostrzegających otwierającej się pod ich stopami przepaści, która pochłonie ich szczęście.

332 W. Szturc, O obrotach sfer romantycznych. Studia o ideach $i$ wyobraźni, Kraków 1997, s. 176.

333 A. A. Ja kubow ski, Pisma pośmiertne, s. 67.

33 Możemy tutaj wskazać na różnorodną symbolikę góry: wyniesienia ponad światem, nawiązania kontaktu z rzeczywistością transcendentną czy sakralnych opozycji: góra - dól, dobro - zło. 
Wobec tak zarysowanego uczucia Wandy i jej opiekuna natura staje się jedynie tłem i piękną scenerią. Zupełnie inaczej dzieje się w Marii, gdzie przyroda zyskuje rangę ważnego uczestnika zdarzeń w kreowaniu świata przedstawionego. $\mathrm{Z}$ jednej strony w Majorze Aleksandrze „samo (...) położenie i okolica miłość wzniecały", a z drugiej przyroda jawi się również jako niemy świadek zbrodni. W scenie napadu Gonty mrok skrywa okrucieństwa rzezi, płomienie jako symbol zniszczenia odsłaniaja jej ofiary. Natomiast w poemacie Malczewskiego natura zostaje ukazana jako złowieszcza antycypacja losów bohaterów, często ironicznie urągająca ludzkim nadziejom. Świat zanurzony jest w nicości, w żadnym jego miejscu prawdziwe szczęście nie jest możliwe. Z kolei w Majorze Aleksandrze przyroda nie jest zarażona pierwiastkiem zupełnego pesymizmu i nie podlega w całości bezwzględnemu prawu przemijania. Ostatnie zdanie Majora Aleksandra brzmi: „Skały tylko zimne i nieczułe, te trwać będą długo, długo" 335 .

Dzika natura Ukrainy uwrażliwia Aleksandra i napełnia jego duszę poetyckimi wyobrażeniami. Co ciekawe, Jakubowski, opisując przyrodę ukraińską, najczęściej sięga właśnie po epitet: „dziki”, zupełnie tak jak jego ojciec ${ }^{336}$. Również Aleksander Tyszyński w swojej powieści dydaktycznej Amerykanka w Polsce wskazywał właśnie „ponurość i dzikość” jako główne cechy szkoły ukraińskiej ${ }^{337}$. W zachowanych fragmentach utworu nie uderza obsesja śmierci, będąca dominantą $w$ lirykach Jakubowskiego oraz poemacie Malczewskiego, jednak główny bohater powieści podobnie jak Maria jest częściowo zarażony śmiercią. Nieprzypadkowo August Antoni, tłumacząc w The Remembrances... dwa wyjątki z poematu ojca, jako pierwszy wybrał fragment zawierający opis Marii jeszcze pięknej, ale już gasnącej, zawłaszczanej przez śmierć i zdającej się należeć już do innego świata ${ }^{338}$. W pierwszym rozdziale powieści Aleksander również jest przedstawiony jako przystojny młodzieniec, którego oczy płoną ogniem omdlałym i grobowym ${ }^{339}$. Identycznych epitetów używał Jakubowski w wierszu Do J.B., gdzie miłosne wyznanie przytłoczone zostaje pewnością nieuchronnej śmierci.

Należy również zwrócić uwagę na fakt, że w Marii oraz w Zamku kaniowskim rzeczywistość ukazana jest przez pryzmat wierzeń i przesądów ludowych, gdzie nic nie dzieje się bez przyczyny. Nawet wicher nocny jawi się jako pierwsze narzędzie diabelskich mocy. U Jakubowskiego świat przedstawiony odarty zostaje $\mathrm{z}$ transcendencji, dopiero sam koniec utworu zaczyna przypominać fatalizm Marii:

Szczęście ich było bez granic - długo więc trwać nie będzie. Jest bowiem jakaś skryta moc, moc dzielna, wielowtadna, która wszystkiemu co jest szczęśliwe, wielkie,

13i A. A. Jakubowski, Pisma pośmiertne..., s. 68.

136 Por. J. Maśla nk a, Z dziejów literatury i kultury, s. 93.

317 A. Tys z ý ski, O szkolach poezji polskiej, [w:] i de m, Amerykanka w Polsce, cz. II, St. Petersburg 1837, s. 177.

33.4 Por. Maria, Pieśn I, cz. IX, w. 213-226, [w:] Antoni Malczewski, jego żywot..., s. 37.

${ }_{134}$ A. A. Jakubowski, Pisma pośmiertne..., s. 54. 
potężne, szepce: "nie będziesz trwać długo". Skaty tylko zimne i nieczułe, te trwać będą dtugo, dtugo ${ }^{340}$.

\section{Kwestie genologiczne Majora Aleksandra}

Jeszcze w początkach XIX wieku romans postrzegano jako gatunek z marginesu literatury, a jego częściowa nobilitacja nastąpiła dopiero po roku 1815. Ignacy Krasicki w Zbiorze potrzebniejszych wiadomości opatrzył romans definicją: „nazwisko historii zmyślonych, po większej części miłosne awantury w sobie zawierających" ${ }^{341}$, natomiast w traktacie $O$ rymotwórstwie $i$ rymotwórcach stwierdził, że powieść to przede wszystkim fabuła ${ }^{342}$. Konieczność zdecydowanego rozgraniczenia romansu i powieści odczuwali również teoretycy i krytycy literatury przed 1831 rokiem. W słowniku Lindego możemy przeczytać: „słowo powieść oznacza ustny przekaz wiadomości, czynność opowiadania, narrację, nadto wieść i pogłoskę oraz sentencję i przypowieść"343. Jednak nie tylko praktyka autorów, ale również rozważania teoretyczne i krytyczne pokazują, że to romans pozostawał nazwą gatunku, podczas gdy powieść stała się jego odmianą i miała znaczenie krótkiego utworu fabularnego. Do tej grupy zaliczał się Józef Korzeniowski, absolwent Liceum Krzemienieckiego, który w 1823 roku, po śmierci Alojzego Felińskiego, przyjął stanowisko profesora wymowy, poezji, literatury polskiej i estetyki ${ }^{344}$. Zajmował je aż do zamknięcia szkoły w 1832 roku, a zatem był on nauczycielem młodego Jakubowskiego przez cały okres jego nauki w Atenach Wołyńskich. Syn Malczewskiego darzył go wielkim szacunkiem, na kartach The Remembrances... uznał, że tkwi w nim zalążek najwyższego geniuszu (embryo of a superior genius), który pozwolił mu otworzyć nową erę polskiej tragedii i obudził śpiącą Melpomenę. Z pewnością uczył się poetyki oraz teorii literatury na podstawie popularnego Kursu poezji autorstwa Korzeniowskiego, traktowanego jako wzorcowy podręcznik jeszcze przez kilkanaście lat po rozwiązaniu Liceum Krzemienieckiego. Zagadnieniu powieści autor poświęcił dwa rozdziały w swojej pracy: O powieści poetyczney i alegoryczney oraz IX rozdział pt. O Romansie. Romans, podobnie jak powieść, Korzeniowski zaliczał do „poezji opowiadającej”. Krótsze formy narracyjne nazywał „właściwymi powieściami”345, które „nie wymagają ani wielkości przedmiotu, ani trudnego zawikłania"346. W tym ujęciu powieść stawała się odmianą romansu, charakteryzowanego jako „opowiadanie

34) Ibidem, s. 68 .

311 I. K racicki, Zbiór potrzebniejszych wiadomości, porządkiem alfabetu utożonych, t. 2, Warszawa Lwów 1781, s. 454.

${ }^{322}$ Stownik literatury polskiej XIX wieku, red. J. B a c hó r z, A. Kow a lcz y k ow a, Wroclaw 2009, s. 733, Vademecum Polonisty.

343 Ibidem.

${ }^{3+1}$ M. Roll e, Ateny wolyńskie. Szkic z dziejów oświaty w Polsce, Lwów 1923, s. 123.

315 J. Korzeniow ski, Kurs poezyi, Warszawa 1829, s. 199.

3th Ibidem, s. 200. 
wieloszczegółowe” o większych rozmiarach i „bardziej rozmaitej materii". Podobną opinię wygłaszał wiele lat później w 1838 roku Józef Kraszewski, zaznaczając, że "powieść uważamy za zmniejszony romans" ${ }^{347}$. Granice między tymi terminami były bardzo płynne. Jak zauważa Antonina Bartoszewicz, powieść w krytyce literackiej pierwszej połowy XIX wieku często występowała jako synonim dzisiejszych terminów, takich jak narracja, wątek oraz fabuła ${ }^{348}$. Tym ostatnim znaczeniem posługiwał się także Korzeniowski w swoich pismach ${ }^{349}$.

Należy podkreślić również, że w okresie międzypowstaniowym nazwa „powieść" dominowała w podtytułach dzieł wraz z dookreśleniami, na przykład: Mnich. Powieść wschodnia, Hugo. Powieść krzyżacka, Grażyna. Powieść litewska, czy Maria. Powieść ukrainska. Jednak bardzo rzadko pojawiał się epitet „poetyczna", a zatem trudno było na podstawie samych nagłówków stwierdzić, czy dzieło napisane jest wierszem, czy też prozą. Zatem, jak konkluduje Bartoszewicz, powieść była wyznacznikiem fabularności, a podtytuł - zakresu tematycznego ${ }^{350}$. Jednak Jakubowski, podobnie jak Seweryn Goszczyński w Zamku kaniowskim, nie zdecydował się na sprecyzowanie odmiany powieści. O tym, że postrzegał Majora Aleksandra jako utwór narracyjny, świadczyć może analiza rękopisu, gdyż trzeci rozdział dzieła pierwotnie nosił tytuł Powieść starego Tomasza, który jednak Rosienkiewicz przekreślił i zdecydował się zastąpić słowem: „opowieść”. Jednak otwartą kwestią pozostaje wierność przekładu. Na uwagę zasługuje fakt, że Adam Mickiewicz, będący dla Jakubowskiego największym autorytetem, posługiwał się terminem „powieść” przede wszystkim jako nazwą gatunku mówionego. Potwierdza to Antonina Bartoszewicz ${ }^{351}$, opierając się na materiałach Stownika języka Mickiewicza. Owa homonimiczność powieści ${ }^{352}$ obecna jest w Konradzie Wallenrodzie ${ }^{353}$, którego August Antoni bardzo cenił, o czym świadczy przetłumaczenie jego fragmentu (notabene Powieści Wajdeloty!) w The Remembrances...

Wydaje się, że w zamierzeniu autora Major Aleksander miał pretendować do tzw. „powieści prawdziwej”. Wskazują na to wypowiedzi narratora, zapewniające czytelnika o autentycznym charakterze świata przedstawionego. Jakubowski nie sięgnął po tak popularne rozwiązania charakterystyczne dla literatury polskiej XIX wieku, jak powołanie się na odnaleziony rękopis czy pamiętnik bohatera (bę-

37 Stownik literatury..., s. 734.

H* A. Bartoszewicz, O glównych terminach $i$ pojęciach w polskiej krytyce literackiej w pierwszej potowie XIX wieku, Warszawa 1973, s. 98, Prace Wydzialu Filologiczno-Filozoficznego / Towarzystwo Naukowe w Toruniu, t. 23, z. 3.

3.9 J. Korzeniowski, op. cit., s. 54.

(5) A. Bartoszewicz, op. cit., s. 107.

151 Ibidem, s. 98.

152 Homonimiczność rzeczownika „powieść” polega na tym, że termin ten byl odnoszony do czasowników: „powiadać” (w znaczeniu oznajmiać) i „opowiadać” (w znaczeniu opowiedzieć się po czyjejśs stronie), por. ibidem, s. 96.

15.1 Byty powieści, ze Halban przebrany,

Litewska piosnke Konradowi spiewat, 
dące sfingowanymi źródłami), ale na bezpośredni kontakt narratora z postaciami, a także wiarygodnymi pośrednikami ${ }^{35.4}$. To właśnie osoba mówiąca staje się "siłą sprawczą", która kreuje świat opowiadania, dokonując selekcji zdobytych informacji dla czytelnika. Narrator nawet na chwilę nie oddaje swojego pola innym postaciom (nie licząc przytaczanych dialogów), potwierdzając swoją uprzywilejowaną pozycję w przekonaniu, że nikt nie zrobi tego lepiej niż on sam. Nie odzwierciedla przy tym inercyjnie naturalnego stanu rzeczy, ale twórczo go przetwarza. Tym samym autor nie maskuje literackiego charakteru powieści, mimo uwydatnienia autentyzmu historii. Tak też dzieje się $w$ rozdziale drugim, kiedy Jakubowski zrezygnował z wprowadzenia elementu gawędy, tłumacząc: „Musimy wziąć na siebie opowiadanie Tomasza, który jako stary wiarus był za rozwlekły i pełen ustępów, porównań itp" 355 . Natomiast opisanie dziejów młodości Aleksandra poprzedził słowami: „Major nigdy o wydarzeniach życia swego nie wspominał, z tego zaś cośmy słyszeli od Tomasza, zbierzmy wszystko, co się dotycze mistycznego życia Majora" 356 .

Nie oznacza to bynajmniej, że twórca niczym w poemacie dygresyjnym czyni swoje „ja” głównym tematem dzieła. W Majorze Aleksandrze narrator dyskretnie ukrywa się za opowiadanymi wydarzeniami, od czasu do czasu tylko ujawnia swoją obecność. Opowiadanie jest tak ukształtowane, że przez opisane wydarzenia prześwieca genetyczna sytuacja narracyjna, realizując typ narracji dwupłaszczyznowej. Osoba mówiąca wypowiada się w trzeciej osobie, wpisując się w powszechną tendencję w literaturze po 1826 roku, będącą efektem oddziaływania walterskotyzmu ${ }^{357}$. Na podstawie zachowanego fragmentu można wywnioskować, że mamy do czynienia z narratorem abstrakcyjnym. Nie ujawnia on bezpośrednio swojej tożsamości, ale relacjonuje wydarzenia $z$ perspektywy naocznego świadka. Z początku można odnieść wrażenie, iż nie posiada on pełnej wiedzy o świecie przedstawionym, śledzi przebieg wypadków wraz z rozwojem akcji na równi z czytelnikiem, a cała sytuacja również dla niego jest zagadkowa. Jednak ograniczenie wiedzy opowiadającego jest pozorne, podmiot mówiący zna całą historię, opowiada ją na nowo ex post, z dystansu czasowego. Dlatego też stwierdzenie, że Aleksander mówił czasami w „jakimś niezrozumiałym języku" ${ }^{358}$, stanowi jedynie zabieg, mający podtrzymać rosnące zaciekawienie czytelnika. Narrator doskonale go rozumie, ujawnia bowiem swoją polską narodowość dwukrotnie: pierwszy raz wspominając o działalności „naszych magnatów” po śmierci Augusta III, później rozwodząc się nad najpiękniejszymi regionami „naszego kraju”. Wypowiada się

3:4 Uwiarygodnieniu historii służyło osadzenie jej na tle prawdziwych wydarzeń historycznych, takich jak kampania egipska Napoleona czy bunt Gonty, a także wspomnienie innych realnych postaci: generala Dessaix, Woltera, Augusta III, Czartoryskiego, Niemcewicza i Konarskiego.

35. A. A. Ja kub ow ski, Pisma pośmiertne..., s. 57.

15ik Ibidem, s. 61.

3.- Ja si ń s k a, Narrator w powieści przedromantycznej: (1776-1831), Warszawa 1965, s. 6, Historia i Teoria Literatury. Studia. Historia Literatury, 15.

1.ik A. A. Ja kubow'ski, Pisma pośmiertne..., s. 54. 
jak człowiek wykształcony, dobrze zorientowany w historii europejskiej, ale też i bardzo wrażliwy.

Jakubowski aktualizuje kategorię czytelnika, traktując go w szczególny sposób. Rzeczywiście, momentami można odnieść wrażenie, iż powieść ta została napisana z myślą o amerykańskim odbiorcy, nieobeznanym w historii Polski. Stąd pojawiają się $w$ utworze parentezy, pełniące funkcje komentarzy wyjaśniających oraz wzmianki o najważniejszych wydarzeniach politycznych, społecznych i filozoficznych w XVIII-wiecznej Europie z naciskiem na Polskę. Retrospekcje sięgają dalej, niż wymaga tego fabuła, autorowi zależy na zarysowaniu tła historycznego, a przy tym na lepszym naświetleniu motywów postępowania bohaterów. Budowanie więzi $z$ odbiorcą przejawia się $\mathrm{w}$ częstym posługiwaniu się przez narratora pierwszą osobą liczby mnogiej oraz pytaniami retorycznymi skierowanymi do adresata. Zabieg ten służy również zaangażowaniu emocjonalnemu czytelnika, stąd odwoływanie się do jego uczuć i przekonań. Pluralis narratora dotyczy również refleksji egzystencjalnych, które traktuje jako wspólne doświadczenie $\mathrm{z}$ odbiorcą. Elementem zacieśniającym relację $\mathrm{z}$ nim jest również posłużenie się zaimkiem dzierżawczym "nasz" w stosunku do Aleksandra. Stwarza to z jednej strony pewną atmosferę poufałości, wspólnoty z odbiorcą i solidaryzowania się z nim, jak również ujawnia pozytywne ustosunkowanie się do bohatera. Narrator, zanim przejdzie do opisania dziejów młodości Aleksandra, daje do zrozumienia, że postawa tytułowej postaci jest mu bliska. Identyfikuje się z nią i bierze w obronę, sugerując, że nie każdy odbiorca jest na tyle wrażliwy, aby wczuć się w jego położenie:

Gdy chciwość i spekulacje zamieszkują zamki, będące niegdyśszlachetnego zapatu siedziba, gdy juz rzadko i pod skromna strzecha, cnota i niewinność przebywaja; jakiegoż wspótczucia spodziewać się można dla naszego bohatera? Zimny czytelnik nazwie go i opowiadacza jego wydarzeń szaleńcem, czulsze serca kobiet dadza im grzeczniejsze nazwiska fantastyków ${ }^{359}$.

W Majorze Aleksandrze uwidacznia się silna inspiracja powieściami poetyckimi George’a Byrona zarówno pod względem kompozycji, jak i kreacji postaci. Dzieło Jakubowskiego odznacza się akcją wierzchołkową o zaburzonej chronologii, fragmentarycznością, a także aurą tajemniczości i niedomówień. Tytułowy bohater od pierwszych kart dzieła nosi rysy bohatera bajronicznego. Dumny, posępny, małomówny, samotny wśród ludzi, których unika, pozostaje dla nich niezrozumiany i niedostępny. Złamany tajemniczym nieszczęściem, jest obojętny na otaczającą go rzeczywistość, gardzi życiem i wszelkimi zaszczytami. Nie boi się śmierci, a postronni obserwatorzy mają wrażenie, że nawet jej szuka. Wyróżnia się przy tym wielką odwagą i męstwem.

W przeciwieństwie do twórczości Byrona z Majora Aleksandra nie wyłania się wizja świata pozbawiona wymiaru soteriologicznego, wizja pustej transcen- 
dencji, a główny bohater nie stawia siebie w roli Absolutu. W Aleksandrze trudno też dopatrzyć się wyrzutów sumienia, piętna popełnionej zbrodni czy pragnienia zemsty albo nienawiści do wrogów. Major to osoba, która straciła wszystko, co miało dla niej jakiekolwiek znaczenie - ojca, ukochaną, przyjaciół i majątek dlatego jest wypalona uczuciowo, nic nie ma już dla niej sensu, bezskutecznie szuka śmierci. Jedynym pocieszeniem, a także łącznikiem z na zawsze utraconą, szczęśliwą przeszłością staje się pies Filaks. Dzisiejszego czytelnika bawić może przedstawiona dość obszernie zażyłość łącząca oficera wojsk napoleońskich i czworonoga. Jednak więź między człowiekiem a zwierzęciem była częstym motywem poematów lorda Byrona, powielanym później w Arabie oraz Mnichu przez Juliusza Słowackiego. Wierny wierzchowiec jawił się w tych utworach jako jedyny sprzymierzeniec i towarzysz wyalienowanej jednostki, podobnie jak Filaks doskonale rozumiejący się ze swoim panem. O wielkim przywiązaniu jeźdźca i rumaka w Arabie najpełniej świadczyło to, że przed śmiercią, gdy bohater snuł wizję upragnionego raju, mówił:

Niech mi tam prorok wróci mego konia,

Który gdzieś w piaskach pustyni spoczywa ${ }^{360}$.

Aleksander natomiast za wszelką cenę chciał ratować psa, który zaginął w czasie bitwy. Ani trochę nie przejmował się odniesionymi ranami oraz tym, że może umrzeć. Wyznaczył dużą nagrodę za odnalezienie Filaksa, co spotkało się z niezrozumieniem, a nawet kpiną otoczenia. Jednak dla Majora:

Filaks byt składem jego przeszlego szczęścia, mitości - byt niejako usobistnieniem wszystkiego - byt wszystkim dla Majora - ostatnim ogniwem tańcucha taczacego go $z$ życiem ${ }^{361}$.

Rozbudowany na początku powieści wątek związany z zaginięciem psa był przemyślanym zabiegiem kompozycyjnym i stanowił pretekst dla niespodziewanego zwrotu akcji oraz częściowego ujawnienia biografii tytułowego bohatera.

Maria Janion widziała główny czynnik odróżniający bohatera bajronicznego od Konrada Wallenroda w tym, że postacie Byrona walczyły jedynie o własną niezależność, czyniąc $z$ innych narzędzie do wykonania prywatnej zemsty ${ }^{362}$. Wobec silnego patriotyzmu Aleksandra, zarysowanego w dalszej części powieści, wydaje się pewne, że młodzieniec dołączył do armii napoleońskiej ${ }^{363}$, gdyż jak większość Polaków widział w tym kroku szansę na odzyskanie przez Polskę niepodległości. W powieści odkryta została motywacja wyprawy do Egiptu Tomasza, gdzie spotkał się z Wojewodzicem:

36) J. S łow a c ki, Powieści poetyckie, oprac. M. Kridl, Wroclaw 1949, s. 85, Biblioteka Narodowa. Seria 1, nr 47.

361 A. A. Ja kubowski, Pisma pośmiertne..., s. 54.

362 Por. M. Ja nion, Tragizm Konrada Wallendroda, [w:] e a de m, Romantyzm. Studia o ideach $i$ stylu, Warszawa 1969, s. 9-48.

${ }^{36.3}$ Fascynacja Napoleonem zostawila swój ślad nie tylko w Majorze Aleksandrze, ale także w jednym $z$ najciekawszych wierszy Jakubowskiego pt. Bonaparte. 
styszat o formujacych się tam legionach, o nadziejach, zwodniczych nadziejach, że Polska powstać miała za sprawa rzeczypospolitej francuskiej. Znalazty te nadzieje przystęp do poczciwego serca Tomasza - $i$ on sie niemi tudzit - bo jeśli każde serce poczciwe, tym więcej samotne serce daje przystęp ztudzeniom ${ }^{364}$.

Komentarz ten zdradza również, że narrator posiada wiedzę człowieka współczesnego, który ustosunkowuje się do określonych faktów z historii. Dlatego też Major, dłużej przebywający w wojsku francuskim, uświadamiał sobie niewielkie prawdopodobieństwo spełnienia swoich marzeń na wyzwolenie ojczyzny, co tylko pogłębiało jego rezygnację:

[Oko jego] byto zimne i obojętne, gdy myślat, że Polska była nie jego, że stużyt jako cudzoziemiec w obcem wojsku i obcej sprawie ${ }^{365}$.

Można mieć nadzieję, że pozostałe fragmenty Majora Aleksandra rzeczywiście powstały i wciąż czekają na swojego znalazcę. Jednak istnieje też prawdopodobieństwo innego scenariusza. Niewykluczone, że Jakubowski postanowił wyprawić się na teren prozy, jednak przerwał swoją pracę $w$ trakcie czwartego rozdziału, zniechęcony efektem i stwierdziwszy, że stanowi to zadanie ponad jego siły. Bardziej prawdopodobne jest założenie, że Jakubowski kontynuował pisanie powieści, z której dalsza część zaginęła. Na podstawie zachowanego fragmentu można przypuszczać, że Major Aleksander jako całość mógł zmierzać do paraboli tragicznego losu jednostki. Utwór zapowiadał się na całkiem udaną nowelizację powieści poetyckiej.

Nie wydaje się, aby w zamierzeniu autora Major Aleksander miał być jedynie powiastką, choć nie można tego zupełnie wykluczyć. W języku krytyki literackiej XIX wieku powiastka była bardzo zbliżona do dzisiejszego opowiadania, oznaczała krótki utwór o błahej tematyce ${ }^{366}$. Jakubowski był młodzieńcem o wielkich ambicjach i możliwościach. Miał również w planach stworzenie epopei narodowej Bunty Chmielnickiego, z której zachował się imponujący fragment. Czy zatem powiastka mogła być w centrum zainteresowań „młodego orła, który sił swoich próbował" ${ }^{367}$ ? Z drugiej strony należy podkreślić, że Jakubowski dopiero rozpoczynał nowy etap w swojej twórczości, zorientowany na amerykańskiego odbiorcę, stąd mógł doskonalić własny warsztat od form prostszych do bardziej skomplikowanych. Przemawia za tym fakt, że również we Wspomnieniach polskiego wygnańca jeden z nielicznych autorskich utworów Jakubowskiego jest właśnie powiastką prozaiczna - The Polish Lovers.

36 A. A. Jakubowski, Pisma pośmiertne..., s. 60.

365 Ibidem.

36 A. B artoszewicz, op. cit., s. 96.

367 A. A. Jakub ow ski, Pisma pośmiertne..., s. 64. 



\section{Zakończenie}

Twórczość Augusta Antoniego Jakubowskiego jest skromna ilościowo, lecz bogata oraz zróżnicowana zarówno pod względem tematycznym, jak i formalnym. Dorobek literacki syna Malczewskiego lączy się nierozerwalnie $\mathrm{z}$ jego tragiczną biografią, która sprawiła, że w ciągu zaledwie czterech lat od opuszczenia ojczyzny młody wygnaniec chcący „śpiewać pieśń nieśmierelności” zamienił się w umarłego za życia „upiora", pragnącego na zawsze opuścić świat, który zdradził jego marzenia. Na przyspieszone dojrzewanie do śmierci niewątpliwie wpłynęło w pierwszej kolejności przedłużające się zamknięcie po aresztowaniu, gdy nie miał nadziei na poprawę losu, jak również oddzielenie go od ojczyzny i ukochanej matki, którą odzyskał w niespodziewany sposób, a zaraz potem utracił. Mocno na jego psychice odcisnęła się długa i niebezpieczna podróż do Ameryki, przypominająca żeglugę łodzią Charona do nicości. Także pobyt w miejscu wygnania i osamotnienia, gdzie nie udało mu się zakorzenić i znaleźć nowych wartości, pogłębił tylko jego depresję i wrodzoną skłonność do melancholii. Jakubowski nie był w stanie uwolnić się w Ameryce od obrazu Podola i nie przestawał za nim tęsknić. Nawet w utworach egzotycznych, dotyczących kultury indiańskiej, August Antoni umieszczał zaszyfrowany wizerunek ukochanej ojczyzny, której tak bardzo mu brakowało. Chociaż w kilku wierszach zatytułowanych Pożegnanie próbował rozstać się z przeszłością, nie mógł zamknąć tego etapu życia i rozpocząć nowego. To właśnie wspomnienia, pełniące na początku funkcję konsolacyjną ${ }^{368}$, szybko stały się źródłem największego cierpienia, trudnego do wysłowienia, czego świadectwo zawarł Jakubowski w swoich wierszach, jak również w przedmowie do The Remembrances...

Alina Witkowska podkreślała, że utwory syna Malczewskiego reprezentują "prawdziwie czarny romantyzm" i wyróżniaja się "zastanawiająco jednolitą barwą uczuciową: [są] pesymistyczne, posępne, gorzkie"369. Również Jarosław Ławski zaznaczał, że wspólnym pniem liryków młodego wygnańca jest właśnie pesymizm ${ }^{370}$. Jednak twórczość poetycka, stanowiąca prywatny „pamiętnik duszy" Jakubowskiego, była przeznaczona tylko dla niego, stąd świat zapamiętał go jako "młodego filozofa", który zawsze pocieszał innych i był powszechnie lubiany. W The Remembrances of a Polish Exile Jakubowski jawi się jako reprezentant

\footnotetext{
${ }^{36 *}$ Por. wiersz Wspomnienie i nadzieja.

s69 A. Witkowska, Romantyzm, „Rocznik Literacki” 1973, s. 261.

171) J. Ławski, Tragiczna $i$ utracona..., s. 224.
} 
gnębionego, ale niezłamanego narodu, który wciąż ma nadzieję na odzyskanie niepodległości. Mimo fatalizmu losu Polaków, zmuszonych ciągle odpierać ataki nieprzyjaciela, August Antoni nie przejawiał rozpaczy, tak charakterystycznej dla jego wierszy, ale bunt i chęć zemsty. Najpełniej wyraża się to w słowach:

Tak więc nasza ojczyzna nie może zginać. Tyle chwaty spoczywa wokót jej imienia, taki duch poświęcenia żyje w niej, jej język wzbogacony o poezję i pieśni - to wszystko mówi nam, że będzie jeszcze istnieć. I mamy nadzieję, że te utwory pomoga w przebudzeniu $i$ w przyszłości ustyszymy dźwięk jej zemsty i zbawienia. Niech tak się stanie ${ }^{3 i !}$.

August Antoni mimo osiągniętej wysokiej dojrzałości twórczej jak na swój młody wiek, cały czas poszukiwał nowych form i środków wyrazu. „Młody orzeł sił swoich próbował" ${ }^{372}$ w języku angielskim, który opanował niezwykle szybko. Jako pierwszy Polak w Ameryce w The Remembrances of a Polish Exile napisał nie tylko eseje o polskiej historii, kulturze, literaturze i edukacji oraz dokonał przekładów poezji romantycznych. Sam również tworzył własne utwory w obcym języku, czego przykładem jest patriotyczna powiastka prozatorska The Polish Lovers, a także tłumaczył swoje wiersze napisane wcześniej po polsku.

Zachowany fragment Majora Aleksandra również świadczy o dużych ambicjach Jakubowskiego. Jako całość najprawdopodobniej zmierzał do paraboli tragicznego losu jednostki. Zapowiadał się na całkiem udaną nowelizację powieści poetyckiej. Powieść tę August Antoni nie tylko nasycił pesymizmem Marii, ale potrafił też utkać $w$ niej misterną sieć intertekstualnych nawiązań do poematu ojca. Utwór ten po raz kolejny dowodzi, że dzieło pisane w języku angielskim z myślą o zagranicznym czytelniku nie mogło powstać bez odwołań do wzorców, na których wychował się Jakubowski oraz wartości patriotycznych, jakie cechowały całą jego twórczość.

Podążanie śladami życia i twórczości Augusta Antoniego to niezwykle fascynująca przygoda, która ciągle trwa. Pozostaje jeszcze wiele wątków do zbadania. Być może kolejne utwory polskiego wygnańca przez chwilę popularnego w Ameryce wciąż czekają na swojego odkrywcę. Pisanie monografii Augusta Antoniego Jakubowskiego stało się pasjonującym śledztwem, prowadzonym na dwóch kontynentach. Analiza silnie autobiograficznej twórczości Jakubowskiego i odnajdywanie różnych jej kontekstów nie byłoby możliwe bez wsparcia i sugestii Bogusława Doparta. Odkrywanie coraz to nowych dokumentów i śladów zapomnianego polskiego poety, który w wieku 21 lat zakończył swoje życie, urzeczywistniło się dzięki nieocenionej pomocy i życzliwości mecenasa Przemysława Jana Blocha z Nowego Jorku. Wydaje się, że teraz lepiej rozumiemy osobowość poety, który w chwili rozkwitu swojej kariery literackiej popełnił samobójstwo. Można mieć nadzieję, że także inne tajemnice związane z życiem i twórczością syna Malczewskiego, które wydają się być bez odpowiedzi, wkrótce zostaną odkryte. 


\section{Bibliografia}

\section{Bibliografia podmiotu:}

Jakubowski A. A., Pisma pośmiertne, red. M. Rosienkiewicz, Paryż 1839.

Jakubowski A. A., Poezje, wstęp i red. J. Maślanka, Kraków 1973.

Jakubowski A. A., The Remembrances of a Polish Exile, Philadelphia 1836.

Jakubowski A. A., The Remembrances of a Polish Exile. Wydanie posko-angielskie, przekł., wstęp, red. J. Lawski, P. Oczko, Białystok 2013.

\section{Bibliografia przedmiotu:}

Alvarez A., Bóg Bestia. Studium samobójstwa, tłum. Ł. Sommer, Warszawa 1997.

Andrzejewski J., Z dnia na dzień, „Literatura” 1973, nr 48.

Antoni Malczewski, jego żywot i pisma ozdobione popiersiem, red. A. Bielowski, Lwów 1843.

Bachelard G., Wyobrażnia poetycka. Wybór pism, tłum. H. Chudak, A Tatarkiewicz, tłum. J. Bloński, Warszawa 1975, Biblioteka Krytyki Wspótczesnej.

Bartoszewicz A., O glównych terminach i pojęciach w polskiej krytyce literackiej w pierwszej połowie XIX wieku, Warszawa 1973, Prace Wydziatu Filologiczno-Filozoficznego / Towarzystwo Naukowe w Toruniu, t. 23, z. 3.

Bartoszyński K., Powieść w świecie literackości. Szkice, Warszawa 1991.

Bentkowski F., Historya literatury polskiey wystawiona w spisie dziet drukiem ogtoszonych przez Felixa Bentkowskiego, t. 1, Warszawa-Wilno 1814.

Antoni Malczewski, jego żywot i pisma ozdobione popiersiem, wyd. A. Bielowski, Lwów 1843.

Brzozowski J., Odczytywanie Romantyków (2). Dwadzieścia dwa szkice i notatki o Mickiewiczu, Stowackim i Norwidzie, Poznań 2011, Seria Filologia Polska / Uniwersytet im. Adama Mickiewicza w Poznaniu, nr 126.

Cedro A., Numa Lepkowski i historia nieznanej dedykacji Norwida, „Studia Norwidiana” 2011, nr 29.

Chmielowski P., Józef Korzeniowski, jego życie i działalność literacka. Zarys biograficzny, Petersburg 1898, Zyciorysy Stawnych Polaków, nr. 3.

Czerwiński E. J., August Antoni Jakubowski, „Poezje”, „Books Abroad. An International Literary Quarterly" Vol. 49, No. 2.

„Daily Hampshire Gazette”, 26 IV 1837.

Dernalowicz M., Antoni Malczewski, Warszawa 1967, Ludzie Żywi, 13.

Dębicki Z., Syn Malczewskiego, „Kurier Warszawski” 1930, nr 93.

Dopart B., Romantyzm polski. Pluralizm prądów i synkretyzm dzieła, Kraków 1999.

English T. D., The Poetry of Poland, „The Gentleman's Magazine”, ed. W. E. Burton, vol. III, from July to December, Philadelphia 1838.

Gacowa H., „Maria” i Antoni Malczewski. Kompendium źródłowe, przed. J. Maciejewski, Wrocław 1974, Materialy Literackie, 1.

Gaszyński K., Kilka nowych szczegótów o Antonim Malczewskim, „Czas” 1856, nr 68.

Giergielewicz M., August Antoni Jakubowski and his 'Remembrances of a Polish Exile', „The Polish Review" 1971, Vol. 16, No. 2, s. 67-89. 
Goslawski M., Wybór poezji, red. J. Lyszczyna, Katowice 2005, Prace Naukowe Uniwersytetu Śląskiego w Katowicach, nr 2309.

Goszczyński S., Wstęp, [w:] A. Malczewski, Maria, Lipsk 1844.

Goszczyński S., Zamek kaniowski, Kraków 2004.

Grzeloński B., Polacy w Stanach Zjednoczonych Ameryki 1776-1865, Warszawa 1976.

Haiman M., Polacy w Ameryce. Historia wychodźst wa polskiego w Stanach Zjednoczonych, Chicago 1930.

Haiman M., Slady polskie w Ameryce, Chicago 1938.

Holbrook J. M., Webster, Massachusetts, vital records to 1850, Oxford 1980.

Inscriptions on the Grave Stones in the Grave Yards of Northampton and of other towns in the Valley of Connecticut, transl. T. Bridgman, Northampton, Massachusetts 1850.

Iwaszkiewicz J., Zapomniani, "Życie Warszawy" 1974, nr 11.

Jakubowski August Antoni, [hasło w:] Estreicher K., Bibliografia polska, [on-line:] http://www.estreicher.uj.edu.pl/xixwieku/indeks/71450.html - 1 V 2013.

Jeglińska E., Literatura polska w Stanach Zjednoczonych w latach trzydziestych XIX wieku. Krakowskie perspektywy emigracji popowstaniowej, [w:] Literatura polska w swiecie, red. R. Cudak, t. 1, Zagadnienia recepcji i odbioru, Katowice 2005.

Janion M., Romantyzm. Studia o ideach i stylu, Warszawa 1969.

Januszewski T., Z życia Antoniego Malczewskiego, „Dziennik Literacki” 1852, nr 4.

Jasińska M., Narrator w powieści przedromantycznej. (1776-1831), Warszawa 1965, Historia i Teoria Literatury. Studia. Historia Literatury, 15.

Juźwikiewicz J., Polacy w Ameryce, czyli pamiętnik piętnastomiesięcznego pobytu, Paryż 1836.

Kawyn S., Mickiewicz w oczach swoich wspótczesnych. Studia i szkice, Kraków 1967.

Korzeniowski J., Kurs poezyi, Warszawa 1829.

Kowalczykowa A., Pejzaż romantyczny, Kraków 1982

Kowalska A., John Bowring. Ttumacz i propagator literatury polskiej w Anglii, Łódź 1965, Prace Wydziału I Jezykoznawstwa, Nauki o Literaturze i Filozofii - Lódzkie Towarzystwo Naukowe, nr 62.

Kozieradzki A., Wspomnienia z lat szkolnych 1320-1831, Wrocław 1962.

Kracicki l., Zbiór potrzebniejszych wiadomości, porządkiem alfabetu ułożonych, t. 2, Warszawa, Lwów 1781.

Krasiński Z., Dzieła literackie, t. 3, red. P. Hertz, Warszawa 1973, Biblioteka Poezji i Prozy.

„Kronika Emigracji Polskiej”, vol. 5-6, Paryż 1835.

Krosnowski A., Almanach historique de l'Emigration Polonais, Paris 1837.

Krukowska H., Ciemna strona istnienia w romantycznym poemacie Malczewskiego, [w:] A. Malczewski, Maria. Powieść ukraińska, wstęp H. Krukowska, J. Ławski, Białystok 2002, Czarny Romantyzm.

Krukowska H., Nocna strona romantyzmu, [w:] Problemy polskiego romantyzmu, red. M. Żmigrodzka, Wrocław 1974.

Krzyżanowski J., Syn Malczewskiego, [w:] J. Krzyżanowski, W świecie romantycznym, Kraków 1961, Biblioteka Studiów Literackich.

Kunaszowski O. H., Życiorysy uczestników Powstania Listopadowego zebrane na pamiątkę obchodu jubileuszowego pię́dziesięcioletniej rocznicy tego powstania, Lwów 1880.

Lachowicz T., Weterani polscy w Ameryce do 1939 roku, Warszawa 2002, [on-line:] http://dx.doi. org/10.15290/sp.2003.13.18.

Lelewel J., List do putkownika Feliksa Breańskiego, [w:] Listy emigracyjne, t. 1, 1831-1835 (Nry 1-289), wstęp i red. H. Więckowska, Kraków 1948, Wydawnictwa Komisji Historycznej / Polska Akademia Umiejętności, nr 87.

Lerski J. J., Amerykański dziennik majora Hordyńskiego, „Kultura” 1955, nr 98/12.

Lerski J.J., A Polish chapter in Jacksonian America. The United States and the Polish exiles of 1831, Madison 1958, Poland's Millennium Series of the Kościuszko Foundation.

List do A. Cieszkowskiego, [w:] C. Norwid, Pisma wszystkie, t. 10, red. J. W. Goumulicki, Warszawa 1971 . 
List M. Rosienkiewicza do K. Lacha Szyrmy z 9.05.1836, „Kronika Emigracji Polskiej”, t. 6, Paryż 1837.

Longfellow H. W., Pieśn o Hajawacie, tłum. R. Jackow, Wrocław 1960.

Lawski J., Bo na tym świecie Śmierć. Studia o czarnym romantyzmie, Gdańsk 2008, Wokót Literatury - Stowo/Obraz Terytoria, t. 2.

Lawski J., Malczewski - iluminacje i klęski melancholijnego wędrowca, [w:] A. Malczewski, Maria. Powieść ukraińska, Białystok 2002, Czarny Romantyzm.

Lawski J., Siedem. O Auguście Antonim Jakubowskim, [w:] Nihilizm i historia. Studia z literatury XIX i XX wieku, red. M. Sokołowski, J. Lawski, Bialystok-Warszawa 2009, Czarny Romantyzm.

Lawski J., To zawsze wielki człowiek, kto największy z ludzi? (Napoleon, Malczewski, Jakubowski), [w:] Literatura - Pamięć - Kultura. Prace ofiarowane Profesor Elżbiecie Feliksiak, red. E. Sidoruk, M. Leś, Białystok 2010.

Lawski J., Tragiczna i utracona - Ukraina w liryce Augusta Antoniego Jakubowskiego, [w:] „Szkola ukrainska" w romantyzmie polskim, red. S. Makowski, U. Makowska, M. Nesteruk, Warszawa 2012.

Lawski J., W romantycznym „mroku gwiazd". Wyobraźnia katastroficzna Augusta Antoniego Jakubowskiego, [w:] Poezja i astronomia, red. B. Burdziej, G. Halkiewicz-Sojak, Toruń 2006.

Malczewski A., Maria, Sanok 1855.

Malczewski A., Maria. Powieść ukraińska, red. R. Przybylski, Warszawa 1960.

Maślanka J., Poeta tragiczny. (Losy i twórczość A. A. Jakubowskiego), "Ruch Literacki” R. XIII, 1972, z. 5.

Maślanka J., Z dziejów literatury i kultury, Kraków 2001.

McGovern J. R., Yankee Family, New Orleans 2010.

Mickiewicz A., Dziady częś́ III, [w:] A. Mickiewicz, Utwory dramatyczne, red. S. Pigoń, tlum. A. Górski, Warszawa 1982.

Mickiewicz A., Dzieła. Proza artystyczna i pisma krytyczne, t. 5, Warszawa 1997, Dzieła.

Mickiewicz A., Konrad Wallenrod, Gdańsk 2000.

Mickiewicz A., Literatura stowiańska. Wyklady w College de France. Kurs drugi, Warszawa 1935.

Mickiewicz A., Wiersze, red. Cz. Zgorzelski, Warszawa 1982.

Mickiewicz A., Z wykladu XXX (kurs drugi), Z wykladu III (kurs trzeci), [w:] A. Mickiewicz, Prelekcje paryskie, t. 2, red. J. Błoński, Kraków 1997, Biblioteka Polska.

Mochnacki M., Rozprawy literackie, red. M. Strzyżewski, Wrocław 2004, Skarby Biblioteki Narodowej.

Nalepa M., Noc mnie okryla w swoje skrzydla ukirzone, Żyć bez ojczyzny w obcym panowaniu..., Pielgrzym, wygnaniec $i$ „przychodzieñ", [w:] M. Nalepa, Między żarliwościg̨ a zdradą. Studia i szkice o literaturze póżnego polskiego oświecenia, Kraków 2010, Biblioteka Badań nad Oświeceniem, $\mathrm{nr} 7$.

Nekrolog A. A. Jakubowskiego, "Młoda Polska" 1838, nr 25.

Pauszer-Klonowska G., Pani na Pulawach. Opowieść o Izabeli z Flemmingów Czartoryskiej, Warszawa 1978.

Pigoń S., Studia literackie, Kraków 1951, Literatura, Sztuka, Krytyka, nr 16.

Pigoń S., Syn Malczewskiego, „Ruch Literacki” 1930, nr 3.

Piwińska M., Miłość romantyczna, Kraków 1984, Biblioteka Romantyczna.

Podhorski-Okolów L. Do artykulu „Syn Malczewskiego”, „Ruch Literacki” 1931, nr 7.

Podróże i rozprawy literackie. Dzieła zbiorowe Seweryna Goszczyńskiego, t. 3, red. Z. Wasilewski, Lwów 1910.

Polanowski T., A. A. Jakubowski: „Poezje”, „Tygodnik Powszechny” 1974, nr 10.

Polski Stownik Biograficzny, t. 10, red. nacz. K. Lepszy, Wroclaw 1962.

Polski Stownik Biograficzny, t. 19, red. W. Machowski, Wrocław 1974.

Potrykowski J., Martyrologium polskie 1832-1854, rękopis z Biblioteki Książąt Czartoryskich, sygn. 53511 .

Praz M., Zmysly, śmierć $i$ diabet $w$ literaturze romantycznej, tłum. K. Żaboklicki, wstęp M. Brahmer, Warszawa 1974. 
Rolle A. J., Rodzina Malczewskiego, 2010, Klasyka [e-book].

Rolle M., Ateny wolyńskie. Szkic $z$ dziejów oświaty w Polsce, Lwów 1923.

Rosienkiewicz M., [Nekrolog A. A Jakubowskiego], „Młoda Polska” 1838, nr 25.

Rosienkiewicz M., Wiadomość biograficzna o Antonim Auguście Jakubowskim, [w:] A. A. Jakubowski, Poezje, wstęp i red. J. Maślanka, Kraków 1973.

Sawicki S., Początki syntezy historycznoliterackiej w Polsce. O sposobach syntetycznego ujmowania literatury w 1 polowie w. XIX, Warszawa 1969.

Siemieński L., Kilka myśli o Antonim Malczewskim i jego „Marii”, „Przegląd Lwowski” 1872, t. 4.

Sobolewski P., Poets and Poetry of Poland. A collection of Polish verse, including a short account of the history of Polish poetry, with sixty biographical sketches of Poland's poets and specimens of their composition, Chicago 1881.

Slowacki J., Powieści poetyckie, red. M. Kridl, Wrocław 1949, Biblioteka Narodowa. Seria 1, nr 47.

Slownik biograficzny oficerów powstania listopadowego, red. R. Bielecki, t. 2, Warszawa 1995.

Stownik literatury polskiej XIX wieku, red. J. Bachórz, A. Kowalczykowa, Wrocław 2009, Vademecum Polonisty.

Sprague W. B., A sermon preached in the second presbyterian church, Albany, Sabbath Evenining, May 11, 1834. And repeated, by special request, on the ensuing Tuesday evening, in the second reformed dutch church, In behalf of the Polish Exiles lately arrived in this country, Albany, 1834.

Stasik F., Polska emigracja polityczna w Stanach Zjednoczonych Ameryki 1831-1864, Warszawa 1973.

Szturc W., O obrotach sfer romantycznych. Studia o ideach i wyobraźni, Bydgoszcz 1997.

Szydłowska-Brykczyńska W., Egzystencjalistyczne królestwo albo romantyzm na wygnaniu, Chotomów 1991.

Trembecki S., Sofijówka, Kraków 2002, Klasyka Mniej Znana.

Tutinas J., August Antoni Jakubowski - zapomniany poeta romantyczny, „Nowe Książki” 1974, $\mathrm{nr} 4$.

Tuwim J., Ksiega wierszy polskich, t. 1, Warszawa 1956.

Tyszyński A., O szkolach poezji polskiej, [w:] A. Tyszyński, Amerykanka w Polsce. Romans, cz. II, St. Petersburg 1837.

Wardziński Z., English Publications of Polish Exiles in the United States: 1808-1897, „The Polish Review" 1995, No. 4.

Winter N. O., Poland of To-Day and Yesterday. A Review of its History, Past and Present, and of the Causes which Resulted in its Partition, Together with a Survey of its Social, Political, and Economic Conditions To-Day, Boston 1913.

Witkowska A., Romantyzm, „Rocznik Literacki” 1973.

Witwicki S., Wieczory Pielgrzyma. Rozmaitości moralne, literackie i polityczne, t. 1, Lipsk 1866, Biblioteka Pisarzy Polskich, nr 38.

Załuski K., Wspomnienia o Rodzinie Załuskich w XIX stuleciu, Kraków 1907.

Żmigrodzka M., Dwa oblicza wczesnego romantyzmu (Mickiewicz - Malczewski), „Pamiętnik Literacki" 1970 , z. 1.

Żuk E., "The Remembrances of a Polish Exile” Augusta Antoniego Jakubowskiego, "Ruch Literacki” 1979, z. 5. 


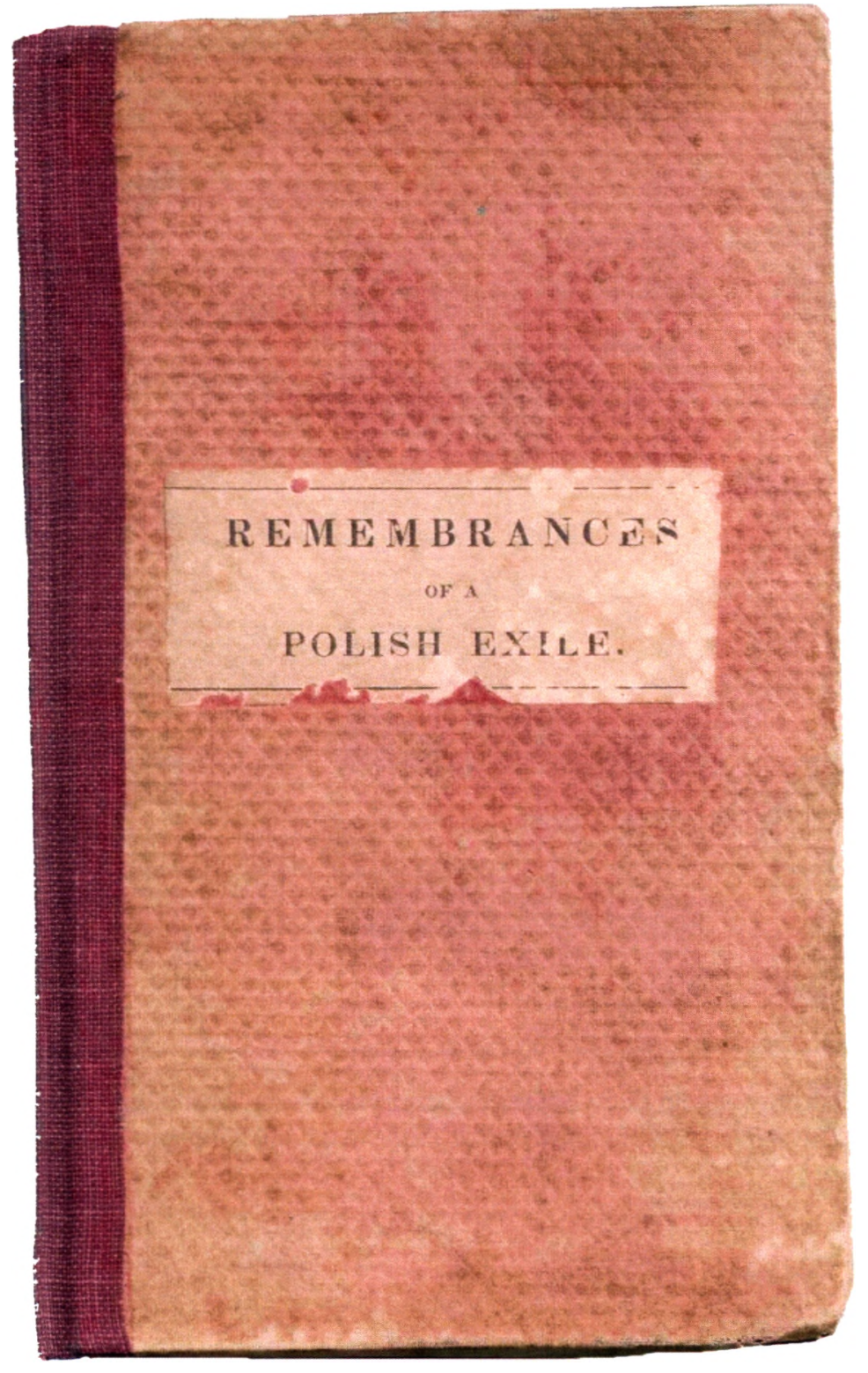

1. The Remembrances of a Polish Exile w edycji Adama Waldiego (Philadelphia 1835) z kolekcji Fundacji Rodzinnej Blochów. Wewnątrz tego egzemplarza znajduje się dedykacja dla Lucy E. Dewey oraz wiersz Podolia's Exiled Child Julii Bowers 


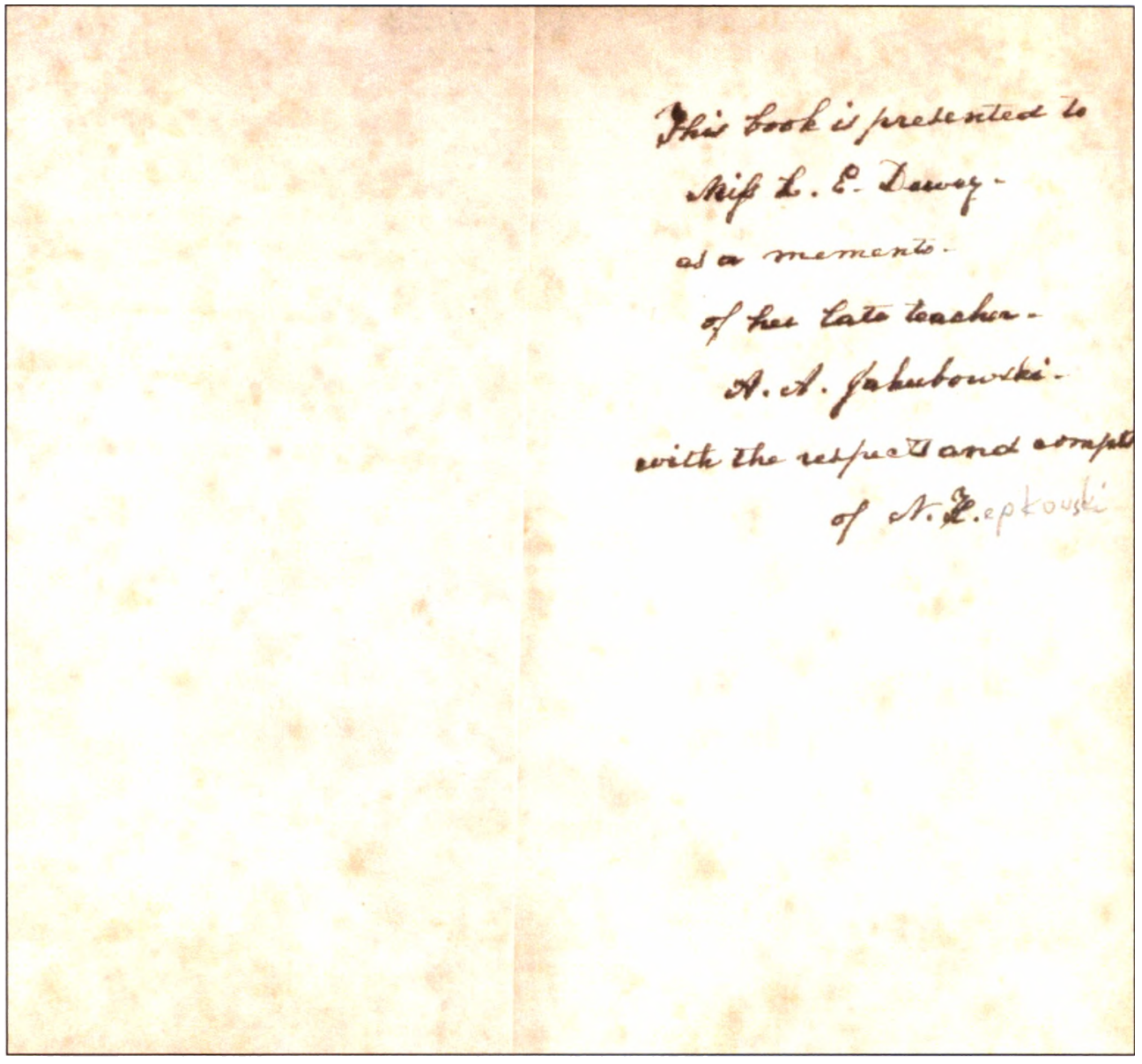

2. Dedykacja adresowana do Lucy E. Dewey przez Napoleona Kościałkowskiego na kartach egzemplarza The Remembrances of a Polish Exile w edycji Waldiego (Philadelphia 1835) 
If ar from where thoses his seatice eose, And dearest kindred bnile, the pare portects in encet epose, oodolia's exilud chilet.

So the welley sock he fore kise.

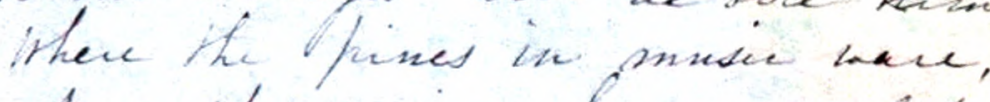
And the eremeng bruges wafled, ler th Dotish exilesgrave

And in this soutthel beanty Sithe a cheasm he pasped anays Lite the eaving flighter fqupes Wit in the vesper taily $l$, then the ex mines 2ephes high in thing of tiat sadpated one. so eavly dorment to die. Hut one tike a toud by then stard wer hid dying beds To bear to his civolut mather The Eiding, he dead

3. Wiersz Julii Bowers poświęcony pamięci Jakubowskiego, zatytułowany Podolia's Exiled Child, wklejony na okładce The Remembrances of a Polish Exile z edycji Waldiego (Philadelphia 1835) 

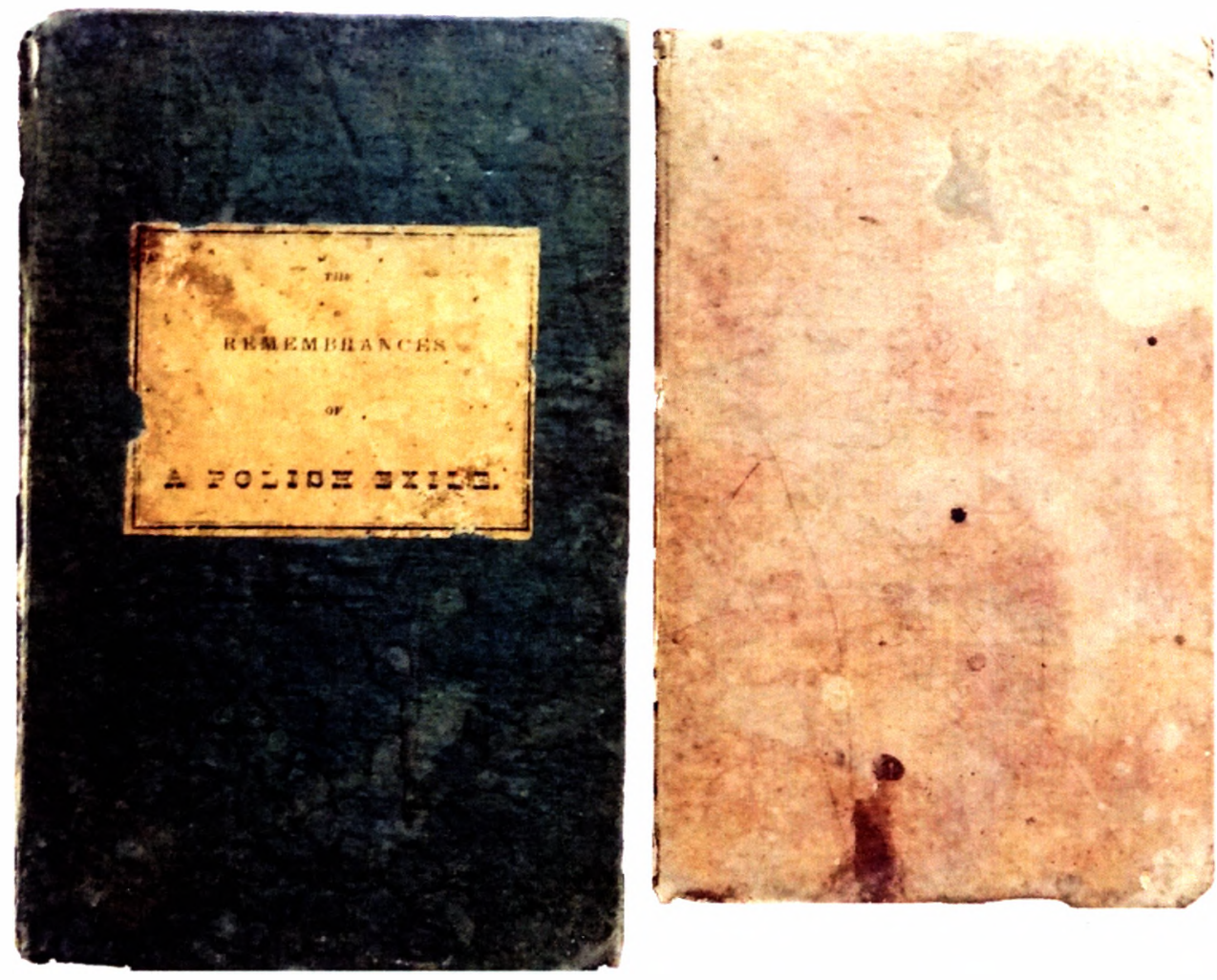

4. Dwa egzemplarze The Remembrances of a Polish Exile z prestiżowego wydania Colgera Shermana w dwóch wariantach okładek (Philadelphia: Albany 1835), pochodzące z kolekcji Fundacji Rodzinnej Blochów 


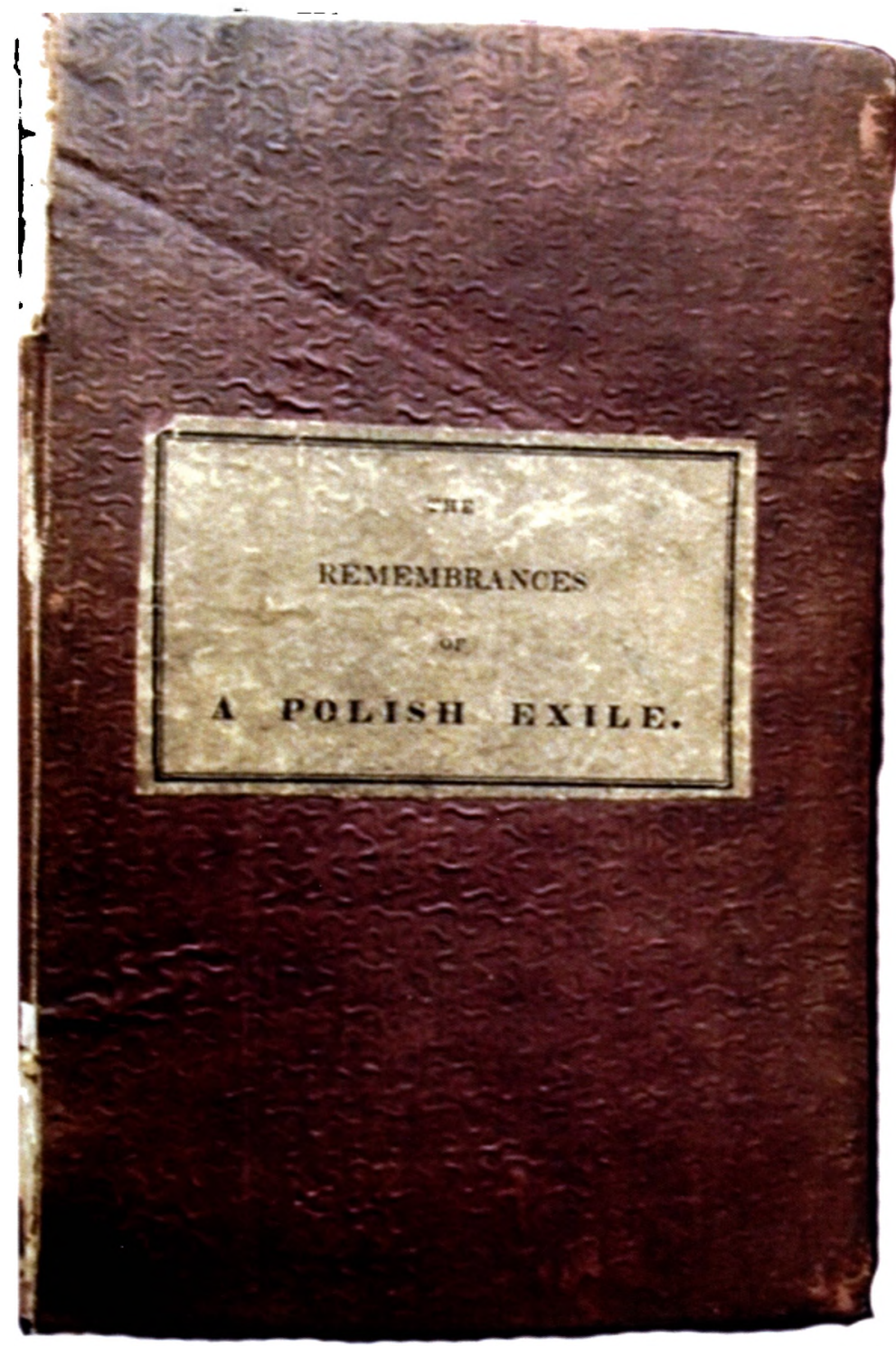

5. Okładka The Remembrances of a Polish Exile z edycji Haswell and Fleu (Philadelphia: Albany 1836) z kolekcji Fundacji Rodzinnej Blochów 


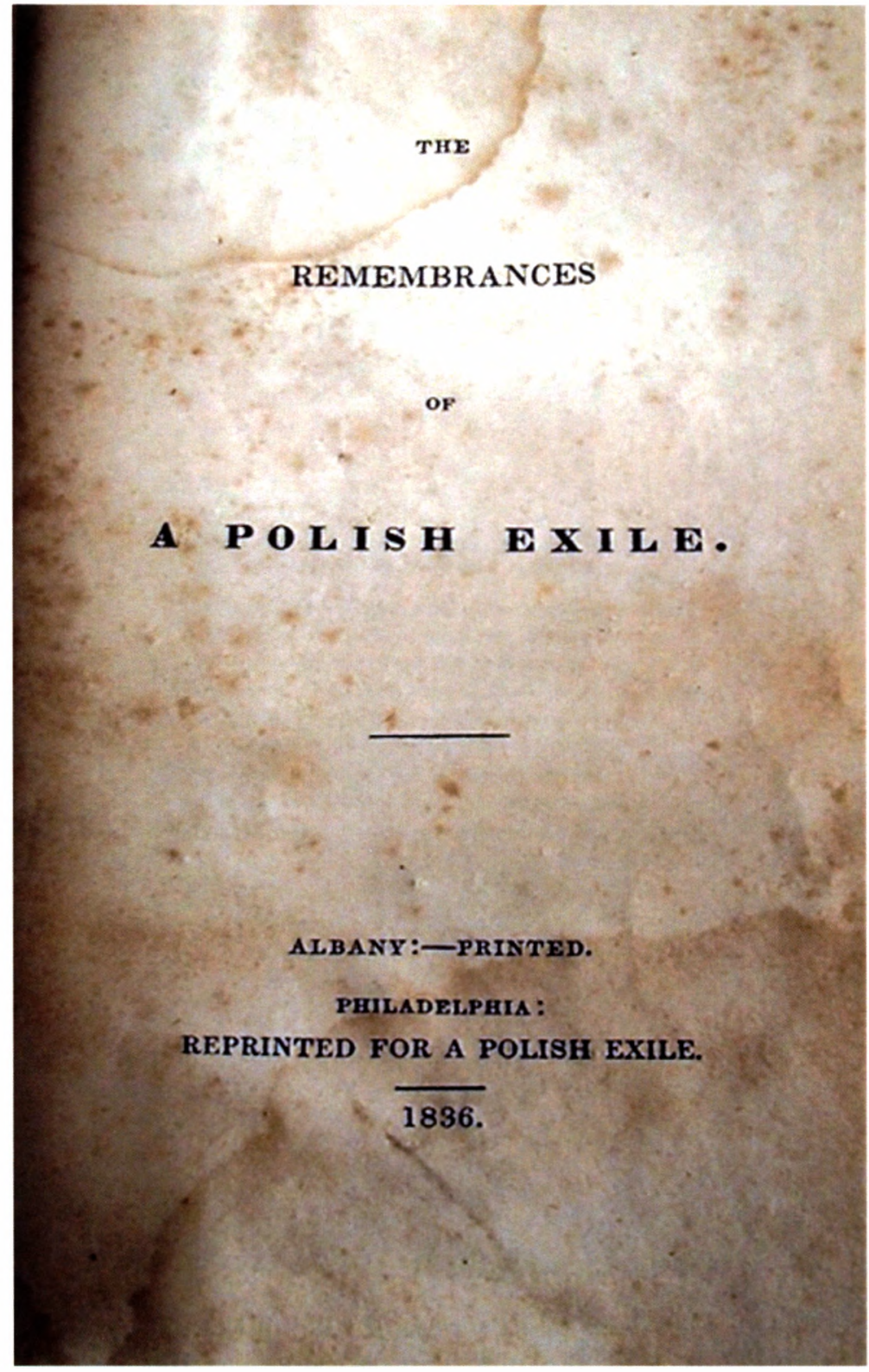

6. Strona tytułowa The Remembrances of a Polish Exile z edycji Haswell and Fleu (Philadelphia: Albany 1836) ze zbiorów Fundacji Rodzinnej Blochów 

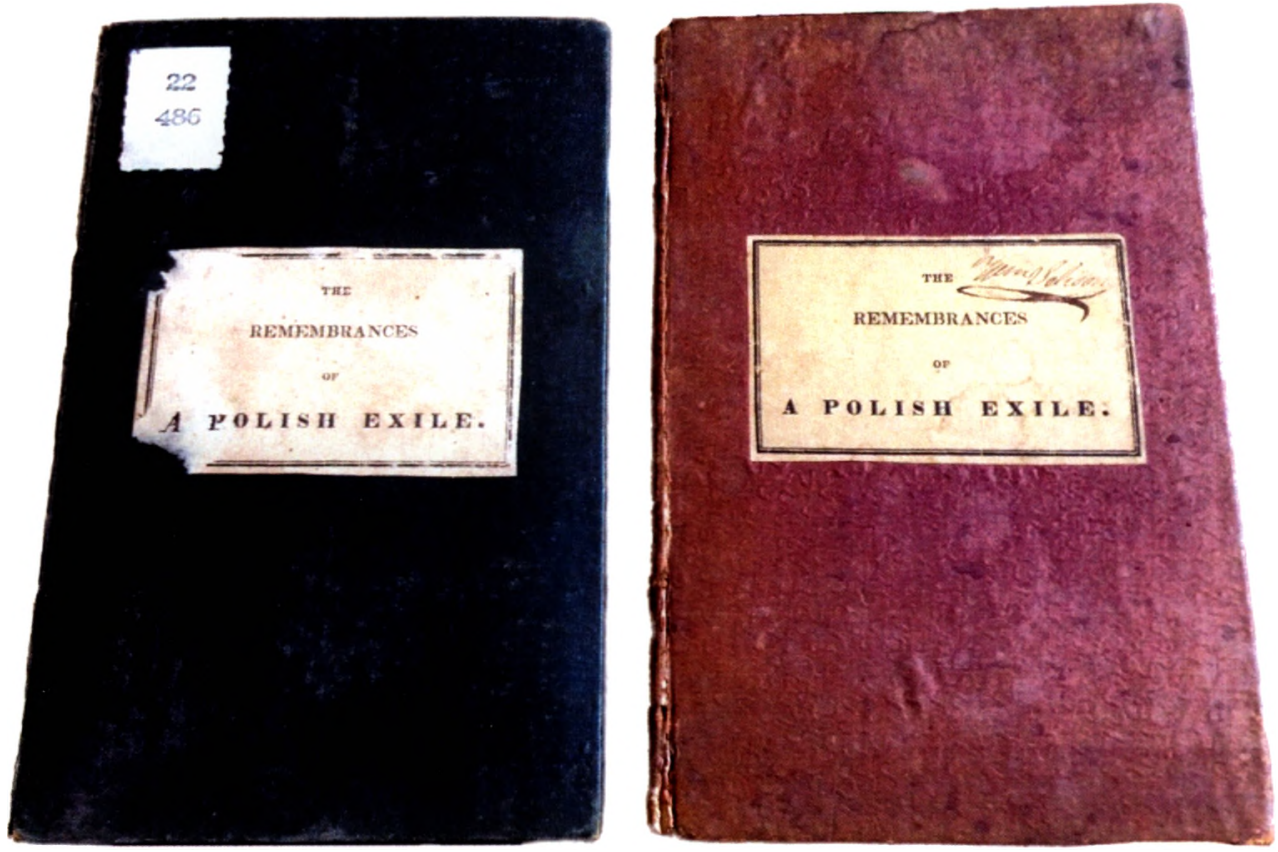

7. Ostatnie wznowienie The Remembrances of a Polish Exile za życia Jakubowskiego (Dwa warianty wydania Haswell and Fleu Printers. Philadelphia: Albany 1836) z kolekcji Fundacji Rodzinnej Blochów

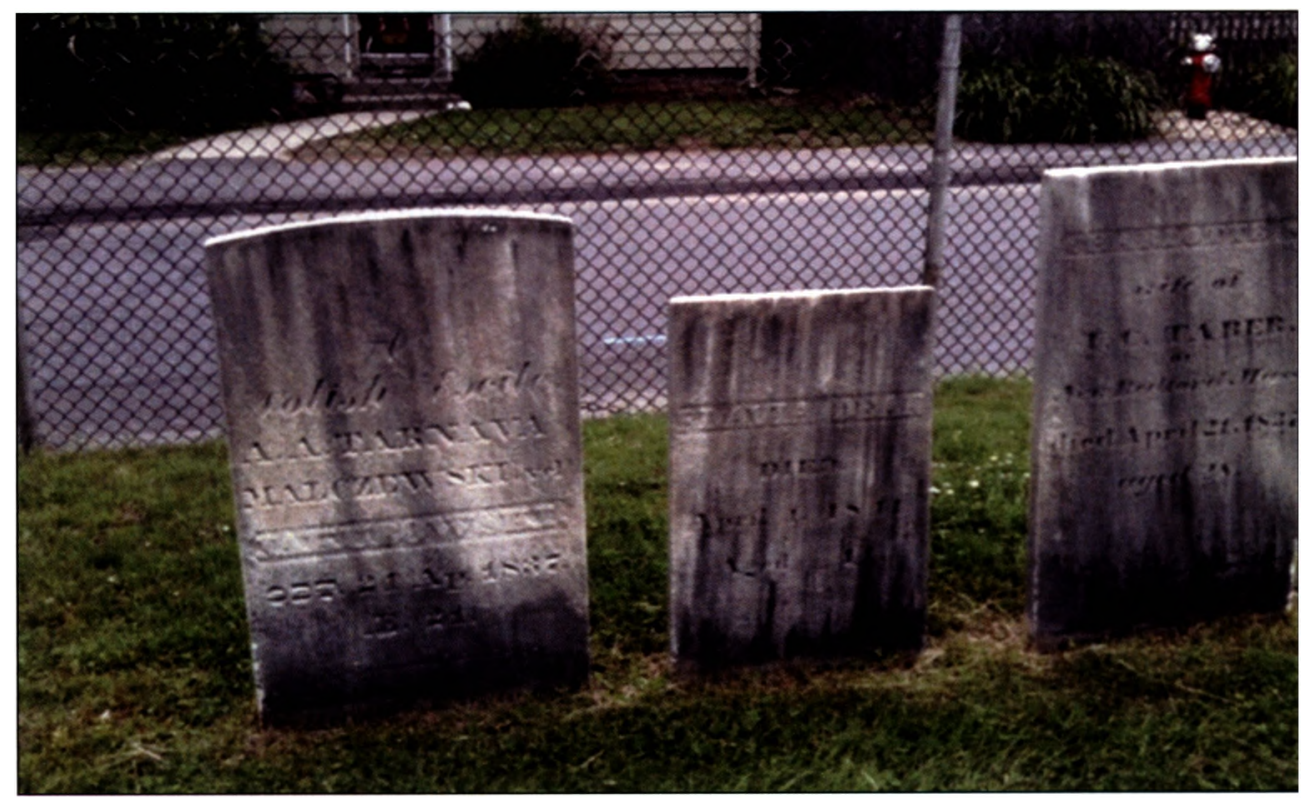

8. Zdjęcic nagrobka Augusta Antoniego Jakubowskiego w kwaterze „Town Lot” w Brigde Strect Cemetery w Northampton wykonane przez Przemysława Jana Blocha 


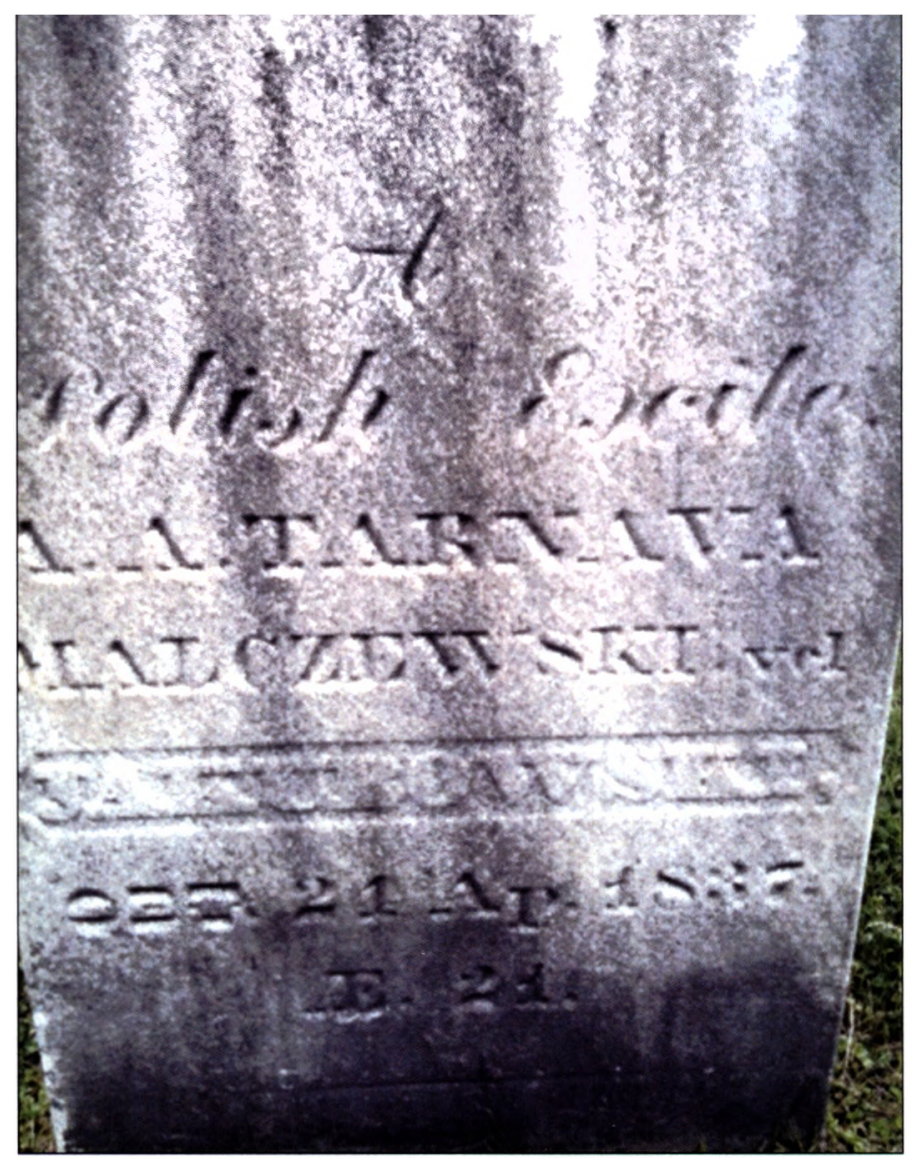

9. Fotografia epitafium nagrobnego Augusta Antoniego Jakubowskiego autorstwa Przemysława Jana Blocha 


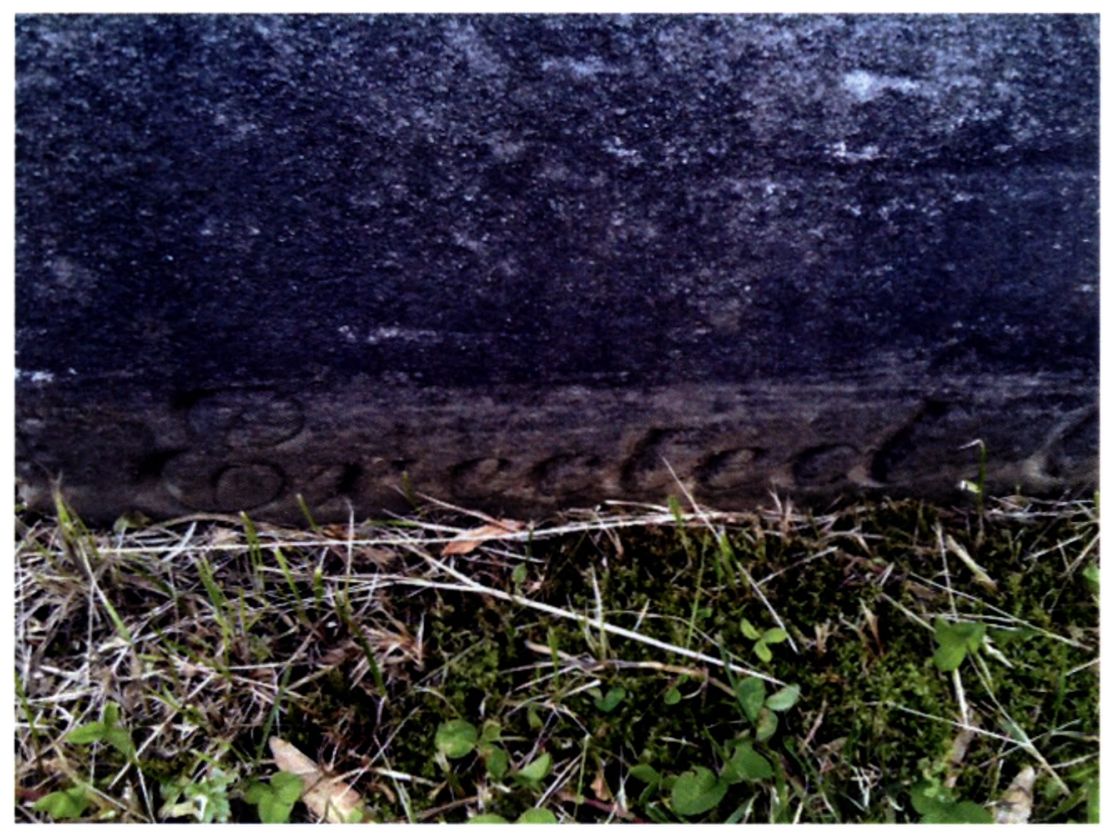

10. Zdjęcie przedstawiające ostatni wers epitafium nagrobnego Jakubowskiego: „Erected by his pupils", wykonane przez Przemysława Jana Blocha 

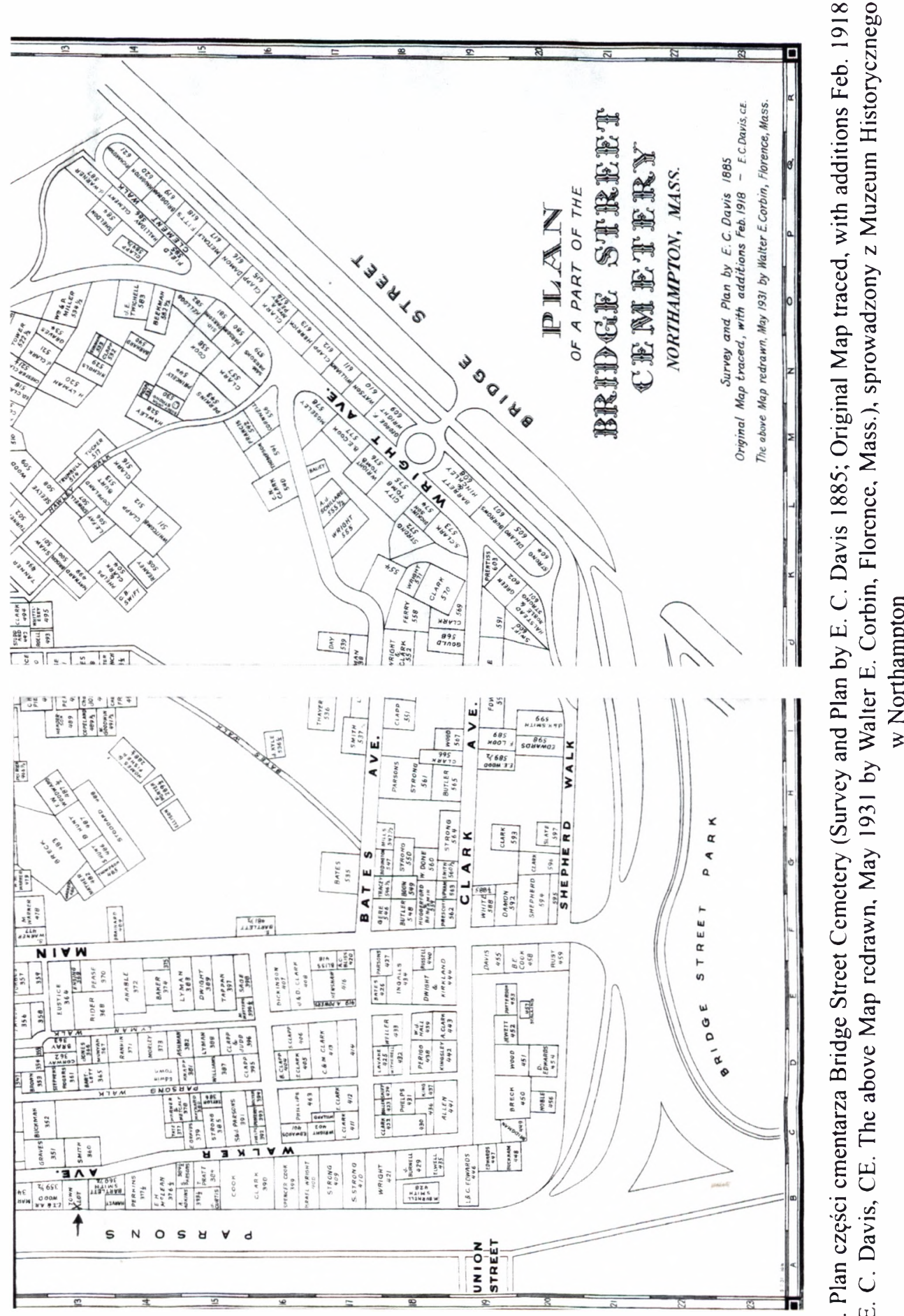

든들

믄

일 3

ते

密

䨔

है

谉

¿

क

은

(5)

ำ

宽告

हี

$\overline{\mathrm{S}}$

ปู

可 


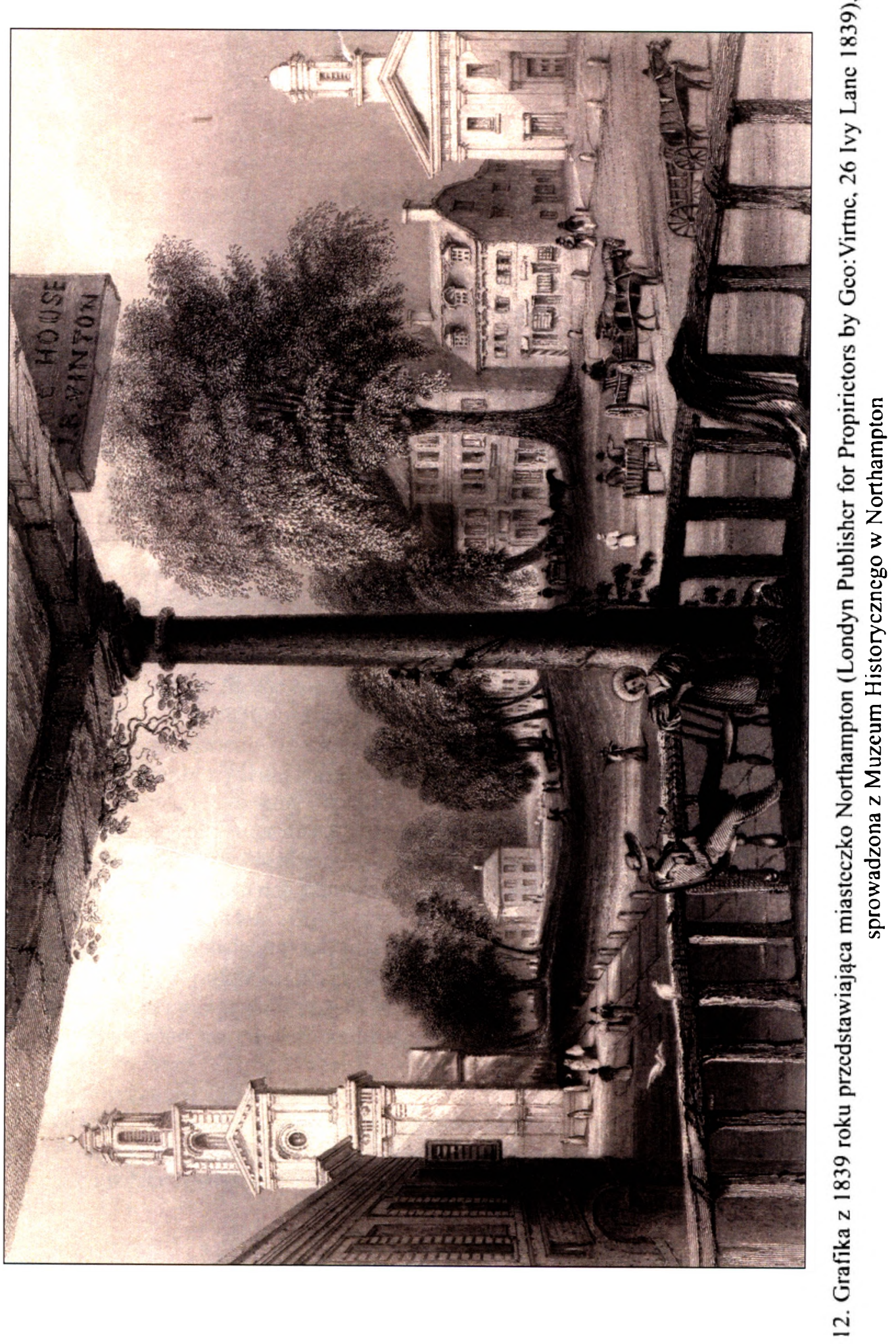





\section{Spis ilustracji}

1. The Remembrances of a Polish Exile w edycji Adama Waldiego (Philadelphia 1835) z kolekcji Fundacji Rodzinnej Blochów. Wewnątrz tego egzemplarza znajduje się dedykacja dla Lucy E. Dewey oraz wiersz Podolia's Exiled Child Julii Bowers.

2. Dedykacja adresowana do Lucy E. Dewey przez Napoleona Kościałkowskiego na kartach egzemplarza The Remembrances of a Polish Exile w edycji Waldiego (Philadelphia 1835).

3. Wiersz Julii Bowers poświęcony pamięci Jakubowskiego, zatytułowany Podolia's Exiled Child, wklejony na okładce The Remembrances of a Polish Exile z edycji Waldiego (Philadelphia 1835).

4. Dwa egzemplarze The Remembrances of a Polish Exile z prestiżowego wydania Colgera Shermana w dwóch wariantach okładek (Philadelphia: Albany 1835), pochodzące z kolekcji Fundacji Rodzinnej Blochów.

5. Okładka The Remembrances of $a$ Polish Exile z edycji Haswell and Fleu (Philadelphia: Albany 1836) z kolekcji Fundacji Rodzinnej Blochów.

6. Strona tytułowa The Remembrances of a Polish Exile z edycji Haswell and Fleu (Philadelphia: Albany 1836) ze zbiorów Fundacji Rodzinnej Blochów.

7. Ostatnie wznowienie The Remembrances of a Polish Exile za życia Jakubowskiego (Dwa warianty wydania Haswell and Fleu Printers, Philadelphia: Albany 1836) z kolekcji Fundacji Rodzinnej Blochów.

8. Zdjęcie nagrobka Augusta Antoniego Jakubowskiego w kwaterze „Town Lot” w Brigde Street Cemetery w Northampton wykonane przez Przemysława Jana Blocha.

9. Fotografia epitafium nagrobnego Augusta Antoniego Jakubowskiego autorstwa Przemysława Jana Blocha.

10. Zdjęcie przedstawiające ostatni wers epitafium nagrobnego Jakubowskiego: „Erected by his pupils", wykonane przez Przemysława Jana Blocha.

11. Plan części cmentarza Bridge Street Cemetery (Survey and Plan by E. C. Davis 1885; Original Map traced, with additions Feb. 1918 - E. C. Davis, CE. The above Map redrawn, May 1931 by Walter E. Corbin, Florence, Mass.), sprowadzony z Muzeum Historycznego w Northampton.

12. Grafika $z 1839$ roku przedstawiająca miasteczko Northampton (Londyn Publisher for Propirietors by Geo: Virtne, 26 Ivy Lane 1839), sprowadzona z Muzeum Historycznego w Northampton. 



\section{Summary}

This book is the first monograph on the works of August Antoni Jakubowski, the son born out of wedlock of Antoni Malczewski. It was based on source materials, that include the copy of the manuscript of Posthumous Letters of the poet, in drawing Marcin Rosienkiewicz up, imported by the author of this book from Polish Library in Paris. This work is an effect of conducted examinations both in Poland, as well as in the USA, where Jakubowski spent final years of his tragic life, ended with the suicide at the age of twenty-one. Reaching to many unknown until now information concerning the life and the works of the author of the first published in the USA book about Polish history, literature and the culture, written in English, was possible thanks to the help of lawyer Przemysław Jan Bloch, the founder of the Blochs Foundation dealing with the restitution of objects associated with the Polish national legacy, lost after the first partition of Poland.

As a result of conducted researches the unknown so far facts from the life of Jakubowski, as well as unpublished works of the writer, as Major Alexander were brought to light. This work begins with discussing the state of the current research on the artistic work and the biography of Jakubowski what constitutes the attempt to put together both Polish and foreign sources about the son of Malczewski. The author of this book systematized the poetic oeuvre of the writer, discussed not-analysed earlier poems by Jakubowski: It is weary and The Exile's Song.

Malczewski's son's poetry was collected in 1839 and prepared to publish by Marcin Rosienkiewicz, who was also an exile and August's companion. However, the poetry was stored in the archives of the Polish Library in Paris for 132 years. In 1971 Julian Maślanka found it and, in 1973, published it. It has not also lived to see its monograph. It's about time that Jakubowski returned from exile and took place due to him in the history of literature. 



\section{Indeks osobowy}

W indeksie pominięto haslo: „Jakubowski August Antoni” i „August Antoni [Jakubowski]”

Aleksander I Romanow 89, 104

Andrzejewski Jerzy 15

Asnyk Adam 56

August III Sas 120, 126

Bachelard Gaston 56, 64, 118-119

Bachórz Józef 124

Baczyński Krzysztof Kamil 50

Bartoszewicz Antonina 125, 129

Bartoszyński Kazimierz 117

Batory Stefan 103

Beniowski Maurycy 57

Bentkowski Feliks 88, 102-103

Beydale Cecylia 32

Białkowski Leopold 28

Bielaski Aleksander 112

Bielecki Robert 27

Bielowski August 74, 98

Bloch Przemyslaw Jan 8, 11, 18, 22-23, 26-28, $44,69,71,77-79,112,132,137,139$

Bloński Jan 119

Borkowski Karol 28

Bowers Henry G. 77

Bowers Russell Julia 9, 24, 77-80, 137

Bowring John 41, 81-82, 88

Bridgman Thomas 44

Brzozowski Jacek 97

Burczyńska Wiktoria Ewa 28

Burdziej Bogdan 75

Burton William Evans 23

Byron George 21, 50, 127-128

Calderón de la Barca Pedro 100

Cedro Adam 16-17

Chłopicki Edward 97

Chmielnicki Bohdan Zenobi 105-106

Chmielowski Piotr 86
Chudak Henryk 119

Cieszkowski August 75

Coleman Arthur 15

Coleman Marion 15

Colemanowie 33

Coxci Michael 121

Czartoryska Izabela 32

Czartoryski Adam Jerzy 41, 103

Czartoryski Konstanty Adam 32, 91, 111, 113, 126

Czacki Tadeusz 21, 103-104

Czarniecki Stefan 61

Czerwiński Edward Joseph 16

Danilewicz-Zielińska Maria 15

Demostenes 103

Dernałowicz Maria 16, 30-31, 36, 42

Dessaix Joseph Marie 117, 126

Dewey Lucy 8, 23-24, 26, 77-78, 137

Dębicki Zbigniew 33, 36

Dmochowski Franciszek Ksawery 89

Dopart Boguslaw 7, 10, 15, 93, 121, 132

Dwernicki Józef 27

Dwight Charles 33

Dwight Margarette 18-19, 21, 42

Elizabeth Buckminster 33

English Thomas Dunn 22-23

Estreicher Karol 33, 44

Ezop 14, 21, 43

Feliński Alojzy 42, 89, 100, 124

Fellini Federico 59

Flisiński W. S. 26

Gacowa Halina 29-31, 36

Gallatin Albert 111 
Gaszyński Konstanty 30, 36

Gawroński Leon 23

Gerard Antoni 111

Giergielewicz Mieczysław 15, 41, 69

Golicyn Aleksander Siergiejewicz 42

Gomulicki Wiktor 36, 75

Gonta Iwan 119-121, 123, 126

Gosławski Maurycy 22, 62, 83, 102

Goszczyński Seweryn 7, 12, 22, 26, 49, 54, 56,

94, 99-101, 103, 105-106, 125

Górski Artur 96

Grabowski Michal 98-99, 121

Grzeloński Bogdan 40

Haiman Mieczyslaw 17, 111

Halkiewicz-Sojak Grażyna 75

Hauman Edward 42, 44

Heemskerck Marten van 121

Hertz Pawel 89

Horacy 87, 89-90

Horodyński Józef 41

Howe Samuel G. 111

Hull Agrippa 33, 112

Iwaszkiewicz Jarosław 15-16, 29, 49

Jablonowski 30

Jackson Andrew 40

Jakubowska Julia 28, 30

Jakubowski Michał 28-29

Jan z Czarnolasu zob. Kochanowski Jan

Janion Maria 128

Januszewski Teofil 31

Januszkiewicz Eustachy 20, 41, 98, 115

Jasińska Maria 126

Jeglińska Elwira 16

Juźwikiewicz Julian 39, 41, 111

Karpiński Franciszek 89-91

Katarzyna II Wielka 103, 106

Kawyn Stefan 95, 101

Kierkegaard Søren Aabye 68

Kleist Heinrich von 43, 66, 68

Klonowic Sebastian Fabian 88

Kochanowski Jan 87-89, 100, 103, 113

Konarski Stanislaw 103, 113, 126

Konarzewski Wojciech 111

Kopernik Mikołaj 102

Korsak Julian 22, 102

Korzeniowski Józef 86, 89, 98, 101, 124-125

Kościałkowski vel Kościołowski Napoleon 8, 13 -

$-14,18,45,77-78,137$

Kościuszko Tadeusz 33, 84, 91, 103, 110
Kowalczykowa Alina 15, 124

Kowalska Alina 81

Kowalski Franciszek 17

Kozieradzki Aleksander 17

Kozieradzki Antoni 98, 101

Koźmian Andrzej Edward 94

Kraitsir Karol 111

Krasicki Ignacy 89-90, 124

Krasiński Zygmunt 18, 89

Kraszewski Józef Ignacy 111, 117, 125

Kridl Manfred 128

Krosnowski Adolf 12

Krzyżanowski Julian 13, 16-17, 45, 83, 96, 103 , 110

Kunaszowski Onufry Hieronim 44

Lacki Aleksander Teodor 51

Lamartine 52

Lathrop Suzanna 24

Lelewel Joachim 97, 105

Lepszy Kazimierz 28

Lerski Jerzy 17, 42

Lincoln Abraham 18

Linde Samuel 124

Longfellow Henry Wadsworth 58

Lubomirska Franciszka Maria z domu Załuska 10, 29-31

Lubomirski Fryderyk 29

Lubomirski Henryk 30

Lyszczyna Jacek 62

Lawski Jarosław 10, 16, 46, 49-50, 54, 61, 63-64, $66-68,73,75,107,114,118,131$

Łepkowski Numa 44, 112

Machowski Wawrzyniec 37

Maciejewski Jaroslaw 29

Makowska Urszula 50

Makowski Stanisław 50

Malczewski Antoni 7, 10, 12, 15, 20-22, 29-33, 36-37, 45-46, 49, 62-65, 92-93, 98-99, 109, $113,118-120,123$

Malczewski Konstanty 42-44

Maślanka Julian 7-8, 10, 13-18, 22, 26, 28, 32$33,36-37,45,48-50,52,57-58,61,68,116$, 123,139

Mickiewicz Adam 20-22, 37, 50-51, 62, 67, 82, 88-92, 94, 96-102, 105, 107, 109, 119, 121, 125

Mieczkowski Domicjan 17

Minakowski Marek Jerzy 29

Minasowicz Józef Dionizy 50

Mochnacki Maurycy 89, 92, 95, 98, 
Modrzewski Andrzej Frycz 103

Morsztyn Zbigniew 51

Nabielak Ludwik 97-98

Naruszewicz Adam 89-90, 113

Nehring Whadyslaw 99

Nesteruk Małgorzata 50

Niemcewicz Julian Ursyn 41, 47-48, 52, 57, 74, 89, 91-92, 111-113, 115, 126

Norwid Cyprian Kamil 17, 75

Novasky Edward de 22, 112

Nowosilcow Nikolaj Nikolajewicz 54, 86, 96

Oczko Piotr 16, 111, 114

Odyniec Edward Antoni 50

Oladowski Hipolit 42

Olizar Gustaw 17

Orzechowski Stanislaw 103, 113

Osiński Alojzy 101

Osjan 63

Ossendowski Antoni Ferdynand 59

Parys Ignacy 20

Pauszer-Klonowska Gabriela 32

Peabody William Bourne Oliver 82

Petrarka Francesco 95

Pierce-Poor Mary 24, 77, 112

Pigoń Stanislaw 12-13, 17, 35, 45, 89

Piotrowski Wojciech 16

Platon 122

Poczobutt-Odlanicki Marcin 103

Poe Edgar Allan 22

Polanowski Tadeusz 15

Poniatowski Stanislaw August 89

Potoccy 104

Potocka Klaudia 115

Potocki Franciszek Salezy 121

Potrykowski Józef Alfons 12

Pułaski Kazimierz 84, 106

Rasyn (wl. Racine Jean Baptiste) 12

Rand Nancy T. 24

Rej Mikolaj 88

Rolle Antoni 30

Rolle Michał 124

Ramorino Girolamo 107

Rosienkiewicz Marcin 7, 9-11, 13-14, 17-18, 20 , $22,27-28,32,36-38,40-41,43,45-49,53$, $61-62,66,73,81-82,85,87,94,98,101,111$, $115-116,118-119,125,139$

Rostowski 41

Rucińska Zofia 45
Rutkowski Ewa 116

Rydygier Fiodor 107

Rzewuski Kazimierz 32

Rzewuski Waclaw 95

Sawicki Stefan 102

Scott Walter 18

Sedgwick Charles 33

Sedgwick Dwight 33

Sedgwick Theodor 33

Sherman Colger 13, 21, 77, 111, 113, 137

Siemieński Lucjan 31-32

Słowacki Juliusz 50, 66, 98, 118, 128

Smith John Jay 112

Sobolewski Paweł 13-14, 17, 22, 27, 35-37, 40, $42-44,85$

Sokołowski Mikołaj 73

Sprague William Buell 7, 9, 13-14, 17-19, 22, 27, $29,32,35,39,41-42,44,81,83-85,87,112$

Stadnicki Konstanty 107

Stasik Florian 76

Stebbins Lathrop Clarissa 24, 26, 77

Stefanowska Zofia 89

Strzyżewski Mirosław 89

Szekspir William 21, 100-101

Szturc Włodzimierz 121-122

Szymanowski Józef Maciej Ignacy 89

Szymonowic Szymon 88

Szyrma Lach Krystyn 73, 81-82, 88

Sniadecki Jan 102

Sniadeccy 103

Tatarkiewicz Władyslaw 119

Trembecki Stanislaw 59, 89

Turowski Kazimierz Józef 29

Tutinas Jolanta 15

Tuwim Julian 54, 62

Tyszyński Aleksander 92, 123

Ujejski Józef 30

De Vega Lope (wł. de Vega y Carpio Félix Lope) 100

Waldie Adam 21, 111-113, 137

Wardziński Zygmunt 16

Waszyngton George 91, 106

Węgierski Tomasz Kajetan 57

Wierzbicki Feliks Pawel 26

Wiesolowski Franciszek 28

Winter Nevin Otto 74 
Witkowska Alina 15, 49, 118, 131

Witwicki Stefan 90, 98

Wolter (Arouet François-Marie) 90, 126

Wójcicki Kazimierz Władysław 42

Wyka Kazimierz 50

Wyspiański Stanisław 57

Zabłocki Franciszek 100

Zaborowski Tymon 83

Zaleski Bohdan 62, 89, 97-100

Zaliw'ski Józef 28, 39, 53, 98, 107, 110

Załuscy 31-32, 104
Załuski Józef 29

Załuski Karol 30, 32, 36

Zan Tomasz 50, 96

Zgorzelski Czesław 107

Zimnoch S. Frederick 114

Ziołowicz Agnieszka 15

Żeleźniak Maksym 121

Żmigrodzka Maria 93

Źółkiewski Stanisław 106

Żuk Eugeniusz 16, 20, 82-83, 96-98, 101, 108, 110 

Dotychczas nie było nie tylko monograficznego obrazu życia i twórczości Augusta Antoniego Jakubowskiego, lecz brakowało, w części, podstawowych ustaleń biograficznych, a nawet dostępu do niektórych znanych z tytułu pism syna Malczewskiego (najlepszym przykładem jest urywek powieściowy Major Aleksander). Dzięki swym wytrwałym poszukiwaniom, które sięgnęły Stanów Zjednoczonych i Biblioteki Polskiej w Paryżu; dzięki życzliwości ze strony osób z zagranicy i z kraju, wtajemniczonych w losy Jakubowskiego i jego spuścizny - Ewa Modzelewska stała się posiadaczką największego zbioru tekstów, pamiątek i informacji o tragicznym poecie. Trzeba podkreślić, że wkład Autorki w ową wiedzę jest doprawdy imponujący; domena biograficzna ma w omawianej rozprawie wartość równą dziedzinie interpretacyjnej. Wyjątkowa wartość niniejszej książki wiąże się z przedmiotem badawczym - nieprzeciętnym oeuvre zagadkowego i tragicznego romantyka; i ze stylem pracy Autorki, $\mathrm{z}$ ogromną wytrwałością i inwencją docierającą do nieznanych dokumentów i faktów; i z wszechstronnością jej badawczych możliwości - i wreszcie sumą rezultatów historycznoliterackich, interpretacyjnych, które stały się udziałem Autorki.

Prof. dr hab. Bogusław Dopart

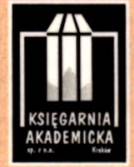

www.akademicka.pl

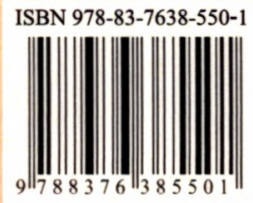

